\title{
Discovery of Roblitinib (FGF401) as a Reversible-Covalent Inhibitor of the Kinase Activity of Fibroblast Growth Factor Receptor 4
}

Robin A. Fairhurst,* Thomas Knoepfel, Nicole Buschmann, Catherine Leblanc, Robert Mah, Milen Todorov, Pierre Nimsgern, Sebastien Ripoche, Michel Niklaus, Nicolas Warin, Van Huy Luu, Mario Madoerin, Jasmin Wirth, Diana Graus-Porta, Andreas Weiss, Michael Kiffe, Markus Wartmann, Jacqueline Kinyamu-Akunda, Dario Sterker, Christelle Stamm, Flavia Adler, Alexandra Buhles, Heiko Schadt, Philippe Couttet, Jutta Blank, Inga Galuba, Jörg Trappe, Johannes Voshol, Nils Ostermann, Chao Zou, Jörg Berghausen, Alberto Del Rio Espinola, Wolfgang Jahnke, Pascal Furet

Novartis Institutes for BioMedical Research, CH-4002 Basel, Switzerland.

\section{Table of contents}

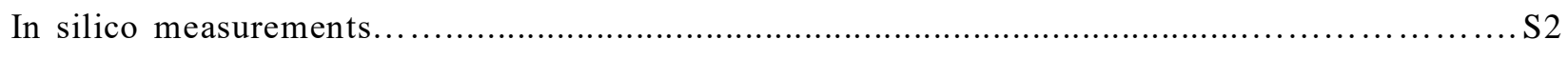

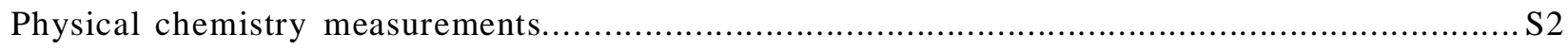

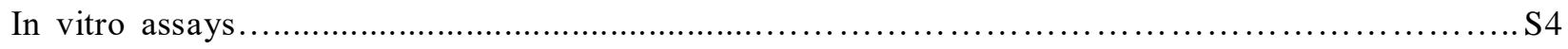

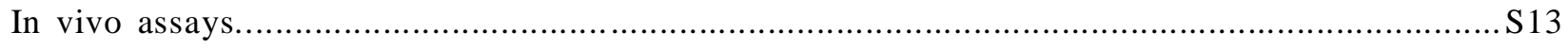

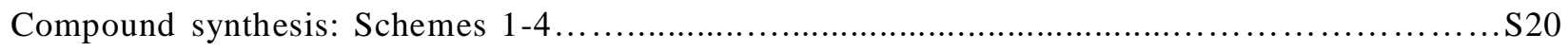

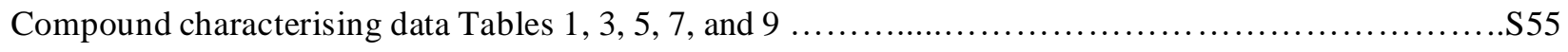

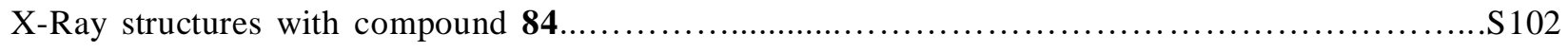

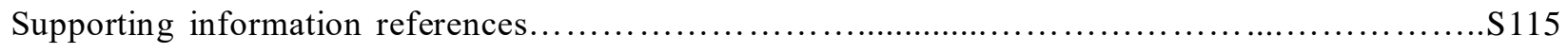


$\underline{\text { In silico measurements }}$

Molecular modeling of the interactions with FGFR4: At the initiation of this project, no crystal structure of the kinase domain of FGFR4 was available. Therefore, to support the project a model of this domain was generated by homology to the crystal structure of infigratinib in complex with FGFR1 (PDB code: 2FGI, see accompanying file). The sequences of the human FGFR1 and FGFR4 kinases were obtained from SWISS-PROT, ${ }^{\mathrm{S} 1}$ entries P11362 and P22455, respectively. The sequences were aligned using T-Coffe. ${ }^{\mathrm{S} 2}$ On the basis of the resulting alignment, the 3D structure of the FGFR4 kinase was modeled using the 'WHAT IF' program with the default parameters (PIRPSQ module, BLDPIR command). ${ }^{\mathrm{S} 3}$ Modeling and docking using the homology model was performed with a version of MacroModel enhanced for graphics by A. Dietrich. ${ }^{\mathrm{S}}$ The compounds were manually constructed and docked in the ATP site of the model and the resulting ligand-protein complexes energy-minimized using the AMBER $* / \mathrm{H}_{2} \mathrm{O} / \mathrm{GBSA}$ force field. The figures for the structural models were prepared using PYMOL (Schrodinger, Inc.).

$\mathrm{Ab}$ initio conformational calculations were performed in Jaguar (Schrödinger Inc.) at the B3LYP/6-31G** level with full geometry optimization. LogP and pKa values were calculated using the Novartis modeling platform FOCUS. ${ }^{\text {S5 }}$ 3D-PSA values were calculated with a newly developed method. ${ }^{\text {S6 }}$

Cross-species sequence allignment: Sequence information for the FGFR4 gene was obtained from internal exome sequencing in cynomolgus monkeys and whole genome sequencing data in Beagle dog, CD1 mouse, Wistar Han and Sprague Dawley rats using customized R scripts. Protein sequences were aligned using AlignX software (Invitrogen VectorNTI v11.5.4).

\section{$\underline{\text { Physical chemistry measurements }}$}

Differential Scanning Calorimetry (DSC): The solid-state of the test compounds were characterised by DSC using a DSC Q2000 (TA Instruments Ltd.) equipped with a refrigerated cooling system (RCS90, TA Instruments). Samples were weighed in duplicate (about 0.2-1.0 mg) in low mass pans (Tzero Low-Mass Pans, TA Instruments) and clamped with lids (Tzero Lids, TA Instruments) using a sample encapsulating press (Tzero press, TA Instruments). The sample and reference pan were then exposed to a linear heating gradient of $10{ }^{\circ} \mathrm{C} / \mathrm{min}$ and $50{ }^{\circ} \mathrm{C} / \mathrm{min}$ from $-40{ }^{\circ} \mathrm{C}$ to $300{ }^{\circ} \mathrm{C}$. The melting point on set temperature $\left({ }^{\circ} \mathrm{C}\right)$ and Heat of fusion $\left(\Delta \mathrm{H}_{\text {fus }}\right.$ in $\left.\mathrm{kJ} / \mathrm{mol}\right)$ were extracted from the thermograms. 
Thermodynamic solubility (shake flask method): Samples were weighted into $2 \mathrm{ml}$ glass vials prior to the addition of pH 6.8 phosphate buffer to obtain a nominal concentration of $2 \mathrm{mg} / \mathrm{ml}$. The samples were sonicated for $5 \mathrm{~min}$ and shaken overnight at $1000 \mathrm{rpm}$ (Titrimax 1000, Heidolph) at room temperature. A first phase separation of supernatant and undissolved solid was performed by centrifugation at $3600 \mathrm{rpm}$ for 15 minutes (Eppendorf Centrifuge 5804). The supernatant was then transferred into a conical glass vial for a second centrifugation. An adequate dilution was made using the particle free supernatant and the concentration quantified by LC-HRMS using a 6 point calibration curve (Vanquish coupled to an Exactive-Plus, Thermo Scientific).

X-ray powder diffraction (XRPD): Crystallinity was assessed by XRPD with a Brucker D8 Discover instrument using $\mathrm{Cu}(1.5418 \AA$ Å) radiation with a Goebel mirror-Cu Microslit-10 (1 mm height) and UBC-Collimator-G-10 (1 $\mathrm{mm}$ width) optics and a VÅNTEC-500 detector. Scan range $9^{\circ}$ to $36^{\circ}$ (2Ө value), scan time $120 \mathrm{~s}$ ( 2 steps). Compounds described as crystalline produced diffraction patterns consistent with a high level of crystallinity.

Potentiometric titration: Lipophilicity (with 1-octanol) and ionisation constants were measured by potentiometric titration using a Sirius T3 instrument.

NMR study with 18: In order to investigate the equilibrium of the aldehyde and hydrated species, $50 \mu \mathrm{M}{ }^{13} \mathrm{C}$ labeled analogue 18 was dissolved in phosphate-buffered saline (PBS) and ${ }^{1} \mathrm{H}$ as well as ${ }^{1} \mathrm{H},{ }^{13} \mathrm{C}-\mathrm{HSQC}$ experiments were recorded an a Bruker AV600 NMR spectrometer operating at $600 \mathrm{MHz}$ proton frequency at $23{ }^{\circ} \mathrm{C}$. Once the identity of the hydrated species was confirmed by HSQC, the 1-dimensional ${ }^{1} \mathrm{H}$ spectrum was used for quantification.

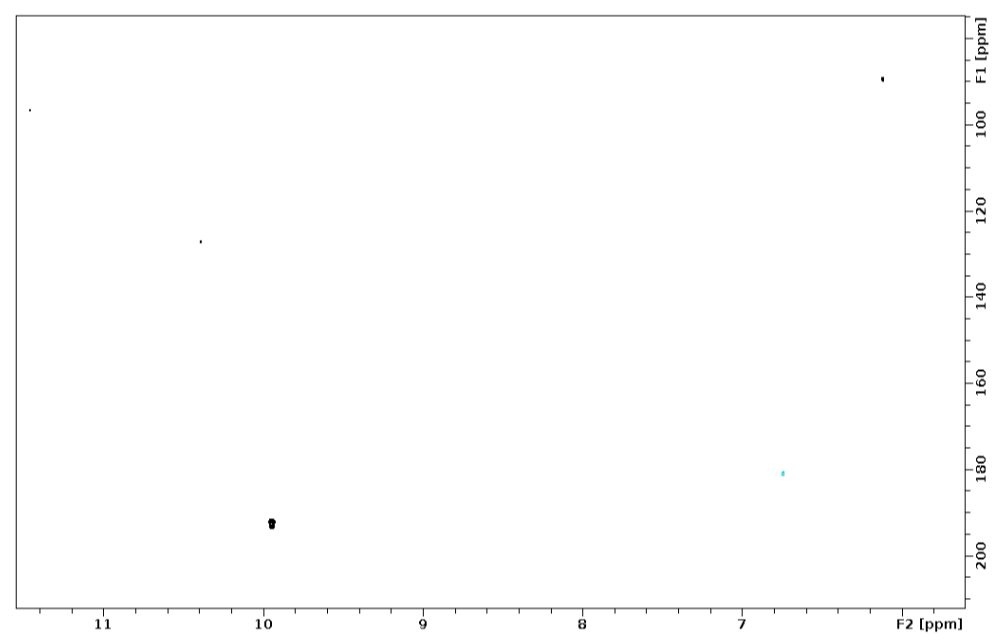

$\left[{ }^{1} \mathrm{H},{ }^{13} \mathrm{C}\right]$ HSQC spectra of $\mathbf{1 8}$ 
$\underline{\text { In vitro assays }}$

Biochemical and cellular assays: FGFR biochemical assays were performed as previously described in reference 19 from the main text. Biochemical assays with the N535K and V550E mutated FGFR4 kinase domains (442 -753) were carried out in an analagous manner to the corresponding wild-type non-phosphorylated protein.

Binding kinetics with the FGFR4 kinase domain were measured by Proteros biostructures GmbH as described in reference 40 from the main text.

Experiments starting with non-phosphorylated FGFR4 and with varying ATP preincubation times prior to the inhibition of the inhibitor were carried out as described in reference 40 from the main text.

The inhibition of FGFR4 autophosphorylation in BaF3 cells (pFGFR4) was measured as described in reference 40 from the main text.

Proliferation assays in $\mathrm{BaF} 3$ and $\mathrm{HCC}$ cell lines were carried out described in reference 51 from the main text.

SILAC experiments to measure the resynthesis rates of FGFR4 in the HCC cell lines were carried out as described in reference 19 from the main text.

$\underline{\text { In vitro metabolic stability assays }}$

Liver microsome incubations: Liver microsome incubations use commercially available liver microsomes from various species, most commonly mouse, rat, dog, cynomolgus monkey, and/or human. Liver microsomes are mixed with alamethicin, UDPGA, test compound, GSH/NAC (where applicable) and phosphate buffer at $0{ }^{\circ} \mathrm{C}$ to a to tal volume of $450 \mu \mathrm{L}$, with concentrations for each sample given in the table below. The reaction mixture is preincubated for $3 \mathrm{~min}$ at $37{ }^{\circ} \mathrm{C}$ then NADPH-regenerating system $(50 \mu \mathrm{L})$ is added to start the reaction. After $60 \mathrm{~min}$ at $37{ }^{\circ} \mathrm{C}$, the reaction is stopped with $500 \mu \mathrm{L}$ acetonitrile $\left(0^{\circ} \mathrm{C}\right)$, an internal standard is added $(10 \mu \mathrm{L}$, final concentration $2.5 \mu \mathrm{M}$ ), and the reaction mixture is stored at $-80{ }^{\circ} \mathrm{C}$. For $0 \mathrm{~min}$ controls, the acetonitrile is added before the NADPH-regenerating system. 
Final set-up of incubations of test compounds with liver microsomes:

\begin{tabular}{|c|c|c|c|c|c|c|c|}
\hline & \multicolumn{7}{|c|}{ Sample } \\
\hline & $\begin{array}{c}\text { Control } \\
1 \\
\end{array}$ & $\begin{array}{c}\text { Control } \\
2 \\
\end{array}$ & $\begin{array}{c}\text { Control } \\
3 \\
\end{array}$ & $\begin{array}{c}\text { Control } \\
4\end{array}$ & Test & $\begin{array}{c}\text { GSH } \\
\text { trapping }\end{array}$ & $\begin{array}{c}\text { NAC } \\
\text { trapping }\end{array}$ \\
\hline Microsomes (mg/mL protein) & 0 & 0 & 0.3 & 0.3 & 0.3 & 0.3 & 0.3 \\
\hline Phosphate buffer, pH 7.4 (mM) & 100 & 100 & 100 & 100 & 100 & 100 & 100 \\
\hline Alamethicin $(\mu \mathrm{M})$ & 1.25 & 1.25 & 1.25 & 1.25 & 1.25 & 1.25 & 1.25 \\
\hline UDPGA (mM) & 2.4 & 2.4 & 2.4 & 2.4 & 2.4 & 2.4 & 2.4 \\
\hline $\mathrm{GSH}^{*}(\mathrm{mM})$ & 1.5 & 1.5 & 0 & 1.5 & 0 & 1.5 & 0 \\
\hline $\mathrm{NAC}^{*}(\mathrm{mM})$ & 0 & 0 & 0 & 1.5 & 0 & 0 & 1.5 \\
\hline Test compound $(\mu \mathrm{M})$ & 5 & 5 & 5 & 5 & 5 & 5 & 5 \\
\hline NADPH-Reg-System** $(\mu \mathrm{L})$ & 0 & 50 & 50 & 50 & 50 & 50 & 50 \\
\hline Incubation time (min) & 60 & 60 & 0 & 0 & 60 & 60 & 60 \\
\hline
\end{tabular}

*A 1:1 mixture of GSH/[ ${ }^{13} \mathrm{C}_{2}-{ }^{15} \mathrm{~N}$-Glycine]-GSH and/or $N$-acetylcysteine/ $d_{3}-N$-acetylcysteine is used.

**Stock solution concentrations: isocitrate-dehydrogenase $(10 \mathrm{U} / \mathrm{mL})$, NADP $(10 \mathrm{mM})$, isocitrate $(50 \mathrm{mM})$ and $\mathrm{MgCl}_{2}(50 \mathrm{mM})$.

Hepatocyte incubations: All experiments are carried out using Williams medium E supplemented with fetal bovine serum $(10 \%)$. Stock solutions of test compounds $(2 \mathrm{mM})$ are prepared in DMSO. Cryopreserved hepatocytes are obtained from commercial sources and stored under liquid nitrogen until used. Before use, the cells are thawed rapidly in a $37^{\circ} \mathrm{C}$ water bath for up to $2 \mathrm{~min}$, then transferred to a tube containing incubation medium (40 $\mathrm{mL}, 37$ ${ }^{\circ} \mathrm{C}$ ). The suspension is centrifuged for 1 minute at $50 \mathrm{x} \mathrm{g}$, and then the supernatant is removed and discarded. The cell pellet is re-suspended by gentle agitation in a small volume (2-5 mL) of incubation medium. An aliquot of cell suspension $(50 \mu \mathrm{L})$ is mixed with trypan blue $(50 \mu \mathrm{L})$ for viability assessment and cell counting. An appropriate volume of incubation medium is then added to the remaining cell suspension to give a final concentration $1 \times 10^{6}$ cells/mL. Cell suspension ( $1 \mathrm{~mL}$ ) is transferred to wells of a 12 well plate, and test compound solution is added (10 $\mu \mathrm{M}$ final concentration). The samples are then incubated at $37{ }^{\circ} \mathrm{C}$ under an atmosphere of $75 \% \mathrm{O}_{2}, 5 \% \mathrm{CO}_{2}, 20 \%$ $\mathrm{N}_{2} ; 98 \%$ humidity with shaking (50 rpm) in a HERAcell 240i incubator (Thermo Fischer Scientific, Waltham, MA, USA). At each time point $(0,4,6 \mathrm{~h}), 200 \mu \mathrm{L}$ of incubation sample is added to 1 volume of cold acetonitrile $\left(0{ }^{\circ} \mathrm{C}\right)$, an internal standard is added $(8 \mu \mathrm{L}$, final concentration $5 \mu \mathrm{M})$, and the mixture is frozen at $-80{ }^{\circ} \mathrm{C}$.

In vitro rapid equilibrium dialysis (RED) plasma protein binding assay: Compound stock solution was prepared at $10 \mathrm{mM}$ in DMSO and further diluted to $0.5 \mathrm{mM}$ in DMSO. Quench solutions were prepared by spiking acetonitrile with an analytical internal standard compound (diazepam). Frozen plasma was thawed from $-20{ }^{\circ} \mathrm{C}$ and centrifuged to remove the fibrin clot. The plasma was pre-warmed to $37^{\circ} \mathrm{C}$. 
Summary of the plasma:

\begin{tabular}{|c|c|c|c|c|}
\hline Species & Strain & Supplier & Lot number & Number of donors \\
\hline Human & Homo sapiens & $\begin{array}{l}\text { Sera Lab / } \\
\text { Bioreclamation IVT }\end{array}$ & BRH332572 & $\begin{array}{l}20 \text { ( } 10 \text { males and } 10 \\
\text { females) }\end{array}$ \\
\hline Dog & Beagle & $\begin{array}{l}\text { Sera Lab / } \\
\text { Bioreclamation IVT }\end{array}$ & BGLBREC.42860 & 14 (mixed gender) \\
\hline Rat & Wistar Hannover & $\begin{array}{l}\text { Sera Lab / } \\
\text { Bioreclamation IVT }\end{array}$ & RATBREC.122662 & 1255 (mixed gender) \\
\hline Mouse & CD1 & $\begin{array}{l}\text { Sera Lab / } \\
\text { Bioreclamation IVT }\end{array}$ & MSEBREC.105491 & 2456 (mixed gender) \\
\hline
\end{tabular}

Sodium phosphate dibasic (23 g - Sigma S9390) and potassium phosphate monobasic (2 g - Sigma P5655) were added to water. Potassium chloride solution at $4 \mathrm{M}(668 \mu \mathrm{L}$ - Sigma 60142) and sodium chloride solution at 5M (27.59 $\mathrm{mL}$ - Sigma 71336) were added to that phosphate solution. The pH was adjusted to 7.4 and water was added to obtain a final volume of $1 \mathrm{~L}$. The buffer was stored in the refrigerator at $4{ }^{\circ} \mathrm{C}$ for one month. The RED Teflon base plate (\#89811, Thermo Scientific, Waltham, MA, USA) was soaked in $20 \%$ ethanol for 20 hours and then rinsed twice in deionized water prior to use. RED Device inserts (MWCO 8000 Da, \#89809, Thermo Scientific) were used dry as provided by the supplier and without pre-treatment. The plasma was spiked with test compound to achieve a final nominal concentration of $5 \mu \mathrm{M}$ at a final solvent concentration of $1 \%$ DMSO. The spiked plasma $(300 \mu \mathrm{L})$ in triplicate was added to a plasma chamber of the insert and $500 \mu \mathrm{L}$ of $100 \mathrm{mM}$ phosphate buffer, $\mathrm{pH}$ 7.4 was added into the respective buffer chamber insert. The plate was sealed with a gas permeable adhesive seal (\#AB-0718, Thermo Scientific) and placed on a dynamic shaker (model V 2000, Kisker Biotech, Stein furt, Germany) set at $750 \mathrm{rpm}$. The shaker was placed inside an incubator set at $37{ }^{\circ} \mathrm{C}$ with $5 \% \mathrm{CO}_{2}$ environment and without added humidity. Samples were incubated for $4 \mathrm{~h}$. At the end of the incubation, aliquots from the buffer and plasma chamber were collected and placed in a deep well plate. The buffer and plasma samples were supplemented with the opposite matrix to enable all samples to be matrix-matched. Quench solution (ice cold acetonitrile containing analytical internal standard diazepam) was added and briefly mixed to precipitate proteins, and the deep well plate was centrifuged for $20 \mathrm{~min}$ at $4{ }^{\circ} \mathrm{C}$ and $4500 \mathrm{~g}$. An aliquot of $50 \mu \mathrm{l}$ supernatant from each well was transferred to a clean 96-well plate and further diluted with $35 \mu 1$ water to obtain a 1:1 organic-water ratio in the samples. To enable calculation of \% plasma stability and \% recovery, aliquots of compound-spiked plasma (in triplicate) were directly transferred at time zero to a 96 deep well plate and quenched immediately following matrix matching. In parallel, aliquots of compound-spiked plasma were incubated in a 96-well Teflon plate at $37{ }^{\circ} \mathrm{C}(750$ $\mathrm{rpm}$ ) for $4 \mathrm{~h}$. Subsequently the samples were matrix-matched, quenched and processed. Peak area ratios (PAR) of analyte:internal standard were measured via LC-MS/MS. 
In vitro plasma stability assay: The stability of drug candidates is measured in pooled plasma (once thawed, K3 EDTA anticoagulant) following incubation at $37{ }^{\circ} \mathrm{C}$ under constant shaking (100 rpm) and analysis using an LC- MS/MS based compound depletion approach. The method is automated onto a robotic liquid-handling platform. The assay conditions are as follows:

\begin{tabular}{ll}
\hline Compound concentration & $1 \mu \mathrm{M}$ \\
Plasma concentration & $50 \%$ in Dulbeccos phosphate buffered saline \\
Plasma type & Pooled K3 EDTA \\
Plasma pH adjustment & None (only once thawed plasma used) \\
Species & Mouse, Rat, Dog, Monkey and Human (all pooled by species) \\
Strain & CD-1 / Sprague Dawley / Beagle / Cynomolgous \\
Gender & all mixed gender \\
Timepoints $(\mathrm{n}=1)$ & $0,5,15,30,60,120$ minutes \\
Incubation condition & $37^{\circ} \mathrm{C}$, atmospheric air, 100rpm Incubation \\
Controls & Benfluorex + Camostat (pooled) \\
Robotic liquid-handling platform & Hamilton Microlab Star \\
\hline
\end{tabular}

Compound stock solution was prepared at $10 \mathrm{mM}$ in DMSO. Quench solutions were prepared by spiking acetonitrile with an analytical internal standard compound (glyburide at $0.2 \mu \mathrm{M}$ ). Frozen plasma was thawed from $-20{ }^{\circ} \mathrm{C}$ and centrifuged to remove the fibrin clot. The plasma was pre-warmed to $37^{\circ} \mathrm{C}$.

A summary of the plasma used is presented here:

\begin{tabular}{|c|c|c|c|c|}
\hline Species & Strain & Supplier & Lot number & Number of donors \\
\hline Human & Homo sapiens & $\begin{array}{l}\text { Sera Lab / } \\
\text { Bioreclamation IVT }\end{array}$ & BRH332572 & $\begin{array}{l}20 \text { ( } 10 \text { males and } 10 \\
\text { females) }\end{array}$ \\
\hline Monkey & Cynomolgous & $\begin{array}{l}\text { Sera Lab / } \\
\text { Bioreclamation IVT }\end{array}$ & CYNBREC.79684 & 32 (mixed gender) \\
\hline Dog & Beagle & $\begin{array}{l}\text { Sera Lab / } \\
\text { Bioreclamation IVT }\end{array}$ & BGLBREC.42860 & 14 (mixed gender) \\
\hline Rat & Wistar Hannover & $\begin{array}{l}\text { Sera Lab / } \\
\text { Bioreclamation IVT }\end{array}$ & RATBREC. 122662 & 1255 (mixed gender) \\
\hline Mouse & CD1 & $\begin{array}{l}\text { Sera Lab / } \\
\text { Bioreclamation IVT }\end{array}$ & MSEBREC. 105491 & 2456 (mixed gender) \\
\hline
\end{tabular}

The compounds are incubated at a final assay concentration of $1 \mu \mathrm{M}$ in plasma at $37{ }^{\circ} \mathrm{C}$ with shaking (100 rpm). Serial samples of plasma incubates are taken over a pre-defined incubation time course $(0,5,15,30,60$ and 120 min). The samples are quenched and precipitated by addition of ice cold acetonitrile containing internal standard $(0.2 \mu \mathrm{M}$ glyburide) followed by centrifugation. The parent compound in the supernatants is then analyzed by LC MS/MS. Stability is determined semi-quantitatively from peak area ratios (PAR) of analyte:internal standard which is used to determine the percentage stability at pre-defined timepoints in relation to a zero minute timepoint.

The percentage stability of a compound in plasma at time $t$ is calculated as detailed in Equation 1: 
The stability data is transformed using a non-linear regression (XLfit model "Exp/Log 500") and plotted against time points to defined the initial phase of the slope (or initial rate of elimination kel).

The half-life of each compound in plasma is calculated using the Equation 2:

Half-life $(\min )=(\operatorname{LN}(2)) /$ kel $\quad$ Equation 2

Assessment of restrictive protein-binding in human plasma with the dextran-coated charcoal (DCC) method: A stock solution was prepared at $10 \mathrm{mM}$ in DMSO and further diluted to the concentration of $0.2 \mathrm{mM}$ in methanol. The quench solution was prepared by spiking acetonitrile with glyburide (analytical internal standard) at a final concentration of $0.2 \mu \mathrm{M}$. Frozen plasma (Homo sapiens, Bioreclamation IVT, Lot number HMN40525, 10 females, 10 male donors) was thawed from $-20{ }^{\circ} \mathrm{C}$ and centrifuged to remove the fibrin clot. The plasma was pre-warmed at $37{ }^{\circ} \mathrm{C}$. Sodium phosphate dibasic (23 g - Sigma S9390) and potassium phosphate monobasic (2 g - Sigma P5655) were added to water. Potassium chloride solution at 4M (668 $\mu \mathrm{L}$ - Sigma 60142) and sodium chloride solution at $5 \mathrm{M}(27.59 \mathrm{~mL}$ - Sigma 71336) were added to that phosphate solution. The pH was adjusted to 7.4 and water was added to obtain a final volume of $1 \mathrm{~L}$. The buffer was stored in the refrigerator at $4{ }^{\circ} \mathrm{C}$ for one month.

The DCC method for was used for evaluation of the dissociation rate of 24 from plasma proteins. The compounds Propranolol and Warfarin were used respectively as permissive and restrictive controls respectively in order to demonstrate the suitability of the DCC method. The dextran-coated charcoal solution was prepared by washing 2 $\mathrm{g}$ of activated charcoal three times by vigorous mixing in $50 \mathrm{~mL}$ HPLC grade water filtered at $0.2 \mu \mathrm{M}$ (VWR reference 83645.320). After each wash step, the charcoal was pelleted at $1200 \mathrm{~g}$ for 10 minutes and the supernatants were discarded. After washing, the charcoal was resuspended in $25 \mathrm{~mL}$ of $100 \mathrm{mM}$ phosphate buffer at pH 7.4 containing $0.2 \mathrm{~g}$ of dextran giving a final DCC suspension of $80 \mathrm{mg} / \mathrm{mL}$. $200 \mu \mathrm{L}$ of plasma spiked with $10 \mu \mathrm{L}$ of the $200 \mu \mathrm{M} 24$, Propranolol or Warfarin solutions were equilibrated for 10 minutes at $37{ }^{\circ} \mathrm{C}$ under shaking (Thermoshaker, $750 \mathrm{rpm}$ ). DCC incubations were started by the addition of one volume of DCC solution to prewarmed spiked plasma and were incubated at $37{ }^{\circ} \mathrm{C}$, shaking $(750 \mathrm{rpm})$ for $60,30,10,5,3$, and $1 \mathrm{~min}$. The incubations were initiated in reverse order (longest incubation first) in order to stop them all simultaneously. The 0-minute time-point samples were incubated with phosphate buffer and DCC only. At the end of the incubations, the charcoal was pelleted by centrifugation at $4500 \mathrm{~g}$ for 5 minutes at $4{ }^{\circ} \mathrm{C}$. An aliquot was taken from the supernatant and quenched into 6 volumes of acetonitrile containing the internal standard (IS) and centrifuged at 
$4500 \mathrm{~g}$ for 25 minutes at $4{ }^{\circ} \mathrm{C}$. The supernatants were reconstituted with HPLC grade water filtered at $0.2 \mu \mathrm{M}$ (VWR reference 83645.320) to obtain a 1:1 organic/aqueous ratio and analyzed by LC-MS/MS to measure the percentage of parent compound remaining in the plasma compartment at each time-point in relation to the 0-minute incubation sample defined as $100 \%$. The dissociation rate of the compounds from human plasma proteins was assessed by calculating the percentage of the compounds remaining after incubation with the DCC. The ratio of compound remaining in the supernatant at $\mathrm{t} 0$ and $\mathrm{tX}$ reflects the rate of dissociation of the compounds from the proteins, as well as the association of the compounds to the charcoal.

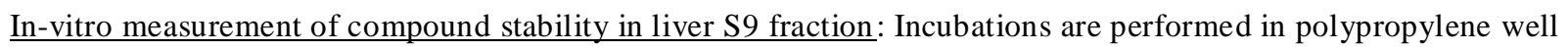
plates containing containing buffer/S9 mix (+/- NADPH). Compound is spiked in at a concentration of $1 \mu \mathrm{M}$ to start the incubation $\left(37^{\circ} \mathrm{C}, 100 \mathrm{rpm}\right)$. The incubations were stopped at $0,5,15,30,60$ and 120 min by the addition $400 \mu \mathrm{L}$ of acetonitrile of $100 \mathrm{uL}$ incubation mixture. The stopped incubations were centrifuged at $3500 \mathrm{~g}$ for 25 min at $4{ }^{\circ} \mathrm{C}$. The supernatant was analyzed by using a high performance liquid chromatography-tandem mass spectrometry (LC-MS/MS) system consisting of a Thermo TSQ Quantum Discovery Max 1.5 mass spectrometer, an electrospray ion source, a CTC PAL autosampler 2.2.0 and Janeiro CNS dual pumps 1.1 powered by XCalibur 2.0.7 and Quick Quan 2.1 software. Samples were separated on a 50 x 2 mm Synergi Polar-RP column (4 microns) using a generic fast mobile phase gradient (outlined in Table 2-4). Mobile phase A consisted of $0.1 \%$ formic acid in HPLC grade water. Mobile phase B consisted of $0.1 \%$ formic acid in HPLC grade acetonitrile. The first 0.7 min of eluent were diverted to waste to avoid source fouling. Peak area ratios of analyte:internal standard were derived to calculate $\%$ stability and half-life.

Hepatocyte stability: Incubations are performed in 96 quartz glass well plates and started by the addition of $50 \mu \mathrm{L}$ cryopreserved hepatocytes ( 1 Mio cells $/ \mathrm{mL}$ final concentration) to $50 \mu \mathrm{L}$ compounds ( $1 \mu \mathrm{M}$ final concentration) dissolved in Leibovitz's L-15 Medium. The incubations were stopped at 1, 10, 20, 40, 60 and 80 min by the addition of $150 \mu \mathrm{L}$ acetonitrile containing $0.1 \%$ formic acid and $0.4 \mu \mathrm{M}$ Glyburide (internal standard). The stopped incubations were centrifuged at $4000 \mathrm{~g}$ for $35 \mathrm{~min}$ and the supernatant was analyzed by LC-MS(MS) using a highresolution mass spectrometer in data-dependent mode. Data evaluation for determination of CLint (parent depletion) and metabolic soft spot identification (SSID) was done using Mass-MetaSite and in-house Exceltemplates. For the estimation of the in vitro metabolic clearance rate, the percentage of test article remaining relative to time zero minute incubation was used to determine the in vitro elimination-rate constant (kmic) and half-live 
$(\mathrm{t} / 2)$. Intrinsic clearance (CLint) was calculated by dividing kmic by the concentration of microsomal protein $(0.5$ $\mathrm{mg} / \mathrm{mL})$.

Stability in liver microsomes: Microsomal incubations were performed in 384-well PCR plates at $37{ }^{\circ} \mathrm{C}$ on an automated Hamilton RackRunner/STARlet platform (Hamilton, Bonaduz, Switzerland). Test articles at a concentration of $10 \mathrm{mM}$ in pure DMSO were dispensed by an acoustic dispenser ECHO 520 (25 nL) by wet dispenseto $25 \mu \mathrm{L} 100 \mathrm{mM}$ phosphate buffer (pH 7.4) containing $2 \mathrm{mM}$ NADPH. This solution (12.5 $\mu \mathrm{L}$, equilibrated for $10 \mathrm{~min}$ at $37{ }^{\circ} \mathrm{C}$ ) was added to $12.5 \mu \mathrm{L}$ liver microsomal protein $(1 \mathrm{mg} / \mathrm{mL})$ suspended in $100 \mathrm{mM}$ phosphate buffer (pH7.4). At specific time points $(0.5,5,15$, and $30 \mathrm{~min})$, the reactions were terminated by the addition of $10 \mu \mathrm{L}$ acetonitrile/formic acid (93:7) containing the analytical internal standards ( $1 \mu \mathrm{M}$ alprenolol and $1 \mu \mathrm{M}$ glyburide) and transferred completely to a new 384-well plate containing $15 \mu \mathrm{L}$ acetonitrile/formic acid (93:7). The stopped incubations were centrifuged at $5000 \mathrm{~g}$ for $15 \mathrm{~min}$ at $4{ }^{\circ} \mathrm{C}$ and $30 \mu \mathrm{L}$ of the supernatants were transferred to a new 384 well plate for LC-MS analysis. Analysis of samples was performed on a high performance liquid chromatographytandem mass spectrometry system (LC-MS) consisting of a Shimadzu Nexera LC-system and a Sciex QTrap 5500 mass spectrometer controlled by Analyst 1.7 from AB Sciex. Compound specific parameters were obtained by automatic tuning using the DiscoveryQuant 3.0.7. These parameters were stored in a database to be used for selective quantitation of each test article. Samples of microsomal incubations were separated on a Phenomenex Kinetx Polar C18, 2.1*30 mm, $2.6 \mu \mathrm{m}$ column (Brechbühler, Schlieren, Switzerland). The components were eluted with a gradient of $0.1 \%$ formic acid (mobile phase A) versus $0.1 \%$ formic acid in acetonitrile (mobile phase B) at a flow of 800 $\mu \mathrm{L} / \mathrm{min}$ at $50{ }^{\circ} \mathrm{C}$ using the following gradient: $0 \min 2 \% \mathrm{~B} ; 0.2 \min 2 \% \mathrm{~B} ; 1 \mathrm{~min} 60 \% \mathrm{~B} ; 1.3 \mathrm{~min} 100 \% \mathrm{~B} ; 1.7 \mathrm{~min}$ $100 \% \mathrm{~B} ; 1.71 \min 2 \% \mathrm{~B}$ and $1.95 \min 2 \% \mathrm{~B}$. The injection volume was $2 \mu \mathrm{L}$. For the estimation of the in vitro metabolic clearance rate, the percentage of test article remaining relative to time zero minute incubation was used to determine the in vitro elimination-rate constant (kmic) and half-live ( $\mathrm{t} 1 / 2)$. Intrinsic clearance (CLint) was calculated by dividing kmic by the concentration of microsomal protein $(0.5 \mathrm{mg} / \mathrm{mL})$.

Stability in blood: For determination of stability in blood stability, the same method as for the plasma stability assay was used. Due to the viscosity of blood manual incubation was done.

Stability in human feces incubations: The preparation of the feces suspension and the stability assays were performed in anaerobic buffer and under nitrogen atmosphere. The anaerobic buffer was composed of $100 \mathrm{mM}$ potassium phosphate buffer $\mathrm{pH} 7$, dithiothreitol $0.5 \mathrm{~g} / \mathrm{L}$ and resazurine $1 \mathrm{mg} / \mathrm{L}$ and the oxygen was removed by autoclaving at $120{ }^{\circ} \mathrm{C}$ for $20 \mathrm{~min}$. Fresh feces (single donor) were mixed with 4 volume equivalents of anaerobic buffer. $10-15 \mathrm{~mL}$ of the feces suspension were transferred into nitrogen-flushed tubes and mixed for 1.5 min using the Dispomix blender. 
After the mixing the tubes were flushed with nitrogen again, and the suspension was diluted with anaerobic, $15 \%$ glycerol buffer to achieve a final concentration of $10 \%$ feces (w/v) and $7.5 \%$ of glycerol (w/v). Portions of $0.5 \mathrm{~mL}$ of the homogenate were dispensed into $2 \mathrm{~mL}$ Eppendorf tubes flushed with nitrogen gas before and after filling and were stored at $-80^{\circ} \mathrm{C}$ until use. Compound incubations: $0.5 \mathrm{~mL}$ feces reaction stocks were thawed at room temperature and mixed with $12 \mathrm{uL}$ of the compound stock solution (4 $\mathrm{mg} 24$ in $1 \mathrm{~mL} \mathrm{MeOH}$ ). One reaction was incubated at $30{ }^{\circ} \mathrm{C}$, $400 \mathrm{rpm}$ under nitrogen atmosphere for 24 hours and a second reaction for 48 hours. The reactions were stopped by adding $0.5 \mathrm{~mL}$ of acetonitrile. After mixing at room temperature for $20 \mathrm{~min}$ and centrifugation at $25000 \mathrm{xg}$ for $2 \mathrm{~min}$ the supernatants were stored at $-20{ }^{\circ} \mathrm{C}$ until subjected to analysis by liquid chromatography with mass spectroscopy. Salicylazosulfapyridine was used as a positive control and was incubated under the same conditions. Negative controls without the feces in buffer were also carried out. Supernatants were transferred into LC tubes for UPLC analysis.

$\begin{array}{ll}\begin{array}{l}\text { UPLC } \\ \text { column }\end{array} & \text { WATERS UPLC Acquity with PDA detector } \\ \text { mobile phase } & \text { Waters Acquity HSS T3; } 1.7 \mu \mathrm{m} ; 1.0 \times 150 \mathrm{~mm}\left(40{ }^{\circ} \mathrm{C}\right) \\ \text { flow: } & \mathrm{A}: \mathrm{H}_{2} \mathrm{O}+0.02 \% \mathrm{TFA} \mathrm{B}: \mathrm{CH}_{3} \mathrm{CN}+0.02 \% \mathrm{TFA} \\ \text { gradient (\%B) } & 100 \mu \mathrm{l} / \mathrm{min} \\ \text { injection } & 1 \mathrm{~min} 5 \% \mathrm{~B}, 16 \mathrm{~min} 75 \% \mathrm{~B} 18 \mathrm{~min} 95 \% \mathrm{~B} 20 \mathrm{~min} 95 \% \mathrm{~B} \\ \text { detection } & 1.5 \mu \mathrm{L} \text { of the samples as received } \\ \text { MS } & 210 \mathrm{~nm}-400 \mathrm{~nm} \\ \text { Ionization } & \text { LTQ Velos, Thermo-Scientific, San Jose } \\ \text { Scan range } & +\mathrm{ESI} \\ & m / z 130-600\end{array}$

Caco-2 cell incubations: Caco-2 cells were obtained from the American Type Cell Culture (ATCC) repository (Manassas, VA). The Caco-2 culture medium contained the following: Dulbecco's Modified Eagle Medium, 10\% heat inactivated fetal bovine serum, $0.1 \mathrm{mM}$ nones-sential amino acid solution, $1 \mathrm{mM}$ sodium pyruvate solution (Invitrogen, Carlsbad, CA; Hyclone, Logan,UT). Hank's balanced salt solution (HBSS) and N-2hydroxyethylpiperazine-N0-2-ethanesulfonic acid(HEPES) were obtained from Mediatech, Inc. (Manassas, VA). A 96-Multiwell Insert System was purchased from BD Biosciences (Billerica, MA) and used for the cell culture and permeability assay. All solvents were analytical grade and standard test compounds were obtained from Sigma-Aldrich (St. Louis, MO) or the Novartis Compound Management Unit and used without further purification. The Caco-2 cells were grown and maintained at $37{ }^{\circ} \mathrm{C}, 5 \% \mathrm{CO}_{2}$, and $>95 \%$ relative humidity until approximately $80-90 \%$ confluent. When at the desired confluency, Caco- 2 cells were seeded onto insert wells at a density of $1.48 \times 10^{5}$ cells per $\mathrm{mL}$. Culture medium was automatically replaced by fresh medium every 2-3 days using an integrated Tecan Genesis 150 and Heraeus Heral cell 150 incubator platform. Cells were allowed to 
grow and differentiate for 19-23 days before assays were performed. Freshly prepared transport buffer at pH 7.4 (HBSS with $10 \mathrm{mM}$ HEPES) was warmed to $37^{\circ} \mathrm{C}$. The plates of the Insert System were rinsed three times with the transport buffer, followed by transepithelial electricalresistance $\left(\mathrm{TEER}, \mathrm{Vcm}^{2}\right)$ measurement with an EVOM ohmmeter and fixed electrode (World Precision Instruments, Sarasota, FL). Caco-2 insert plates with TEER values $>200 \mathrm{Vcm}^{2}$ were used for the assay, with typical values between 300 and $400 \mathrm{Vcm}^{2}$. To measure both absorptive (apical or AP tobasolateral or BL) and secretory (BL to AP) transport, solutions of test compounds at $10 \mathrm{mM}$ in $0.5 \%(\mathrm{v} / \mathrm{v}) \mathrm{DMSO} /$ transport buffer were added to donor wells(here apical wells for absorptive and basolateral wells for secretory transport). Opposing acceptor wells received only transport buffer. Volume of the apical and basolateral wells was maintained at 75 and $250 \mu \mathrm{L}$, respectively. A Tecan Genesis 150 was specifically designed to prepare and then incubate/shake the Caco-2 assay plate at $37^{\circ} \mathrm{C}$ for $120 \mathrm{~min}$. The Genesis station accommodated up to four Insert Systems, for a total of 56 test compounds plus standards measured in dual transport directions intriplicate per run. Additionally, the Genesis work-station prepared the analytical plate by collecting donor at $\mathrm{t}=0$ and donor/acceptor at $\mathrm{t}=120 \mathrm{~min}$ samples from each well. After a protein precipitation step with acetonitrile (ACN), analytical plates were centrifuged and the supernatant was collected for LC/MS/MS injection. Following sample collection for the analytical plate, the Insert System was incubated a second time with $100 \mathrm{mM}$ Lucifer Yellow for 60 min, after which donor and acceptor fluorescence was read using a Magellan5 (Ex: 430 nm; Em: 535 nm). Wells with Lucifer Yellow A-B permeability $>1 \times 10^{-6} \mathrm{~cm} / \mathrm{s}$ were rejected during data analysis. Analysis of samples was performed on a high-performance liquid chromatography-tandem mass spectrometry (LC/MS/MS) system consisting of a Waters Quattro Premier Mass Spectrometer (Waters,Milford, MA), Agilent 1100 LC System (Agilent, PaloAlto, CA), and CTC-HTC Leap auto-sampler with cooling stacks capacity (CTC Analytics, Carrboro, NC). The ionization source was electrospray (ESI). Samples were separated on an Atlantis dC 18 column (2.1 mm x 30 $\mathrm{mm}, 3.5 \mathrm{~mm}$, Waters) using a fast mobile phase $1.15 \mathrm{~min}$ gradient. Mobile phase A consisted of $10 \mathrm{mM}$ ammonium formate $(\mathrm{v} / \mathrm{v})$ in water. Mobile phase B consisted of ACN with $0.1 \%$ formic acid (v/v). MS/MS conditions for compounds were optimized using the Waters software QuanOptimize, while in-house software facilitated batch sample list generation and data review. The parameters $P_{\text {app }}$ (apparent permeability) and efflux ratio are calculated as follows:

$\mathbf{P}_{\text {app }}=(\mathrm{dQ} / \mathrm{dt}) \times\left(1 / \mathrm{C}_{0}\right) \times(1 / \mathrm{A})$

Efflux ratio $=\mathrm{P}_{\text {app }}[\mathrm{B} \rightarrow \mathrm{A}] / \mathrm{P}_{\text {app }}[\mathrm{A} \rightarrow \mathrm{B}]$

where $\mathrm{dQ} / \mathrm{dt}$ is the permeability rate, $\mathrm{C}_{0}$ is the initial concentration in the donor compartment, and $\mathrm{A}$ is the surface area of the cell monolayer $\left(0.33 \mathrm{~cm}^{2}\right)$. The Papp value is a rate measured in $\mathrm{cm} / \mathrm{s}$. 
$\underline{\text { In vivo studies }}$

Mouse PK: The animal experiments were performed in the metabolism and pharmacokinetics section of Novartis Pharma AG and done according to the regulations effective in the Canton Basel-City, Switzerland, specifically according to experimental license No. BS1587. Male mice (C57BL/6), originating from Charles River Iffa Crédo (France) were dosed intravenously at a dose $1.0 \mathrm{mg} \cdot \mathrm{kg}^{-1}$ solubilized in NMP:Plasma (10:90) using an administration volume of $5 \mathrm{~mL} / \mathrm{kg}$ or orally at a dose $3.0 \mathrm{mg} / \mathrm{kg}$ suspended in MC:Tween 80:water (0.5:0.5:99.0) using an administration volume of $10 \mathrm{~mL} / \mathrm{kg}$. Blood $(10 \mu \mathrm{L} /$ time point, without anticoagulant $)$ was collected by puncture of the lateral saphenous vein at different time points (i.v.: 0.083, 0.5, 1, 2, 4, 8, 24 h; p.o.: 0.25, 0.5, 1, 2, 4, 8, 24 h). from the same animal $(\mathrm{n}=3 ; 3 \mathrm{mice} /$ route/timepoint). The awake mice were restrained in a plastic tube for blood sampling. At the last time point, the animals were sacrificed. For bioanalytical investigation of blood samples protein precipitation was performed by mixing $10 \mu \mathrm{L}$ blood with $100 \mu \mathrm{L}$ acetonitrile and centrifuged at $4{ }^{\circ} \mathrm{C}$. $\sim 100 \mu \mathrm{L}$ of supernatant were transferred into a microtiter plate. An aliquot of each sample was injected into the LC-MS/MS system for analysis. Data analysis was done with Excel using a non-compartmental approach, according to internal in vivo study guidelines. The concentration at time zero was set to concentration at first measured time point for the calculation of the intravenous AUC. Based on the serial bleeding study design, the PK calculation was performed on individual concentration profiles. All calculations were based on the compounds free form.

Rat PK: The animal experiments were performed in the metabolism and pharmacokinetics section of Novartis Pharma $\mathrm{AG}$ and done according to the regulations effective in the Canton Basel-City, Switzerland, specifically according to experimental license No. BS1638. Six to four days before first drug administration, the rats (body weight approx. 290 g) were anesthetized and catheters were surgically implanted into the femoral artery (for blood collection) and femoral vein (for iv injection). The catheters were exteriorized at the neck where they were fixed via the tether and a flexible spring to a Harvard swivel system, which allowed blood sampling and iv injections without disturbing the freelymoving animal. For analgesic treatment, animals received Temgesic ${ }^{\circledR}(10 \mu \mathrm{g} / \mathrm{kg}$ s.c.) before surgery and subsequently twice at appropriate times after surgery. Animals were kept individually in Macrolon cages, with free access to food and water throughout the experiment. Male rats (Sprague Dawley (Crl: CD (SD))), originating from Charles River Wiga (Germany) were dosed intravenously at a dose $1.0 \mathrm{mg} / \mathrm{kg}$ solubilized in NMP:PEG200 (30:70) using with an administration volume of $0.5 \mathrm{~mL} / \mathrm{kg}$ or orally at a dose $3.0 \mathrm{mg} / \mathrm{kg}$ solubilized in Solutol HS15 in citrate buffer 100

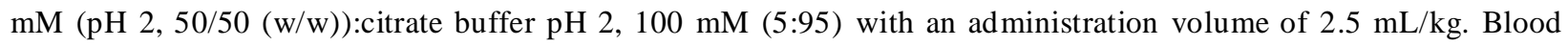
(EDTA, $\sim 50 \mu \mathrm{L}$ ) was collected via the catheter implanted into the femoral artery at different time points (i.v.: 0.083 , $0.25,0.5,1,2,3,4,6,8,24,48$ h; p.o.: 0.25, 0.5, 1, 2, 3, 4, 6, 8, 24 h). For bioanalytical investigation of blood samples protein precipitation was performed by mixing $30 \mu \mathrm{L}$ blood with $200 \mu \mathrm{L}$ acetonitrile and centrifuged at $4{ }^{\circ} \mathrm{C}$. $\sim 200$ $\mu \mathrm{L}$ of supernatant were transferred into a microtiter plate and mixed with $50 \mu \mathrm{L}$ water. An aliquot of each sample was 
injected into the LC-MS/MS system for analysis. Data analysis was done with Excel using a non-compartmental approach, according to internal in vivo study guidelines. Based on the serial bleeding study design, the PK calculation was performed on individual concentration profiles. All calculations were based on the compounds' free form.

Dog PK: Animal experiments are performed in the MAP Basel group. Procedures are in accordance with Swiss Animal Welfare regulations, effective in the Canton Basel-City, Switzerland, specifically according to experimental license No. BS2528. Adult male beagle dogs are used for the study. Dogs are fasted overnight before dosing (i.e. no special preparation necessary), and fed $2 \mathrm{~h}$ post-dose. Dogs are fed standard dog chow daily in one or two portions (approx. $300 \mathrm{~g}$ ); tap water is available ad libitum. For the PK experiment, the animals are kept singly in experimental cages up to the $24 \mathrm{~h}$ sampling time (no access to the dog runs during this time), and in pens thereafter. Light program during experimental conditions are similar to the housing conditions: daylight exposure (natural light). Experimental Conditions A test compound is orally (usually $0.3 \mathrm{mg} / \mathrm{kg}$, as suspension or solution, with $2 \mathrm{~mL} / \mathrm{kg}$ ) or intravenously (usually $0.1 \mathrm{mg} / \mathrm{kg}$, as a solution with $0.2 \mathrm{~mL} / \mathrm{kg}$ ) administered. Blood $(150 \mu \mathrm{L})$ is collected from the front leg vein into $1.2 \mathrm{~mL}$ polypropylene syringes containing EDTA as anticoagulant (at least $1.6 \mathrm{mg}$ sodium EDTA per mL blood) at pre-dose, $0.25,0.5,1,2,4,7,24 \mathrm{~h}$. All samples are collected on ice, and then frozen at $-20^{\circ} \mathrm{C}$ until analysis.

Bile-duct cannulated rat PK: Animal experiments are performed in the MAP Basel group. Procedures are in accordance with Swiss Animal Welfare regulations, effective in the Canton Basel-City, Switzerland, specifically according to experimental license No. BS2241. One Sprague Dawley male rat is generally used for the study. Before starting the experiment, the rat is acclimatized and kept in group under standard conditions (optimal health conditions [OHC], $22{ }^{\circ} \mathrm{C}$ in a special, acclimatized animal room with $12 \mathrm{~h}$ dark-light cycles, light from 06:00 to 18:00) with free access to tap water and pelleted rodent chow. After the surgery (i.e. after cannulation of the bile duct and of the blood vessels) and for the experiment, the animal is individually placed in a metabolic cage. In order to allow good ion ic balance during the experimental period (i.e. between surgery and sacrifice), drink water is replaced by Ringer solution (glucose $5 \%, \mathrm{NaCl} 0.9 \%$ and $\mathrm{KCl} 0.5 \%$ ). The day before drug administration, the rat is anaesthetized and then, under aseptic conditions, three catheters are successively implanted and fixed into (i) its femoral artery for blood collection, (ii) its femoral vein for drug administration and (iii) in its bile duct for continuous bile collection. After surgery, the animal is placed in a metabolic cage and connected to the freely-moving Harvard swivel system. Due to the continuous bile flow $(\sim 1 \mathrm{~mL} / \mathrm{h})$, the recovery period after the surgery is only about $24 \mathrm{~h}$ and the duration of the study (i.e. after drug injection) is $7 \mathrm{~h}$ post-dose. A test compound (usually $3 \mathrm{mg} / \mathrm{kg}, 0.5 \mathrm{~mL} / \mathrm{kg}$ in an NMP/TEG200 30:70, v/v formulation as a solution) is administered intravenously at via the catheter implanted into the femoral vein. Bile and urine are collected quantitatively (i.e. excreted volumes are recorded) at pre-defined time intervals (0-2 h, 2-4 h, 4-7 h) without disturbing the animal. Blood (50 $\mu \mathrm{L}$, EDTA as anticoagulant) is also withdrawn via the catheter implanted into the femoral artery at 1,4 and $7 \mathrm{~h}$ post-dose. After sacrificing the animal, liver and kidney are taken for analysis. 
All samples are collected on ice, and then frozen at $-80^{\circ} \mathrm{C}$ until analysis.

Preparation of standards: Standards (test compounds or authentic standards of metabolites) are dissolved in DMSO (2 $\mathrm{mM}$ ), then diluted with water/acetonitrile (9:1) or a mixture of the HPLC running buffers as required for tuning and comparison with samples.

Preparation of in vitro samples for metabolite characterization: Prior to analysis, each sample is centrifuged (10000 g, $5 \mathrm{~min})$ and $100 \mu \mathrm{L}$ supernatant is diluted with $400 \mu \mathrm{L}$ water and filtered if necessary to remove precipitate $(0.45 \mu \mathrm{m})$.

Preparation of in vivo samples for metabolite characterization: Bile and urine samples are diluted with water/acetonitrile (9:1; usually 10-200x dilution) and filtered if necessary to remove precipitate $(0.45 \mu \mathrm{m})$. Blood samples $(100 \mu \mathrm{L})$ are treated with $100 \mu \mathrm{L}$ acetonitrile $\left(0^{\circ} \mathrm{C}\right)$, mixed, and kept at $0{ }^{\circ} \mathrm{C}$ for $20 \mathrm{~min}$. This procedure is repeated twice, then the mixtures are centrifuged $(10000 \mathrm{~g}, 5 \mathrm{~min})$. Subsequently, the supernatant $(400 \mu \mathrm{L})$ is removed and concentrated using a Cyclone high speed evaporator (Prolab, Reinach, Switzerland). The residue is reconstituted with $250 \mu \mathrm{L}$ water/acetonitrile $(9: 1)$, and filtered if necessary to remove precipitate $(0.45 \mu \mathrm{m})$. Homogenized tissue samples $(300 \mu \mathrm{L})$ are treated with $300 \mu \mathrm{L}$ acetonitrile $\left(0^{\circ} \mathrm{C}\right)$, mixed, and kept at $0{ }^{\circ} \mathrm{C}$ for $20 \mathrm{~min}$. This procedure is repeated twice, then the mixtures are centrifuged $(10000 \mathrm{~g}, 5 \mathrm{~min})$. Subsequently, the supernatant $(1000 \mu \mathrm{L})$ is removed and concentrated using a Cyclone high speed evaporator (Prolab, Reinach, Switzerland). The residue is reconstituted with $250 \mu \mathrm{L}$ water/acetonitrile $(9: 1)$, and filtered if necessary to remove precipitate $(0.45 \mu \mathrm{m})$.

Preparation of samples for quantitative analyses: Sample preparation for quantitative analyses is optimized for each sample. In general, homogenized tissue, bile and urine samples are spiked with an internal standard and diluted 10 times with blank rat blood. Subsequently, acetonitrile is added to all diluted samples as well as blood samples spiked with internal standard. Finally the samples are centrifuged and an aliquot is injected to the LC-MS system.

HPLC-MS $^{(\mathrm{n})}$ metabolite identification analyses: Samples from in vivo experiments or in vitro incubations, as well as standard solutions (test compounds or authentic metabolite standards) are analyzed by LC-MS in order to detect and characterize metabolites. Liquid chromatographic separation is performed using a binary syringe pump, a $150 \mathrm{~mm} \mathrm{x}$ $0.3 \mathrm{~mm}$ capillary HPLC column containing C18 material, and a column oven (usually heated to $40{ }^{\circ} \mathrm{C}$ ). Gradient mobile phase programming is used with a flow rate of $4.5 \mu \mathrm{L} / \mathrm{min}$. Running buffers are optimized for each study. H/D exchange experiments are performed by replacement of water with deuterated water and methanol with $\mathrm{d}_{1}$-methanol. Samples are injected via an external loop. The column effluent is introduced directly into the ion source of a linear ion trap-Orbitrap hybrid mass spectrometer (Thermo Fischer Scientific, Waltham, MA, USA), using positive ion electrospray ionization. The mass spectrometers are used in the full scan mode in high resolution mode. Where 
necessary, data-dependent MS2 and MS3 product ion scans are collected simultaneously based on a list of potential metabolites, and/or defined MS2 and MS3 product ion scans are collected.

Quantitative analyses: Samples from in vivo experiments, as well as standard solutions (test compounds or authentic metabolite standards) are analyzed by LC-MS in order to quantify the standard compounds. Chromatography and mass spectrometry are optimized for each sample. In general, aliquots of sample solutions as well as calibration and quality control samples are spiked with an internal standard and are separated on a HPLC column with a mobile phase gradient. The column effluent of the HPLC system is directly introduced into the ion source of a triple quadrupole or quadrupole-orbitrap hybrid mass spectrometer operating with electrospray ionization.

Data evaluation and interpretation: LC-MS data from metabolism experiments are analyzed in order to determine the structure of metabolites, and/or the quantity of known compounds for which an authentic standard is available. Structure determination studies are analyzed by searching LC-MS data for the $\mathrm{m} / \mathrm{z}$ values of potential metabolites (either manually or using an appropriate computer program), then proposing structures based on the MS ${ }^{n}$ fragmentation of the precursor ion for each compound. Structures are in some cases further clarified by analysis of the number of exchangeable hydrogen atoms determined by LC-MS measurements of the same samples in deuterated solvents (usually $\mathrm{D}_{2} \mathrm{O}$ and $\mathrm{CH}_{3} \mathrm{OD}$ ). Results are presented as proposed metabolite structures and/or proposed metabolism pathways. Relative LC-MS peak areas (for the $m / z$ signals of the respective components) may also be reported. LC-MS peak area data from metabolite identification studies without calibration standards are not quantitative, as mass spectrometric response strongly depends on the ionization efficiency of each individual compound, the extent of any dissociation or adduct formation during the ionization process, the solvent comp osition of the HPLC gradient at the time of elution, and ion suppression from the biological matrix and co-eluting compounds. For these reasons the actual relative amounts of parent and metabolites may differ substantially from relative peak areas, in some cases by orders of magnitude. It is also likely that some metabolites are not detectable under the ionization conditions used in a particular experiment, or are not identified due to having an unusual or ambiguous structure. Relative peak areas are reported only for order of magnitude estimations of metabolite abundance, and for comparison between samples analyzed under the same conditions, such as species comparisons using in vitro incubation samples. If an authentic metabolite standard is available, a semi-quantitative response factor is estimated by calculating the ratio of the peak areas of the metabolite and the test compound $\mathrm{m} / \mathrm{z}$ signals in a standard solution. Quantification of known compounds in samples obtained from in vivo studies is carried out by measuring peak integrals for a compound and an internal standard, with an 8-level calibration curve (in triplicate) using blank rat blood samples spiked with external and internal standards. Peak integrals are calculated either using the compound $m / z$ signal or the $m / z$ signal for a characteristic product ion in a MS-MS experiment. Mass balance calculations for in vivo studies are performed using these quantitative data, and the measured volume/weight of each tissue/sample. 
$\underline{P K / P D}$ and efficacy studies in the mouse and rat: Xenograft studies were performed at Novartis within the Basel facility and conducted under licenses approved by the Cantonal Veterinary Office Basel-Stadt (BS-2498 and BS2499). Details of how the experiments were conducted are described in reference 51 from the main text.

Body weight change in the mouse Hep3B xenograft study with 43 (Figure 15 main text)

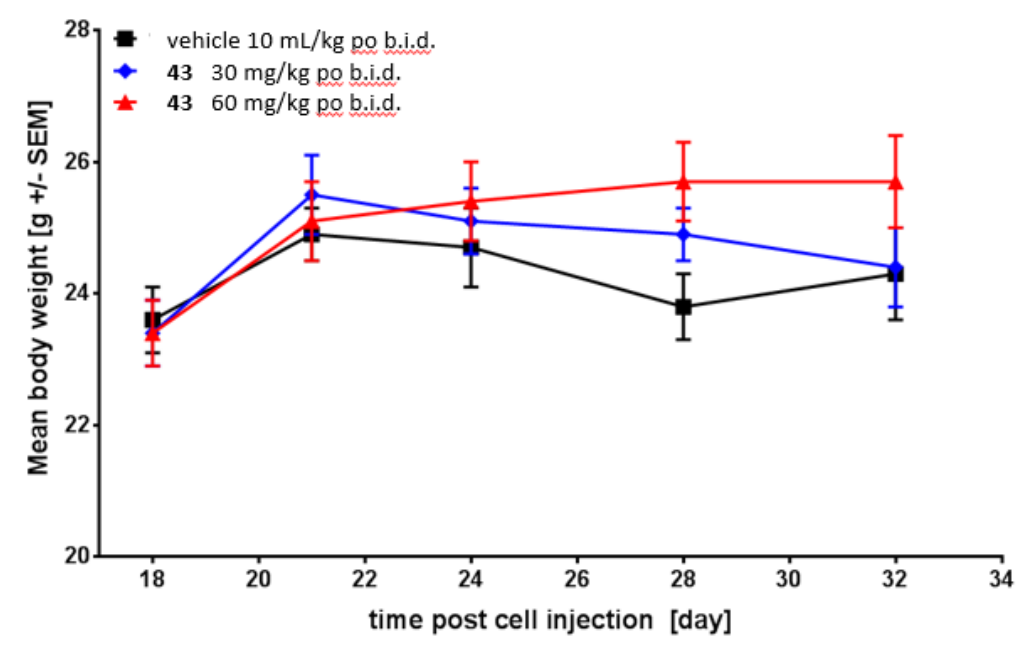

Body weight change in the mouse HUH7 xenograft study with 68 (Figure 18 main text)

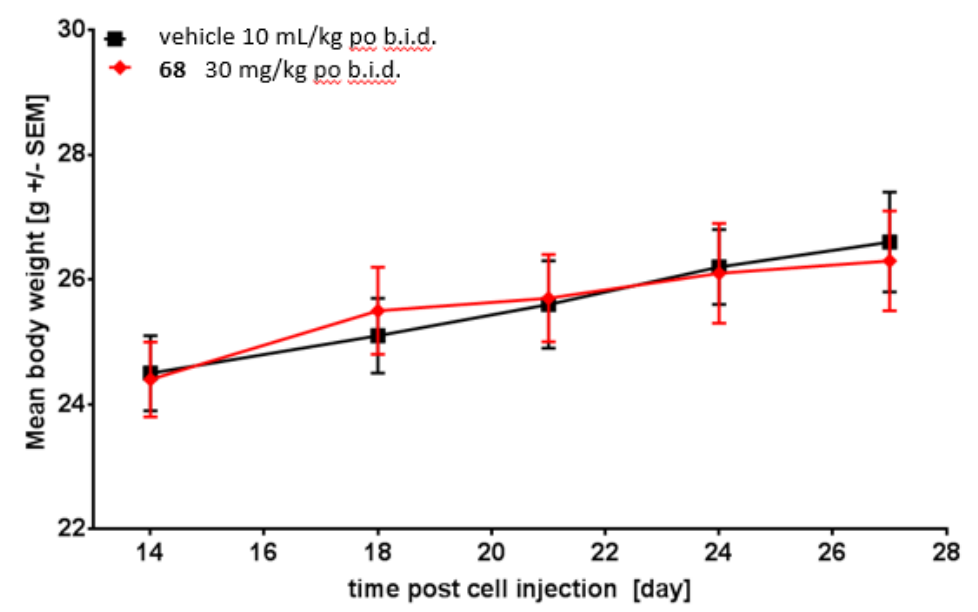


Body weight change in the mouse Hep3B xenograft study with 84 (Figure 24 main text)

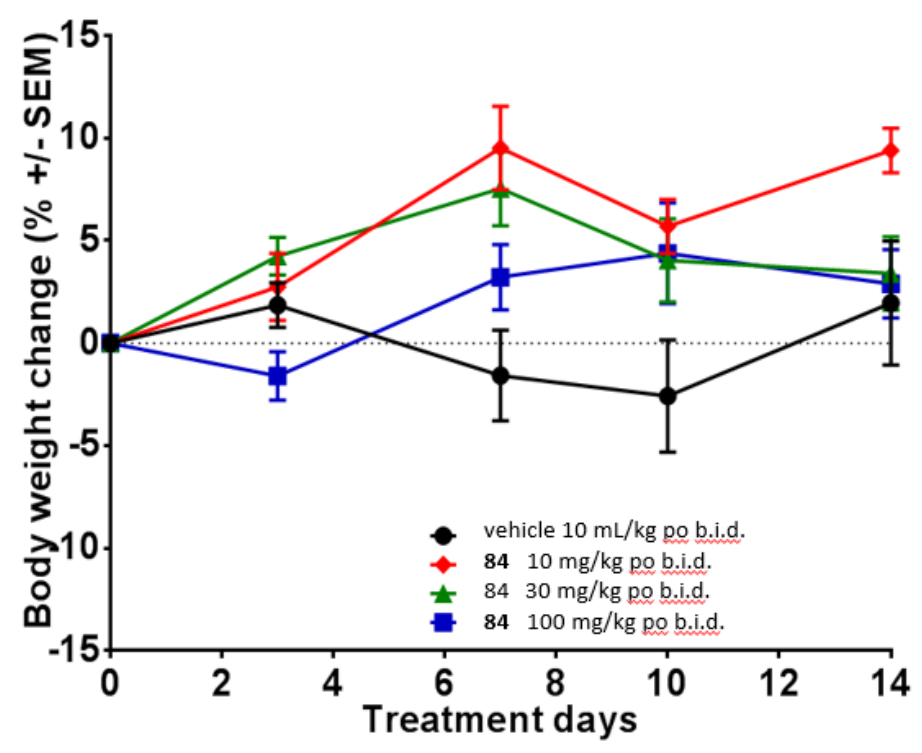

Body weight change in the rat HUH7 xenograft study with 84 (Figure 25 main text)

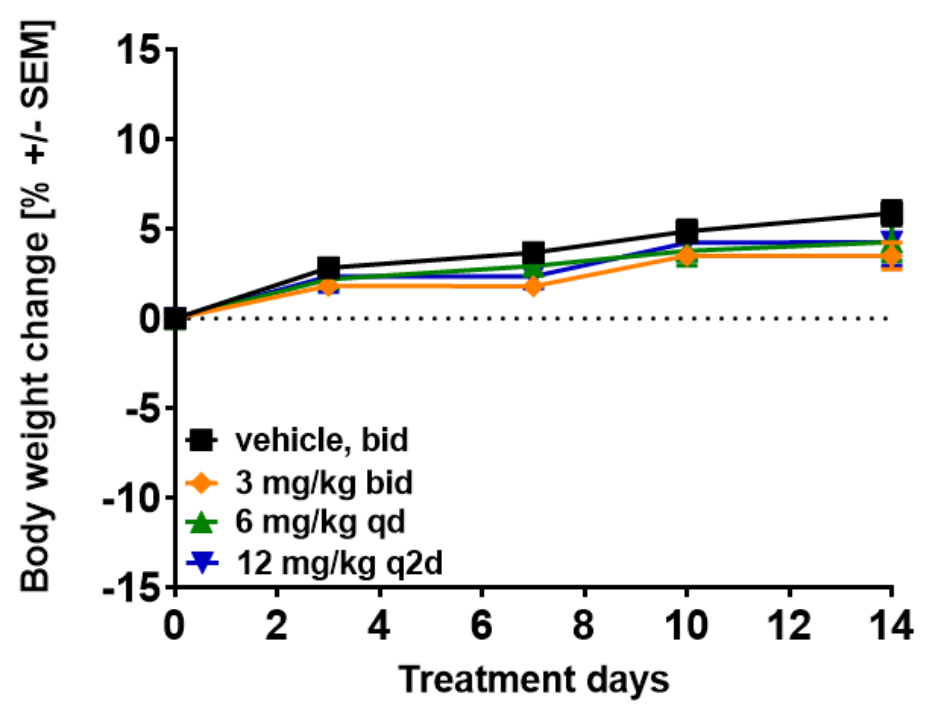


Rat toxicology study: This study was conducted in accordance with the Novartis Animal Care and Use Committeeapproved generic protocol no. TX 4039. The study sponsor was Novartis Pharmaceuticals Corporation, East Hanover, New Jersey 07936 and the study was conducted within the East Hanover facility. Four groups of male Wistar Hannover rats ( $\mathrm{n}=4$ /group) were given oral (gavage) doses of vehicle or compound $\mathbf{6 8}$ at 10,30 and $100 \mathrm{mg} / \mathrm{kg} / \mathrm{day} \mathrm{for} 10 \mathrm{days}$. Clinical observations, body weight and food consumption determinations were performed on all groups. Clinical laboratory evaluations (hematology, hemostasis/thrombosis, clinical chemistry) were conducted on all animals on days 1 and 10. Necropsies were conducted on day 10 at approximately 8 hours postdose. Gross pathology examinations and organ weight determinations were performed on all groups. Microscopic examinations were conducted on a select list of organs and tissues from all animals. Representative liver and ileum samples were collected from each animal at necropsy for determination of mRNA levels of CYP7A1 and selected bile acids and bilirubin transporters. These samples were snap frozen in liquid nitrogen and stored at approximately $-70{ }^{\circ} \mathrm{C}$ or below prior to analysis. Blood samples were serially collected from each rat on days 1-2 and day 10 at $0.5,1,2,4,8$ and 24 (for days 1-2 only) post dose. 


\section{Compound synthesis: Schemes 1-4}

Experimental Procedures: Solvents and reagents were purchased from suppliers and used without any further purification. Normal phase chromatography was conducted using a Teledyne ISCO, CombiFlash Rf system with silica gel pre-packed columns (RediSep Rf) and TLC plates pre-coated with silica gel 60 F 254 on aluminum (Merck KGaA) with detection by UV $(254 \mathrm{~nm})$. The $\mathrm{pH}$ of solutions were measured using pHix 0-14 paper (FisherBrand). LC-MS was conducted using: Waters Acquity UPLC with Waters SQ detector; eluting with gradients of aqueous acetonitrile containing modifiers. Retention times $\left(t_{R}\right)$ and selected peaks from positive and negative ionisation modes as $\%$ of the base peak are reported. Proton, fluorine and carbon NMR experiments were performed using Bruker Ultrashield 400, Varian Mercury $400 \mathrm{MHz}, 500 \mathrm{MHz}$ DRX Bruker CryoProbe and $600 \mathrm{MHz}$ Brucker Ultrashield instruments. Chemical shifts $(\delta)$ are quoted in ppm relative to residual proton peaks in solvent. The multiplicity of the signals are indicated as s-singlet, d-doublet, t-triplet, q-quartet, p-pentet, hept-heptet, m-multiplet, or br-broad. Coupling constants are quoted in $\mathrm{Hz}$ to one decimal place. For NMR, the solvents were chosen according to the position of solvent peaks in the spectra and based upon the solubility of the measured compound. ${ }^{1} \mathrm{H},{ }^{1} \mathrm{H}-\mathrm{COSY}$ and -ROESY experiments were conducted following reported procedures. ${ }^{\mathrm{S} 7, \mathrm{~S} 8}{ }^{13} \mathrm{C}$ - and ${ }^{15} \mathrm{~N}-\mathrm{HMBC}$ experiments were conducted following reported procedures. ${ }^{\text {S9 }}$ Infrared and Raman spectroscopy were carried out using Vector 22 FT-IR and MultiRam Raman spectrometers (Bruker Optics). UV-visible spectroscopy was carried out using a Cary 300 Scan spectrometer (Varian). Quantitative analyses were performed by Solvias AG. Within this text, room temperature (RT) is defined as $19-25^{\circ} \mathrm{C}$. The term in vacuo is used to describe solvent removal by Büchi rotary evaporation between 17 and $40{ }^{\circ} \mathrm{C}$, at $20-500$ mbar unless otherwise stated. Stated yields are from single experiments, or where multiple experiments have been carried out a range is reported.

\section{$\underline{\text { LC/MS methods }}$}

Method A: column Acquity HSS T3 $1.8 \mu \mathrm{m} 2.1$ x $50 \mathrm{~mm}$ at $60{ }^{\circ} \mathrm{C}$; gradient from 5 to $98 \%$ acetonitrile $+0.04 \%$ formic acid in water $+0.05 \%$ formic acid $+3.75 \mathrm{mM}$ ammonium acetate over $1.4 \mathrm{~min}$, flow $1.0 \mathrm{~mL} / \mathrm{min}$.

Method B: column Acquity HSS T3 $1.8 \mu \mathrm{m} 2.1$ x $50 \mathrm{~mm}$ at $50{ }^{\circ} \mathrm{C}$; gradient from 2 to $98 \%$ acetonitrile $+0.04 \%$ formic acid in water $+0.05 \%$ formic acid $+3.75 \mathrm{mM}$ ammonium acetate over $1.4 \mathrm{~min}$, flow $1.2 \mathrm{~mL} / \mathrm{min}$.

Method C: column Aquity UPLC BEH C18 $1.7 \mu \mathrm{M} 2.1 \times 100 \mathrm{~mm}$, at $80{ }^{\circ} \mathrm{C}$; gradient from 1 to $60 \%$ (8.4 min), 60 to $98 \%(1 \mathrm{~min}) \mathrm{iPrOH}+0.05 \%$ formic acid in water $+4.8 \% \mathrm{PrOH}+0.05 \%$ formic acid $+3.75 \mathrm{mM} \mathrm{NH}_{4} \mathrm{OAc}_{\mathrm{over}} 10$ min, flow $0.4 \mathrm{~mL} / \mathrm{min}$. 
Scheme 1 Synthetic routes to the hinge-binding 2-aminopyridine intermediates 96 and 97

4-fluoro-5-iodopyridin-2-amine

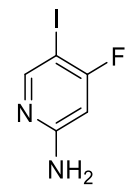

A suspension of 4-fluoropyridin-2-amine (336 g, $2.5 \mathrm{~mol})$ and NIS (745 g, $2.75 \mathrm{~mol}$ ) in MeCN (9 L) was treated with TFA (114 g, $1 \mathrm{~mol})$. The reaction mixture was then stirred at room temperature for $8 \mathrm{~h}$, then diluted with EtOAc (10 L) and washed with saturated aq. $\mathrm{Na}_{2} \mathrm{~S}_{2} \mathrm{O}_{3}(2 \times 5 \mathrm{~L})$, followed by brine $(4 \times 5 \mathrm{~L})$. The combined organic layers were dried over $\mathrm{Na}_{2} \mathrm{SO}_{4}$, filtered and concentrated to give the crude product. The crude product was purified by recrystallization from EtOAc/pentane (1:10) to afford the title compound as a white solid. LC-MS (method A) tR 0.66 $\min , m / z 239.0(100 \%, \mathrm{M}+\mathrm{H}), 280.0\left(70 \%, \mathrm{M}+\mathrm{CH}_{3} \mathrm{CN}+\mathrm{H}\right) .{ }^{1} \mathrm{H}$ NMR (400 MHz, DMSO-d6) $\delta 8.10(\mathrm{~d}, J=9.8 \mathrm{~Hz}$, $1 \mathrm{H}, \mathrm{Ar} \mathrm{H}), 6.41$ (s, br, 2H, NH 2$), 6.29$ (d, $J=10.9 \mathrm{~Hz}, 1 \mathrm{H}, \mathrm{Ar} \mathrm{H})$.

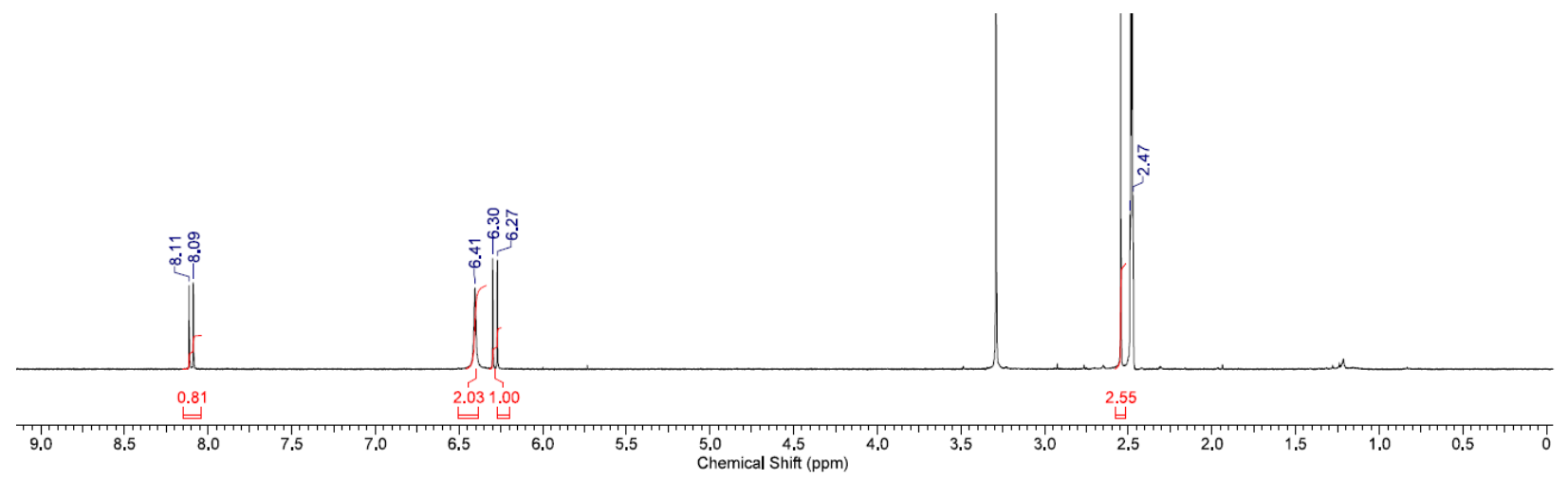


$\underline{6 \text {-amino-4-fluoronicotinonitrile } 95}$

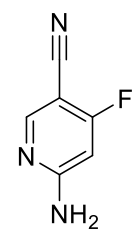

4-fluoro-5-iodopyridin-2-amine (240 g, $1 \mathrm{~mol})$, zinc cyanide (125 g, $1.05 \mathrm{~mol})$, zinc (13 g, $0.2 \mathrm{~mol}), \mathrm{Pd}_{2}(\mathrm{dba}) 3(25 \mathrm{~g}$, $25 \mathrm{mmol})$ and dppf $(55 \mathrm{~g}, 0.1 \mathrm{~mol})$ in DMA $(800 \mathrm{~mL})$ were degassed and charged into a round bottom flask under nitrogen. The mixture was stirred at $100{ }^{\circ} \mathrm{C}$ for $3 \mathrm{~h}$. The cooled reaction mixture was diluted with $5 \% \mathrm{NaHCO}_{3}(2 \mathrm{~L})$, and extracted with EtOAc $(4 \times 600 \mathrm{~mL})$. The combined organic layers were washed with $5 \% \mathrm{NaOH}(1 \mathrm{~L})$, dried over $\mathrm{Na}_{2} \mathrm{SO}_{4}$, and concentrated to $700 \mathrm{~mL}$. The resulting organic phase was eluted through silica gel column with EtOAc $(1.7 \mathrm{~L})$. The combined organic filtrate was washed with $2 \mathrm{M} \mathrm{HCl}(3 \mathrm{x} 800 \mathrm{~mL})$. The pH of the aqueous phase was adjusted to 10 with saturated $\mathrm{NaHCO}_{3}$ and then extracted with DCM (3 x $\left.500 \mathrm{~mL}\right)$. The combined DCM layers were dried over $\mathrm{Na}_{2} \mathrm{SO}_{4}$ and concentrated. The residue was further purified by column chromatography (eluted with pentane/EtOAc 10:1 to 3:2) followed by recrystallization from pentane/EtOAc 3:1 to give the title compound as white solid. LC-MS (method A) tR $0.49 \mathrm{~min}, \mathrm{~m} / z 138.0(35 \%, \mathrm{M}+\mathrm{H}), 179.1\left(100 \%, \mathrm{M}+\mathrm{CH}_{3} \mathrm{CN}+\mathrm{H}\right), 136.0(100 \%, \mathrm{M}-\mathrm{H}) .{ }^{1} \mathrm{H}$ NMR (400 MHz, DMSO-d6) $\delta 8.39$ (d, $J=10.6 \mathrm{~Hz}, 1 \mathrm{H}, \mathrm{Ar} \mathrm{H}), 7.38$ (s, br, 2H, NH 2$), 6.33(\mathrm{~d}, J=12.5 \mathrm{~Hz}, 1 \mathrm{H}, \mathrm{Ar} \mathrm{H})$.

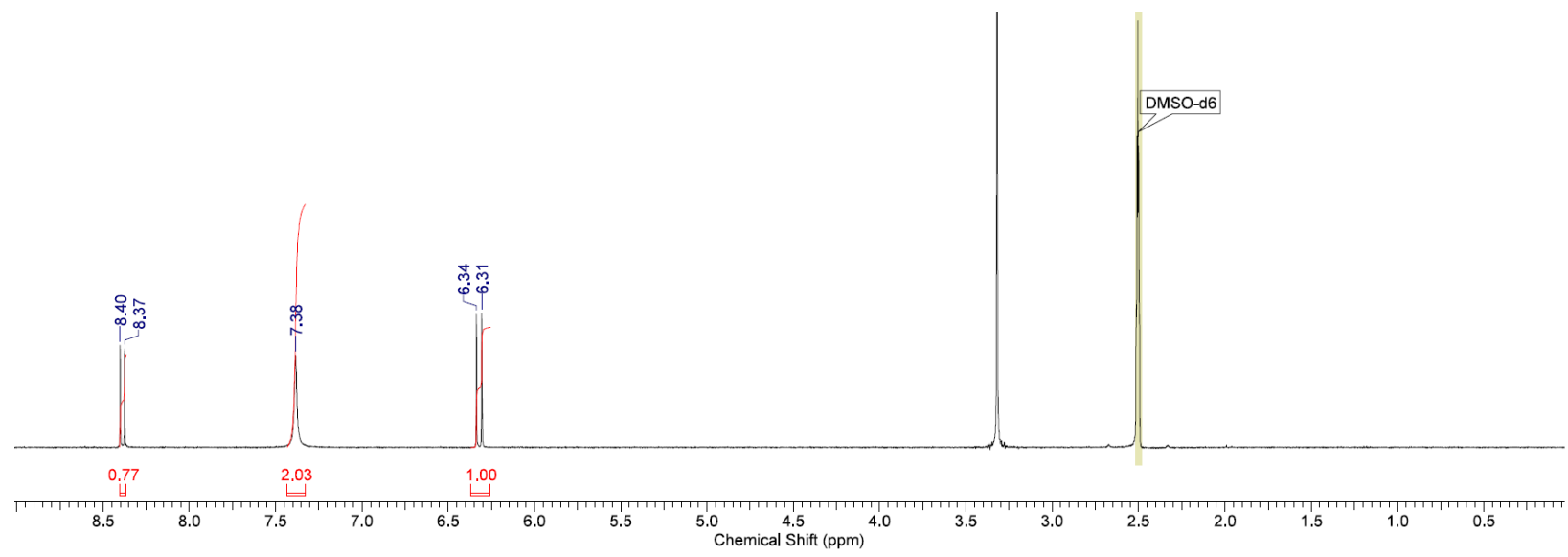


6-amino-4-((2-methoxyethyl)amino)nicotinonitrile 96

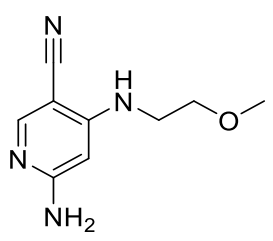

A solution of 6-amino-4-fluoronicotinonitrile $(\mathbf{9 5}, 1.10 \mathrm{~g}, 8.02 \mathrm{mmol})$ in DMA (20 mL) was treated with 2 methoxyethylamine $(2.07 \mathrm{~mL}, 24.1 \mathrm{mmol})$ and DIPEA $(4.20 \mathrm{~mL}, 24.1 \mathrm{mmol})$, heated to $50{ }^{\circ} \mathrm{C}$ and stirred for $15 \mathrm{~h}$. The reaction mixture was cooled to room temperature and concentrated. The crude material was purified by normal phase chromatography (24 g silica gel cartridge, heptanes/EtOAc 100:0 to 0:100). The product containing fractions were concentrated and dried under vacuum to give the title compound as an off-white solid. LC-MS (method A) tR $0.34 \mathrm{~min}, \mathrm{~m} / z$ 193.1 (100\%, M+H), $191.1(10 \%, \mathrm{M}-\mathrm{H}), 237.1\left(100 \%, \mathrm{M}+\mathrm{HCO}_{2}{ }^{-}\right) .{ }^{1} \mathrm{H}$ NMR $(400 \mathrm{MHz}, \mathrm{DMSO}-d 6) \delta$ $7.95(\mathrm{~s}, 1 \mathrm{H}, \mathrm{Ar} \mathrm{H}), 6.40\left(\mathrm{~s}, 2 \mathrm{H}, \mathrm{NH}_{2}\right), 6.14(\mathrm{t}, J=5.5 \mathrm{~Hz}, 1 \mathrm{H}, \mathrm{NH}), 5.65(\mathrm{~s}, 1 \mathrm{H}, \mathrm{Ar} \mathrm{H}), 3.50(\mathrm{t}, J=5.9 \mathrm{~Hz}, 2 \mathrm{H}$, $\mathrm{CH}_{2} \mathrm{OMe}$ ), $3.30\left(\mathrm{~s}, 3 \mathrm{H}, \mathrm{OCH}_{3}\right), 3.24\left(\mathrm{dd}, \mathrm{J}=5.5\right.$ and $\left.5.9 \mathrm{~Hz}, 2 \mathrm{H}, \mathrm{HNCH}_{2}\right)$.

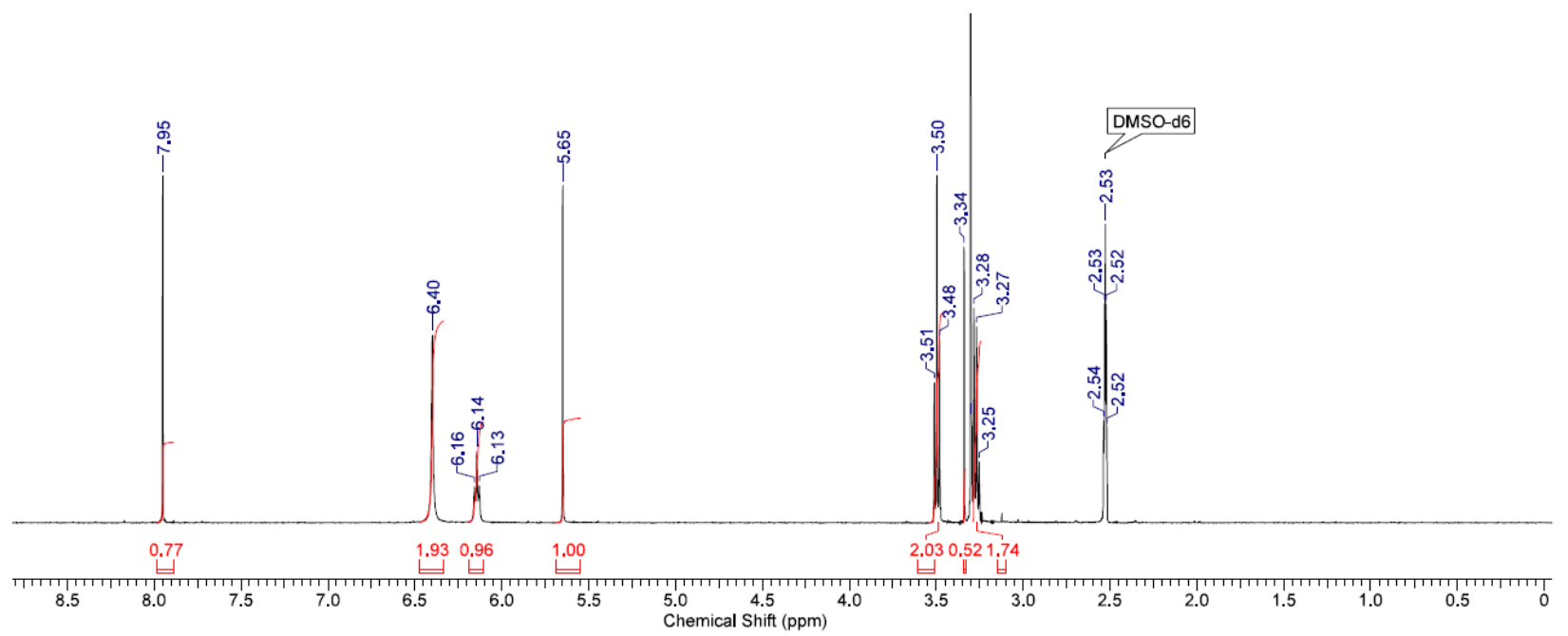




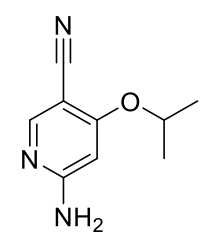

A solution of KHMDS (87 g, $438 \mathrm{mmol})$ was added portionwise to a solution of propan-2-ol (26.3 g, $438 \mathrm{mmol})$ in THF $(250 \mathrm{~mL})$ at room temperature. After $15 \mathrm{~min}$ a solution of 6-amino-4-fluoronicotinonitrile (95, $30 \mathrm{~g}, 219 \mathrm{mmol})$ in THF (200 mL) was added and the reaction mixture stirred for $18 \mathrm{~h}$ at room temperature. The reaction mixture was partitioned between saturated aqueous $\mathrm{NH}_{4} \mathrm{Cl}$ and EtOAc, extracted with EtOAc (2x), the combined EtOAc layers were dried over $\mathrm{Na}_{2} \mathrm{SO}_{4}$ and evaporated. The residue was triturated with $\mathrm{Et}_{2} \mathrm{O}$ and the product obtained by filtration as a yellow solid. LC-MS (method A) tR $0.62 \mathrm{~min}, \mathrm{~m} / z .136 .0$ (82\%, M-iPrO+H), $178.1(100 \%, \mathrm{M}+\mathrm{H}), 176.0(100 \%$, M-H). ${ }^{1} \mathrm{H}$ NMR (400 MHz, DMSO-d6) $\delta 8.10$ (s, 1H, Ar H), 6.79 (s, 2H, NH ), 6.04 (s, 1H, Ar H), 4.64 (septet, $J=$ $7.1 \mathrm{~Hz}, 1 \mathrm{H}, \mathrm{OCHMe}), 1.29\left(\mathrm{~d}, J=7.1 \mathrm{~Hz}, 6 \mathrm{H}, \mathrm{CH}\left(\mathrm{CH}_{3}\right)_{2}\right)$.

$\begin{array}{lllllllll}13.5 & 13.0 & 12.5 & 12.0 & 11.5 & 11.0 & 10.5 & 10.0 & \mathrm{ppm}\end{array}$

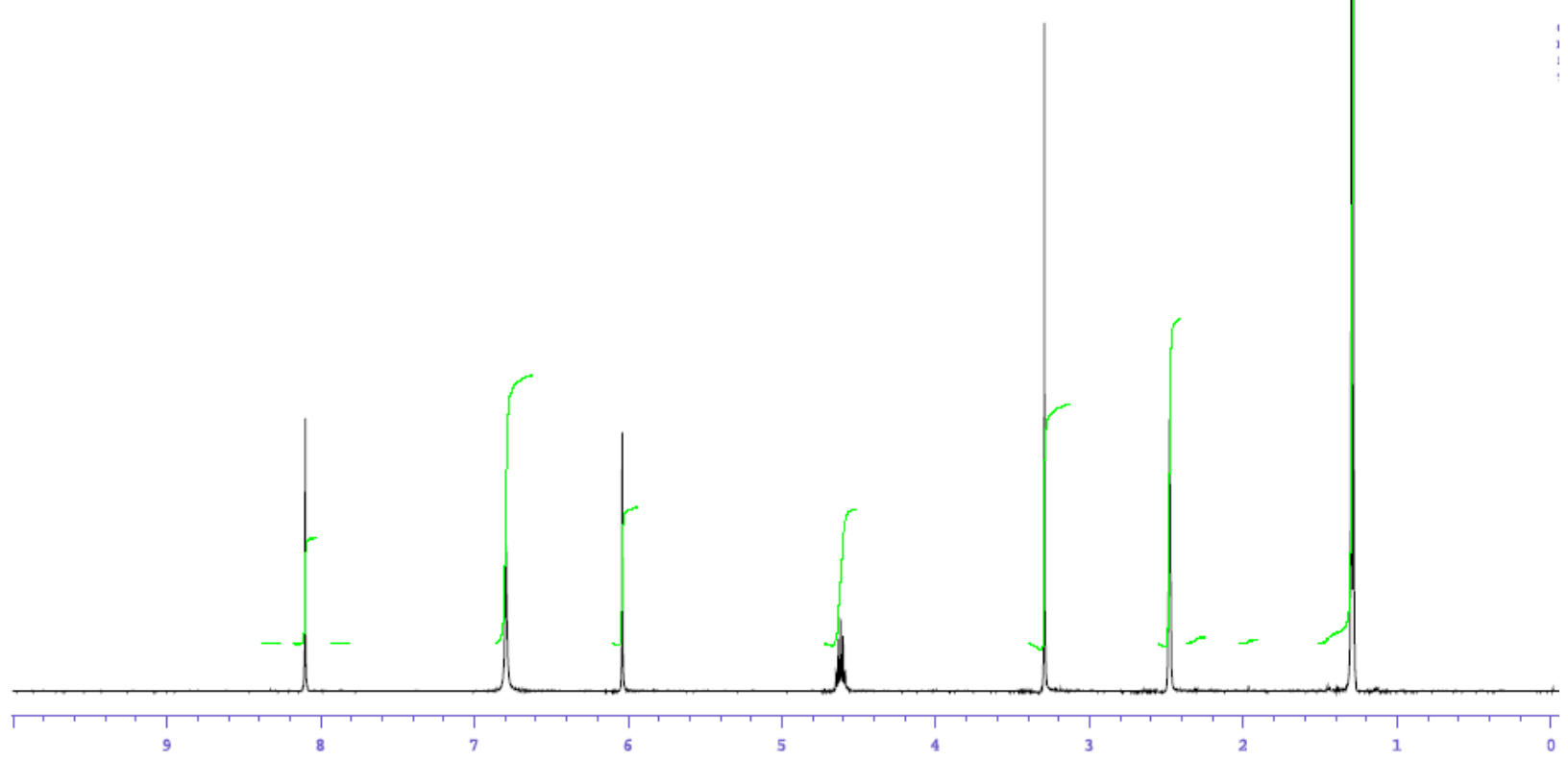


Scheme 2 Synthesis of the key THN intermediates 102, 103 and 104

6-bromo-7-(dimethoxymethyl)-1,2,3,4-tetrahydro-1,8-naphthyridine 99

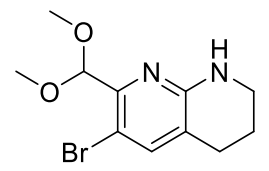

Into a 3 L 4-necked round-bottom flask was placed 7-(dimethoxymethyl)-1,2,3,4-tetrahydro-1,8-naphthyridine (98, $114.6 \mathrm{~g}, 550 \mathrm{mmol})$ in acetonitrile $(2 \mathrm{~L})$. This was followed by the addition of NBS (103 g, $578 \mathrm{~mol})$ in portions with stirring at $25{ }^{\circ} \mathrm{C}$. The resulting solution was stirred for $30 \mathrm{~min}$ at $25{ }^{\circ} \mathrm{C}$. The resulting mixture was concentrated under vacuum and the residue was diluted with $1000 \mathrm{~mL}$ of diethylether. The mixture was washed with $3 \times 100 \mathrm{~mL}$ of ice/water. The aqueous phase was extracted with 2x $100 \mathrm{~mL}$ of diethylether and the organic layers were combined. The resulting mixture was washed with $1 \times 100 \mathrm{~mL}$ of brine, dried over sodium sulfate and concentrated under vacuum to give the title compound as a light yellow solid. LC-MS (method B) tR $0.71 \mathrm{~min}, \mathrm{~m} / \mathrm{z}, 255.0 / 257.0$ (82\%, M-OMe), 287.0/289.0 (100\%, M+H). ${ }^{1} \mathrm{H}-\mathrm{NMR}:\left(400 \mathrm{MHz}, \mathrm{DMSO}-d_{6}\right) \delta 7.31$ (s, 1H, Ar H), $6.82(3, \mathrm{br}, 1 \mathrm{H}, \mathrm{NH}), 5.28(\mathrm{~s}, 1 \mathrm{H}$, $\left.\mathrm{CH}(\mathrm{OMe})_{2}\right), 3.27$ (s, 6H, CH$\left.\left(\mathrm{OCH}_{3}\right)_{2}\right), 3.24-3.19\left(\mathrm{~m}, 2 \mathrm{H}, \mathrm{CH}_{2} \mathrm{CH}_{2} \mathrm{CH}_{2} \mathrm{NH}\right), 2.63\left(\mathrm{t}, 2 \mathrm{H}, J=6.7 \mathrm{~Hz}, \mathrm{CH}_{2} \mathrm{CH}_{2} \mathrm{CH}_{2} \mathrm{NH}\right)$, $1.75-1.67\left(\mathrm{~m}, 2 \mathrm{H}, \mathrm{CH}_{2} \mathrm{CH}_{2} \mathrm{CH}_{2} \mathrm{NH}\right)$.

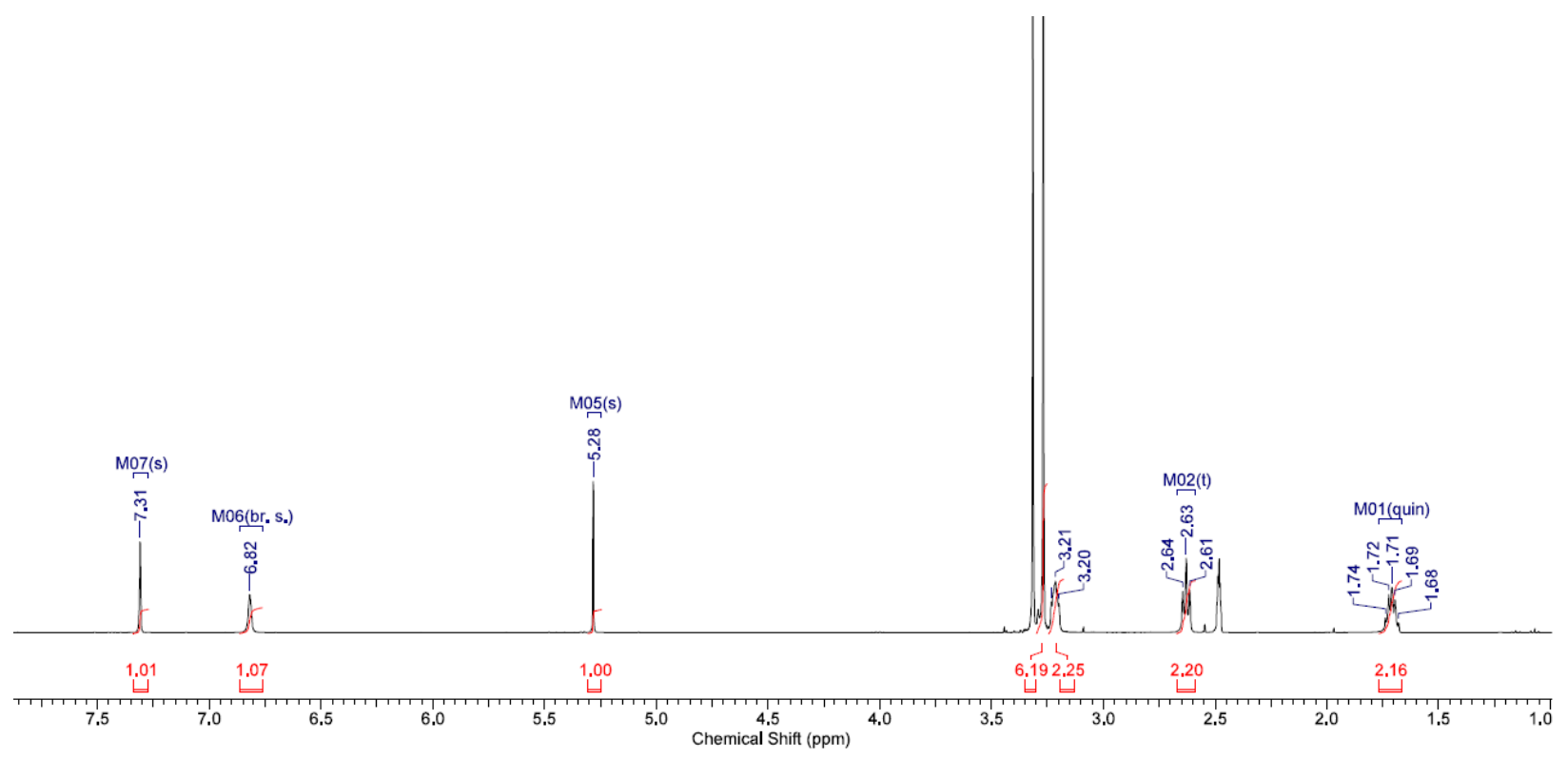


2-(dimethoxymethyl)-5,6,7,8-tetrahydro-1,8-naphthyridine-3-carbaldehyde $\mathbf{1 0 1}$

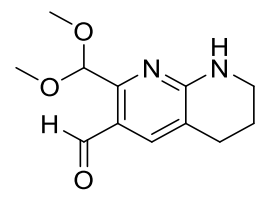

To a solution of 6-bromo-7-(dimethoxymethyl)-1,2,3,4-tetrahydro-1,8-naphthyridine (99, $15.0 \mathrm{~g}, 52.2 \mathrm{mmol}) \mathrm{in}$ THF $(400 \mathrm{~mL})$ at $-78{ }^{\circ} \mathrm{C}$ under argon, was added $\mathrm{MeLi}\left(1.6 \mathrm{M}\right.$ in $\left.\mathrm{Et}_{2} \mathrm{O}, 32.6 \mathrm{~mL}, 52.2 \mathrm{mmol}\right)$, the solution was stirred for $5 \mathrm{~min}$, then $n$ - $\mathrm{BuLi}(1.6 \mathrm{M}$ in hexane, $35.9 \mathrm{~mL}, 57.5 \mathrm{mmol})$ was added slowly and the solution was stirred for $20 \mathrm{~min}$. THF (100 mL) was added to the reaction at $-78{ }^{\circ} \mathrm{C}$. Subsequently, $n$-BuLi (1.6 M in hexane, $\left.49.0 \mathrm{~mL}, 78 \mathrm{mmol}\right) \mathrm{was}$ added and the reaction mixture was stirred for $20 \mathrm{~min}$, then again $n$-BuLi (1.6 $\mathrm{M}$ in hexane, $6.53 \mathrm{~mL}, 10.45 \mathrm{mmol}$ ) was added and the mixture was stirred for $10 \mathrm{~min}$ at $-78^{\circ} \mathrm{C}$. DMF $(2.10 \mathrm{~mL}, 27.2 \mathrm{mmol})$ was added and the reaction mixture was stirred at $-78{ }^{\circ} \mathrm{C}$ for $45 \mathrm{~min}$, then allowed to warm to room temperature, poured into saturated aq. $\mathrm{NH} 4 \mathrm{Cl}$ and extracted twice with DCM. The combined organic phases were dried over $\mathrm{Na}_{2} \mathrm{SO}_{4}$, filtered and evaporated to give the title compound as an orange oil. LC-MS (method A) tR $0.63 \mathrm{~min}, \mathrm{~m} / z, 205.1$ (100\%, M-OMe), 237.2 (95\%, M+H). ${ }^{1} \mathrm{H}-\mathrm{NMR}:\left(600 \mathrm{MHz}, \mathrm{CHCl}_{3}-d_{1}\right) \delta 10.32(\mathrm{~s}, 1 \mathrm{H}, \mathrm{CHO}), 7.76(\mathrm{~s}, 1 \mathrm{H}, \mathrm{Ar} \mathrm{H}), 5.72(\mathrm{~s}, \mathrm{br}, 1 \mathrm{H}, \mathrm{NH}), 5.45(\mathrm{~s}, 1 \mathrm{H}$, $\left.\mathrm{CH}(\mathrm{OMe})_{2}\right), 3.51-3.47\left(\mathrm{~m}, 2 \mathrm{H}, \mathrm{CH}_{2} \mathrm{CH}_{2} \mathrm{CH}_{2} \mathrm{NH}\right), 3.47\left(\mathrm{~s}, 6 \mathrm{H}, \mathrm{CH}\left(\mathrm{OCH}_{3}\right)_{2}\right), 2.76\left(\mathrm{t}, 2 \mathrm{H}, J=6.9 \mathrm{~Hz}_{2} \mathrm{CH}_{2} \mathrm{CH}_{2} \mathrm{CH}_{2} \mathrm{NH}\right)$, $1.97-1.91\left(\mathrm{~m}, 2 \mathrm{H}, \mathrm{CH}_{2} \mathrm{CH}_{2} \mathrm{CH}_{2} \mathrm{NH}\right)$.

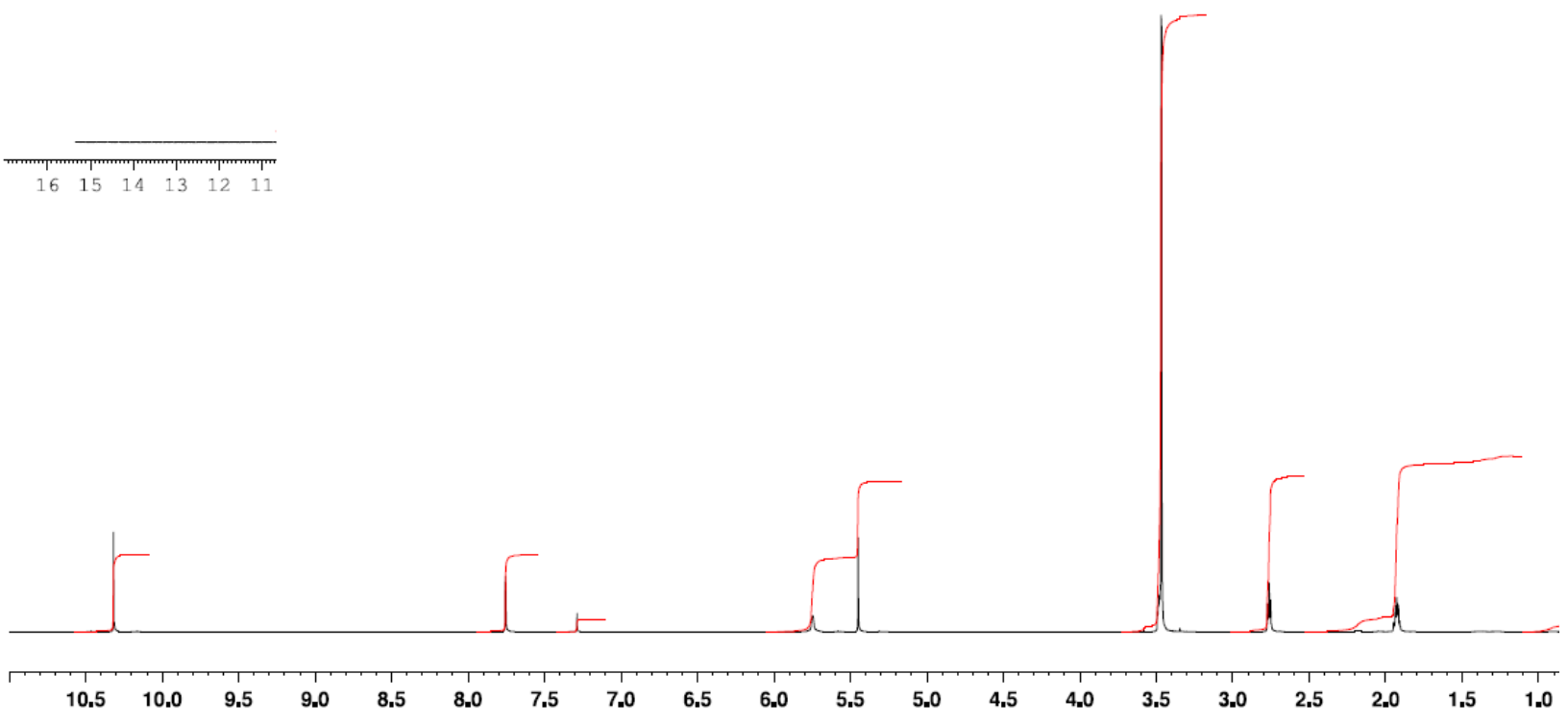


6-(difluoromethyl)-7-(dimethoxymethyl)-1,2,3,4-tetrahydro-1,8-naphthyridine $\mathbf{1 0 2}$

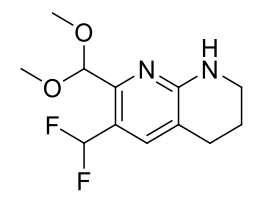

DAST $(4.86 \mathrm{ml}, 23.70 \mathrm{mmol})$ was added drop wise to a solution of 2 -(dimethoxymethyl)-5,6,7,8-tetrahydro-1,8naphthyridine-3-carbaldehyde (101, $2.5 \mathrm{~g}, 8.46 \mathrm{mmol})$ in DCM $(30 \mathrm{~mL})$ at $0{ }^{\circ} \mathrm{C}$. The reaction mixture was stirred for 45 minutes at $0{ }^{\circ} \mathrm{C}$, then for $18 \mathrm{~h}$ at room temperature and partitioned between saturated aqueous $\mathrm{NaHCO}_{3}$ and $\mathrm{DCM}_{\text {, }}$ extracted 3x with DCM, the combined organic layers were dried over $\mathrm{Na}_{2} \mathrm{SO}_{4}$ and evaporated. The residue was preabsorbed onto isolute and purified by normal phase chromatography using a 40 g RediSep silica column, eluting with a gradient from heptane to EtOAc. Product containing fractions were combined and evaporated to give the title compound as a yellow solid. LC-MS (method A) tR $0.79 \mathrm{~min}, \mathrm{~m} / z .227 .1$ (50\%, M-OMe), $259.2(100 \%, \mathrm{M}+\mathrm{H}) .{ }^{1} \mathrm{H}-$ NMR: (400 MHz, DMSO-d6) $\delta 7.38(\mathrm{~s}, 1 \mathrm{H}, \mathrm{Ar} \mathrm{H}), 7.15\left(\mathrm{t}, 1 \mathrm{H}, J=55.8 \mathrm{~Hz}, \mathrm{CHF}_{2}\right), 7.05$ (s, br, $\left.1 \mathrm{H}, \mathrm{Ar} \mathrm{H}\right), 4.95(\mathrm{~s}$, $\left.1 \mathrm{H}, \mathrm{CH}(\mathrm{OMe})_{2}\right), 3.30\left(\mathrm{~s}, 6 \mathrm{H}, \mathrm{CH}\left(\mathrm{OCH}_{3}\right)_{2}\right), 3.30-3.24\left(\mathrm{~m}, 2 \mathrm{H}, \mathrm{CH}_{2} \mathrm{~N}\right), 2.67\left(\mathrm{t}, 2 \mathrm{H}, \mathrm{J}=6.3 \mathrm{~Hz}, \mathrm{ArCH}_{2}\right), 1.71-1.79$ (m, $2 \mathrm{H}, \mathrm{CH}_{2} \mathrm{CH}_{2} \mathrm{~N}$ ).

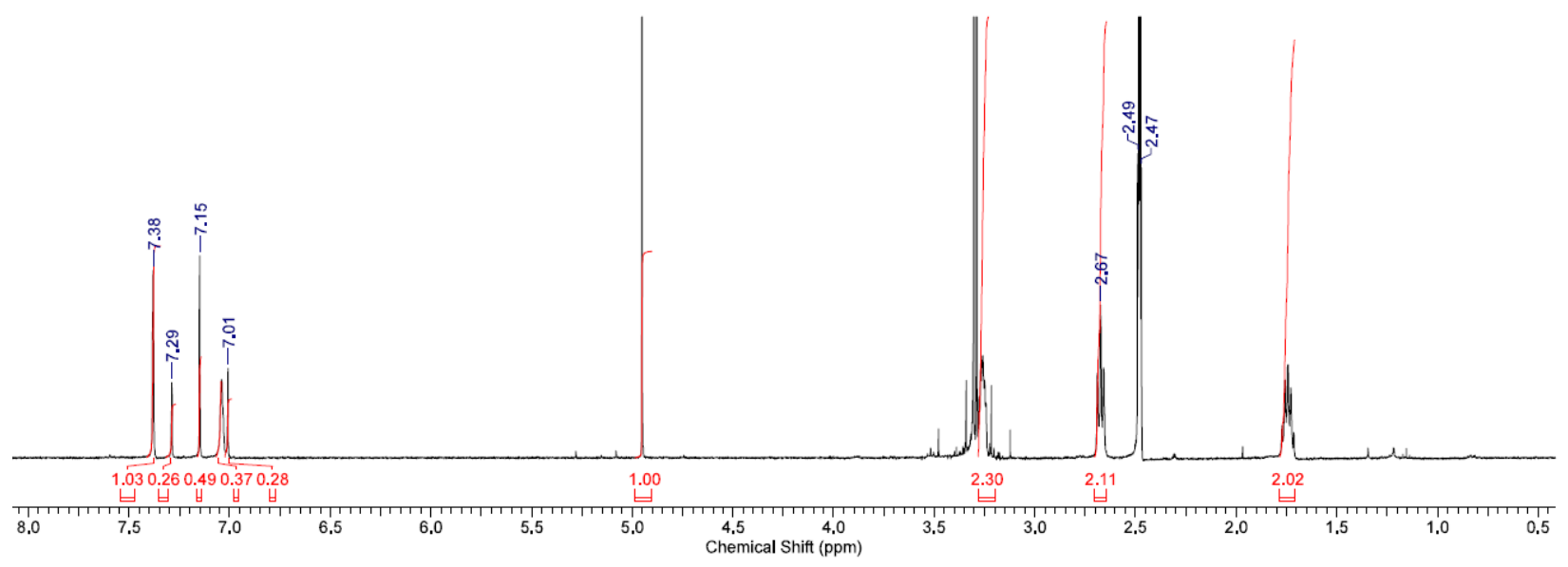


(2-(dimethoxymethyl)-5,6,7,8-tetrahydro-1,8-naphthyridin-3-yl)methanol

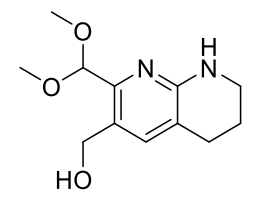

To a solution of 2-(dimethoxymethyl)-5,6,7,8-tetrahydro-1,8-naphthyridine-3-carbaldehyde (101, $10 \mathrm{~g}, 38.2 \mathrm{mmol})$ in $\mathrm{MeOH}(120 \mathrm{~mL})$ and $\mathrm{DCM}(60 \mathrm{~mL})$ was added $\mathrm{NaBH}_{4}(1.16 \mathrm{~g}, 30.6 \mathrm{mmol})$. The reaction mixture was stirred at room temperature for 30 min then slowly quenched with saturated aqueous $\mathrm{NH}_{4} \mathrm{Cl}$ solution and concentrated until the majority of the organic solvents had been removed. The resulting mixture was extracted 4x with DCM. The combined organic layers were dried over $\mathrm{Na}_{2} \mathrm{SO}_{4}$, filtered and evaporated. The crude material was purified by normal phase chromatography usign a $330 \mathrm{~g}$ silica gel cartridge and eluting with a gradient from DCM to DCM/MeOH 20:1 to give the title compound as a yellow oil. LC-MS (method A) tR $0.39 \mathrm{~min}, \mathrm{~m} / z, 239.1(100 \%, \mathrm{M}+\mathrm{H}) .{ }^{1} \mathrm{H}-\mathrm{NMR}:(400 \mathrm{MHz}$, DMSO-d6) $\delta 7.24(\mathrm{~s}, 1 \mathrm{H}, \mathrm{Ar} \mathrm{H}), 6.35(\mathrm{~s}, \mathrm{br}, 1 \mathrm{H}, \mathrm{NH}), 5.05\left(\mathrm{~s}, 1 \mathrm{H}, \mathrm{CH}(\mathrm{OMe})_{2}\right), 4.64(\mathrm{t}, 1 \mathrm{H}, J=5.6 \mathrm{~Hz}, \mathrm{OH}), 4.47(\mathrm{~d}$, $\left.2 \mathrm{H}, J=5.6 \mathrm{~Hz}, \mathrm{ArCH}_{2} \mathrm{O}\right), 3.28\left(\mathrm{~s}, 6 \mathrm{H}, \mathrm{CH}\left(\mathrm{OCH}_{3}\right)_{2}\right), 3.27-3.22\left(\mathrm{~m}, 2 \mathrm{H}, \mathrm{CH}_{2} \mathrm{CH}_{2} \mathrm{NH}\right), 2.66(\mathrm{t}, 2 \mathrm{H}, J=6.2 \mathrm{~Hz}$, $\left.\mathrm{ArCH}_{2} \mathrm{CH}_{2}\right), 1.81-1.73\left(\mathrm{~m}, 2 \mathrm{H}, \mathrm{ArCH}_{2} \mathrm{CH}_{2}\right)$.

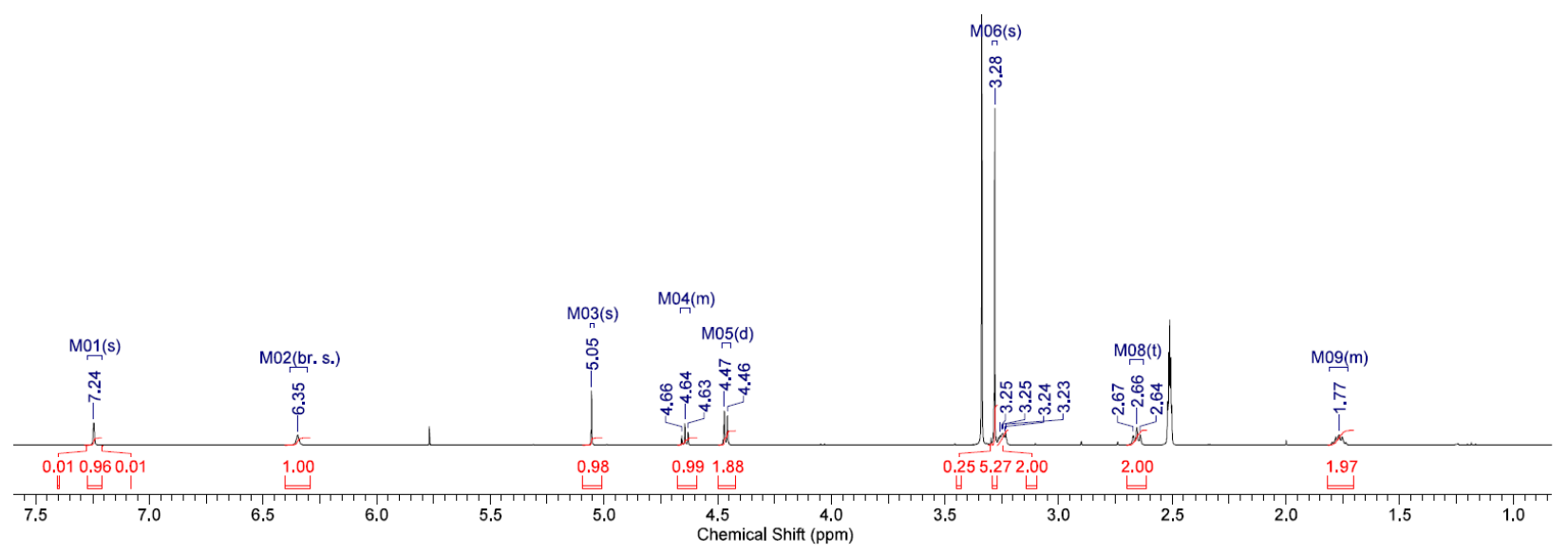


6-(((tert-butyldimethylsilyl)oxy)methyl)-7-(dimethoxymethyl)-1,2,3,4-tetrahydro-1,8-naphthyridine $\mathbf{1 0 3}$

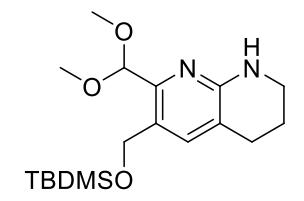

To a solution of (2-(dimethoxymethyl)-5,6,7,8-tetrahydro-1,8-naphthyridin-3-yl)methanol (6.5 g, 27.3 mmol) in DCM $(100 \mathrm{~mL})$ and DMF $(25 \mathrm{~mL})$ at $0{ }^{\circ} \mathrm{C}$ were added DIPEA $(7.15 \mathrm{~mL}, 40.9 \mathrm{mmol})$, tert-butylchlorodimethylsilane (4.93 $\mathrm{g}, 32.7 \mathrm{mmol}$ ) and DMAP (67 $\mathrm{mg}, 0.55 \mathrm{mmol})$. The reaction mixture was then stirred for $1 \mathrm{~h}$ at room temperature, then poured into saturated aq. $\mathrm{NaHCO}_{3}$ and extracted twice with DCM. The combined organic phases were dried over $\mathrm{Na}_{2} \mathrm{SO}_{4}$, filtered and evaporated. The crude material was purified by normal phase chromatography (120 g silica gel cartridge, heptanes/EtOAc 95:5 to 0:100) to give the title compound as a light yellow oil which solidified upon standing to give an off-white powder. LC-MS (method A) tR $1.11 \mathrm{~min}, \mathrm{~m} / z 353.1(100 \%, \mathrm{M}+\mathrm{H}) .{ }^{1} \mathrm{H}-\mathrm{NMR}:(600 \mathrm{MHz}$, DMSO-d6) $\delta 7.16(\mathrm{~s}, 1 \mathrm{H}, \mathrm{Ar} \mathrm{H}), 6.38(\mathrm{~s}, 1 \mathrm{H}, \mathrm{NH}), 4.97\left(\mathrm{~s}, 1 \mathrm{H}, \mathrm{CH}(\mathrm{OMe})_{2}\right), 4.62\left(\mathrm{~s}, 2 \mathrm{H}, \mathrm{ArCH}_{2} \mathrm{O}\right), 3.23-3.17(\mathrm{~m}$, $\left.2 \mathrm{H}, \mathrm{CH}_{2} \mathrm{CH}_{2} \mathrm{NH}\right), 3.22\left(\mathrm{~s}, 6 \mathrm{H}, \mathrm{CH}\left(\mathrm{OCH}_{3}\right)_{2}\right), 2.62-2.58\left(\mathrm{~m}, 2 \mathrm{H}, \mathrm{ArCH}_{2} \mathrm{CH}_{2}\right), 1.73-1.68\left(\mathrm{~m}, 2 \mathrm{H}, \mathrm{ArCH}_{2} \mathrm{CH}_{2}\right), 0.84$ (s, 9H, C(CH3)3), 0.00 (s, 6H, $\left.\mathrm{Si}\left(\mathrm{CH}_{3}\right)_{2}\right)$.

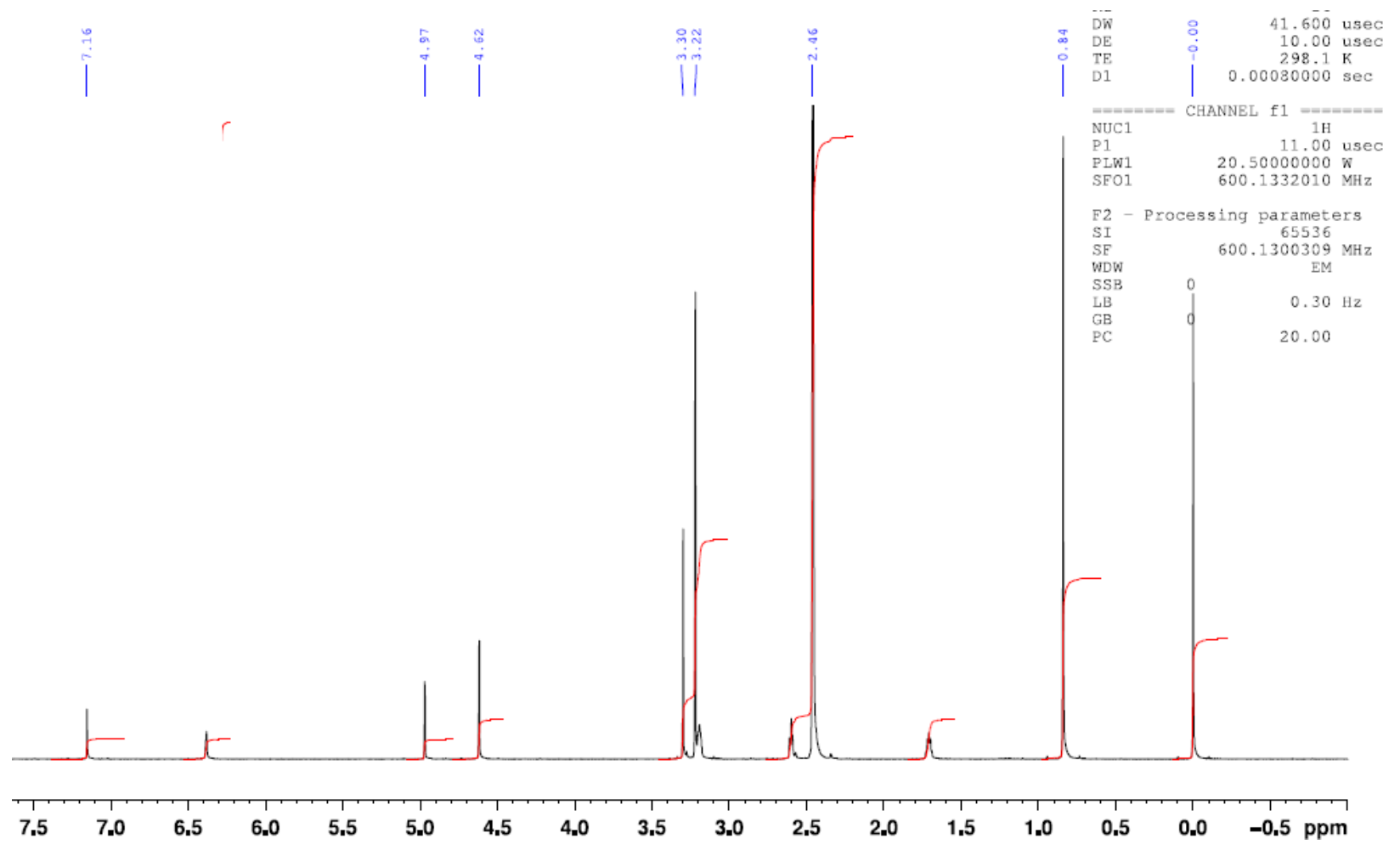


1-(2-(dimethoxymethyl)-5,6,7,8-tetrahydro-1,8-naphthyridin-3-yl)- $N, N$-dimethylmethanamine $\mathbf{1 0 4}$

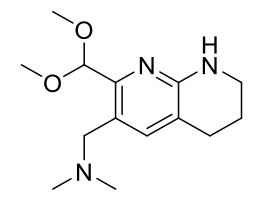

To a solution of 2-(dimethoxymethyl)-5, 6,7,8-tetrahydro-1,8-naphthyridine-3-carbaldehyde (101, $300 \mathrm{mg}, 1.15$ mmol) and dimethylamine $(7.9 \mathrm{M}$ in water, $1.45 \mathrm{~mL}, 11.5 \mathrm{mmol})$ in $\mathrm{DCM}(7 \mathrm{~mL})$ was added sodium triacetoxyborohydride $(486 \mathrm{mg}, 2.29 \mathrm{mmol})$. The reaction mixture was stirred at room temperature for $18 \mathrm{~h}$. Additional dimethylamine $(7.9 \mathrm{M}$ in water, $1.45 \mathrm{~mL}, 11.5 \mathrm{mmol}$ ) was added followed by sodium triacetoxyborohydride (486 mg, $2.29 \mathrm{mmol}$ ) and the reaction mixture stirred room temperature for $8 \mathrm{~h}$. The reaction mixture was then poured into saturated aqueous $\mathrm{NaHCO}_{3}$ and extracted 3x with DCM. The organic layers were then dried over $\mathrm{Na}_{2} \mathrm{SO}_{4}$, filtered and evaporated. The crude material was purified by normal phase chromatography using a $24 \mathrm{~g}$ silica gel cartridge, eluting with a gradient from DCM to DCM/(7 $\mathrm{M} \mathrm{NH}_{3}$ in $\left.\mathrm{MeOH}\right)$ 9:1 to give the title compound as a yellow solid. LC-MS (method A) tR $0.37 \mathrm{~min}, \mathrm{~m} / z 266.2(100 \%, \mathrm{M}+\mathrm{H}) .{ }^{1} \mathrm{H}-\mathrm{NMR}:\left(400 \mathrm{MHz}, \mathrm{DMSO}-d_{6}\right) \delta 7.17$ (s, $\left.1 \mathrm{H}, \mathrm{Ar} \mathrm{H}\right), 6.39$ (s, br, $1 \mathrm{H}, \mathrm{NH}), 5.18\left(\mathrm{~s}, 1 \mathrm{H}, \mathrm{CH}(\mathrm{OMe})_{2}\right), 3.30\left(\mathrm{~s}, 2 \mathrm{H}, \mathrm{ArCH}_{2} \mathrm{~N}\right), 3.26-3.22\left(\mathrm{~m}, 2 \mathrm{H}, \mathrm{CH}_{2} \mathrm{CH}_{2} \mathrm{NH}\right), 3.26\left(\mathrm{~s}, 6 \mathrm{H}, \mathrm{CH}(\mathrm{OCH})_{2}\right)$, $2.67-2.62\left(\mathrm{~m}, 2 \mathrm{H}, \mathrm{ArCH}_{2} \mathrm{CH}_{2}\right), 2.10\left(\mathrm{~s}, 6 \mathrm{H}, \mathrm{N}\left(\mathrm{CH}_{3}\right)_{2}\right), 1.80-1.71\left(\mathrm{~m}, 2 \mathrm{H}, \mathrm{ArCH}_{2} \mathrm{CH}_{2}\right)$.

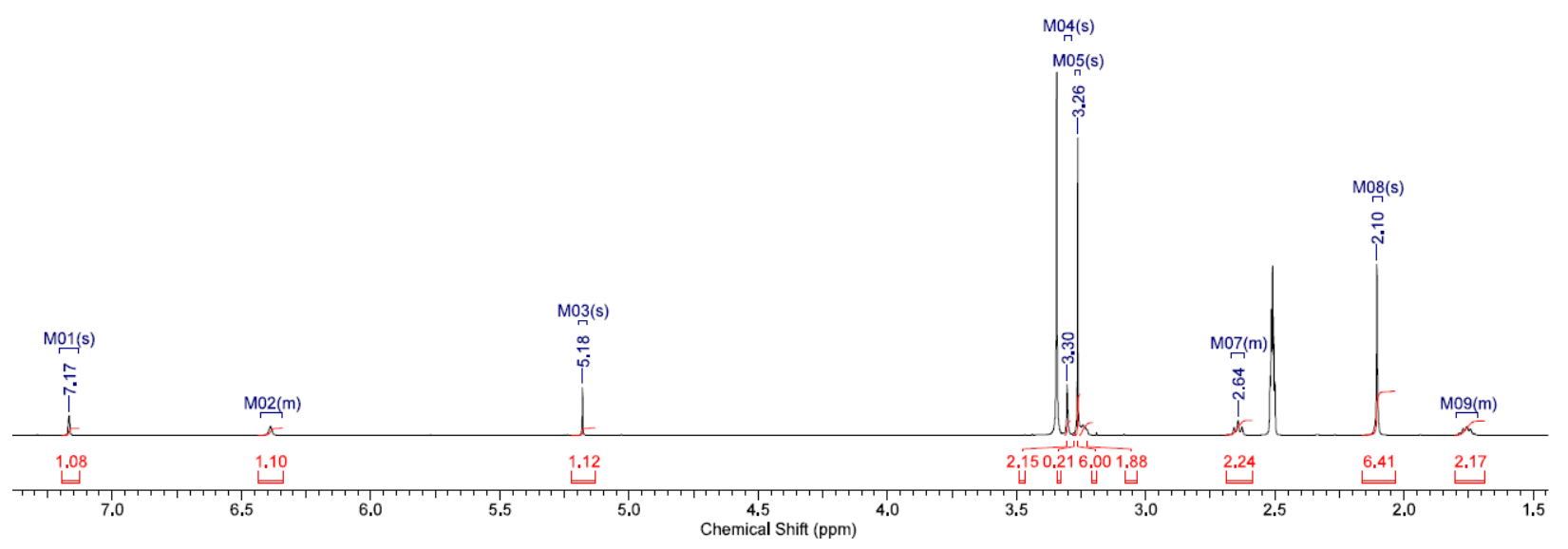


Scheme 3 Synthetic route to compound $\mathbf{6 8}$, using the aza-anion approach for the urea formation

phenyl 6-(((tert-butyldimethylsilyl)oxy)methyl)-7-(dimethoxymethyl)-3,4-dihydro-1,8-naphthyridine-1(2H)carboxylate $\mathbf{1 0 5}$

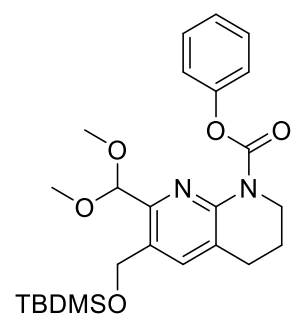

A solution of LiHMDS in THF (1M, $28.6 \mathrm{~mL}, 28.6 \mathrm{mmol})$ was added dropwise over 5 minutes to a solution of 6 (((tert-butyldimethylsilyl)oxy)methyl)-7-(dimethoxymethyl)-1,2,3,4-tetrahydro-1,8-naphthyridine (103, 9.6 g, 27.2 mmol) and diphenyl carbonate $(6.2 \mathrm{~g}, 28.6 \mathrm{mmol})$ in THF $(145 \mathrm{~mL})$ cooled with a dry ice / acetone bath. The reaction mixture was stirred for $30 \mathrm{~min}$ at $-78^{\circ} \mathrm{C}$, the cooling batch removed and the reaction mixture allowed to warm RT. After stirring $2 \mathrm{hr}$ at $\mathrm{RT}$ saturated aqueous $\mathrm{NH}_{4} \mathrm{Cl}$ solution $(200 \mathrm{~mL})$ was added to the clear brown solution and the mixture extracted 2x with DCM. The combined organic layers were dried over $\mathrm{Na}_{2} \mathrm{SO}_{4}$ and evaporated to give a brown oil. The crude product was purified by normal phase chromatography using a $120 \mathrm{~g}$ silica cartridge and eluting with heptane/ethyl acetate 4:1 to give the title compound as pale yellow oil. LC-MS (method A) $\mathrm{t}_{\mathrm{R}} 1.55 \mathrm{~min}, \mathrm{~m} / \mathrm{z} 473.2$ $(100 \%, \mathrm{M}+\mathrm{H}) .{ }^{1} \mathrm{H}-\mathrm{NMR}:\left(600 \mathrm{MHz}, \mathrm{DMSO}-d_{6}\right) \delta 7.60(\mathrm{~s}, 1 \mathrm{H}, \mathrm{Ar} \mathrm{H}), 7.33$ (t, 2H, J = $\left.6.9 \mathrm{~Hz}, \mathrm{Ar} \mathrm{H}\right), 7.17-7.12(\mathrm{~m}$, $3 \mathrm{H}, \mathrm{Ar} \mathrm{H}), 5.09\left(\mathrm{~s}, 1 \mathrm{H}, \mathrm{CH}(\mathrm{OMe})_{2}\right), 4.76\left(\mathrm{~s}, 2 \mathrm{H}, \mathrm{ArCH}_{2} \mathrm{O}\right), 3.75\left(\mathrm{t}, 2 \mathrm{H}, J=6.9 \mathrm{~Hz}, \mathrm{CH}_{2} \mathrm{CH} \mathrm{NH}_{2}\right), 3.19(\mathrm{~s}, 6 \mathrm{H}$, $\left.\mathrm{CH}\left(\mathrm{OCH}_{3}\right)_{2}\right), 2.76\left(\mathrm{t}, 2 \mathrm{H}, J=7.0 \mathrm{~Hz}, \mathrm{ArCH}_{2} \mathrm{CH}_{2}\right), 1.90-1.85\left(\mathrm{~m}, 2 \mathrm{H}, \mathrm{ArCH}_{2} \mathrm{CH}_{2}\right), 0.83\left(\mathrm{~s}, 9 \mathrm{H}, \mathrm{C}(\mathrm{CH})_{3}\right), 0.00(\mathrm{~s}$, $\left.6 \mathrm{H}, \mathrm{Si}\left(\mathrm{CH}_{3}\right)_{2}\right)$.

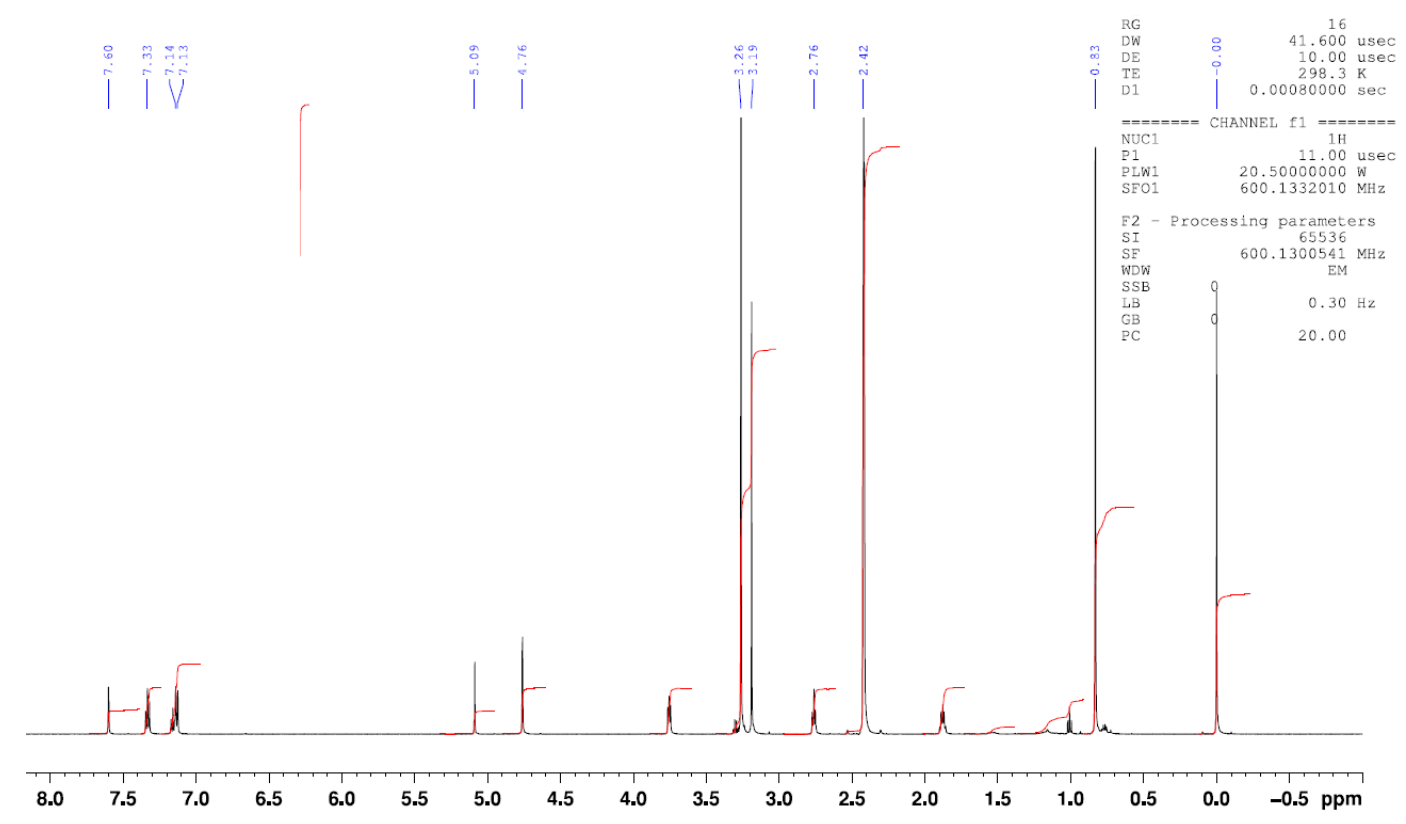


6-(((tert-butyldimethylsilyl)oxy)methyl)- $N$-(5-cyano-4-isopropoxypyridin-2-yl)-7-(dimethoxymethyl)-3,4-dihydro1,8-naphthyridine-1 $(2 H)$-carboxamide

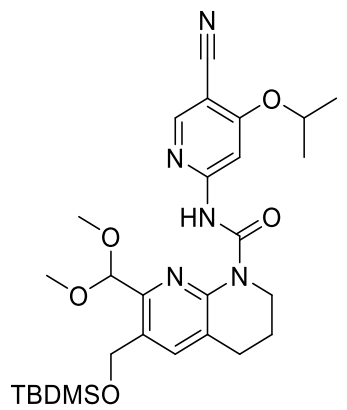

A solution of LiHMDS in THF (1 M, $19.0 \mathrm{~mL}, 19.00 \mathrm{mmol})$ was added dropwise over 20 min to a solution of phenyl 6-(((tert-butyldimethylsilyl)oxy)methyl)-7-(dimethoxymethyl)-3,4-dihydro-1,8-naphthyridine-1(2H)-carboxylate (4.35 g, $9.20 \mathrm{mmol})$ and 6-amino-4-isopropoxynicotinonitrile (97, $1.65 \mathrm{~g}, 9.31 \mathrm{mmol})$ in THF (35 mL) cooled with a dry ice / acetone bath. The reaction mixture was stirred at $-78^{\circ} \mathrm{C}$ for $2.5 \mathrm{~h}$ and then quenched with saturated aqueous $\mathrm{NH}_{4} \mathrm{Cl}$ solution $(40 \mathrm{~mL})$, diluted with water and extracted $3 \mathrm{x}$ with ethyl acetate/heptane 1:1 (20 mL). The combined organic layers were combined, dried over sodium sulfate and evaporated to give an orange oil. The crude product was absorbed onto Isolute and purified by normal phase chromatography using a $120 \mathrm{~g}$ silica column, eluting with a gradient from heptane to heptane/ethyl acetate 8:2 to give the title compound as a white solid. LC-MS (method A) $t_{R}$ $1.67 \mathrm{~min}, \mathrm{~m} / z$ $556.3(100 \%, \mathrm{M}+\mathrm{H}), 554.2(100 \%, \mathrm{M}-\mathrm{H}) .{ }^{1} \mathrm{H}-\mathrm{NMR}:(600 \mathrm{MHz}$, chloroform- $d) \delta 13.90(\mathrm{~s}, 1 \mathrm{H}, \mathrm{C}(\mathrm{O}) \mathrm{NH})$, 8.25 (s, 1H, Ar H), 7.84 (s, 1H, Ar H), 7.63 (s, 1H, ArH), 5.33 (s, 1H, CH(OMe)2), 4.77 (s, 2H, ArCH2O), 4.72 (septet, $1 \mathrm{H}, J=6.1 \mathrm{~Hz}, \mathrm{OCHMe} 2), 3.89-3.95\left(\mathrm{~m}, 2 \mathrm{H}, \mathrm{CH}_{2} \mathrm{CH}_{2} \mathrm{NH}\right), 3.33\left(\mathrm{~s}, 6 \mathrm{H}, \mathrm{CH}\left(\mathrm{OCH}_{3}\right) 2\right), 2.76(\mathrm{t}, 2 \mathrm{H}, J=6.2 \mathrm{~Hz}$, $\left.\mathrm{ArCH}_{2} \mathrm{CH}_{2}\right), 1.85-1.93\left(\mathrm{~m}, 2 \mathrm{H}, \mathrm{ArCH}_{2} \mathrm{CH}_{2}\right), 1.32\left(\mathrm{~d}, 6 \mathrm{H}, J=6.1 \mathrm{~Hz}, \mathrm{OCH}\left(\mathrm{CH}_{3}\right)_{2}\right), 0.83\left(\mathrm{~s}, 9 \mathrm{H}, \mathrm{C}(\mathrm{CH})_{3}\right), 0.00(\mathrm{~s}$, $\left.6 \mathrm{H}, \mathrm{Si}\left(\mathrm{CH}_{3}\right)_{2}\right)$.

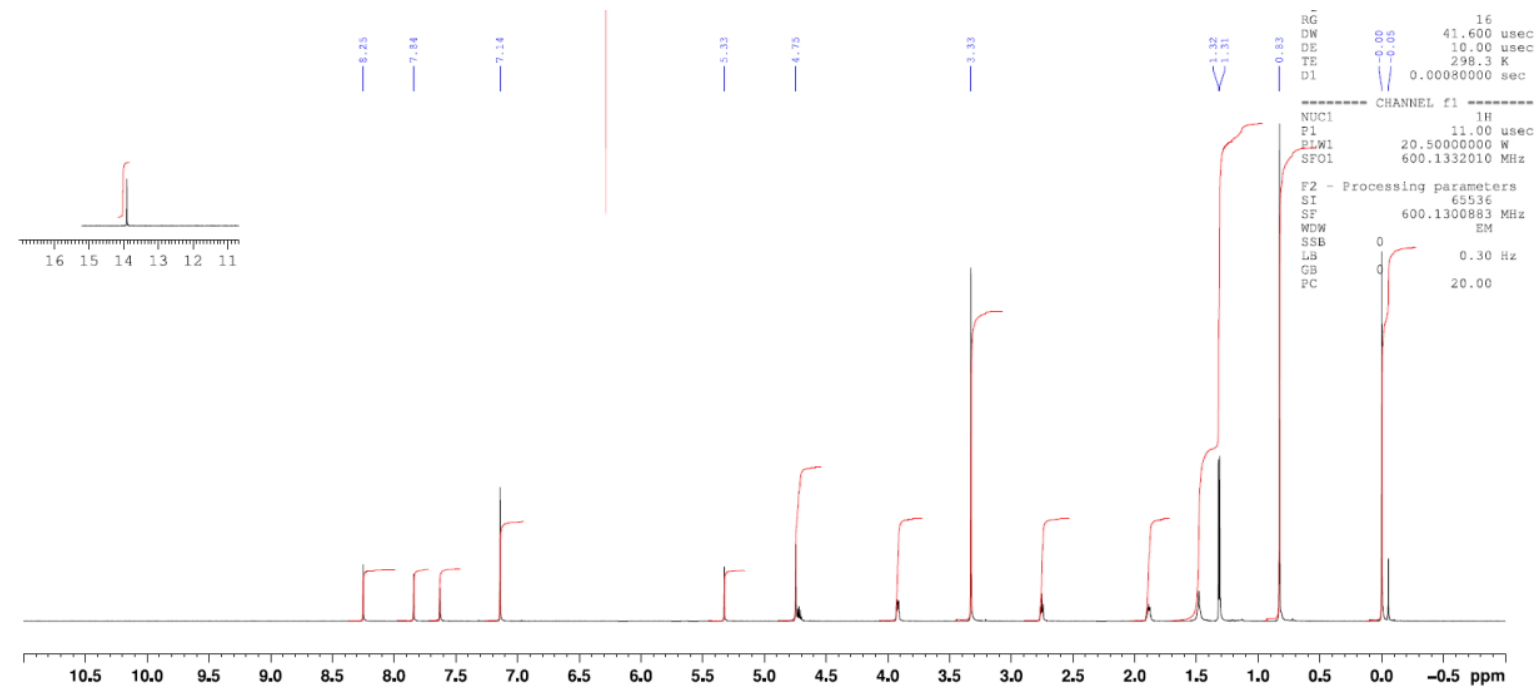


N-(5-cyano-4-isopropoxypyridin-2-yl)-7-(dimethoxymethyl)-6-(hydroxymethyl)-3,4-dihydro-1,8-naphthyridine$\underline{1(2 H) \text {-carboxamide } \mathbf{1 0 6}}$

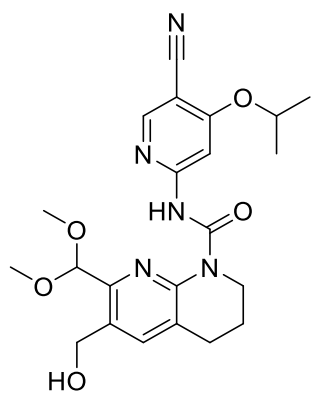

Hydrogen fluoride pyridine $(70 \%, 6.0 \mathrm{~mL}, 46.9 \mathrm{mmol})$ was added dropwise over 5 min to a stirred solution of 6 (((tert-butyldimethylsilyl)oxy)methyl)- $N$-(5-cyano-4-isopropoxypyridin-2-yl)-7-(dimethoxymethyl)-3,4-dihydro1,8-naphthyridine-1(2H)-carboxamide $(12.4 \mathrm{~g}, 22.3 \mathrm{mmol})$ in THF $(115 \mathrm{~mL})$ at RT. The clear yellow solution was stirred for $4 \mathrm{~h}$ at RT, then diluted with saturated $\mathrm{NaHCO}_{3}$ solution $(230 \mathrm{~mL})$, and extracted $3 \mathrm{x}$ with $\mathrm{DCM}(500 \mathrm{~mL})$. The combined organic layers were washed with water $(100 \mathrm{~mL})$, dried over $\mathrm{Na}_{2} \mathrm{SO}_{4}$ and evaporated and heated for 3 $\mathrm{h}$ at $50{ }^{\circ} \mathrm{C}$ under high vacuum to give the title compound as a white solid. LC-MS (method A) $\mathrm{t}_{\mathrm{R}} 1.10 \mathrm{~min}, \mathrm{~m} / \mathrm{z} 442.2$ $(100 \%, \mathrm{M}+\mathrm{H}), 440.1(100 \%, \mathrm{M}-\mathrm{H}), 486.1\left(70 \%, \mathrm{M}+\mathrm{HCO}_{2}^{-}\right) .{ }^{1} \mathrm{H}-\mathrm{NMR}:(600 \mathrm{MHz}$, chloroform- $d) \delta 13.96(\mathrm{~s}, 1 \mathrm{H}$, $\mathrm{C}(\mathrm{O}) \mathrm{NH}), 8.39$ (s, 1H, Ar H), 7.98 (s, 1H, Ar H), 7.59 (s, 1H, ArH), 5.50 (s, 1H, CH(OMe) $), 4.88$ (septet, $1 \mathrm{H}, J=$ $6.1 \mathrm{~Hz}, \mathrm{OCHMe}$ ), 4.74 (s, 2H, $\left.\mathrm{ArCH}_{2} \mathrm{O}\right), 4.09-4.05\left(\mathrm{~m}, 2 \mathrm{H}, \mathrm{CH}_{2} \mathrm{CH}_{2} \mathrm{NH}\right), 3.58\left(\mathrm{~s}, 6 \mathrm{H}, \mathrm{CH}(\mathrm{OCH})_{2}\right), 2.89(\mathrm{t}, 2 \mathrm{H}, J$ $\left.=6.2 \mathrm{~Hz}, \mathrm{ArCH}_{2} \mathrm{CH}_{2}\right), 2.07-2.02\left(\mathrm{~m}, 2 \mathrm{H}, \mathrm{ArCH}_{2} \mathrm{CH}_{2}\right), 1.61(\mathrm{~s}, \mathrm{br}, 1 \mathrm{H}, \mathrm{OH}), 1.48\left(\mathrm{~d}, 6 \mathrm{H}, J=6.1 \mathrm{~Hz}, \mathrm{OCH}(\mathrm{CH})_{2}\right)$.

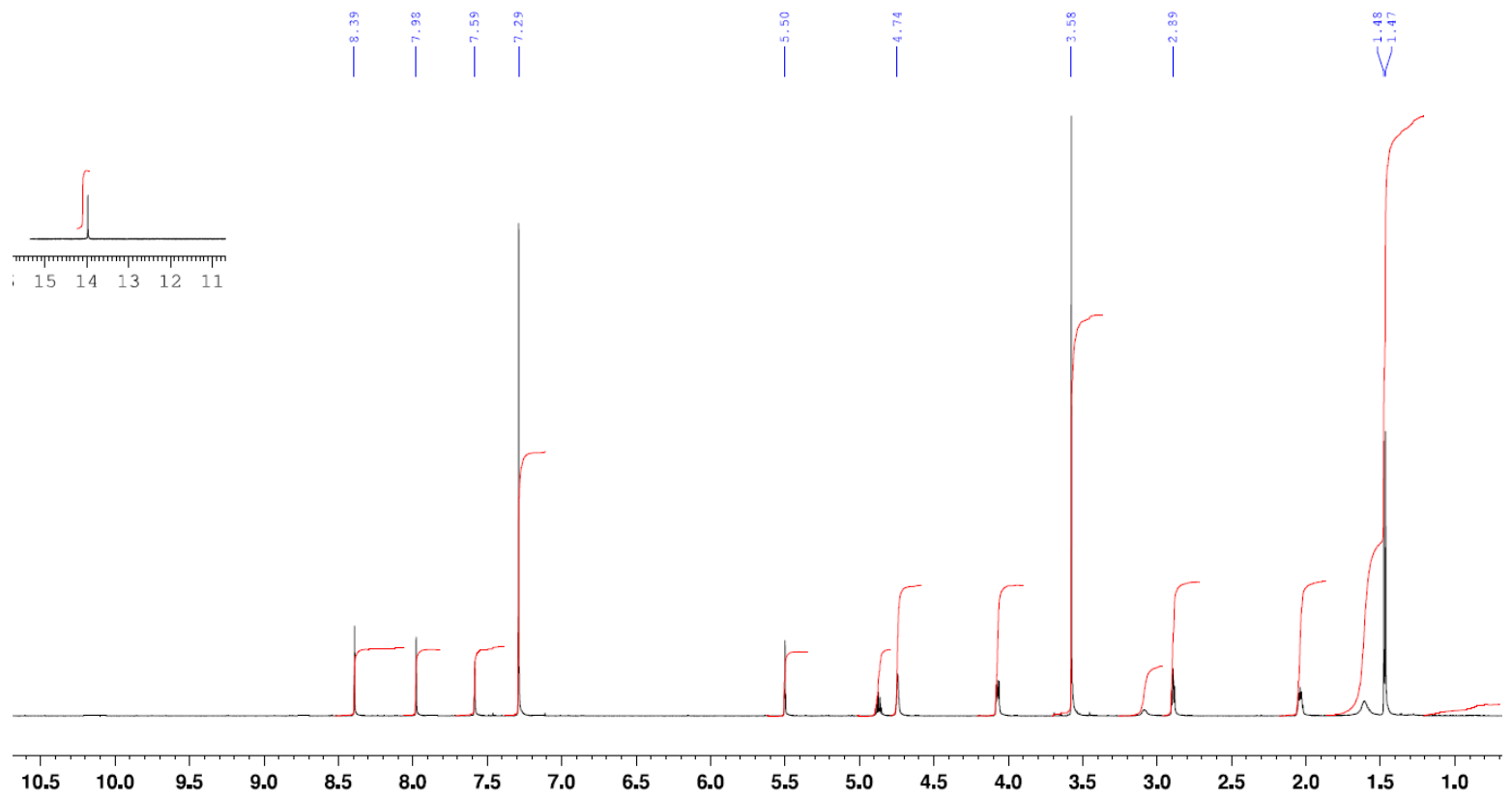


methyl 4-(((8-((5-cyano-4-isopropoxypyridin-2-yl)carbamoyl)-2-(dimethoxymethyl)-5,6,7,8-tetrahydro-1,8naphthyridin-3-yl)methyl)amino)butanoate 107

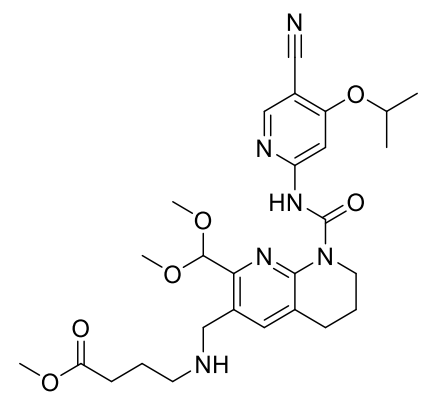

Methanesulfonic anhydride $(6.01 \mathrm{~g}, 34.5 \mathrm{mmol})$ was added dropwise over $5 \mathrm{~min}$ to a solution of $\mathrm{N}$-(5-cyano-4isopropoxypyridin-2-yl)-7-(dimethoxymethyl)-6-(hydroxymethyl)-3,4-dihydro-1,8-naphthyridine-1(2H)carboxamide (7.59 g, $17.19 \mathrm{mmol})$ and Hünigs base $(9 \mathrm{~mL}, 51.7 \mathrm{mmol})$ in DCM $(80 \mathrm{~mL})$ cooled with an ice bath. After stirring for $5 \mathrm{~min}$ the cooling bath was removed and the reaction mixture was allowed to warm to RT. After stirring $2 \mathrm{hr}$ at RT LC/MS indicated the reaction to be complete. The reaction mixture was then used directly in the following step.LC-MS (method A) sample diluted into $\mathrm{MeOH}$ shows the methyl ether $\mathrm{t}_{\mathrm{R}} 1.30 \mathrm{~min}, \mathrm{~m} / \mathrm{z} 456.2(100 \%$, $\mathrm{M}+\mathrm{H}), 454.2(100 \%, \mathrm{M}-\mathrm{H})$.

The above reaction mixture was added dropwise over $30 \mathrm{~min}$ to a suspension of methyl 4-aminobutyrate hydrochloride (13.22 g, $86 \mathrm{mmol})$, potassium iodide $(3.13 \mathrm{~g}, 18.86 \mathrm{mmol})$ and Hünig's base $(20 \mathrm{~mL}, 115 \mathrm{mmol})$ in THF (100 mL) which had been stirred for $1 \mathrm{hr}$ at RT prior to the addition. The reaction mixture was stirred for $22 \mathrm{hr}$ at which point LC/MS indicated that a proportion of the reaction mixture was the benzylic chloride \{method A: $\mathrm{t}_{\mathrm{R}} 1.36 \mathrm{~min}, \mathrm{~m} / \mathrm{z}$ 460.3/462.3 (100\%, M+H), 458.2/460.2 (M-H) \}. Additional methyl 4-aminobutyrate hydrochloride (8.04 g, 52.3 $\mathrm{mmol}$ ) and Hünig's base $(27 \mathrm{~mL}, 155 \mathrm{mmol})$ were added and the suspension heated to $40{ }^{\circ} \mathrm{C}$ for $18 \mathrm{hr}$. The reaction mixture was concentrated to remove the bulk of the THF and diluted with DCM (100 mL) and a saturated solution of $\mathrm{NaHCO}_{3}(100 \mathrm{~mL})$. The mixture was extracted $4 \mathrm{x}$ with DCM $(100 \mathrm{~mL})$, the combined organic phases dried over $\mathrm{Na}_{2} \mathrm{SO}_{4}$, filtered and concentrated to a viscous red oil. The crude product was purified by medium pressure normal phase chromatography, loading as a DCM solution then eluting with DCM followed by a gradient up to 5\% $\mathrm{MeOH}$ in DCM over 40 min to give the title compound as a yellow solid which contains 5\% of the cyclised lactam (following step, tR $1.14 \mathrm{~min}$ ). LC-MS (method A) tR $0.93 \mathrm{~min}, \mathrm{~m} / \mathrm{z} 541.4$ (100\%, M+H), 539.2 (100\%, M-H). ${ }^{1} \mathrm{H}$ NMR (400 MHz, DMSO-d6) $\delta 14.00(\mathrm{~s}, 1 \mathrm{H}, \mathrm{C}(\mathrm{O}) \mathrm{NH}), 8.58(\mathrm{~s}, 1 \mathrm{H}, \mathrm{Ar} \mathrm{H}), 7.96(\mathrm{~s}, 1 \mathrm{H}, \operatorname{Ar} \mathrm{H}), 7.76(\mathrm{~s}, 1 \mathrm{H}, \operatorname{Ar} \mathrm{H}), 5.55(\mathrm{~s}, 1 \mathrm{H}$, $\left.\mathrm{CH}(\mathrm{OMe})_{2}\right), 4.84(\mathrm{~s}, 1 \mathrm{H}$, septet, $J=7.1 \mathrm{~Hz}, \mathrm{OCHMe}), 3.97-3.92\left(\mathrm{~m}, 2 \mathrm{H}, \mathrm{CH}_{2} \mathrm{CH}_{2} \mathrm{NH}\right), 3.75\left(\mathrm{~s}, 2 \mathrm{H}, \mathrm{ArCH} \mathrm{N}_{2}\right), 3.58$ (s, $\left.3 \mathrm{H}, \mathrm{OCH}_{3}\right), 3.39-3.30\left(\mathrm{~m}, 2 \mathrm{H}, \mathrm{ArCH}_{2} \mathrm{CH}_{2}\right), 3.36\left(\mathrm{~s}, 6 \mathrm{H}, \mathrm{CH}\left(\mathrm{OCH}_{3}\right)_{2}\right), 2.85-2.81\left(\mathrm{~m}, 2 \mathrm{H}, \mathrm{ArCH}_{2} \mathrm{CH}_{2}\right), 2.39-$ $2.34\left(\mathrm{t}, 2 \mathrm{H}, J=6.9 \mathrm{~Hz}, \mathrm{CH}_{2} \mathrm{CO}_{2} \mathrm{Me}\right), 1.71-1.64\left(\mathrm{~m}, 2 \mathrm{H}, \mathrm{ArCH}_{2} \mathrm{CH}_{2}\right), 1.96-1.89\left(\mathrm{~m}, 2 \mathrm{H}, \mathrm{CH}_{2} \mathrm{CH}_{2} \mathrm{CO}_{2} \mathrm{Me}\right), 1.40$ (d, $\left.6 \mathrm{H}, J=7.1 \mathrm{~Hz}, \mathrm{OCH}\left(\mathrm{CH}_{3}\right)_{2}\right)$. Amide $\mathrm{NH}$ unassigned. 


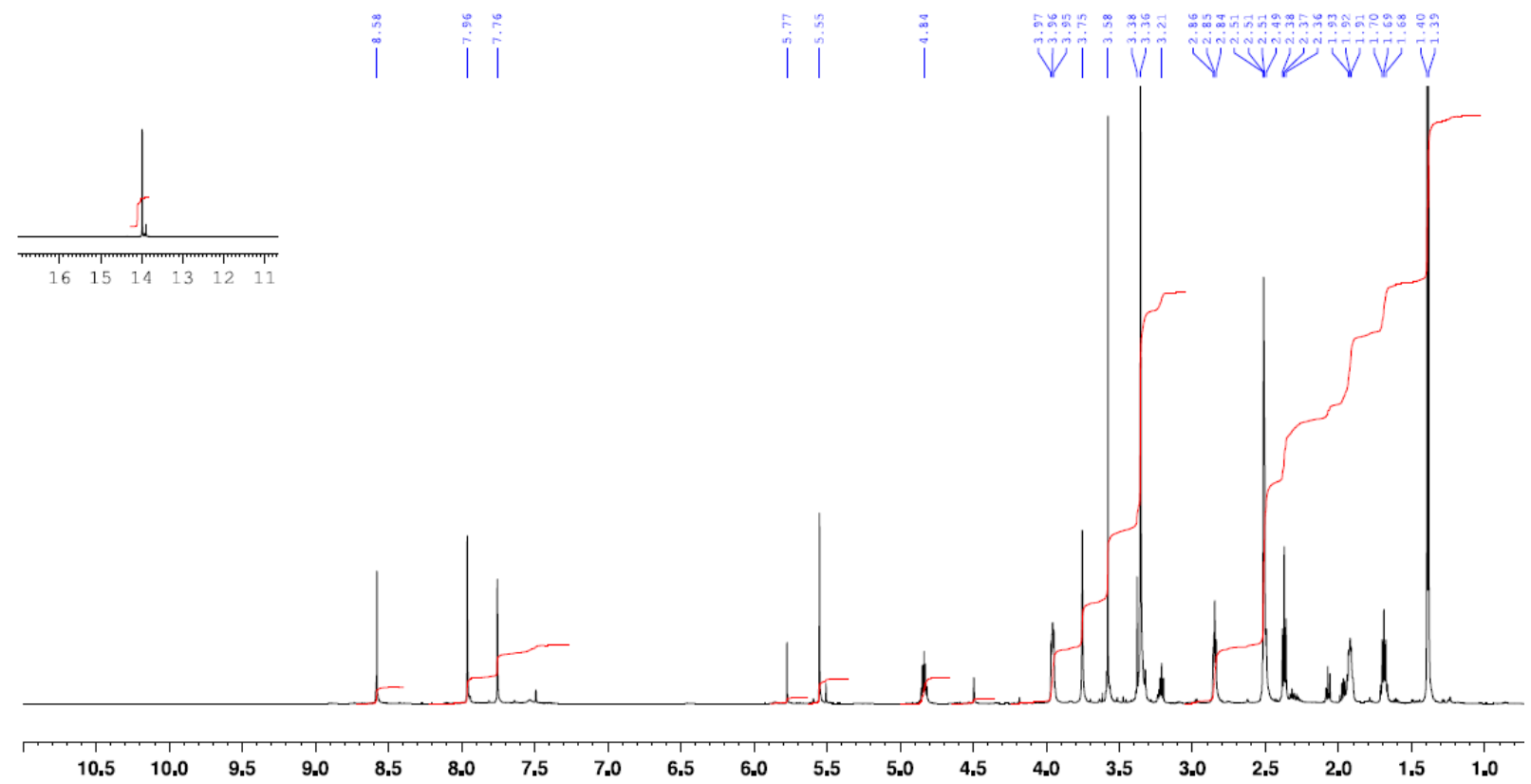


N-(5-cyano-4-isopropoxypyridin-2-yl)-7-(dimethoxymethyl)-6-((2-oxopyrrolidin-1-yl)methyl)-3,4-dihydro-1,8naphthyridine-1 $(2 H)$-carboxamide

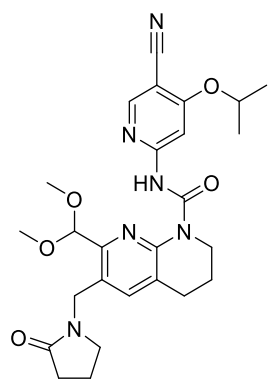

A solution of methyl 4-(((8-((5-cyano-4-isopropoxypyridin-2-yl)carbamoyl)-2-(dimethoxymethyl)-5,6,7,8tetrahydro-1,8-naphthyridin-3-yl)methyl)amino)butanoate (107, $5.8 \mathrm{~g}, 95 \%, 10.19 \mathrm{mmol})$ and triethylamine (1.55 g, $15.29 \mathrm{mmol})$ in anhydrous 1,4 -dioxane $(200 \mathrm{~mL})$ was heated at $90{ }^{\circ} \mathrm{C}$ for $24 \mathrm{hr}$ under a positive pressure of argon. The cooled reaction mixture was concentrated to a viscous red oil. The crude product was purified by normal phase chromatography (120 g silica column), loading as a DCM solution then eluting with a gradient up to $3 \% \mathrm{MeOH}$ in DCM over $50 \mathrm{~min}$. Product containing were combined, evaporated and then sonicated with ethyl acetate (50 $\mathrm{mL})$ to give the title compound as a white solid. LC-MS (method A) tR $1.14 \mathrm{~min}, \mathrm{~m} / \mathrm{z}, 509.2(100 \%, \mathrm{M}+\mathrm{H}), 507.1(100 \%, \mathrm{M}-$ H). ${ }^{1} \mathrm{H}$ NMR (400 MHz, DMSO-d6) $\delta 13.90$ (s, 1H, C(O)NH), 8.59 (s, 1H, Ar H), 7.96 (s, 1H, Ar H), 7.49 (s, $1 \mathrm{H}, \mathrm{Ar}$ H), $5.51(\mathrm{~s}, 1 \mathrm{H}, \mathrm{CH}(\mathrm{OMe}) 2), 4.84(\mathrm{~s}, 1 \mathrm{H}$, septet, $J=7.1 \mathrm{~Hz}, \mathrm{OCHMe}), 4.50\left(\mathrm{~s}, 2 \mathrm{H}, \operatorname{ArCH} \mathrm{H}_{2}\right), 3.99-3.94(\mathrm{~m}, 2 \mathrm{H}$, $\left.\mathrm{ArCH}_{2} \mathrm{CH}_{2}\right), 3.38\left(\mathrm{~s}, 6 \mathrm{H}, \mathrm{CH}\left(\mathrm{OCH}_{3}\right)_{2}\right), 3.25-3.20\left(\mathrm{~m}, 2 \mathrm{H}, \mathrm{CH}_{2} \mathrm{NCO}\right), 3.18-3.16\left(\mathrm{~m}, 2 \mathrm{H}, \mathrm{CH}_{2} \mathrm{CH} \mathrm{HCO}_{2}\right), 2.87-$ $2.79\left(\mathrm{~m}, 2 \mathrm{H}, \mathrm{ArCH}_{2} \mathrm{CH}_{2}\right), 2.34-2.27\left(\mathrm{t}, 2 \mathrm{H}, \mathrm{J}=6.9 \mathrm{~Hz}, \mathrm{CH}_{2} \mathrm{CH}_{2} \mathrm{C}(\mathrm{O}) \mathrm{N}\right), 1.96-1.88\left(\mathrm{~m}, 2 \mathrm{H}, \mathrm{CH}_{2} \mathrm{CH}_{2} \mathrm{Ar}\right), 1.40(\mathrm{~d}$, $\left.6 \mathrm{H}, J=7.1 \mathrm{~Hz}, \mathrm{OCH}\left(\mathrm{CH}_{3}\right)_{2}\right)$.

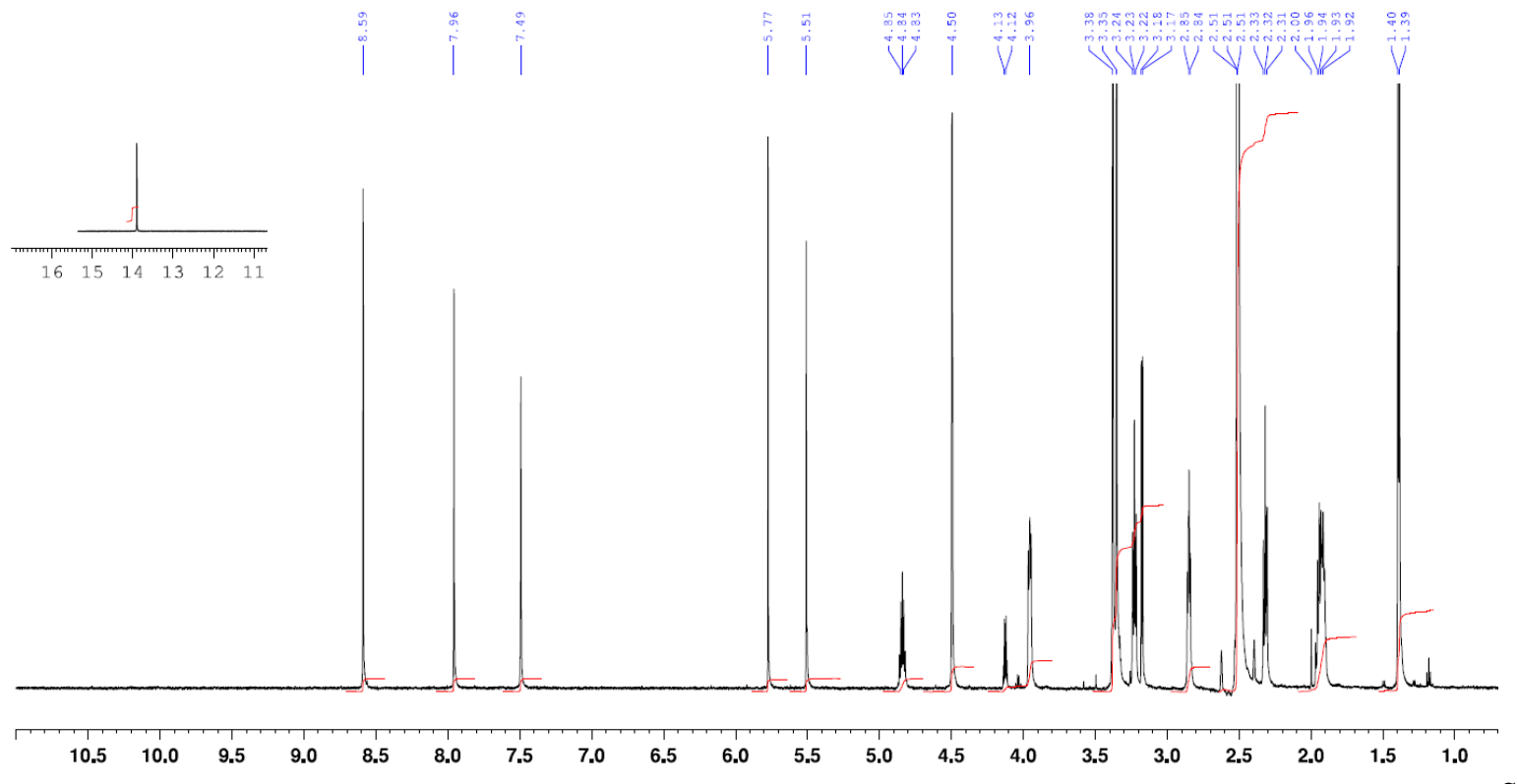




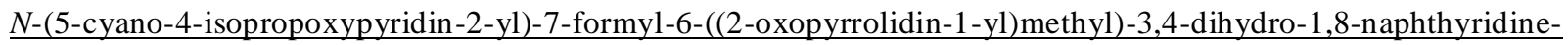
$1(2 H)$-carboxamide 68

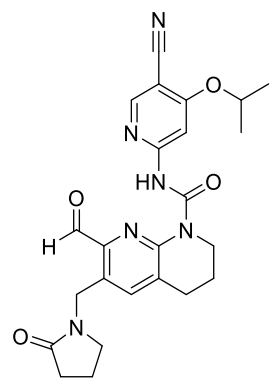

Water $(25 \mathrm{~mL})$ followed by concentrated hydrochloric acid $(4.5 \mathrm{~mL}, 151 \mathrm{mmol})$ were added to a stirred solution of $N$-(5-cyano-4-isopropoxypyridin-2-yl)-7-(dimethoxymethyl)-6-((2-oxopyrrolidin-1-yl)methyl)-3,4-dihydro-1,8naphthyridine-1 $(2 \mathrm{H})$-carboxamide $(5.15 \mathrm{~g}, 10.13 \mathrm{mmol})$ in THF $(80 \mathrm{~mL})$ at room temperature. The reaction mixture was stirred at room temperature for $2 \mathrm{hr}$ then diluted with DCM $(250 \mathrm{~mL})$ followed by the slow addition of saturated aqueous $\mathrm{NaHCO}_{3}(300 \mathrm{~mL})$ (CAUTION: vigorous gas evolution!). Further solid $\mathrm{NaHCO}_{3}$ was added until the water phase became basic. The mixture was extracted with 4x with DCM (150 mL), the combined organic layers dried over $\mathrm{Na}_{2} \mathrm{SO}_{4}$ and evaporated to give a white soid. EtOAc $(100 \mathrm{~mL})$ was added to the crude product, the suspension refluxed for 30 minutes, sonnicated for $15 \mathrm{~min}$ then heated to reflux again for $10 \mathrm{~min}$. The resulting suspension was cooled and stood at $4{ }^{\circ} \mathrm{C}$ for $18 \mathrm{hr}$, filtered and the solid washed with a mixture of ethyl acetate/pentane, $1: 1$. The solid was dried under vacuum at $60{ }^{\circ} \mathrm{C}$ for $18 \mathrm{hr}$ to give the title compound as a white crystaline solid. mp $197{ }^{\circ} \mathrm{C}$ (DSC). LC-MS (method A) sample prepared in $\mathrm{CH}_{3} \mathrm{CN}$ tR $1.08 \mathrm{~min}, \mathrm{~m} / z$ 463.1 (100\%, M+H), $461.1(100 \%, \mathrm{M}-\mathrm{H}) .{ }^{1} \mathrm{H} \mathrm{NMR}(400$ MHz, DMSO-d6) $\delta 13.82$ (s, 1H, C(O)NH), 10.12 (s, 1H, ArC(O)H), 8.59 (s, 1H, Ar H), 7.95 (s, $1 \mathrm{H}, \operatorname{Ar} \mathrm{H}), 7.64(\mathrm{~s}$, 1H, Ar H), 4.85 (septet, $1 \mathrm{H}, J=7.1 \mathrm{~Hz}, \mathrm{OCHMe}$ ), $4.76\left(\mathrm{~s}, 2 \mathrm{H}, \mathrm{ArCH}_{2} \mathrm{~N}\right), 4.01-3.96\left(\mathrm{~m}, 2 \mathrm{H}, \mathrm{ArCH}_{2} \mathrm{CH}_{2}\right), 3.31-$ $3.27(\mathrm{~m}, 2 \mathrm{H}, \mathrm{CH} 2 \mathrm{NCO}), 2.97-2.93\left(\mathrm{~m}, 2 \mathrm{H}, \mathrm{CH}_{2} \mathrm{CH}_{2} \mathrm{NCO}\right), 2.33\left(\mathrm{t}, 2 \mathrm{H}, J=7.0 \mathrm{~Hz}, \mathrm{ArCH} \mathrm{CH}_{2}\right), 2.01-1.91(\mathrm{~m}, 4 \mathrm{H}$, $\mathrm{CH}_{2} \mathrm{CH}_{2} \mathrm{C}(\mathrm{O}) \mathrm{N}$ and $\left.\mathrm{CH}_{2} \mathrm{CH}_{2} \mathrm{Ar}\right), 1.40\left(\mathrm{~d}, 6 \mathrm{H}, J=7.1 \mathrm{~Hz}, \mathrm{OCH}\left(\mathrm{CH}_{3}\right)_{2}\right) .{ }^{13} \mathrm{C} \mathrm{NMR}\left(101 \mathrm{MHz}, \mathrm{DMSO}-d_{6}\right) \delta 191.72$, 174.66, 165.95, 156.80, 153.83, 152.05, 150.08, 143.03, 139.31, 129.04, 128.89, 115.07, 96.37, 94.16, 72.26, 46.70, 43.46, 40.54, 30.05, 27.47, 21.23, 20.20, 17.48. Anal. Calcd for $\mathrm{C}_{24} \mathrm{H}_{26} \mathrm{~N}_{6} \mathrm{O}_{4}$ : C, 62.33; H, 5.67; N, 18.17. Found: C, $62.2 ; \mathrm{H}, 5.7 ; \mathrm{N}, 18.0$. 
$\underline{X-R a y ~ p o w d e r ~ d i f f r a c t i o n ~ p a t t e r n ~ f o r ~} \mathbf{6 8}$

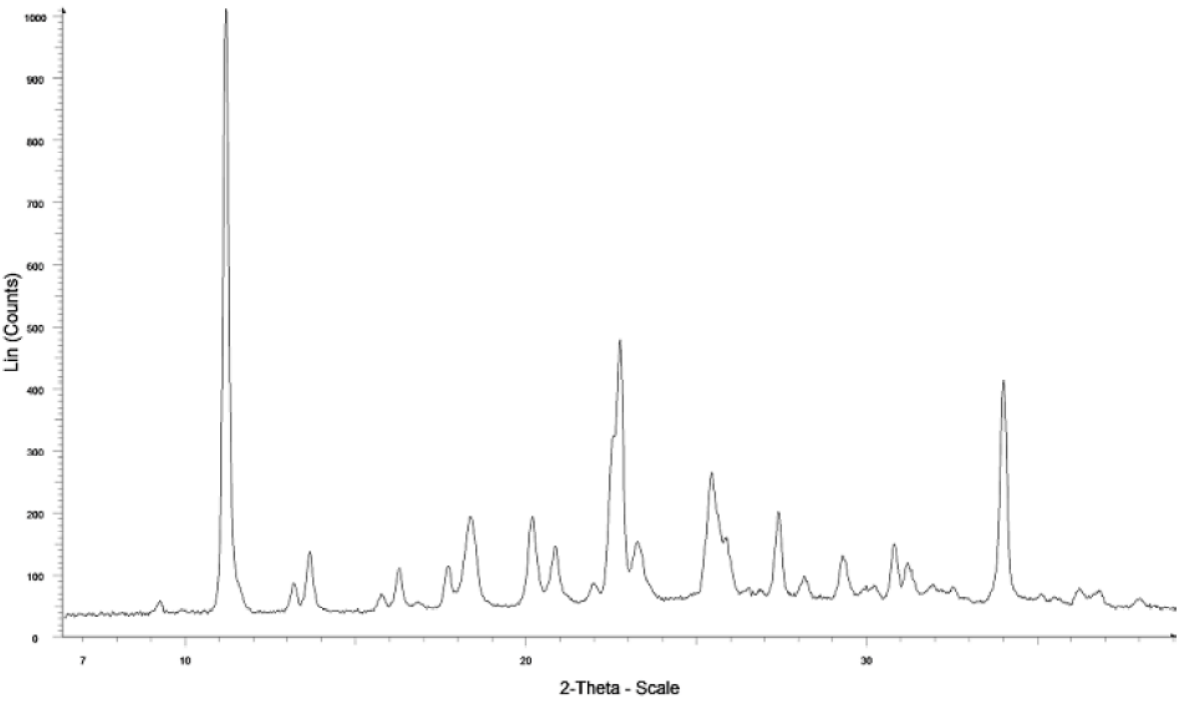

\section{$\underline{\text { LC/MS (Method A) } 68}$}

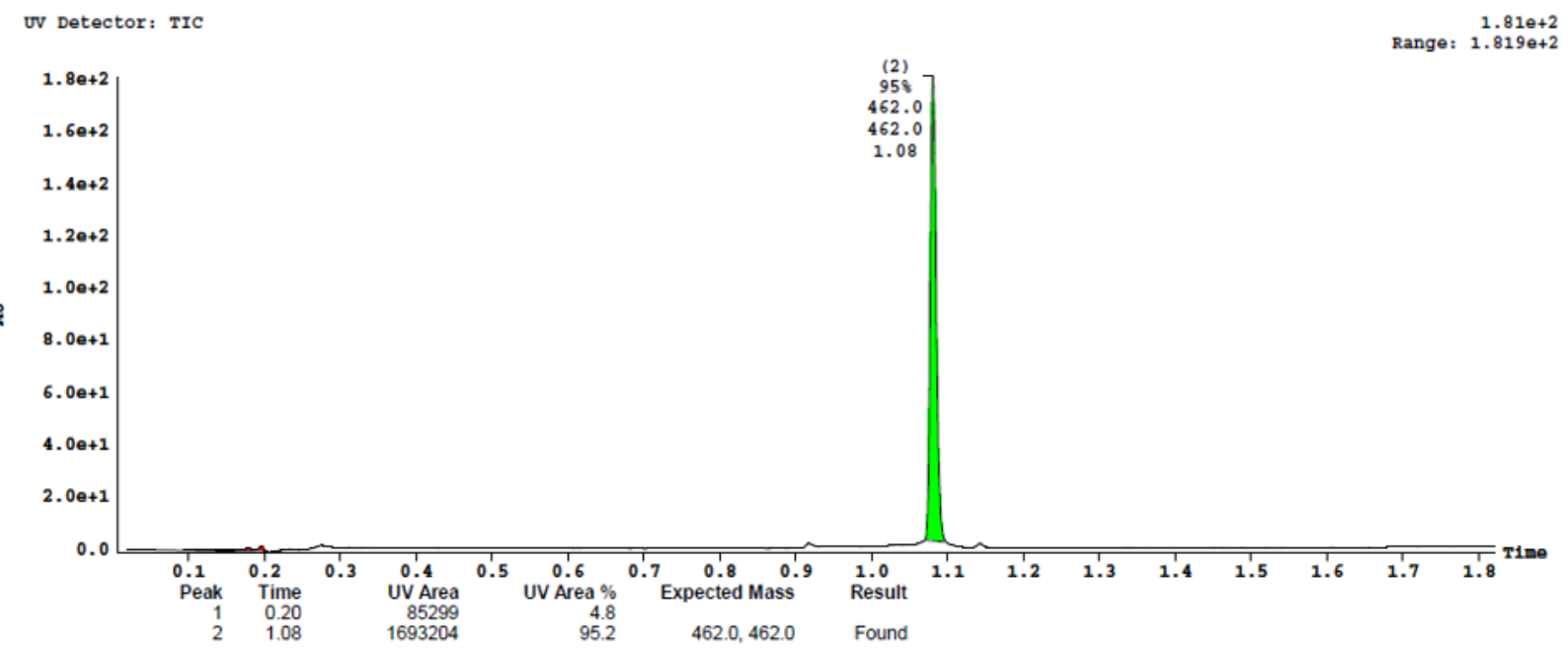



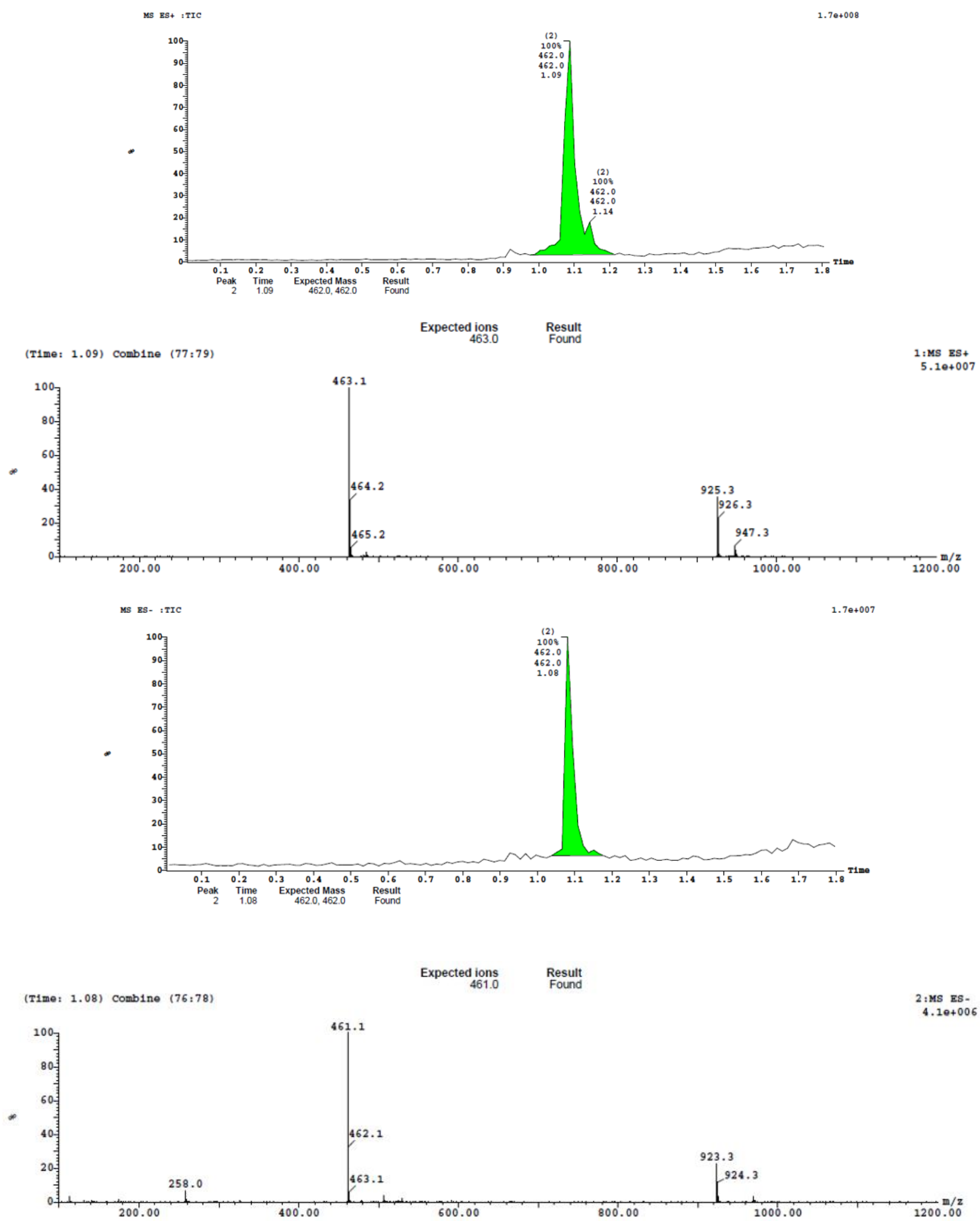


\section{LC/MS (Method C) 68}

3: UV Detector: TAC: Wavelength Range: (210 - 450)

$5.36 e+1$
Range: $5.692 e+1$

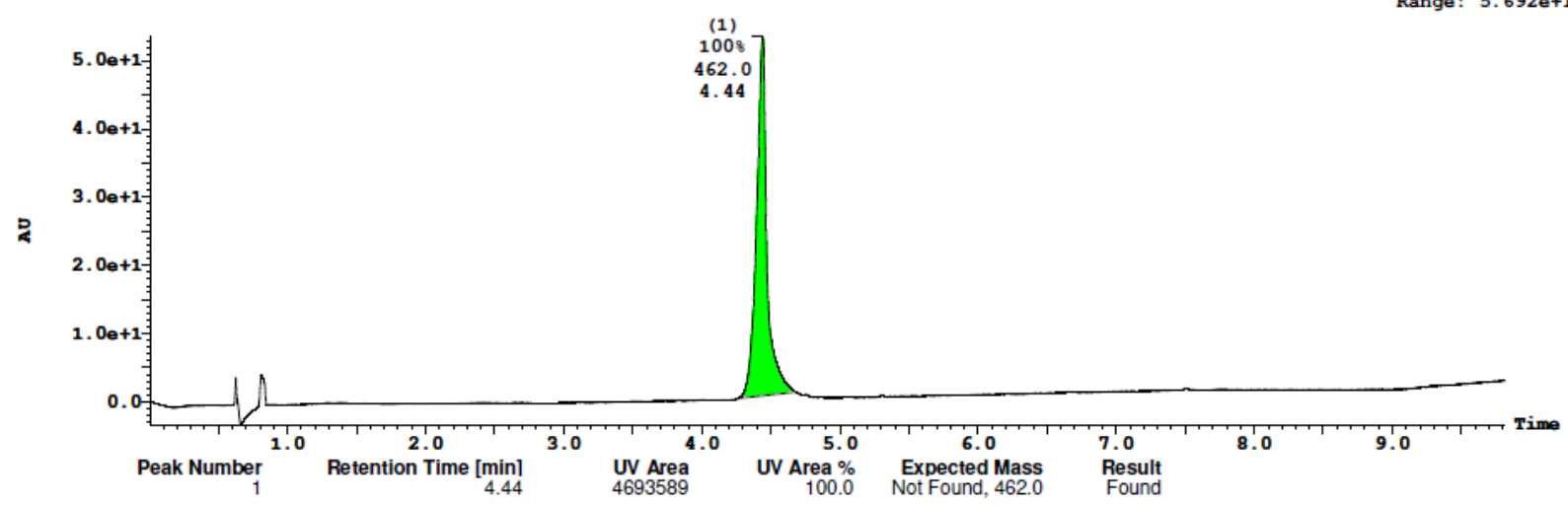

(Time: 4.44) Combine (533:535)

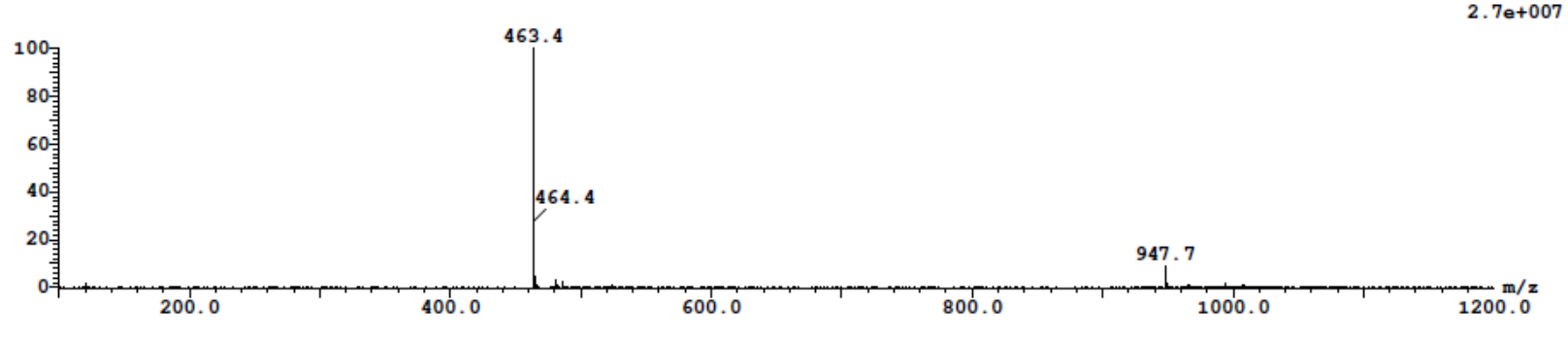

(Time: 4.44) Combine (532:535)

2: MS ES-

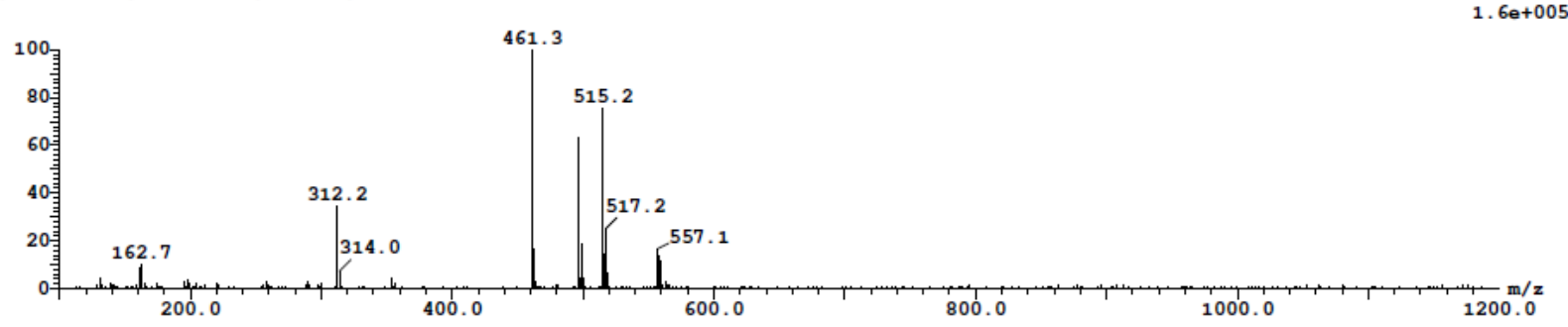


$\underline{400 \mathrm{MHz}{ }^{1} \mathrm{H} \text { NMR of } 68 \text { in DMSO }}$

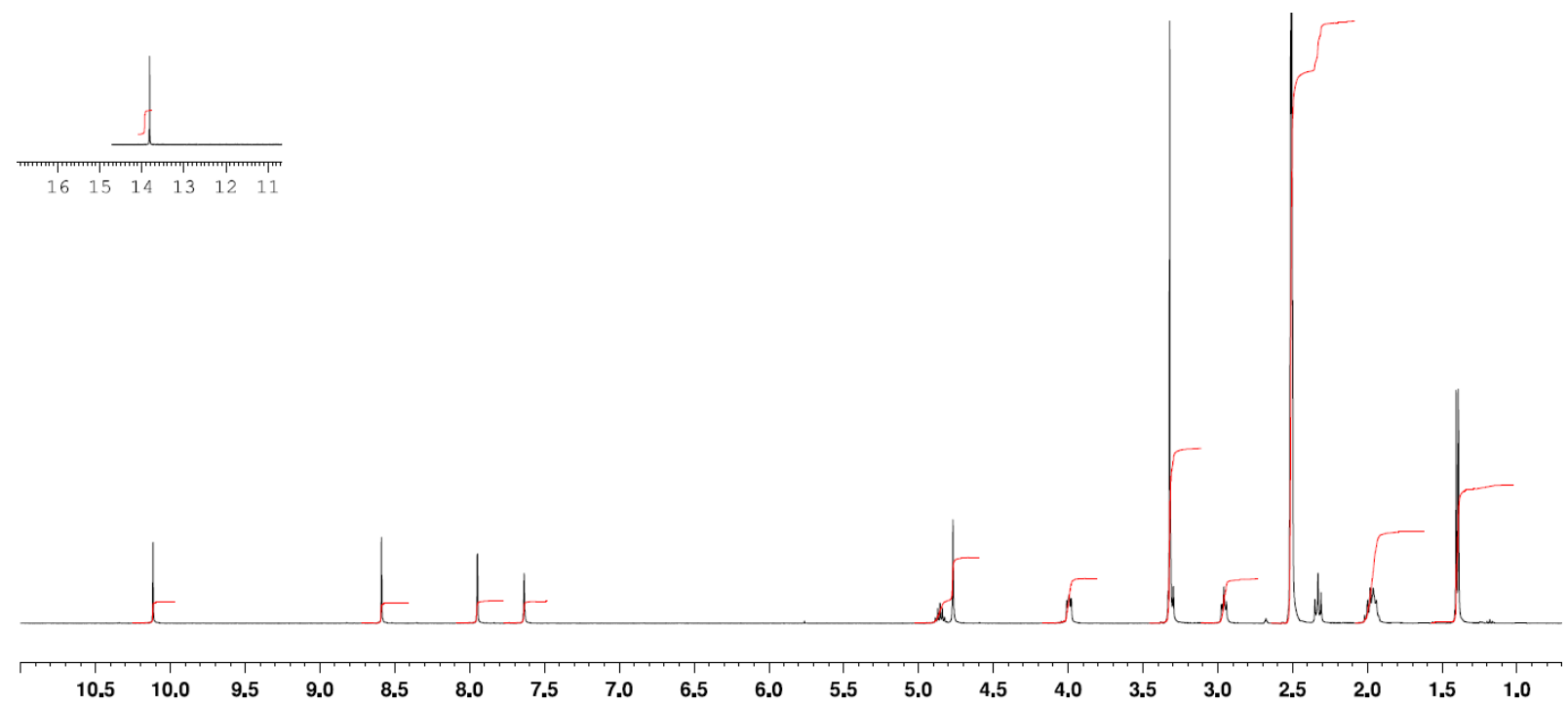

$\underline{101 \mathrm{MHz}{ }^{13} \mathrm{C} \text { NMR of } 68 \text { in DMSO }}$

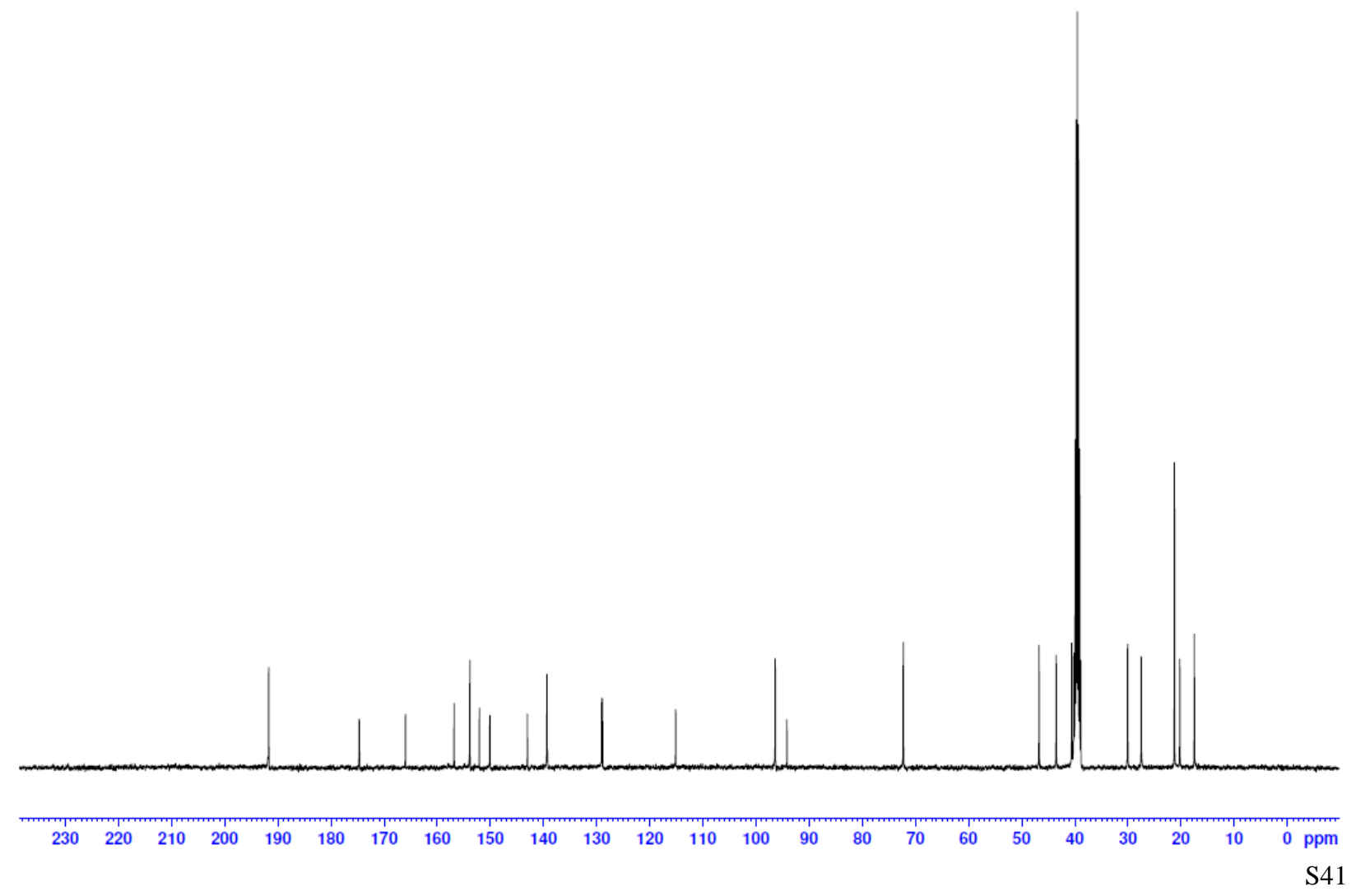


$\underline{600 \mathrm{MHz}{ }^{1} \mathrm{H},{ }^{13} \mathrm{C} \text { HSQC NMR of } 68 \text { in DMSO }}$
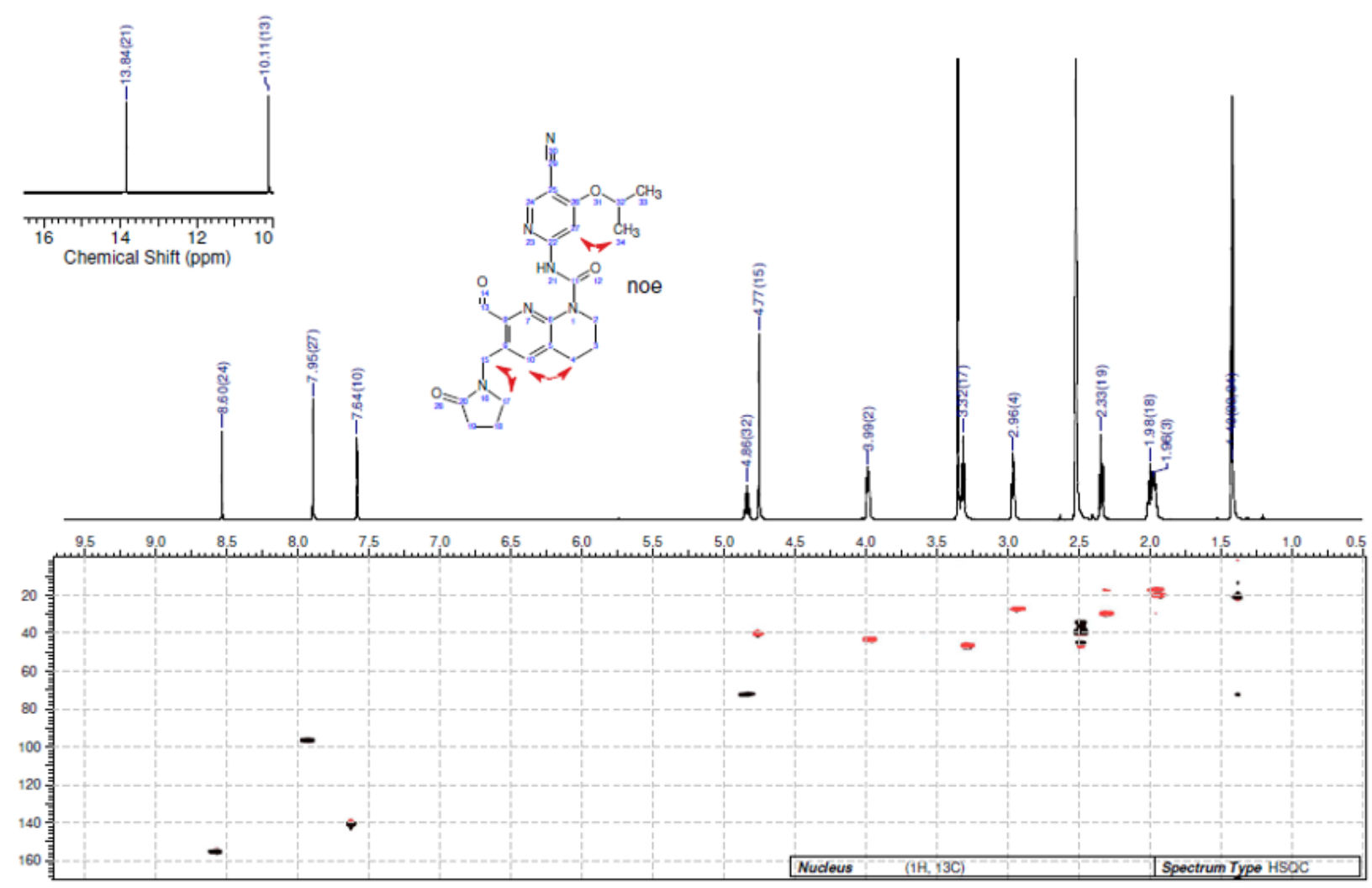
Scheme 4 Synthetic route to compound $\mathbf{8 4}$, using CDT for the urea formation

ethyl 2-((2-((tert-butoxycarbonyl)amino)ethyl)(methyl)amino)acetate

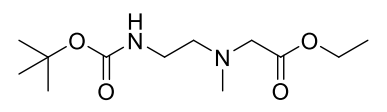

Ethyl bromoacetate $(1.27 \mathrm{~mL}, 11.48 \mathrm{mmol})$ was added to a mixture of tert.butyl (2-(methylamino)ethyl)carbamate $(2.0 \mathrm{~g}, 11.48 \mathrm{mmol})$, triethylamine $(4.81 \mathrm{~mL})$ and $\mathrm{THF}(24 \mathrm{~mL})$ at $0{ }^{\circ} \mathrm{C}$. After stirring $24 \mathrm{~h}$ at room temperature the reaction mixture was partitioned between saturated aqueous $\mathrm{NaHCO}_{3}$ and $\mathrm{DCM}$, extracted 2x with DCM, the organic layers dried over $\mathrm{Na}_{2} \mathrm{SO}_{4}$ and evaporated to give the title compound as a clear pale-yellow oil. ${ }^{1} \mathrm{H} \mathrm{NMR}(400 \mathrm{MHz}$, $\left.\mathrm{CDCl}_{3}\right) \delta 5.20(\mathrm{~s}, \mathrm{br}, 1 \mathrm{H}, \mathrm{NH}), 4.18\left(\mathrm{q}, J=7.1 \mathrm{~Hz}, 2 \mathrm{H}, \mathrm{OCH}_{2} \mathrm{CH}_{3}\right), 3.24\left(\mathrm{~s}, 2 \mathrm{H}, \mathrm{CH}_{2} \mathrm{CO}_{2} \mathrm{Et}\right), 3.22-3.16(\mathrm{~m}, 2 \mathrm{H}$, $\left.\mathrm{HNCH}_{2}\right), 2.65-2.61\left(\mathrm{~m}, 2 \mathrm{H}, \mathrm{MeNCH}_{2}\right), 2.38\left(\mathrm{~s}, 3 \mathrm{H}, \mathrm{NCH}_{3}\right), 1.42\left(\mathrm{~s}, 9 \mathrm{H}, \mathrm{C}\left(\mathrm{CH}_{3}\right)_{3}\right), 1.24(\mathrm{t}, J=7.1 \mathrm{~Hz}, 3 \mathrm{H}$, $\left.\mathrm{OCH}_{2} \mathrm{CH}_{3}\right)$.

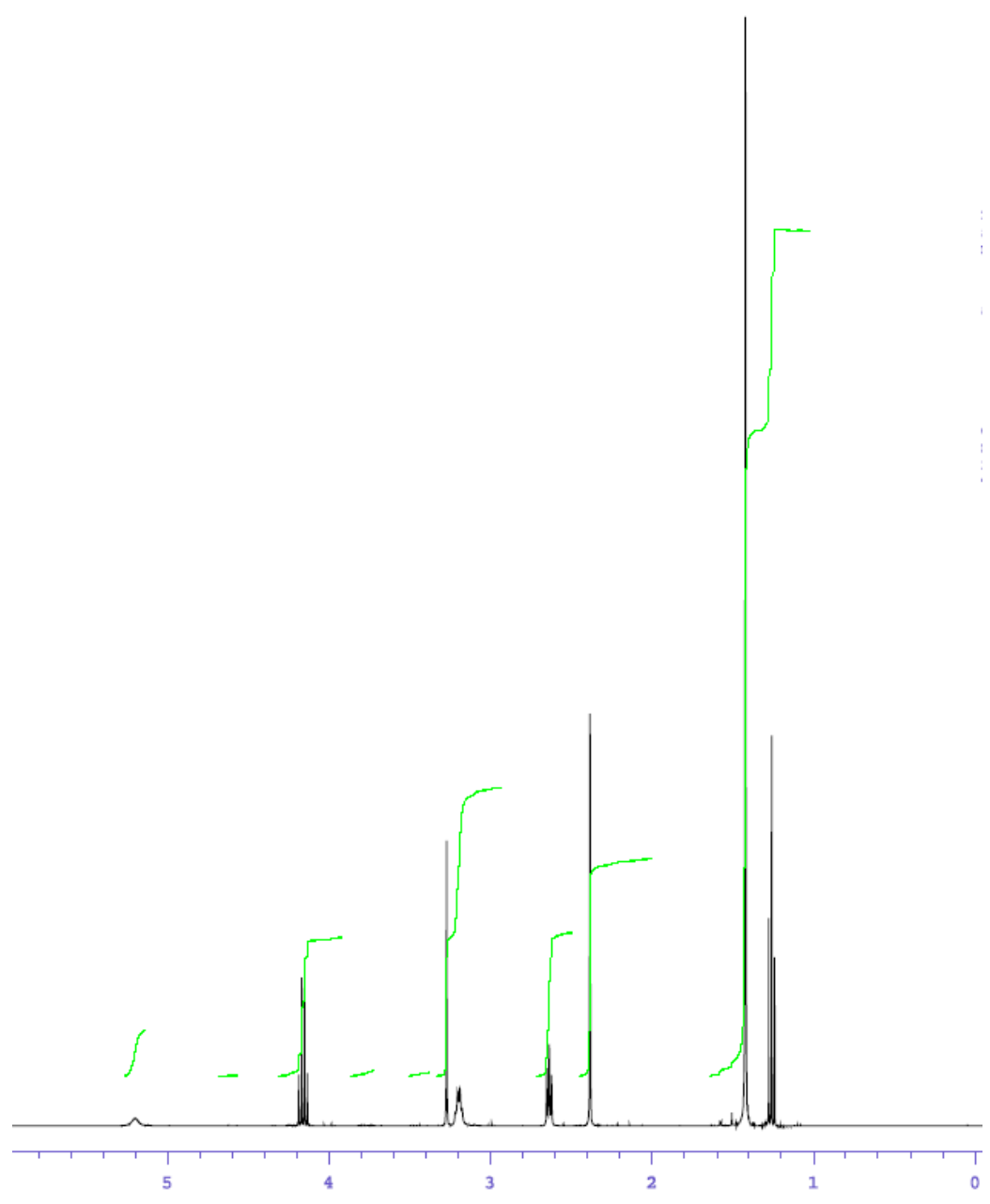


ethyl 2-((2-aminoethyl)(methyl)amino)acetate dihydrochloride $\mathbf{1 0 8}$

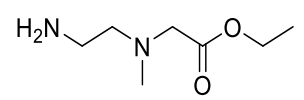

Concentrated hydrochloric acid (10 $\mathrm{mL})$ was added to a solution of ethyl 2 - $((2-)(($ tertbutoxycarbonyl)amino)ethyl)(methyl)amino)acetate $(3.05 \mathrm{~g}, 11.13 \mathrm{mmol})$ in THF (20 mL) and EtOH (100 mL) at room temperature. After stirring $1 \mathrm{~h}$ at room temperature the reaction mixture was evaporated, ethanol (20 mL) added, evaporated, further ethanol $(50 \mathrm{~mL})$ added and then stirred at $60^{\circ} \mathrm{C}$ for $70 \mathrm{~min}$. The cooled reaction mixture was then evaporated to give the title compound as a pale-yellow glass. ${ }^{1} \mathrm{H}$ NMR $\left(400 \mathrm{MHz}, \mathrm{DMSO}-d_{6}\right) \delta 8.58\left(\mathrm{~s}, \mathrm{br}, 3 \mathrm{H},{ }^{+} \mathrm{NH} 3\right)$, $4.24\left(\mathrm{~s}, 2 \mathrm{H}, \mathrm{MeNCH}_{2}\right), 4.19$ (q, $\left.J=7.2 \mathrm{~Hz}, 2 \mathrm{H}, \mathrm{OCH}_{2} \mathrm{CH}_{3}\right), 3.44$ (s, br, $2 \mathrm{H}, \mathrm{CH}_{2} \mathrm{CO}_{2} \mathrm{Et}$ ), $3.21\left(\mathrm{~s}, \mathrm{br}, 2 \mathrm{H}, \mathrm{H}_{3} \mathrm{NCH}\right.$ ), $2.88\left(\mathrm{~s}, 3 \mathrm{H}, \mathrm{NCH}_{3}\right), 1.21\left(\mathrm{t}, J=7.2 \mathrm{~Hz}, 3 \mathrm{H}, \mathrm{OCH}_{2} \mathrm{CH}_{3}\right)$.

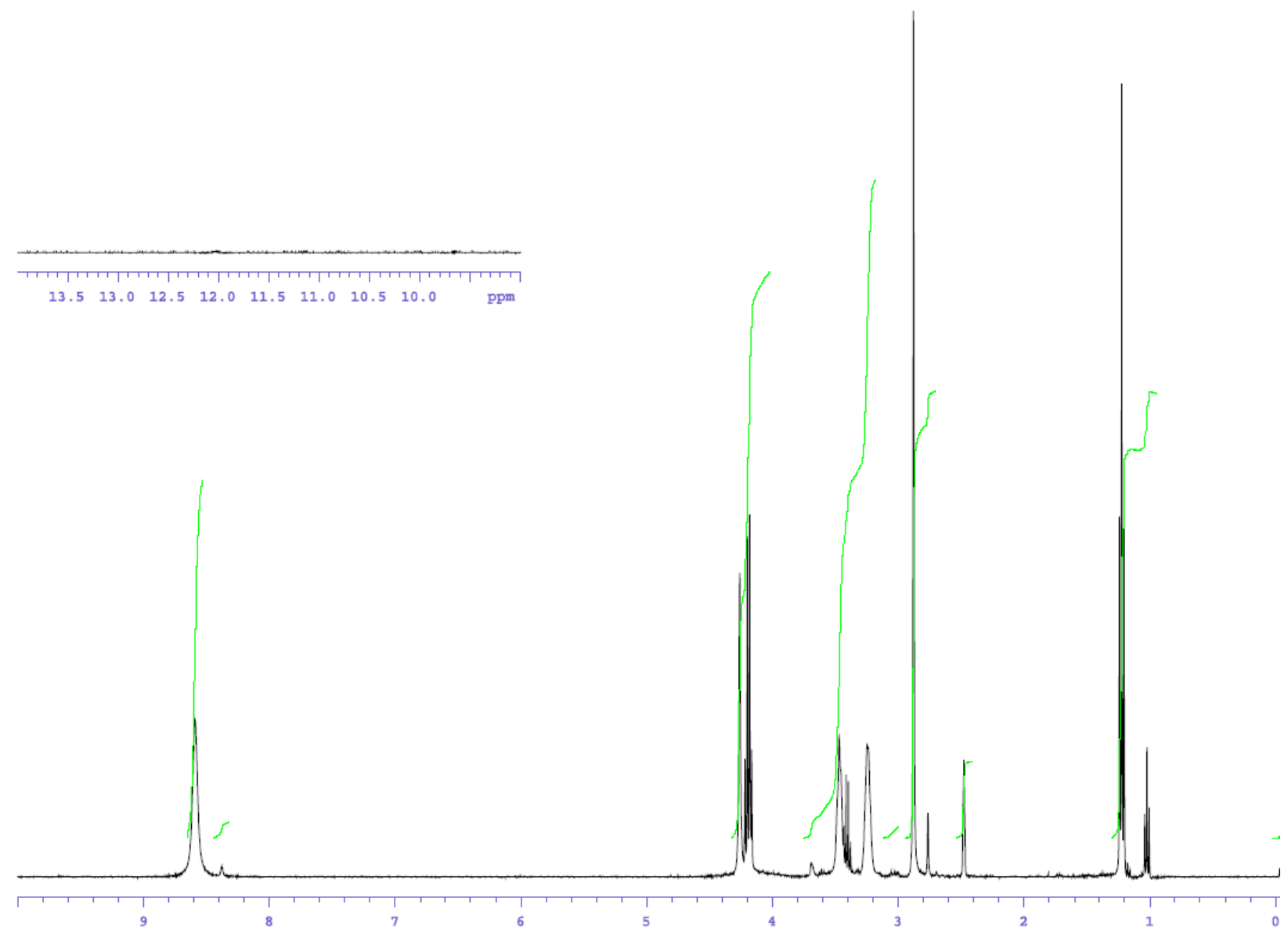




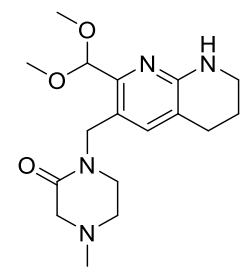

Sodium triacetoxyborohydride $(3.10 \mathrm{~g}, 14.61 \mathrm{mmol})$ was added over $5 \mathrm{~min}$ to a mixture of 2-(dimethoxymethyl)5,6,7,8-tetrahydro-1,8-naphthyridine-3-carbaldehyde $\quad(\mathbf{1 0 1}, \quad 2.30 \quad \mathrm{~g}, \quad 9.74 \quad \mathrm{mmol}), \quad$ ethyl 2-((2aminoethyl)(methyl)amino)acetate dihydrochloride (108, $2.6 \mathrm{~g}, 14.61 \mathrm{mmol})$ and triethylamine $(6.75 \mathrm{~mL}, 48.7 \mathrm{mmol})$ in 1,2-dichloroethane $(20 \mathrm{~mL})$ at room temperature. The reaction mixture was stirred for $21 \mathrm{~h}$ at room temperature and additional sodium triacetoxyborohydride $(2.6 \mathrm{~g}, 9.74 \mathrm{mmol})$ was added. After a further $4 \mathrm{~h}$ stirring at room temperature, again additional sodium triacetoxyborohydride $(1.3 \mathrm{~g}, 4.87 \mathrm{mmol})$ was added and the reaction maintained at $4{ }^{\circ} \mathrm{C}$ for 2.5 days. The reaction mixture was then warmed to room temperature, saturated aqueous $\mathrm{NaHCO}_{3}$ solution added, the mixture extracted $3 \mathrm{x}$ with DCM, the combined organic layers dried over $\mathrm{Na}_{2} \mathrm{SO}_{4}$ and evaporated. The residue was applied to a $120 \mathrm{~g}$ RediSep silica column as a DCM solution and purified by normal phase chromatography, eluting with a gradient from DCM to $10 \% \mathrm{MeOH}$ in DCM. Product containing fractions were combined and evaporated to give the title compound as an orange foam. LC-MS (method A) tR $0.33 \mathrm{~min}, \mathrm{~m} / z .303 .2$ (45\%, M-OMe), $335.3(100 \%, \mathrm{M}+\mathrm{H}) .{ }^{1} \mathrm{H}$ NMR (400 MHz, DMSO-d $\left.{ }_{1}\right) \delta 6.90$ (s, 1H, Ar H), 6.47 (s, br, $\left.1 \mathrm{H}, \mathrm{NH}\right), 4.99$ $\left(\mathrm{s}, 1 \mathrm{H}, \mathrm{CH}(\mathrm{OMe})_{2}\right), 4.51\left(\mathrm{~s}, 2 \mathrm{H}, \mathrm{C}(\mathrm{O}) \mathrm{CH}_{2}\right), 3.28\left(\mathrm{~s}, 6 \mathrm{H}, \mathrm{CH}\left(\mathrm{OCH}_{3}\right)_{2}\right), 3.05\left(\mathrm{t}, 2 \mathrm{H}, \mathrm{J}=6.5 \mathrm{~Hz}, \mathrm{NCH}_{2} \mathrm{CH}_{2} \mathrm{NMe}\right), 3.08$ - $3.03\left(\mathrm{~m}, 2 \mathrm{H}, \mathrm{CH}_{2} \mathrm{CH}_{2} \mathrm{CH}_{2} \mathrm{~N}\right), 2.96\left(\mathrm{~s}, 2 \mathrm{H}, \mathrm{ArCH}_{2}\right), 2.59\left(\mathrm{t}, 2 \mathrm{H}, J=6.7 \mathrm{~Hz}, \mathrm{ArCH}_{2} \mathrm{CH}_{2}\right), 2.51-2.45(\mathrm{~m}, 2 \mathrm{H}$, $\left.\mathrm{ArCH}_{2} \mathrm{CH}_{2}\right), 2.16$ (s, 3H, $\left.\mathrm{NCH}_{3}\right), 1.76-1.69$ (m, 2H, $\left.\mathrm{NHCH}_{2} \mathrm{CH}_{2}\right)$.

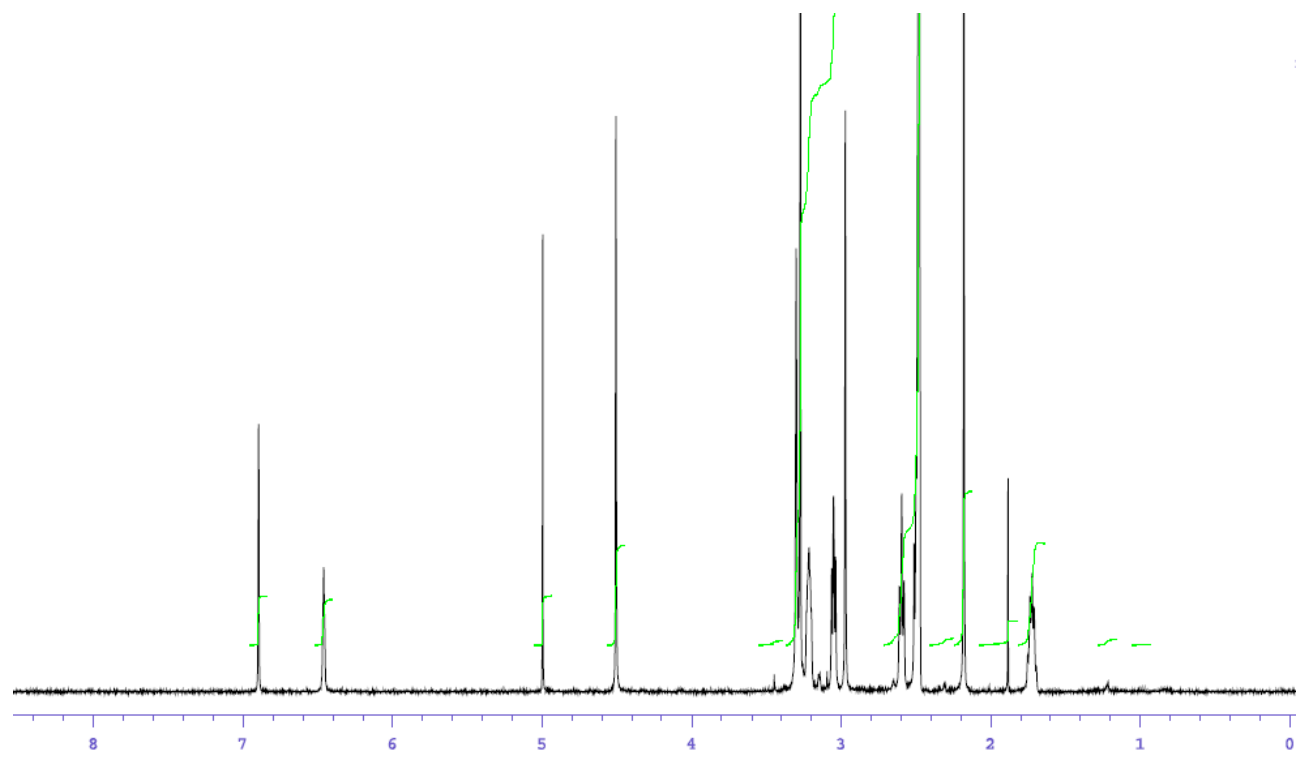


N-(5-cyano-4-((2-methoxyethyl)amino)pyridin-2-yl)-7-(dimethoxymethyl)-6-((4-methyl-2-oxopiperazin-1yl)methyl)-3,4-dihydro-1,8-naphthyridine-1 $(2 H)$-carboxamide $\mathbf{1 1 0}$

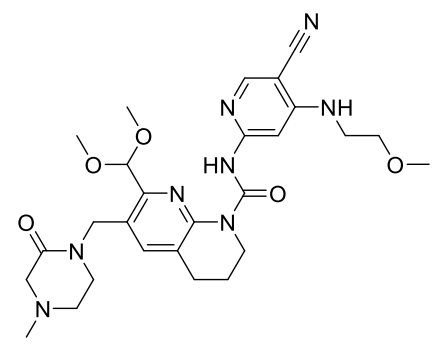

A solution of 6-amino-4-((2-methoxyethyl)amino)nicotinonitrile (96, $481 \mathrm{mg}, 2.50 \mathrm{mmol})$ in anhydrous DMF (1.5 $\mathrm{mL})$ was added drop wise over 10 minutes to a mixture of di(1H-1,2,4-triazol-1-yl)methanone (410 mg, $2.50 \mathrm{mmol})$ and DMF $(1.5 \mathrm{~mL})$ cooled at $0{ }^{\circ} \mathrm{C}$. After stirring for 45 minutes at $0{ }^{\circ} \mathrm{C}$ the reaction mixture was allowed to warm to room temperature and after a further $90 \mathrm{~min}$ at room temperature a solution of 1 -((2-(dimethoxymethyl)-5,6,7,8tetrahydro-1,8-naphthyridin-3-yl)methyl)-4-methylpiperazin-2-one (109, $418 \mathrm{mg}, 1.00 \mathrm{mmol}) \mathrm{in} \mathrm{DMF}(2 \mathrm{~mL}) \mathrm{was}$ added. The reaction mixture was stirred for $18 \mathrm{~h}$ at room temperature, quenched by the addition of $\mathrm{MeOH}$ and evaporated. The residue was applied to a $80 \mathrm{~g}$ RediSep silica column as a DCM solution and purified by normal phase chromatography, eluting with a gradient from DCM to $2 \% \mathrm{MeOH}$ in DCM. Product containing fractions were combined and evaporated to give the title compound as an orange foam. LC-MS (method A) tR $0.74 \mathrm{~min}, \mathrm{~m} / z 553.4$ $(100 \%, \mathrm{M}+\mathrm{H}), 191.0(100 \%$, pyridyl-NH$), 551.4(25 \%, \mathrm{M}-\mathrm{H}), 597.4$ (45\%, M+HCO $\left.2^{-}\right) .{ }^{1} \mathrm{H}$ NMR (400 MHz, DMSOd6) $\delta 13.50(\mathrm{~s}, 1 \mathrm{H}, \mathrm{NC}(\mathrm{O}) \mathrm{NH}), 8.27(\mathrm{~s}, 1 \mathrm{H}, \mathrm{Ar} \mathrm{H}), 7.52(\mathrm{~s}, 1 \mathrm{H}, \operatorname{Ar} \mathrm{H}), 7.39(\mathrm{~s}, 1 \mathrm{H}, \operatorname{Ar} \mathrm{H}), 6.93(\mathrm{t}, J=5.3 \mathrm{~Hz}, 1 \mathrm{H}$, $\left.\mathrm{CH}_{2} \mathrm{NH}\right), 5.45\left(\mathrm{~s}, 1 \mathrm{H}, \mathrm{CH}(\mathrm{OMe})_{2}\right), 4.65\left(\mathrm{~s}, 2 \mathrm{H}, \mathrm{ArCH}_{2}\right), 3.94-3.89\left(\mathrm{~m}, 2 \mathrm{H}, \mathrm{NCH}_{2} \mathrm{CH}_{2} \mathrm{CH}_{2}\right), 3.54-3.50(\mathrm{~m}, 2 \mathrm{H}$, $\mathrm{CH}_{2} \mathrm{OMe}$ ), $3.40-3.35\left(\mathrm{~m}, 2 \mathrm{H}, \mathrm{NHCH}_{2}\right), 3.38$ (s, 6H, $\left.\mathrm{CH}\left(\mathrm{OCH}_{3}\right)_{2}\right), 3.29\left(\mathrm{~s}, 3 \mathrm{H}, \mathrm{CH}_{2} \mathrm{OCH}_{3}\right), 3.20-3.16(\mathrm{~m}, 2 \mathrm{H}$, $\mathrm{MeNCH}_{2} \mathrm{CH}_{2}$ ), 3.05 (s, 2H, $\mathrm{MeNCH}_{2} \mathrm{CO}$ ), $2.86-2.80$ (m, 2H, $\mathrm{ArCH}_{2} \mathrm{CH}_{2}$ ), $2.61-2.55$ (m, 2H, $\mathrm{MeNCH}_{2} \mathrm{CH}_{2}$ ), 2.22 (s, $\left.3 \mathrm{H}, \mathrm{NCH}_{3}\right), 1.94-1.88\left(\mathrm{~m}, 2 \mathrm{H}, \mathrm{NCH}_{2} \mathrm{CH}_{2} \mathrm{CH}_{2}\right)$. 


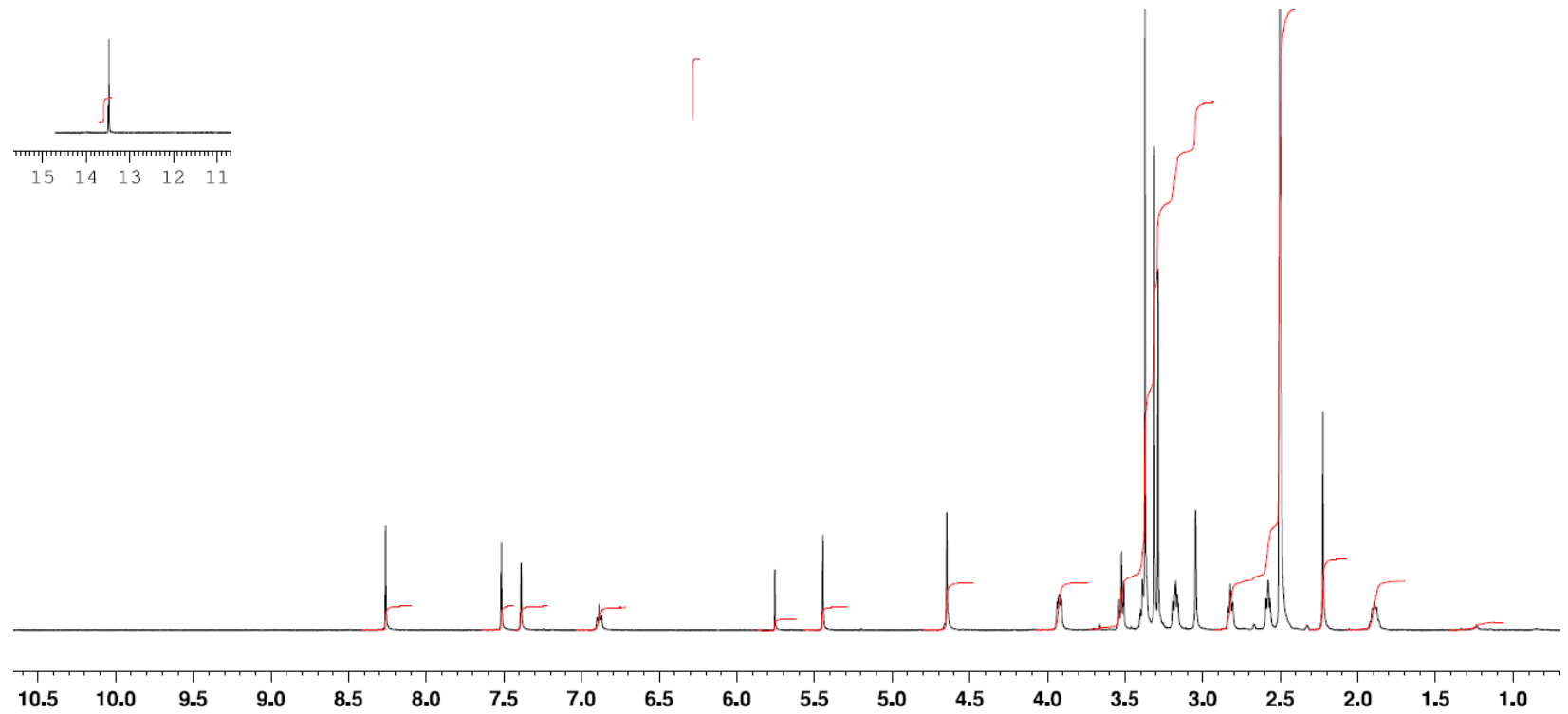


N-(5-cyano-4-((2-methoxyethyl)amino)pyridin-2-yl)-7-formyl-6-((4-methyl-2-oxopiperazin-1-yl)methyl)-3,4dihydro-1,8-naphthyridine-1 $(2 H)$-carboxamide 84

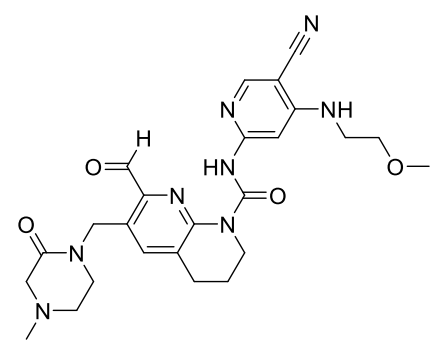

Concentrated hydrochloric acid $(0.40 \mathrm{~mL})$ was added to a solution of $N$-(5-cyano-4-((2-methoxyethyl)amino)pyridin2-yl)-7-(dimethoxymethyl)-6-((4-methyl-2-oxopiperazin-1-yl)methyl)-3,4-dihydro-1,8-naphthyridine-1(2H)carboxamide $(\mathbf{1 0 9}, 470 \mathrm{mg}, 0.808 \mathrm{mmol})$ in THF $(3 \mathrm{~mL})$ and water $(1 \mathrm{~mL})$ at room temperature. After stirring for $3 \mathrm{~h}$ at room temperature saturated aqueous $\mathrm{NaHCO}_{3}$ was added, the mixture extracted $3 \mathrm{x}$ with DCM, the organic layers dried over $\mathrm{Na}_{2} \mathrm{SO}_{4}$ and evaporated. The residue was sonicated with EtOAc $(6 \mathrm{~mL})$ and pentane $(6 \mathrm{~mL})$ and then filtered. The white solid obtained was then dissolved in DCM (6 mL), EtOAc added (3 mL), the solution warmed, sealed and allowed to stand at room temperature for $2 \mathrm{~h}$. Filtration and drying gave the title compound as a white solid. mp $224{ }^{\circ} \mathrm{C}$ (DSC). LC-MS (method A) tr $0.70 \mathrm{~min}, \mathrm{~m} / z, 507.3$ (100\%, M+H), 217.1 (100\%, pyridyl-NCO-H), 505.2 $(50 \%, \mathrm{M}-\mathrm{H}), 551.2\left(20 \%, \mathrm{M}+\mathrm{HCO}_{2}-\right) .{ }^{1} \mathrm{H}$ NMR $\left(600 \mathrm{MHz}, \mathrm{DCM}-d_{2}\right) \delta 13.61(\mathrm{~s}, 1 \mathrm{H}, \mathrm{NC}(\mathrm{O}) \mathrm{NH}), 10.17(\mathrm{~s}, 1 \mathrm{H}$, $\mathrm{C}(\mathrm{O}) \mathrm{H}), 8.14(\mathrm{~s}, 1 \mathrm{H}, \mathrm{Ar} \mathrm{H}), 7.55(\mathrm{~s}, 1 \mathrm{H}, \mathrm{Ar} \mathrm{H}), 7.52$ (s, 1H, Ar H), $5.30(\mathrm{t}, 1 \mathrm{H}, J=5.2 \mathrm{~Hz}, \mathrm{NHCH}), 5.00(\mathrm{~s}, 2 \mathrm{H}$, $\left.\mathrm{ArCH}_{2} \mathrm{~N}\right), 4.04-4.00\left(\mathrm{~m}, 2 \mathrm{H}, \mathrm{NCH}_{2} \mathrm{CH}_{2} \mathrm{CH}_{2}\right), 3.62\left(\mathrm{t}, 2 \mathrm{H}, J=5.2 \mathrm{~Hz}, \mathrm{CH}_{2} \mathrm{OMe}\right), 3.45\left(\mathrm{q}, 2 \mathrm{H}, J=5.2 \mathrm{~Hz}, \mathrm{NHCH}_{2}\right)$, $3.39\left(\mathrm{~s}, 3 \mathrm{H}, \mathrm{OCH}_{3}\right), 3.29\left(\mathrm{t}, 2 \mathrm{H}, J=5.4 \mathrm{~Hz}, \mathrm{NCH}_{2} \mathrm{CH}_{2} \mathrm{NMe}\right), 3.13\left(\mathrm{~s}, 2 \mathrm{H}, \mathrm{C}(\mathrm{O}) \mathrm{CH}_{2} \mathrm{NMe}\right), 2.91(\mathrm{t}, 2 \mathrm{H}, J=6.3 \mathrm{~Hz}$, $\left.\mathrm{ArCH}_{2} \mathrm{CH}_{2}\right), 2.62\left(\mathrm{t}, 2 \mathrm{H}, J=5.5 \mathrm{~Hz}, \mathrm{NCH}_{2} \mathrm{CH}_{2} \mathrm{NMe}\right), 2.30\left(\mathrm{~s}, 3 \mathrm{H}, \mathrm{NCH}_{3}\right), 2.02-1.98\left(\mathrm{~m}, 2 \mathrm{H}, \mathrm{ArCH}_{2} \mathrm{CH}_{2}\right) .{ }^{13} \mathrm{C} \mathrm{NMR}$ $\left(151 \mathrm{MHz}, \mathrm{DCM}-d_{2}\right) \delta 193.85,167.90,156.48,156.13,153.19,153.05,151.34,144.33,139.71,129.12,128.84$, 116.97, 93.30, 89.97, 70.43, 59.74, 59.24, 52.24, 47.63, 45.39, 44.61, 44.22, 42.86, 28.99, 21.30. IR (KBr disc) (̃max $\left(\mathrm{cm}^{-1}\right): 3351,3200,3012,2945,2879,2838,2822,2797,2723,2216,1713,1680,1646,1604,1526,1496,1475$, 1447, 1428, 1123. Raman $\tilde{V}_{\max }\left(\mathrm{cm}^{-1}\right):$ 3351, 3014, 2953, 2916, 2725, 2215, 1716, 1680, 1647, $1603,1570,1432$. HRMS-ESIMS $[\mathrm{M}+\mathrm{H}]^{+}$calcd for $\mathrm{C}_{25} \mathrm{H}_{30} \mathrm{~N}_{8} \mathrm{O}_{4}, 506.23900$, found 507.24628 (<0.1 ppm). UV (methanol) $\lambda$ max, nm (Є): 254 (39869), 273 (38346), 302 (16300), 290 (17273), 320 (6078). 


\section{$\underline{X-R a y ~ p o w d e r ~ d i f f r a c t i o n ~ p a t t e r n ~ f o r ~} \mathbf{8 4}$}

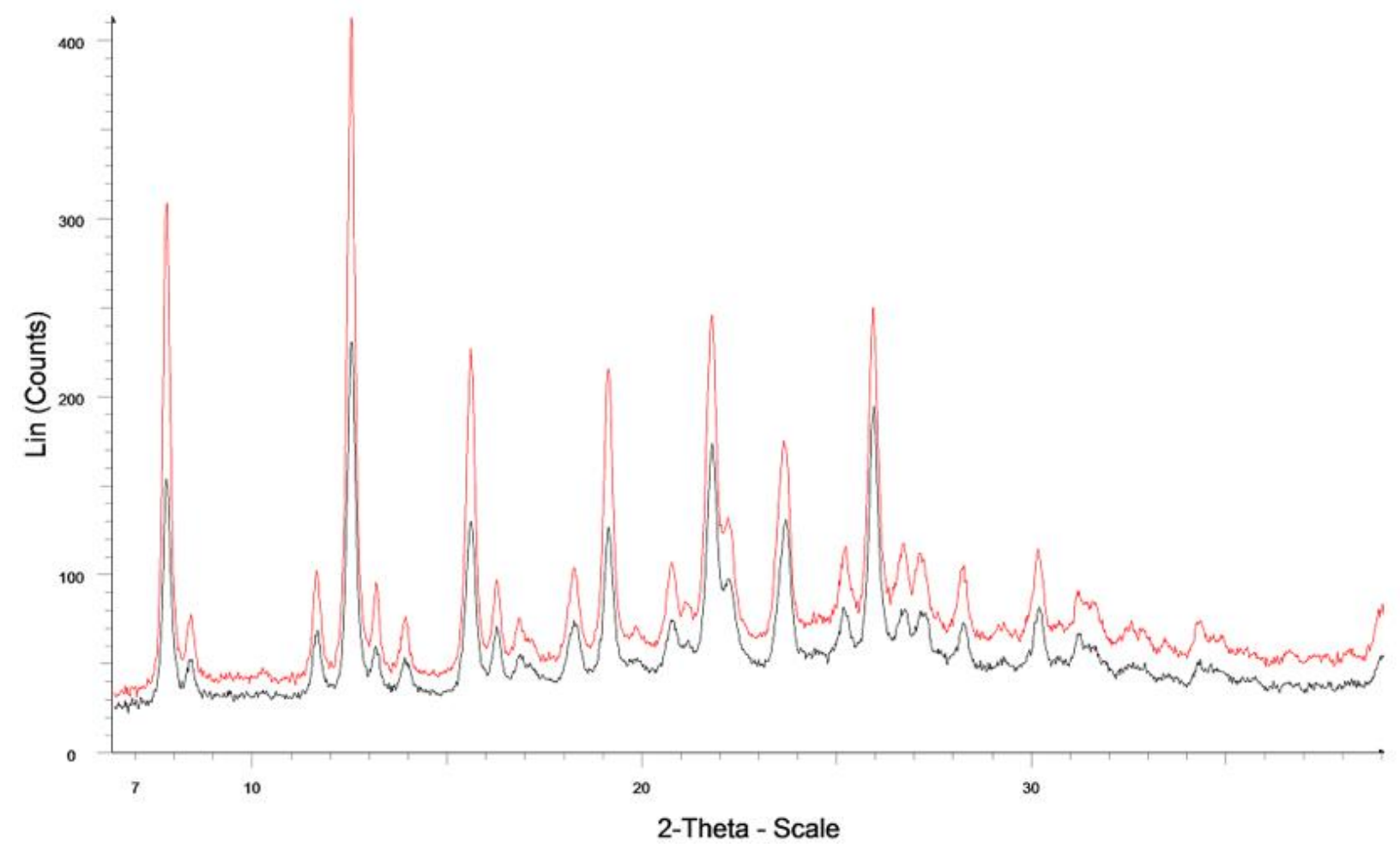

Black trace following isolation. Red trace following dynamic vapor sorption cycles with water. 


\section{LC/MS (Method A) 84}

UV Detector: TIC $1.845 e+2$
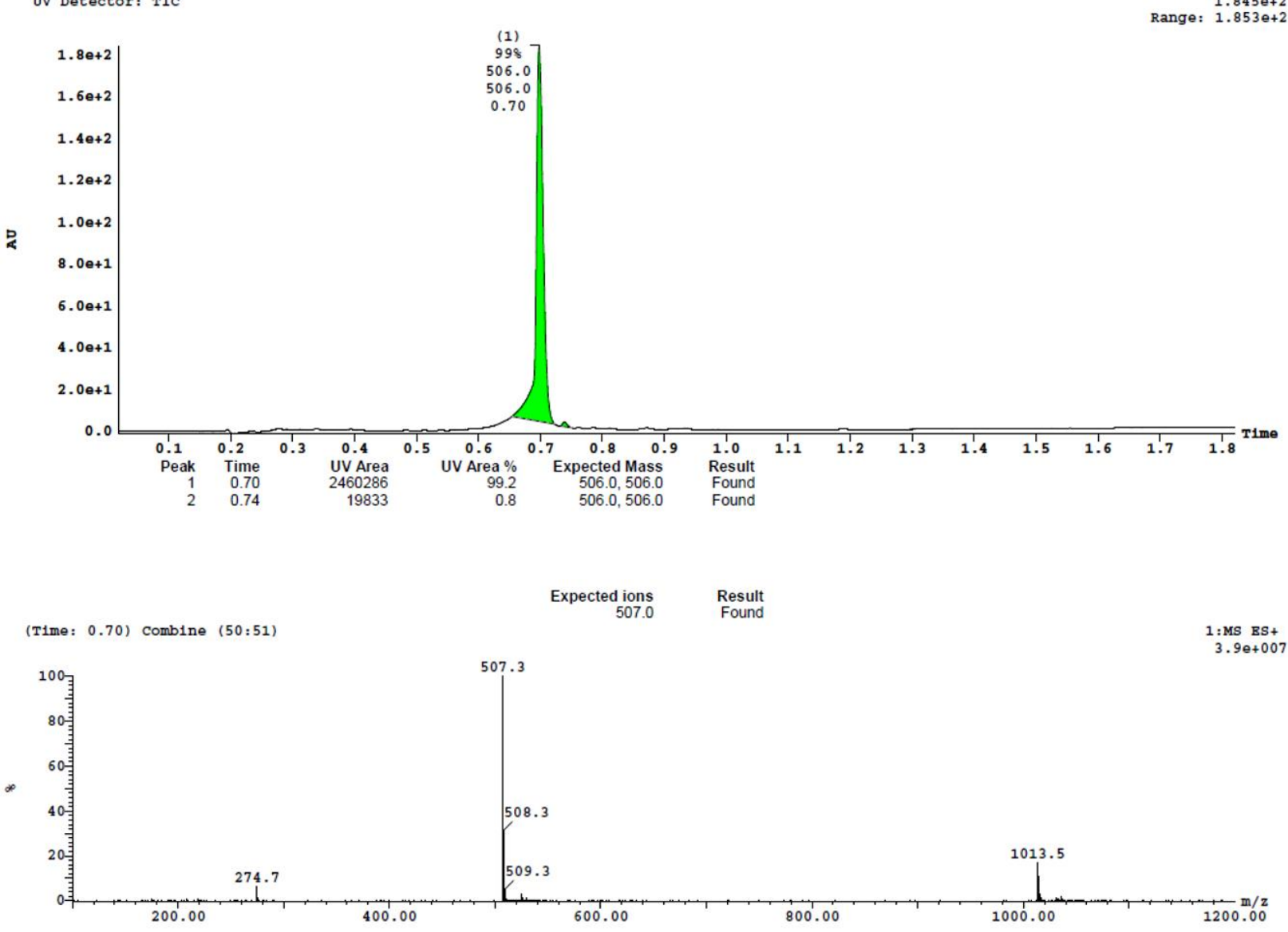

(T1me: 0.70$)$ comblne $(49: 50)$

2 : MS ES-

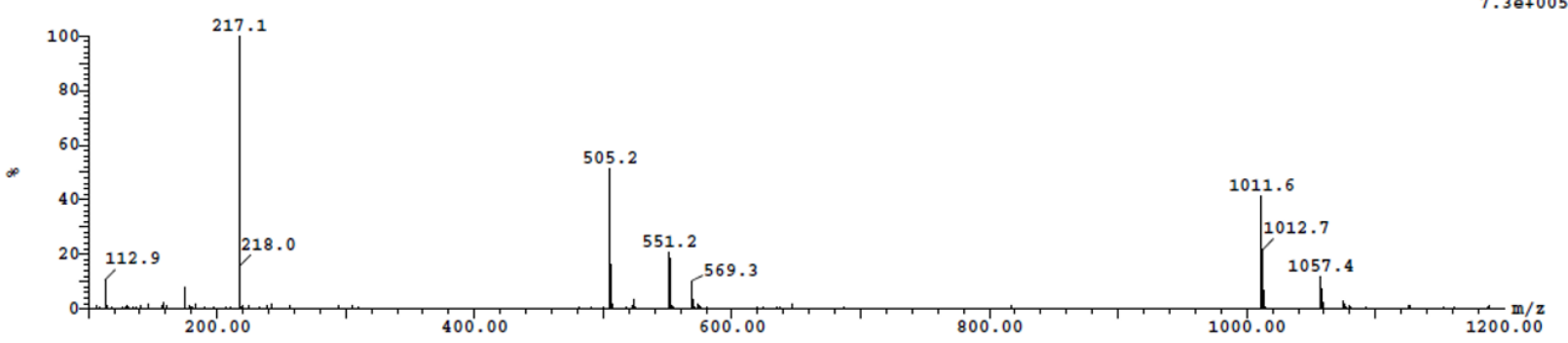




\section{LC/MS (Method C) 84}

UV Detector: TAC: Wavelength Range: (210 - 450)

9. $998 \mathrm{e}+1$

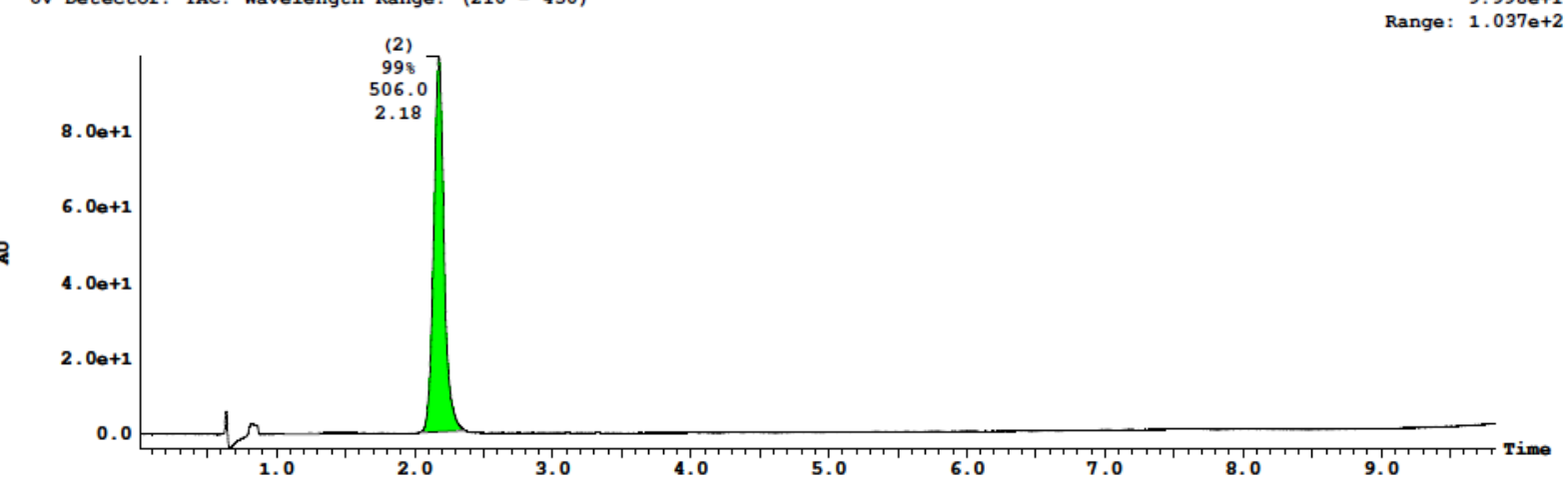

(Time: 2.18) Center (Cen, 4, 80.00, Ar); Combine (482:487)

1: MS ES+

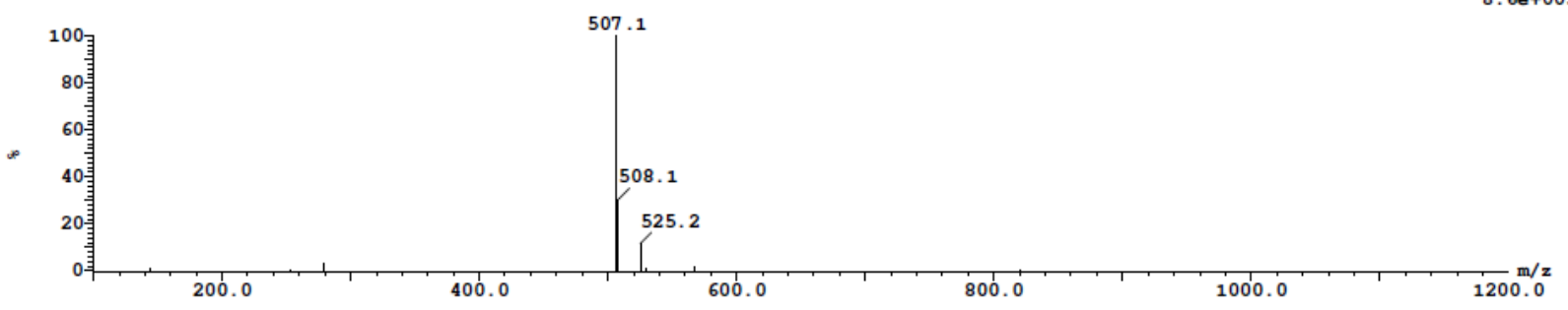


${ }^{1} \mathrm{H}$ NMR spectrum 84 in dichloromethane- $d_{1}$

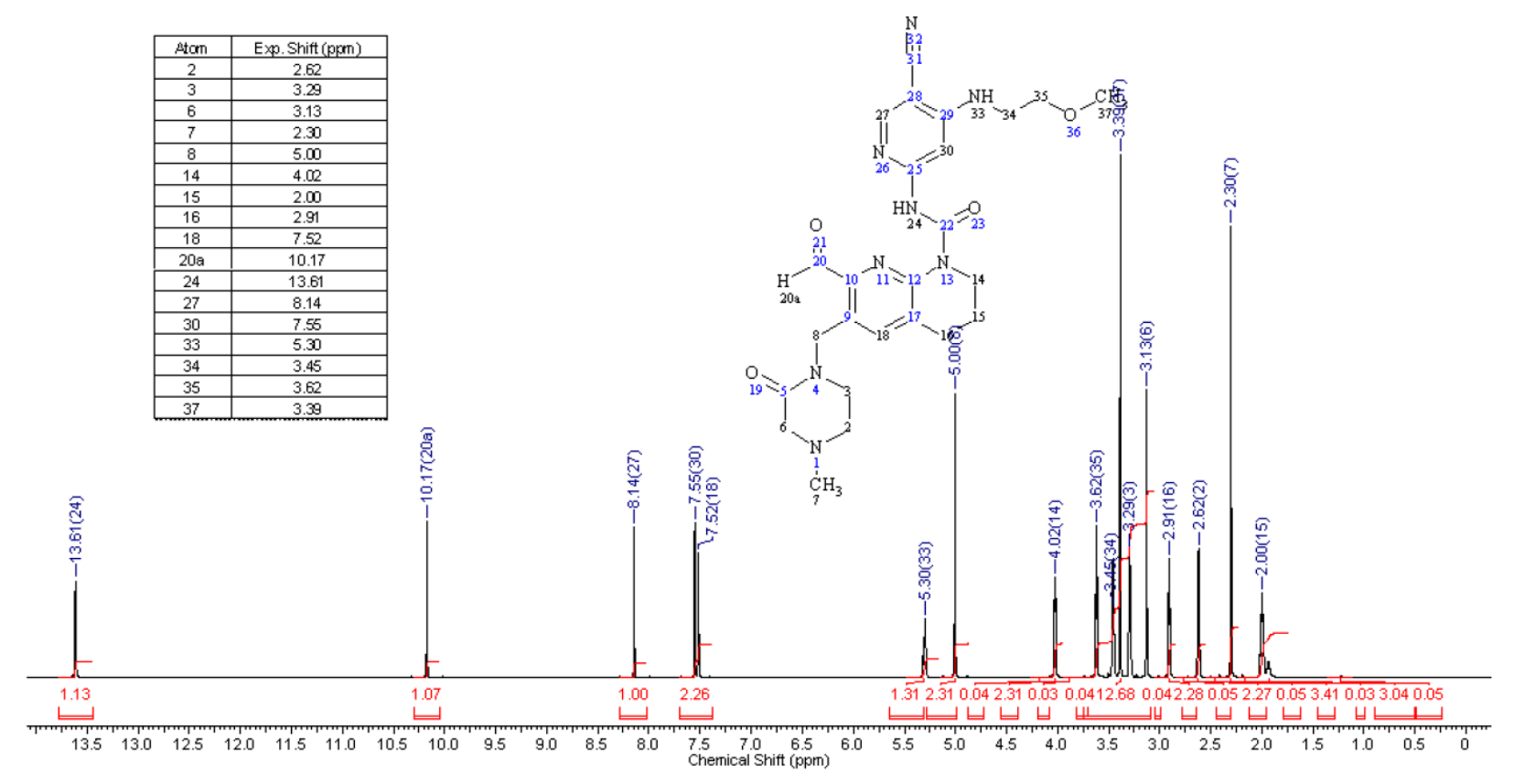

${ }^{13} \mathrm{C}$ NMR spectrum 84 in dichloromethane- $d_{1}$

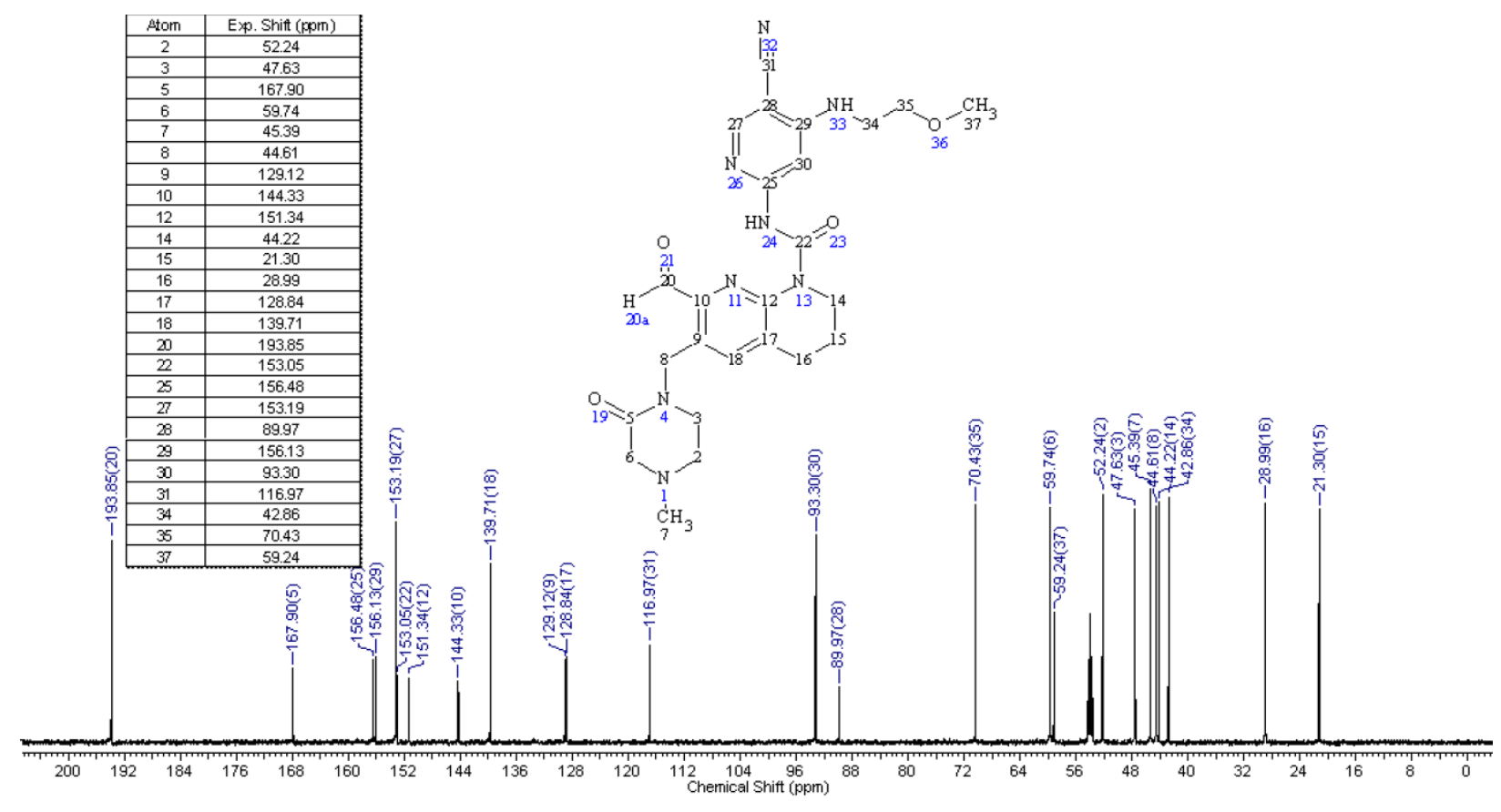




\section{Key COSY, ROESY and HMBC correlations for $\mathbf{8 4}$}

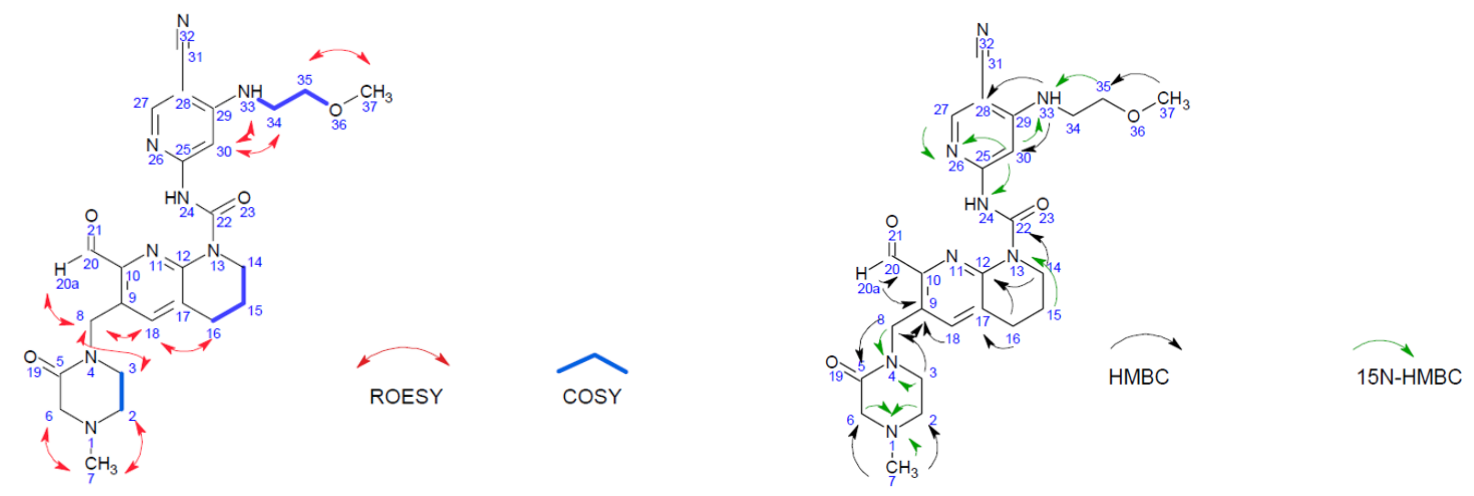

IR spectrum 84

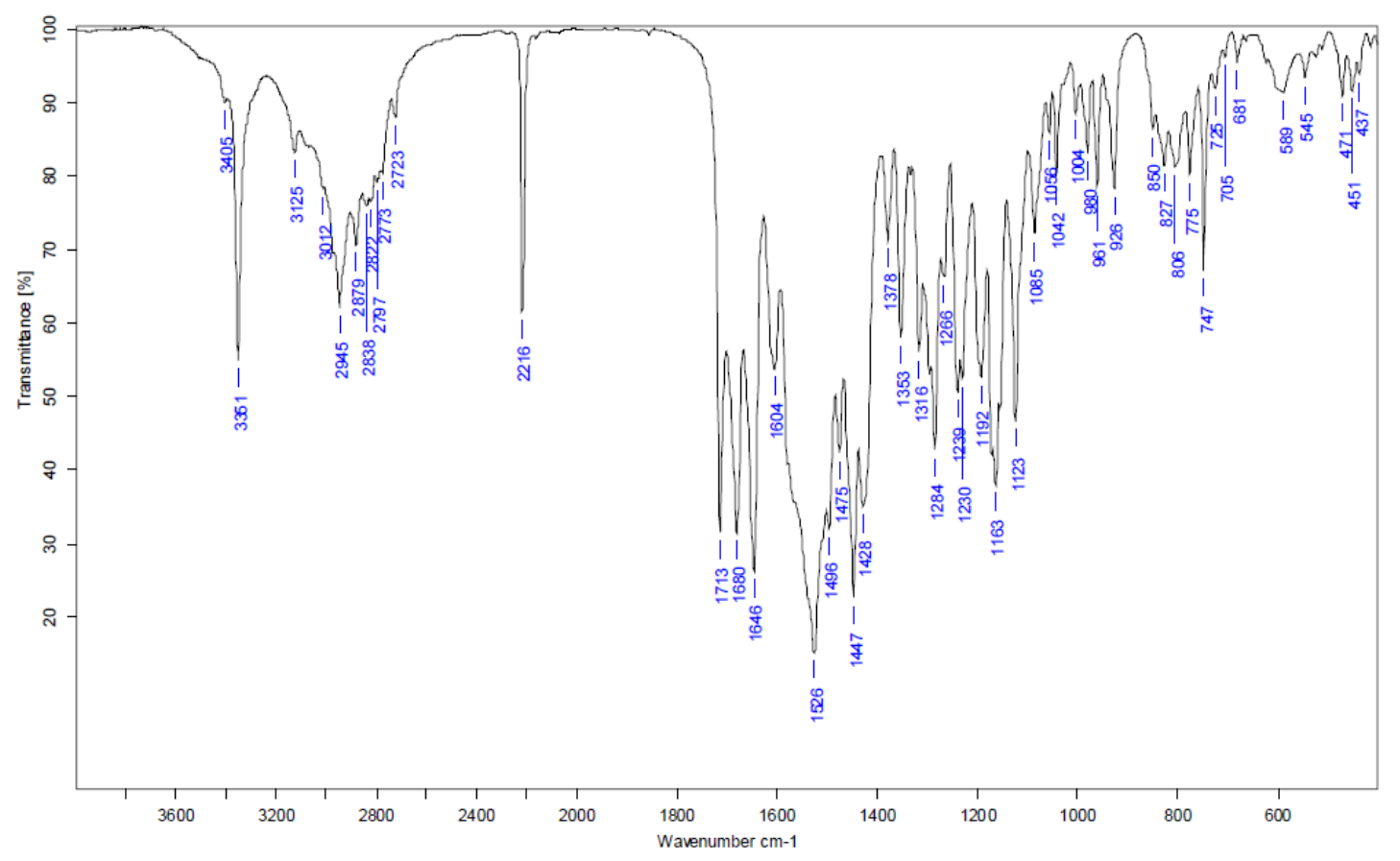




\section{Raman spectrum 84}

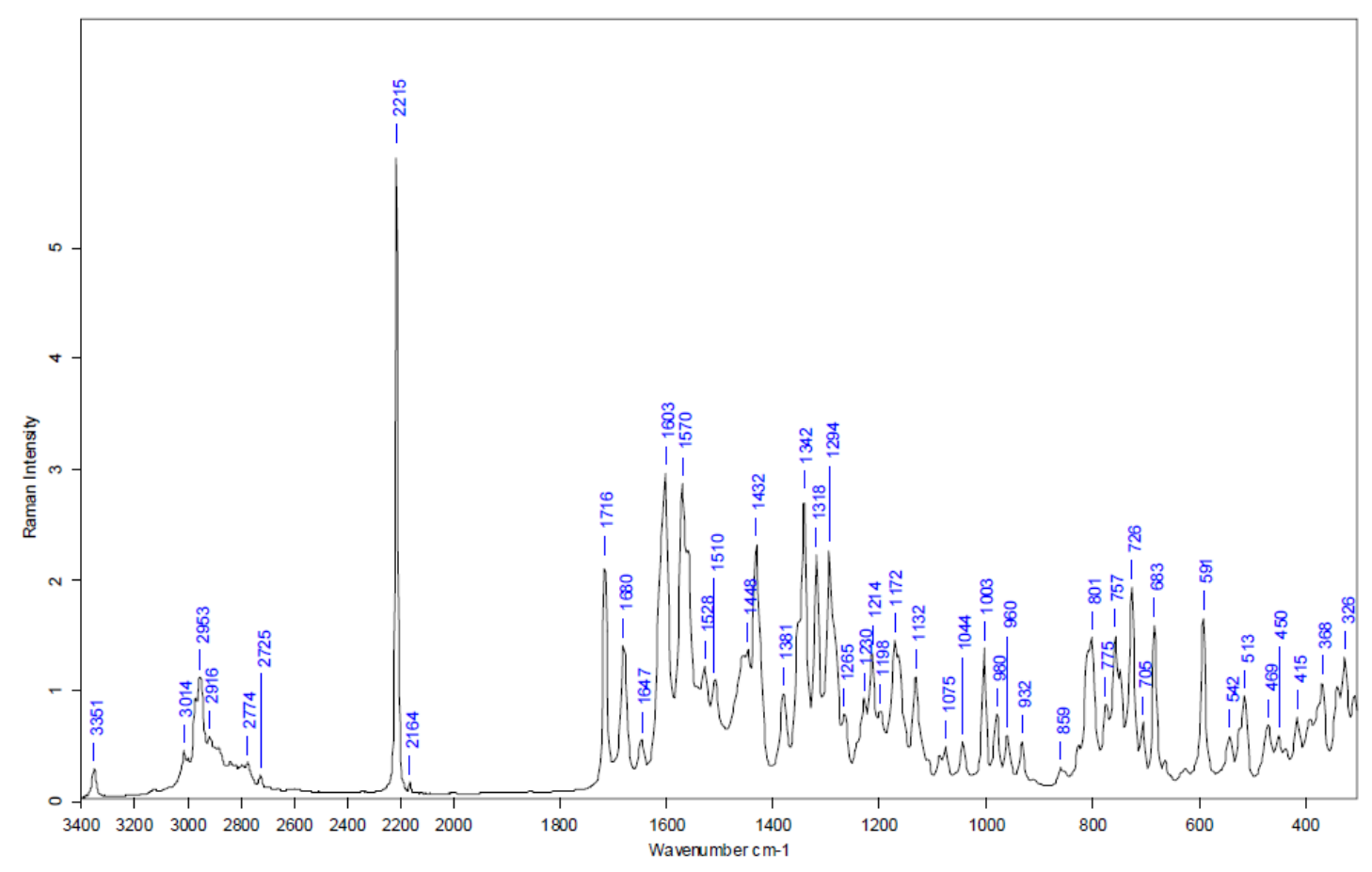

\section{$\underline{\text { UV-visible spectrum } 84}$}

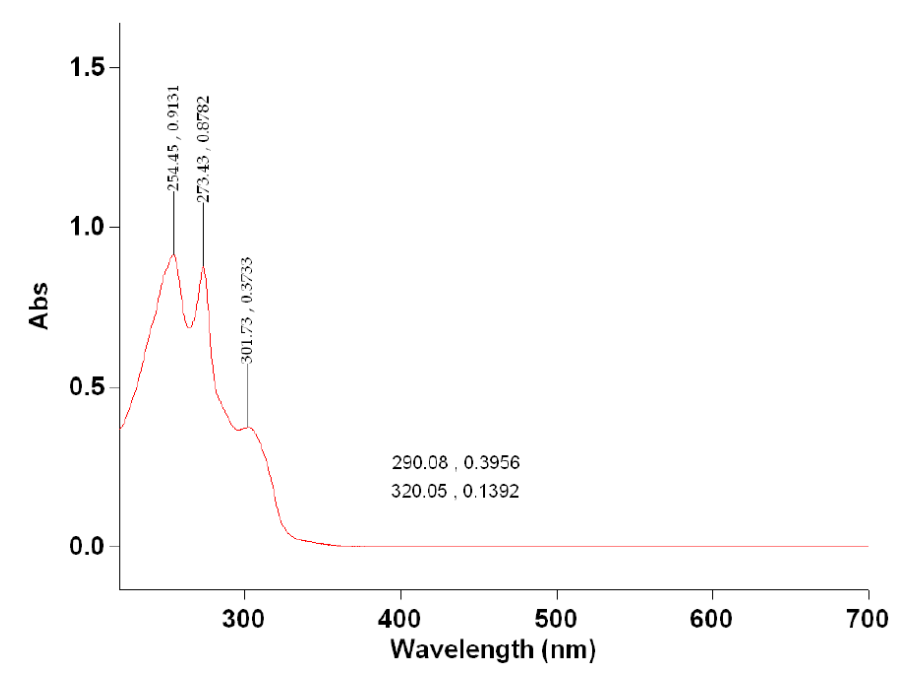


3-(5-cyano-4-(2-methoxyethoxy)pyridin-2-yl)-1-(2-cyanopyrimidin-4-yl)-1-methylurea 15

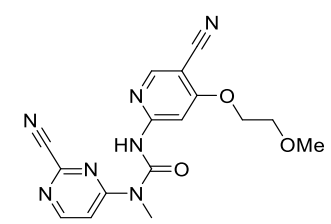

A solution of LiHMDS in THF (1 M, $1.01 \mathrm{~mL}, 1.01 \mathrm{mmol})$ was added dropwise to a solution of 4(methylamino)pyrimidine-2-carbonitrile $(68.0 \mathrm{mg}, 0.507 \mathrm{mmol}$ ) and phenyl (5-cyano-4-(2-methoxyethoxy)pyridin-2yl)carbamate (prepared in an analogous manner to that described above, $238 \mathrm{mg}, 0.760 \mathrm{mmol}$ ) in THF (5 mL) cooled with a dry ice/acetone bath. The RM was stirred for $30 \mathrm{~min}$ at $-78{ }^{\circ} \mathrm{C}$, warmed to RT and then quenched with aqueous $\mathrm{NH}_{4} \mathrm{Cl}$ solution. The mixture was extracted $1 \mathrm{x}$ with EtOAc and $1 \mathrm{x}$ with DCM and the combined organic layers evaporated. The residue was purified by normal phase chromatogaphy using a $24 \mathrm{~g}$ silica column, eluting a gradient from DCM to DCM/MeOH, 9:1. The crude product was triturated with DCM / EtOAc / heptane to give the title compound as a white solid (94 mg, 47\%). LC-MS (method A) tR $0.93 \mathrm{~min}, \mathrm{~m} / z .354 .1(100 \%, \mathrm{M}+\mathrm{H}), 132.9$ (100\%, pyrimidineNMe-H), 352.0 (100\%, M-H). ${ }^{1} \mathrm{H}$ NMR (400 MHz, DMSO-d6) $\delta 11.13(\mathrm{~s}, 1 \mathrm{H}), 8.77$ (d, $J=6.2 \mathrm{~Hz}, 1 \mathrm{H}$ ), $8.65(\mathrm{~s}, 1 \mathrm{H}), 7.83-7.79(\mathrm{~m}, 2 \mathrm{H}), 4.40-4.35(\mathrm{~m}, 2 \mathrm{H}), 3.76(\mathrm{~d}, J=5.9 \mathrm{~Hz}, 2 \mathrm{H}), 3.47$ (s, 3H), $3.36(\mathrm{~s}, 3 \mathrm{H})$.

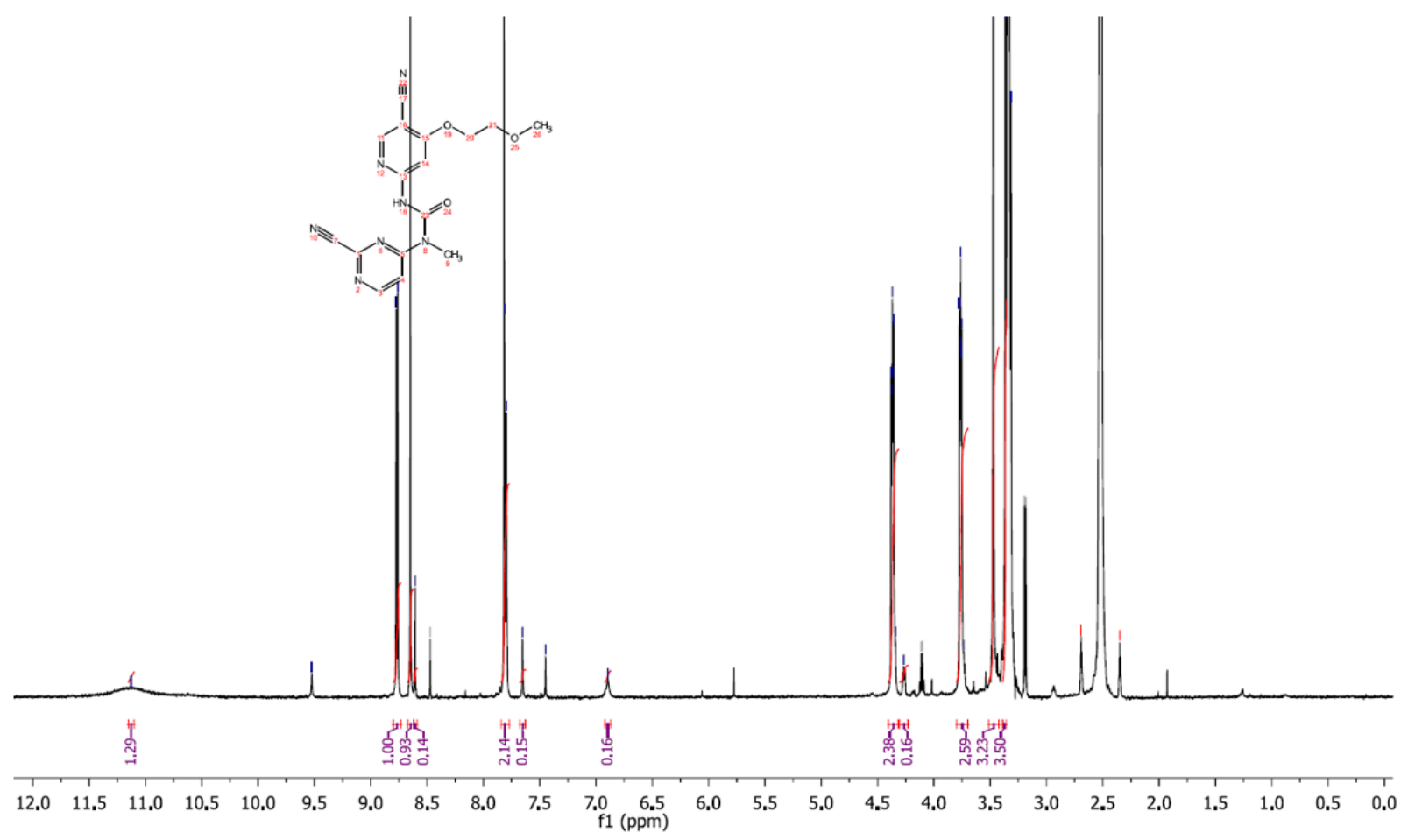


$\mathrm{N}$-(5-cyano-4-(2-(dimethylamino)ethoxy)pyridin-2-yl)-6-(formyl- $\left.{ }^{13} \mathrm{C}\right)-2,3$-dihydro-4H-pyrido[3,2-b][1,4]oxazine-4carboxamide 18

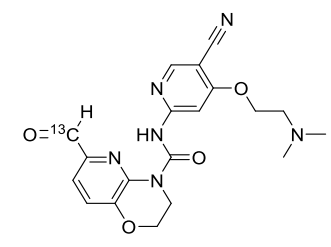

Synthetic sequence:
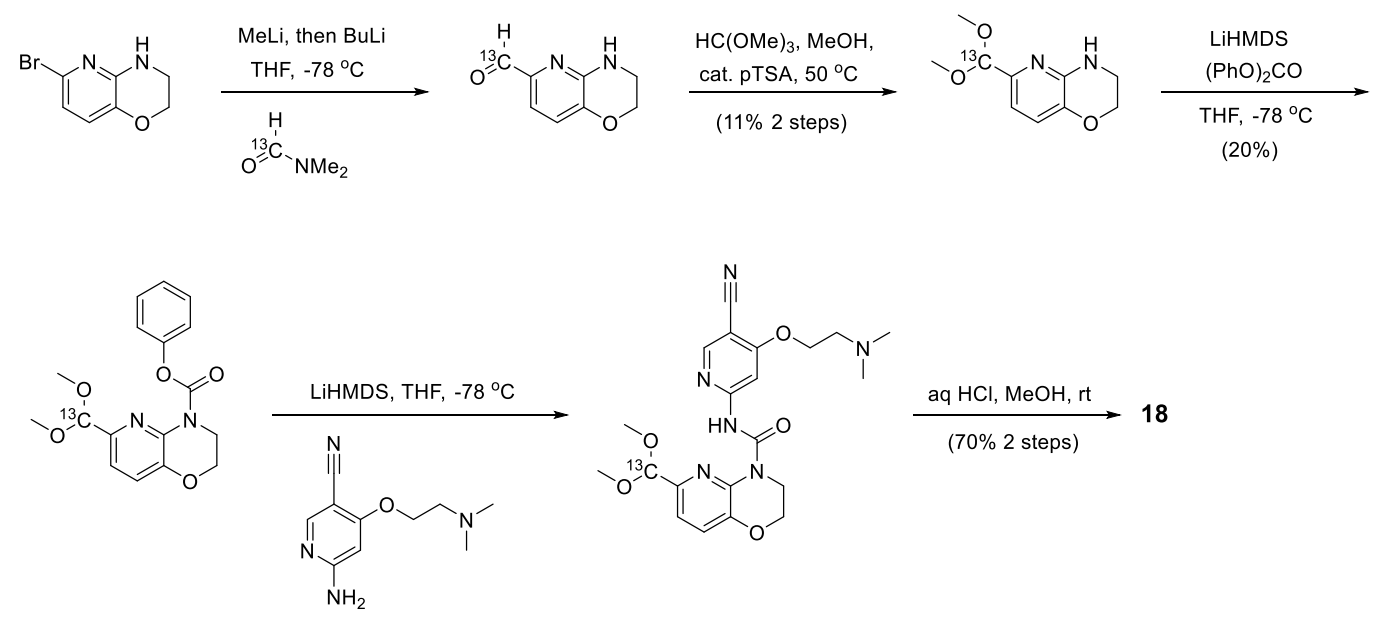

18: white solid, LC-MS (method A) tr $0.63 \mathrm{~min}, \mathrm{~m} / \mathrm{z} 398.2(100 \%, \mathrm{M}+\mathrm{H}), 396.2(100 \%, \mathrm{M}-\mathrm{H}) .{ }^{1} \mathrm{H} \mathrm{NMR}(400 \mathrm{MHz}$, chloroform- $\left.d_{1}\right)$ shows the hydrated form of the aldehyde as a minor component, $\delta 13.37(\mathrm{~s}, 1 \mathrm{H}), 10.05(\mathrm{~d}, J=181.1$ $\mathrm{Hz}, 1 \mathrm{H}), 8.39$ (s, 1H), 7.92 (s,1H), 7.73 (dd, $J=8.2,1.8 \mathrm{~Hz}, 1 \mathrm{H}), 7.43$ (d, J = 8.1 Hz, 1H), $4.43-4.39$ (m, $2 \mathrm{H}), 4.30$ $(\mathrm{t}, J=5.6 \mathrm{~Hz}, 2 \mathrm{H}), 4.27-4.22(\mathrm{~m}, 2 \mathrm{H}), 2.85(\mathrm{t}, J=5.6 \mathrm{~Hz}, 2 \mathrm{H}), 2.38(\mathrm{~s}, 6 \mathrm{H})$. 


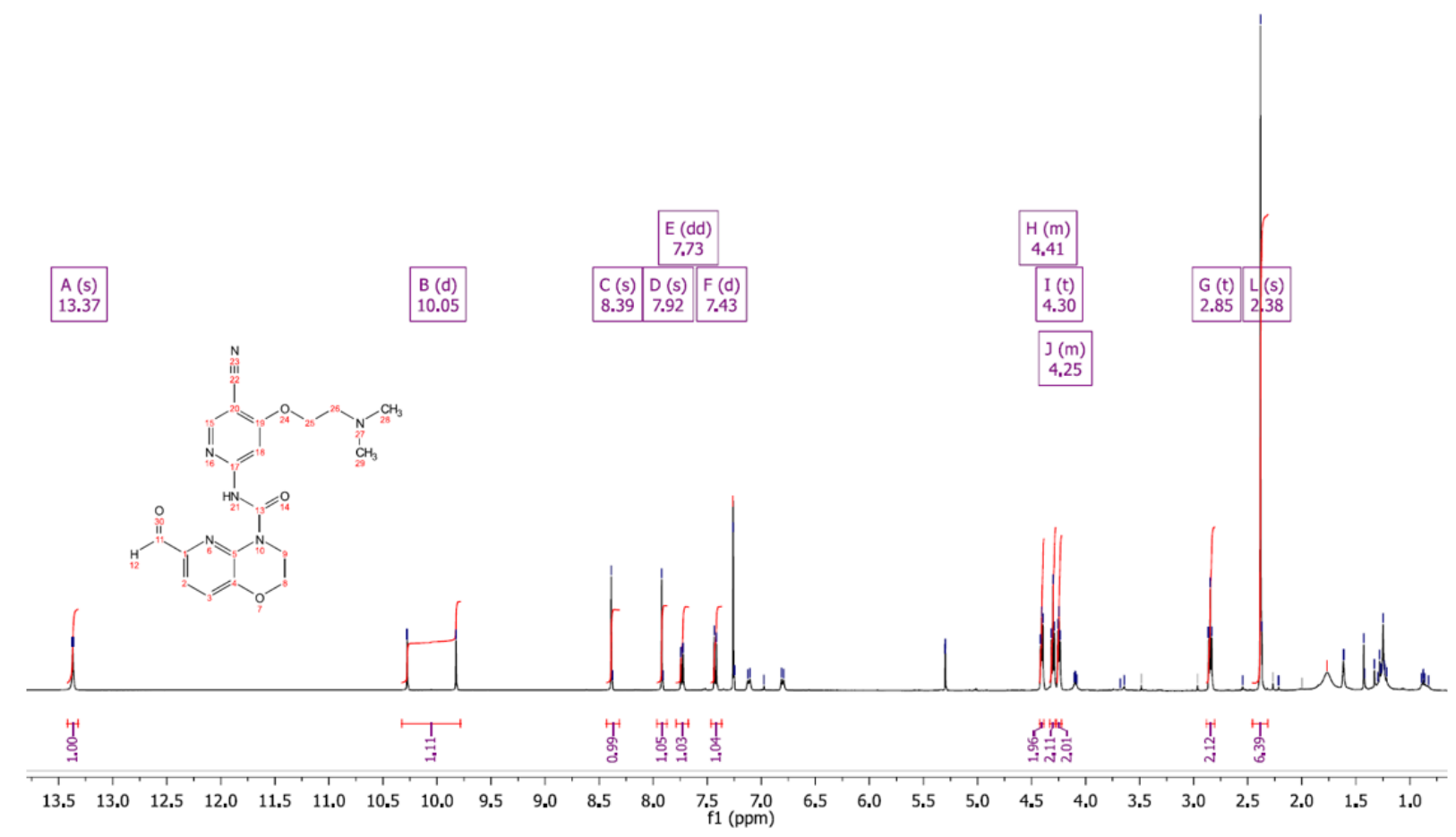


2-formyl-3-hydroxy- $N$-(5-(trifluoromethyl)pyridin-2-yl)quinoline-8-carboxamide 32

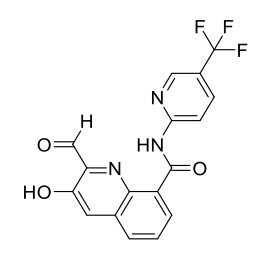

Synthetic sequence:

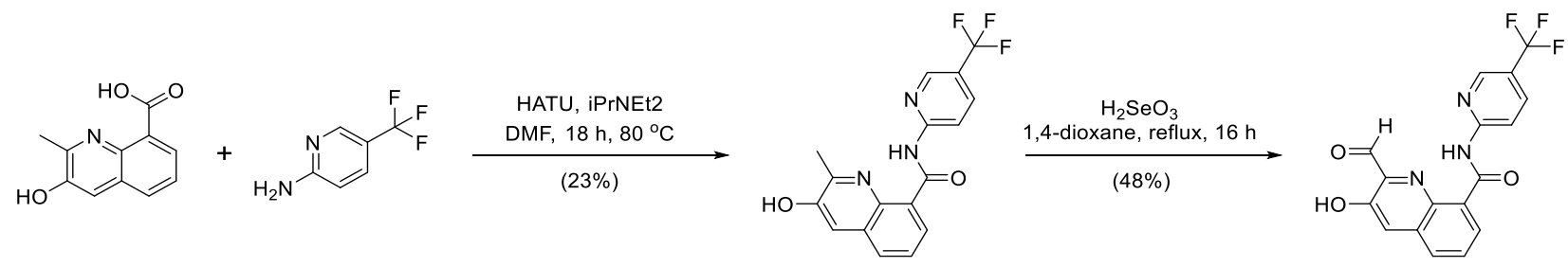

Step 1: A mixture of 3-hydroxy-2-methylquinoline-8-carboxylic acid ${ }^{\mathrm{S} 10}$ (230 mg, $1.13 \mathrm{mmol}$ ), 2-amino-5(trifluoromethyl)pyridine (183 mg, $1.13 \mathrm{mmol})$, HATU ( $861 \mathrm{mg}, 2.26 \mathrm{mmol}$ ) and DIPEA (395 $\mu \mathrm{l}, 2.26 \mathrm{mmol})$ in DMF $(5 \mathrm{ml})$ was stirred in a sealed tube at $80{ }^{\circ} \mathrm{C}$ for $18 \mathrm{~h}$. Water was added to the cooled reaction mixture and the precipitate collected by filtration and washed with water to give a brown solid. The crude product was absorbed onto isolute silica sorbent from a DCM solution and purified via normal phase chromatography using a $12 \mathrm{~g}$ silica column, eluting with a gradient of ethyl acetate in heptane $0-100 \%$ to give 3-hydroxy-2-methyl- $N$-(5-(trifluoromethyl)pyridin-2yl)quinoline-8-carboxamide as a pale yellow solid. LC-MS (method B) tR $1.19 \mathrm{~min}, \mathrm{~m} / \mathrm{z} 348.1(100 \%, \mathrm{M}+\mathrm{H}), 346.0$ (100\%, M-H). ${ }^{1} \mathrm{H}$ NMR (400 MHz, DMSO- $\left.d_{6}\right)$ :

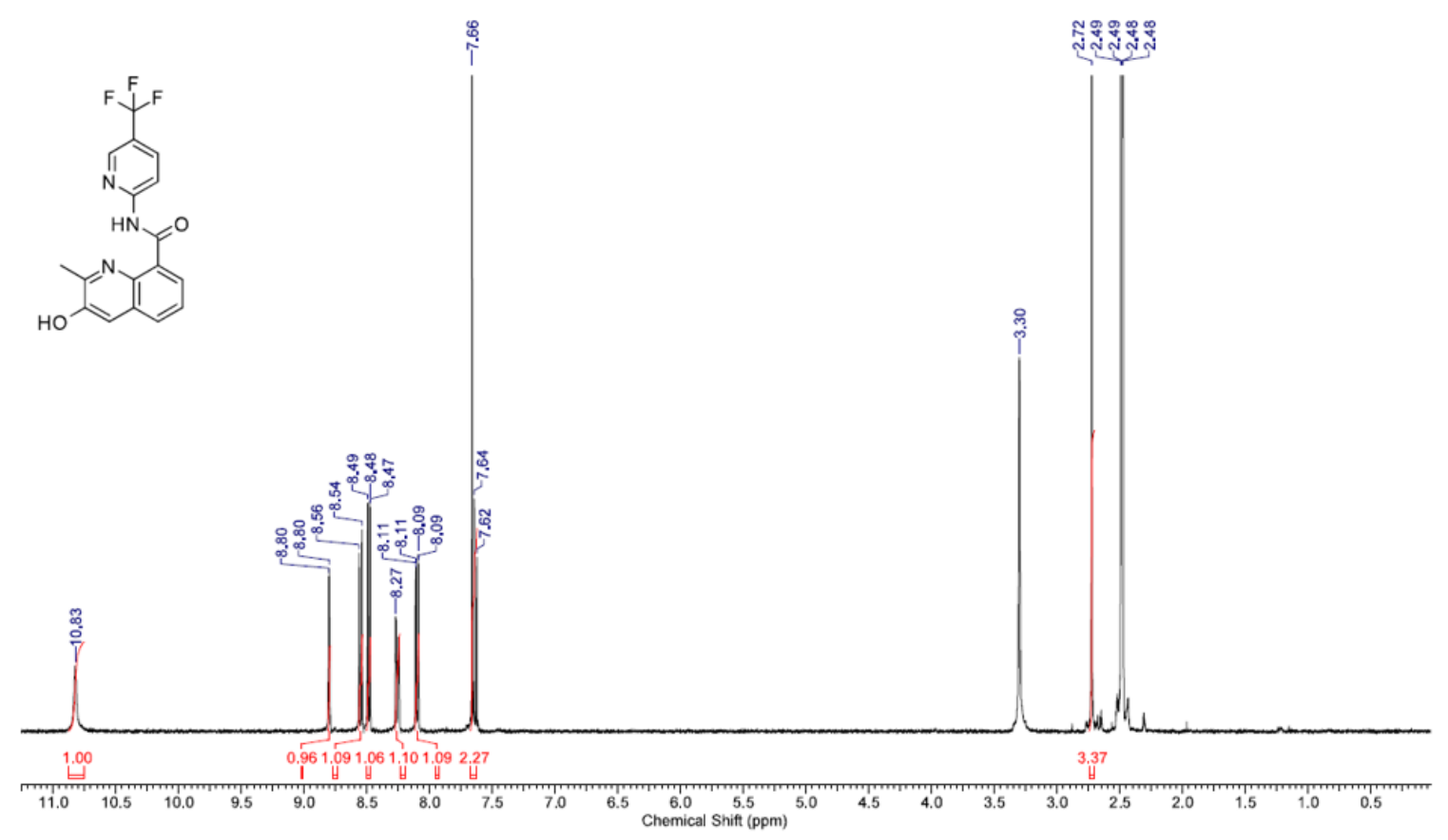


Step 2: Selenous acid (66.9 $\mathrm{mg}, 0.518 \mathrm{mmol})$ was added to a solution of 3-hydroxy-2-methyl- $N$-(5(trifluoromethyl)pyridin-2-yl)quinoline-8-carboxamide $(90 \mathrm{mg}, 0.26 \mathrm{mmol})$ in 1,4-dioxane $(2 \mathrm{ml})$ and the mixture sealed in a vial under argon and stirred at $110{ }^{\circ} \mathrm{C}$ for $18 \mathrm{~h}$. The cooled reaction mixture was diluted with EtOAc and washed with water followed by brine. The combined aqueous layers were re-extracted with EtOAc, the combined organic layers dried over $\mathrm{Na}_{2} \mathrm{SO}_{4}$ and evaporated. The crude product was absorbed onto isolute silica sorbent and purified via normal phase chromatography using a $24 \mathrm{~g}$ silica column, eluting with a gradient of ethyl acetate in heptane $0-100 \%$ to give the title compound as a yellow solid. LC-MS (method B) tR $1.19 \mathrm{~min}, \mathrm{~m} / \mathrm{z} .362 .1(100 \%$, $\mathrm{M}+\mathrm{H}), 360.0(100 \%, \mathrm{M}-\mathrm{H}) .{ }^{1} \mathrm{H}$ NMR (400 MHz, DMSO-d6): $\delta 13.81(\mathrm{~s}, 1 \mathrm{H}, \mathrm{NH}), 11.29$ (s, $\left.1 \mathrm{H}, \mathrm{OH}\right), 10.43$ (s, $1 \mathrm{H}$, $\mathrm{C}(\mathrm{O}) \mathrm{H}), 8.86-8.84$ (m, 1H, Ar H), $8.62-8.55$ (m, 2H, Ar H), $8.33-8.28$ (m, 1H, Ar H), 8.27 - 8.23 (m, $1 \mathrm{H}, \mathrm{Ar} \mathrm{H})$, 8.07 (s, 1H, Ar H), $7.88-7.82$ (m, 1H, Ar H).

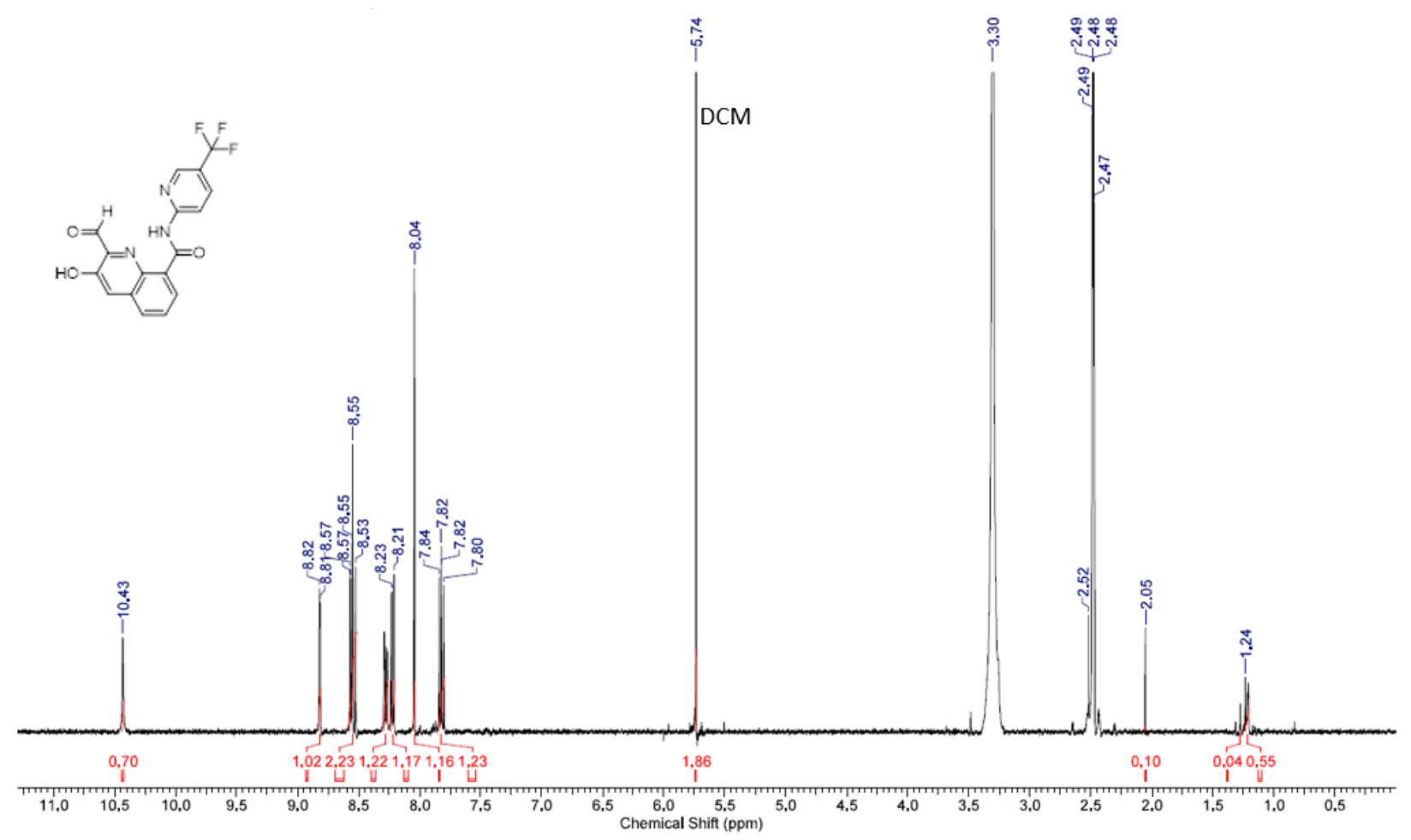




\section{Figure 13 and Table 5}

\section{LC/MS observations}

Some of the compound, inparticular with electron-withdrawing 3-substituents, show additional peaks by LC/MS consistent with the corresponding hydrates, and when the samples for injection are prepared in alcohols the corresponding hemiacetals are also typically observed. An example of a chromatogram in which the equilibrium between the aldehyde and hydrate is observed is shown below for compound $\mathbf{4 1}$ below:

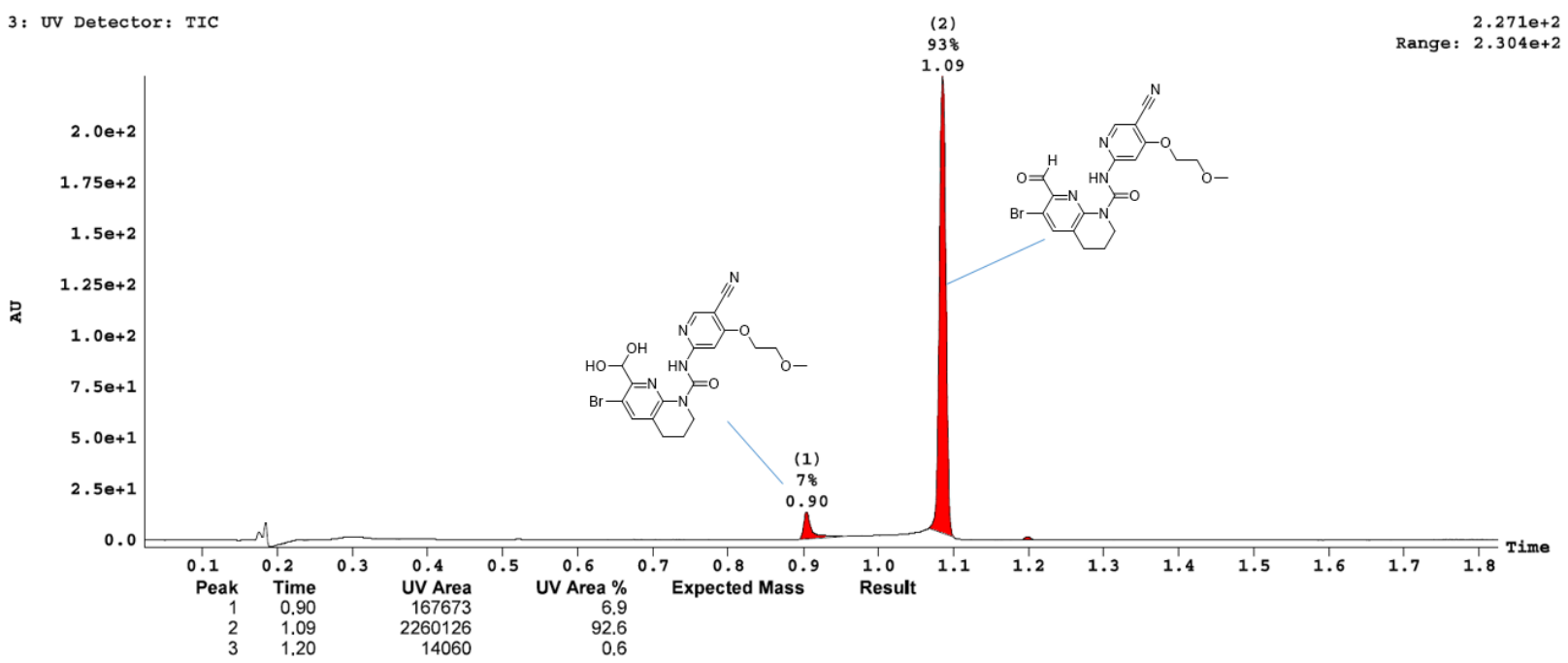

\begin{tabular}{|c|c|c|}
\hline Compound & Analytical data & Synthesis method $^{\mathrm{S} 11}$ \\
\hline 33 & $\begin{array}{l}\text { White solid. LC/MS (Method B): tR } 1.10 \mathrm{~min}, \mathrm{~m} / \mathrm{z} 322.1(100 \% \text {, } \\
\qquad \mathrm{M}+\mathrm{H}), 320.1(100 \%, \mathrm{M}-\mathrm{H}) .\end{array}$ & Aza anion urea formation \\
\hline 34 & $\begin{array}{l}\text { Pale yellow solid. LC/MS (Method B): } \mathrm{t}_{\mathrm{R}} 0.94 \mathrm{~min}, \mathrm{~m} / \mathrm{z} 323.1 \\
(100 \%, \mathrm{M}+\mathrm{H}), 321.1(75 \%, \mathrm{M}-\mathrm{H}), 367.1\left(\mathrm{M}+\mathrm{HCO}_{2}{ }^{-}\right)\end{array}$ & Aza anion urea formation \\
\hline 35 & $\begin{array}{l}\text { Pale yellow solid. LC/MS (Method B): } \mathrm{t}_{\mathrm{R}} 0.92 \mathrm{~min}, \mathrm{~m} / \mathrm{z} 338.1 \\
\qquad(100 \%, \mathrm{M}+\mathrm{H}), 336.0(100 \%, \mathrm{M}-\mathrm{H}) .\end{array}$ & Aza anion urea formation \\
\hline 36 & $\begin{array}{l}\text { White solid. LC/MS (Method A): } \mathrm{t}_{\mathrm{R}} 0.81 \mathrm{~min} \text { broad peak, } \mathrm{m} / z .338 .1 \\
(100 \%, \mathrm{M}+\mathrm{H}), 360.1\left(25 \%, \mathrm{M}+\mathrm{Na}^{+}\right), 336.1(100 \%, \mathrm{M}-\mathrm{H}) .\end{array}$ & Aza anion urea formation \\
\hline 37 & $\begin{array}{l}\text { White solid. LC/MS (Method B): tR } 1.04 \mathrm{~min}, \mathrm{~m} / z \text { 342.0/344.0 } \\
\qquad(100 \%, \mathrm{M}+\mathrm{H}), 340.0 / 342.0(100 \%, \mathrm{M}-\mathrm{H})\end{array}$ & $\begin{array}{l}\text { Oxalyl chloride urea } \\
\quad \text { formation }^{\mathrm{S} 12}\end{array}$ \\
\hline
\end{tabular}




\begin{tabular}{|c|c|c|}
\hline 38 & $\begin{array}{l}\text { White solid. LC/MS (Method A): tR } 1.17 \mathrm{~min}, \mathrm{~m} / z 348.1(100 \%, \\
\qquad \mathrm{M}+\mathrm{H}), 370.1\left(10 \%, \mathrm{M}+\mathrm{Na}^{+}\right), 346.1(100 \%, \mathrm{M}-\mathrm{H}) .\end{array}$ & Aza anion urea formation \\
\hline 39 & $\begin{array}{l}\text { White solid. LC/MS (Method A): } \mathrm{t}_{\mathrm{R}} 0.61 \mathrm{~min}, \mathrm{~m} / \mathrm{z} 365.1(100 \% \text {, } \\
\qquad \mathrm{M}+\mathrm{H}), 363.2(100 \%, \mathrm{M}-\mathrm{H}) .\end{array}$ & Aza anion urea formation \\
\hline 40 & $\begin{array}{l}\text { White solid. LC/MS (Method A): tr } 0.86 \mathrm{~min}, \mathrm{~m} / z 365.1(100 \% \text {, } \\
\qquad \mathrm{M}+\mathrm{H}), 388.1\left(10 \%, \mathrm{M}+\mathrm{Na}^{+}\right), 320.2\left(100 \%, \mathrm{M}-\mathrm{CO}_{2} \mathrm{H}\right) .\end{array}$ & Aza anion urea formation \\
\hline 41 & $\begin{array}{l}\text { White solid. LC/MS (Method A): } t_{R} 0.90 \text { and } 1.09 \text { min broad double- } \\
\text { peak, hydrate } 0.90 \min m / z 460.3 / 462.3\left(20 \%, M-\mathrm{H}_{2} \mathrm{O}+\mathrm{H}\right), \\
478.2 / 480.2(100 \%, \mathrm{M}+\mathrm{H}), 458.1 / 460.1\left(100 \%, \mathrm{M}-\mathrm{H}_{2} \mathrm{O}-\mathrm{H}\right), \\
476.2 / 478.0(95 \%, \mathrm{M}-\mathrm{H}) \text {, aldehyde } 1.09 \mathrm{~min} \mathrm{~m} / \mathrm{z} 460.2 / 462.2(100 \% \\
\mathrm{M}+\mathrm{H}), 458.1 / 460.1(100 \%, \mathrm{M}-\mathrm{H}) .\end{array}$ & Aza anion urea formation \\
\hline 42 & $\begin{array}{l}\text { White crystalline solid, mp } 181{ }^{\circ} \mathrm{C}(\mathrm{DSC}) . \mathrm{LC} / \mathrm{MS}(\text { Method } \mathrm{A}): \mathrm{t}_{\mathrm{R}} \\
0.86 \mathrm{~min} \text { broad peak, } \mathrm{m} / \mathrm{z} 412.1(100 \%, \mathrm{M}+\mathrm{H}), 410.1(100 \%, \mathrm{M}-\mathrm{H}) .\end{array}$ & Aza anion urea formation \\
\hline 43 & $\begin{array}{c}\text { White crystalline solid, mp } 171{ }^{\circ} \mathrm{C}(\mathrm{DSC}) . \mathrm{LC} / \mathrm{MS}(\text { Method } \mathrm{A}): \mathrm{t}_{\mathrm{R}} \\
0.82 \mathrm{~min} \text { broad peak, } m / z 411.2(100 \%, \mathrm{M}+\mathrm{H}), 217.1(100 \% \\
\text { pyridineNCO-H), } 409.2(25 \%, \mathrm{M}-\mathrm{H}) .\end{array}$ & $\begin{array}{l}\text { Aza anion urea formation } \\
\text { with } 2.2 \text { equiv. LiHMDS }\end{array}$ \\
\hline 44 & $\begin{array}{l}\text { Light-brown solid. LC/MS (Method A): } \mathrm{t}_{\mathrm{R}} 1.13 \mathrm{~min}, \mathrm{~m} / \mathrm{z} 426.2 \\
(100 \%, \mathrm{M}+\mathrm{H}), 424.3(25 \%, \mathrm{M}-\mathrm{H}) .\end{array}$ & Aza anion urea formation \\
\hline 45 & $\begin{array}{l}\text { Light-brown solid. LC/MS (Method A): tR } 1.16 \mathrm{~min}, \mathrm{~m} / z 432.2 \\
(100 \%, \mathrm{M}+\mathrm{H}), 430.2(25 \%, \mathrm{M}-\mathrm{H}) .\end{array}$ & Aza anion urea formation \\
\hline 46 & $\begin{array}{l}\left.\text { White crystalline solid, mp } 202{ }^{\circ} \mathrm{C}(\mathrm{DSC}) . \mathrm{LC} / \mathrm{MS} \text { (Method } \mathrm{A}\right): \mathrm{t}_{\mathrm{R}} \\
0.87 \text { and } 1.14 \mathrm{~min} \text { double-peak, hydrate } 0.87 \mathrm{~min} \mathrm{~m} / \mathrm{z} 449.3(100 \% \text {, } \\
\mathrm{M}+\mathrm{H}) \text {, aldehyde } 1.14 \mathrm{~min} \mathrm{~m} / \mathrm{z} 431.3(100 \% \mathrm{M}+\mathrm{H}), 217.1(100 \% \text {, } \\
\text { pyridineNCO-H), } 429.1(35 \%, \mathrm{M}-\mathrm{H}), 475.2\left(30 \%, \mathrm{M}^{-\mathrm{HCO}_{2}}\right) .\end{array}$ & $\begin{array}{l}\text { Aza anion urea formation } \\
\text { with } 2.0 \text { equiv. LiHMDS }\end{array}$ \\
\hline 47 & $\begin{array}{l}\text { White solid. LC/MS (Method A): tR } 0.98 \text { and } 1.17 \text { min double-peak, } \\
\text { hydrate } 0.98 \mathrm{~min} \mathrm{~m} / \mathrm{z} 468.2(100 \%, \mathrm{M}+\mathrm{H}), 448.2\left(40 \%, \mathrm{M}-\mathrm{H}_{2} \mathrm{O}-\mathrm{H}\right) \text {, } \\
466.1(100 \%, \mathrm{M}-\mathrm{H}) \text {, aldehyde } 1.17 \mathrm{~min} \mathrm{~m} / \mathrm{z} 450.2(100 \% \mathrm{M}+\mathrm{H}) \text {, } \\
448.2(100 \%, \mathrm{M}-\mathrm{H}) .\end{array}$ & Aza anion urea formation \\
\hline 48 & $\begin{array}{l}\text { White crystalline solid, mp } 210{ }^{\circ} \mathrm{C}(\mathrm{DSC}) . \mathrm{LC} / \mathrm{MS}(\text { Method } \mathrm{A}): \mathrm{t}_{\mathrm{R}} \\
1.00 \mathrm{~min} \text { single peak with front tail, } \mathrm{m} / \mathrm{z} 478.2(100 \%, \mathrm{M}+\mathrm{H}), 217.1 \\
(100 \% \text {, pyridineNCO-H), } 476.4(10 \%, \mathrm{M}-\mathrm{H}) .\end{array}$ & $\begin{array}{l}\text { Aza anion urea formation } \\
\text { with } 2.2 \text { equiv. LiHMDS }\end{array}$ \\
\hline 49 & $\begin{array}{l}\text { Pale-yellow solid. LC/MS (Method A): tR } 0.93 \text { min single peak with } \\
\text { front tail, } m / z 461.2(100 \%, M+H),\end{array}$ & $\begin{array}{l}\text { Aza anion urea formation } \\
\text { with } 2.2 \text { equiv. LiHMDS }\end{array}$ \\
\hline
\end{tabular}




\begin{tabular}{|c|c|c|}
\hline 50 & $\begin{array}{c}\text { White solid. LC/MS (Method A): tR } 0.91 \text { min single peak with front } \\
\text { tail, } m / z \text { 458.1 }(100 \%, \mathrm{M}+\mathrm{H}), 217.0(100 \% \text {, pyridineNCO-H), } 456.1 \\
(40 \%, \mathrm{M}-\mathrm{H}) .\end{array}$ & $\begin{array}{l}\text { Aza anion urea formation } \\
\text { with } 2.2 \text { equiv. LiHMDS }\end{array}$ \\
\hline 51 & $\begin{array}{l}\text { Beige solid. LC/MS (Method A): } t_{R} 0.74 \text { min single peak with front } \\
\text { tail, } m / z 461.1(100 \%, M+H), 217.0(100 \% \text {, pyridineNCO-H), } 459.0 \\
(30 \%, M-H) .\end{array}$ & $\begin{array}{l}\text { Aza anion urea formation } \\
\text { with } 2.2 \text { equiv. LiHMDS }\end{array}$ \\
\hline 52 & $\begin{array}{l}\text { White crystalline solid. LC/MS (Method A): } \mathrm{t}_{\mathrm{R}} 1.06, \mathrm{~m} / \mathrm{z} 465.3 \\
\qquad(100 \%, \mathrm{M}+\mathrm{H}) .\end{array}$ & $\begin{array}{l}\text { Aza anion urea formation } \\
\text { with } 2.2 \text { equiv. LiHMDS }\end{array}$ \\
\hline 53 & $\begin{array}{l}\text { White solid. LC/MS (Method A): tR } 0.72 \text { min single peak with front } \\
\text { tail, } m / z 520.3(100 \%, \mathrm{M}+\mathrm{H}), 217.2(100 \% \text {, pyridineNCO-H), } 518.3 \\
(95 \%, \mathrm{M}-\mathrm{H}) .\end{array}$ & CDT urea formation \\
\hline 54 & $\begin{array}{c}\text { Pale-yellow solid. LC/MS (Method A): } t_{R} 0.80 \text { min single peak with } \\
\text { front tail, } m / z 480.2(100 \%, M+H), 217.1(100 \% \text {, pyridineNCO-H), } \\
478.2(20 \%, \mathrm{M}-\mathrm{H}) .\end{array}$ & CDT urea formation \\
\hline $57 / 58$ & $\begin{array}{l}\text { White crystalline solids, mp } 196{ }^{\circ} \mathrm{C}(\mathrm{DSC}) \text {. LC/MS (Method A): } \mathrm{t}_{\mathrm{R}} \\
0.85 \text { min broad peak, } m / z 424.2(100 \%, \mathrm{M}+\mathrm{H}), 422.3(95 \%, \mathrm{M}-\mathrm{H}) .\end{array}$ & $\begin{array}{l}\text { Aza anion urea formation } \\
\text { with } 2.2 \text { equiv. LiHMDS }\end{array}$ \\
\hline
\end{tabular}

Table S1 Analytical data and the urea bond forming approach used to prepare the compounds included in Figure 13 of the main text.

$400 \mathrm{MHz}{ }^{1} \mathrm{H}$ NMR in DMSO- $d_{6}$ of $N$-(5-cyanopyridin-2-yl)-7-formyl-6-methyl-3,4-dihydro-1,8naphthyridine-1(2H)-carboxamide $\mathbf{3 3}$

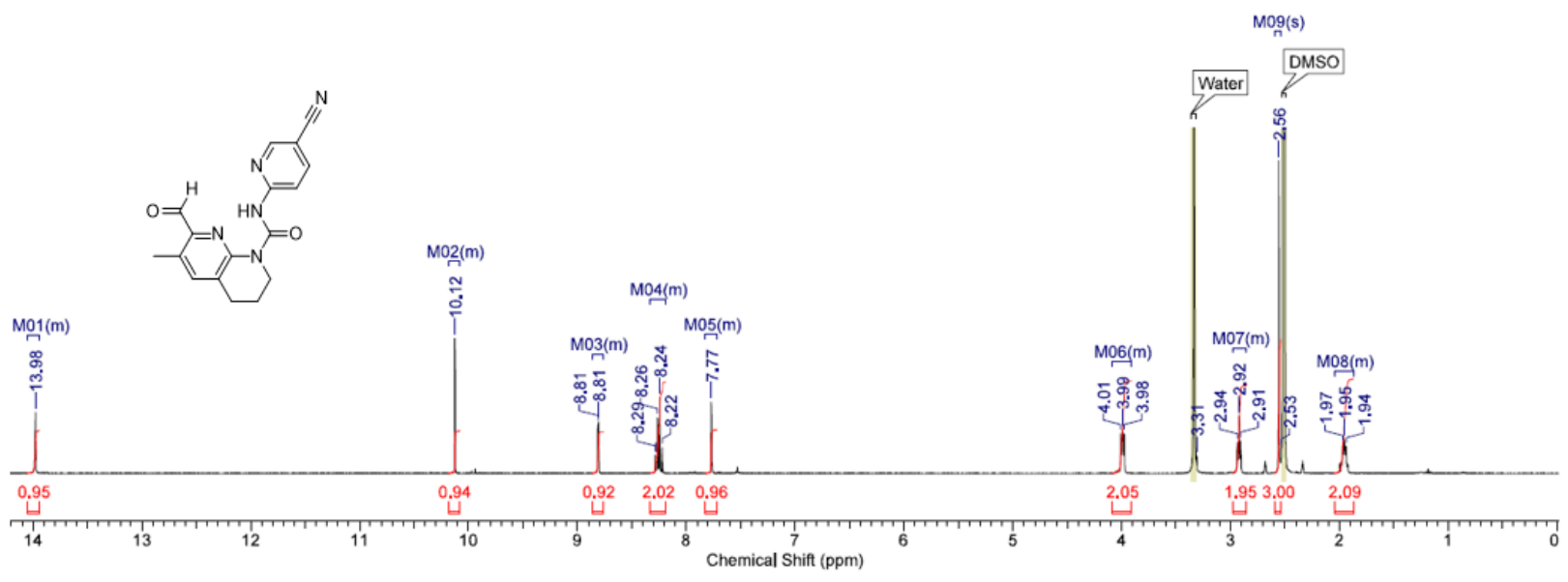


$400 \mathrm{MHz}{ }^{1} \mathrm{H}$ NMR in DMSO- $d_{6}$ of 6-amino- $N$-(5-cyanopyridin-2-yl)-7-formyl-3,4-dihydro-1,8-naphthyridine$1(2 H)$-carboxamide 34

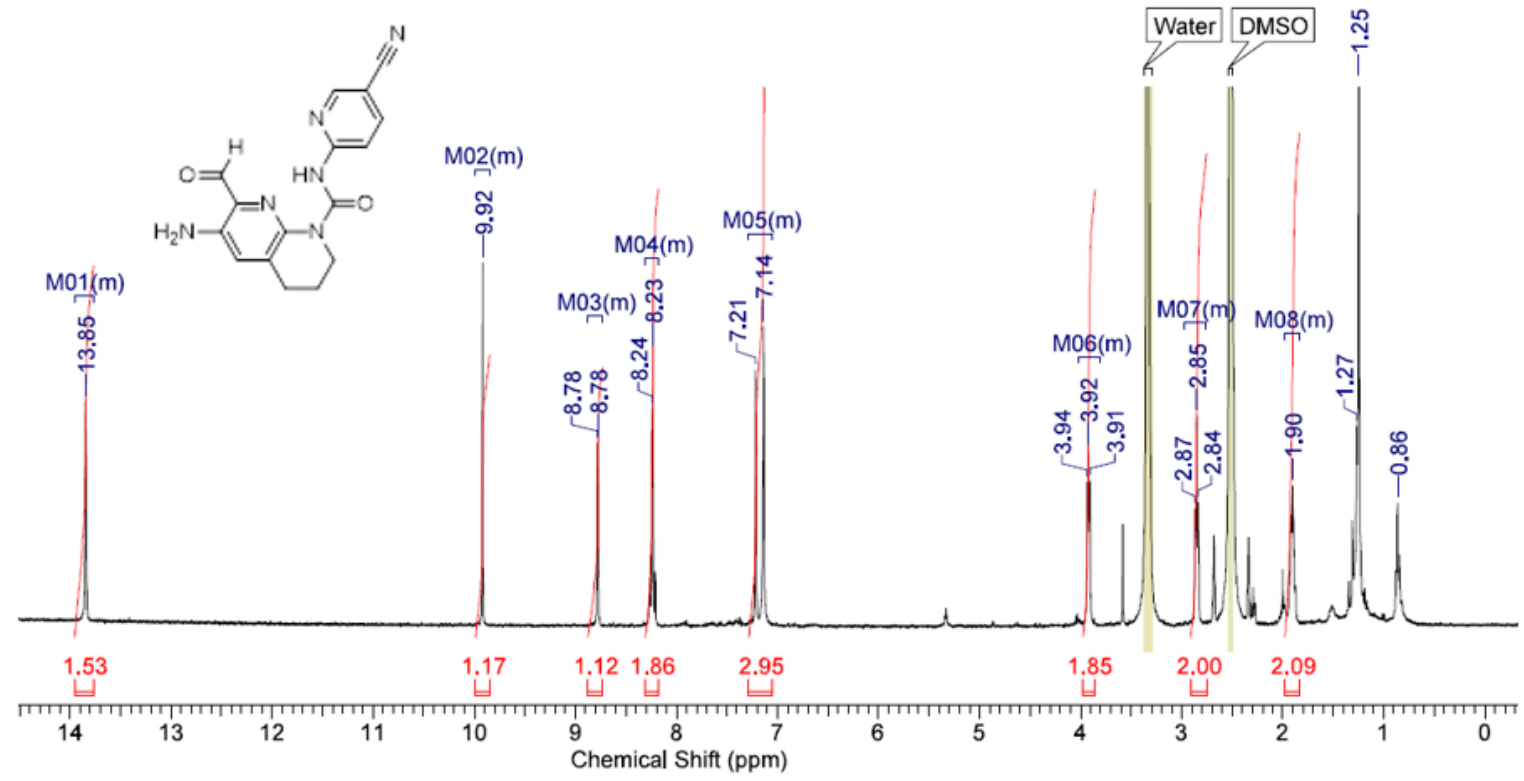

$400 \mathrm{MHz}^{1} \mathrm{H}$ NMR in DMSO- $d_{6}$ of $N$-(5-cyanopyridin-2-yl)-7-formyl-6-methoxy-3,4-dihydro-1,8-naphthyridine$\underline{1(2 H) \text {-carboxamide } 35}$

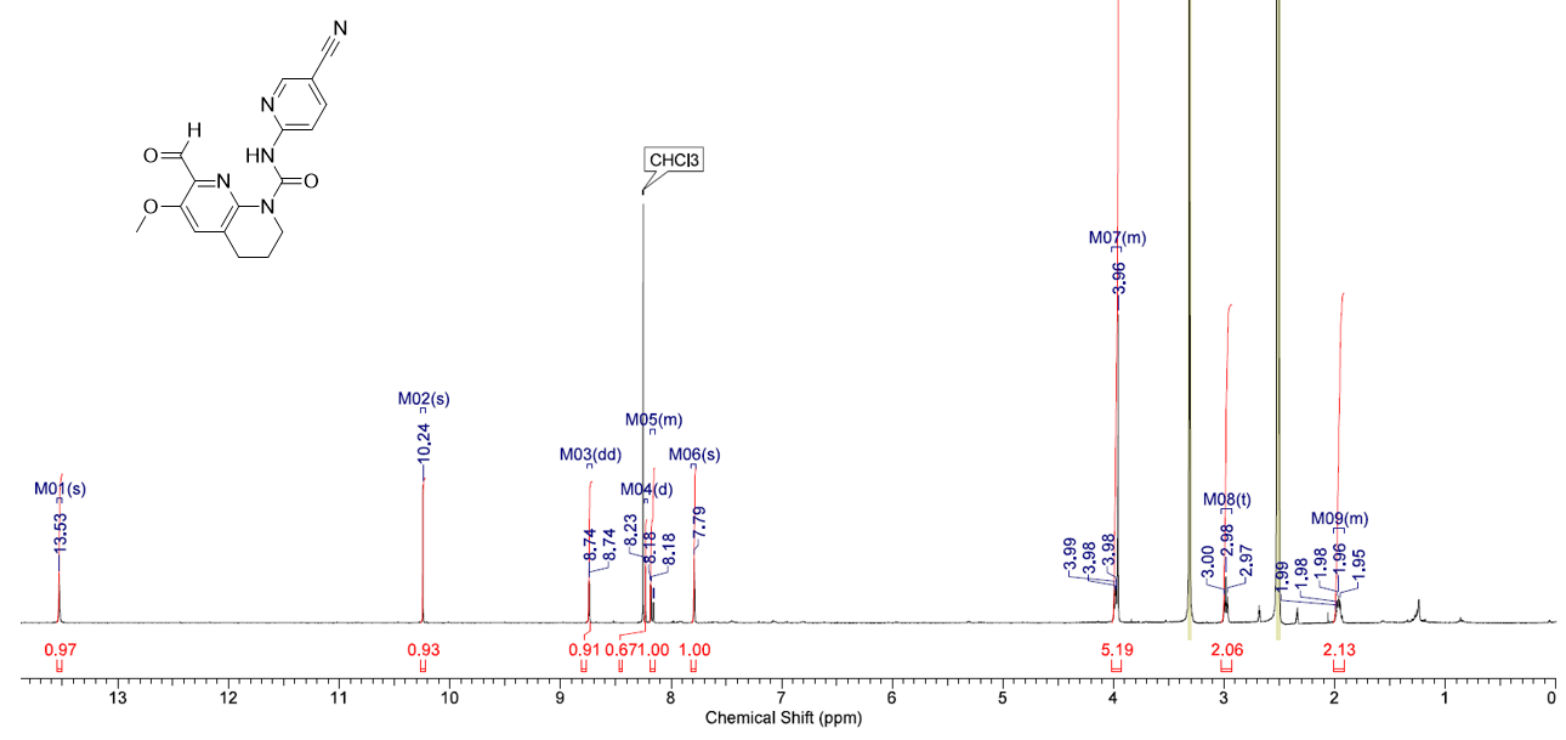


$400 \mathrm{MHz}{ }^{1} \mathrm{H}$ NMR in DMSO- $d_{6}$ of $N$-(5-cyanopyridin-2-yl)-7-formyl-6-(hydroxymethyl)-3,4-dihydro-1,8naphthyridine-1 $(2 H)$-carboxamide 36 (3:1 mixture of the internal hemiacetal and aldehyde tautomers)

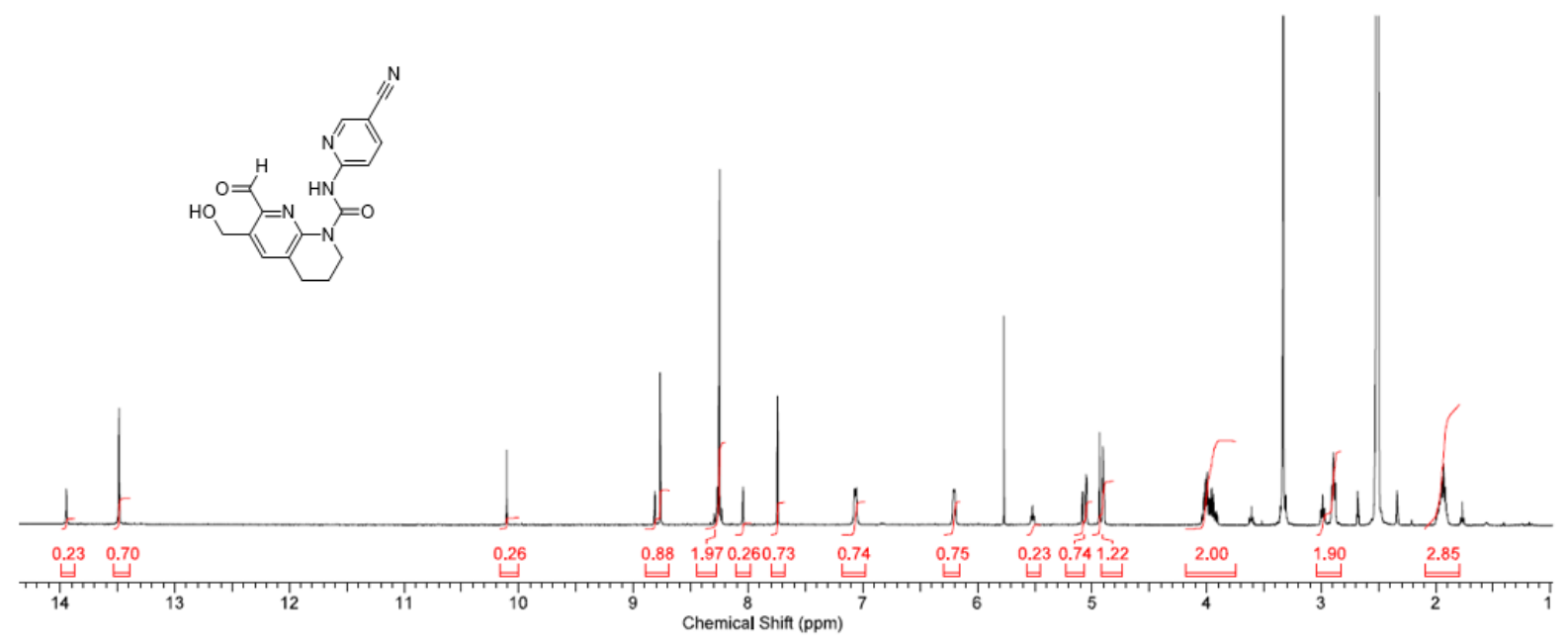

$400 \mathrm{MHz}{ }^{1} \mathrm{H}$ NMR in DMSO- $d_{6}$ of 6-chloro- $N$-(5-cyanopyridin-2-yl)-7-formyl-3,4-dihydro-1,8-naphthyridine$1(2 \mathrm{H})$-carboxamide 37 (obtained as 1:1 mixture of the methanol hemiacetal and aldehyde following normal phase chromatography eluting with a DCM/MeOH gradient)

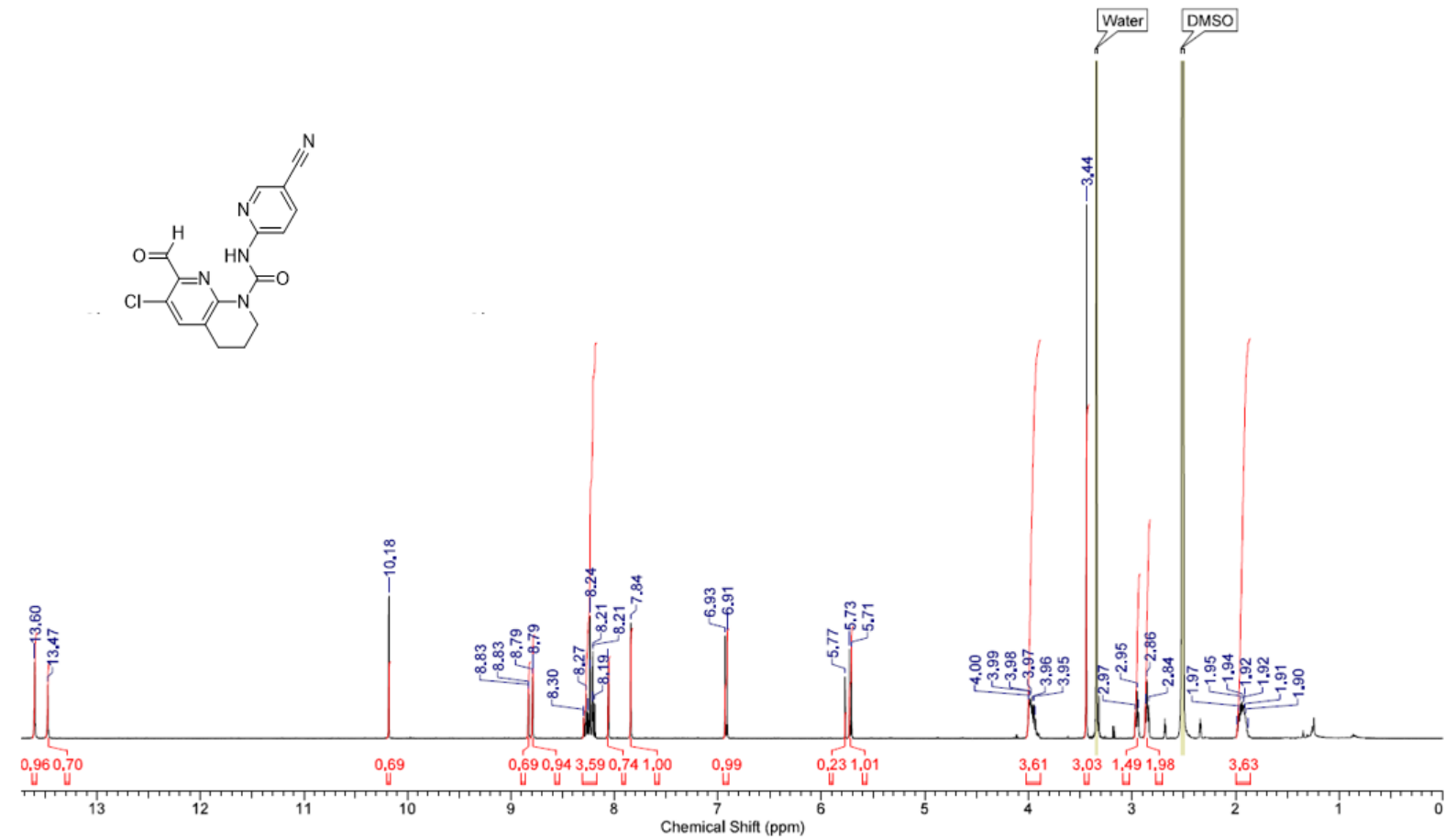


$400 \mathrm{MHz}{ }^{1} \mathrm{H}$ NMR in DMSO- $d_{6}$ of $N$-(5-cyanopyridin-2-yl)-6-cyclopropyl-7-formyl-3,4-dihydro-1,8-naphthyridine$1(2 H)$-carboxamide 38

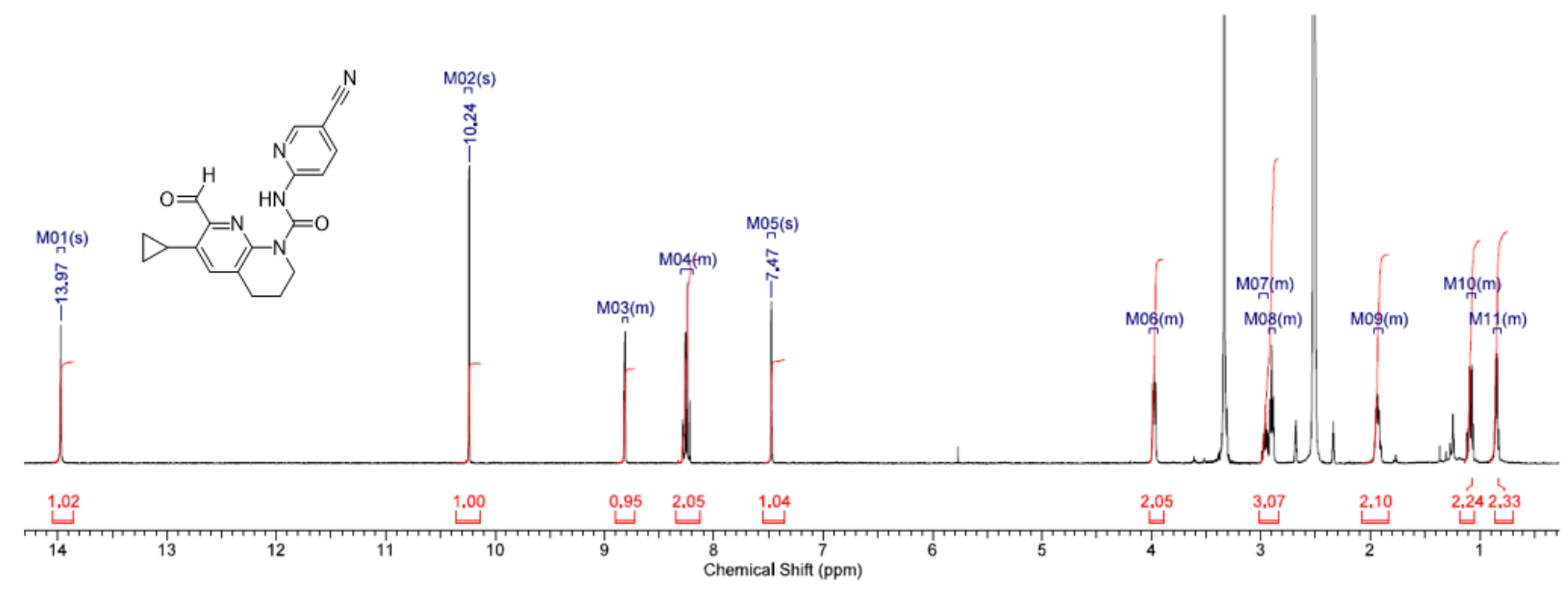

$400 \mathrm{MHz}{ }^{1} \mathrm{H}$ NMR in DMSO-d 6 of $N$-(5-cyanopyridin-2-yl)-6-((dimethylamino)methyl)-7-formyl-3,4-dihydro-1,8naphthyridine-1 $(2 H)$-carboxamide 39

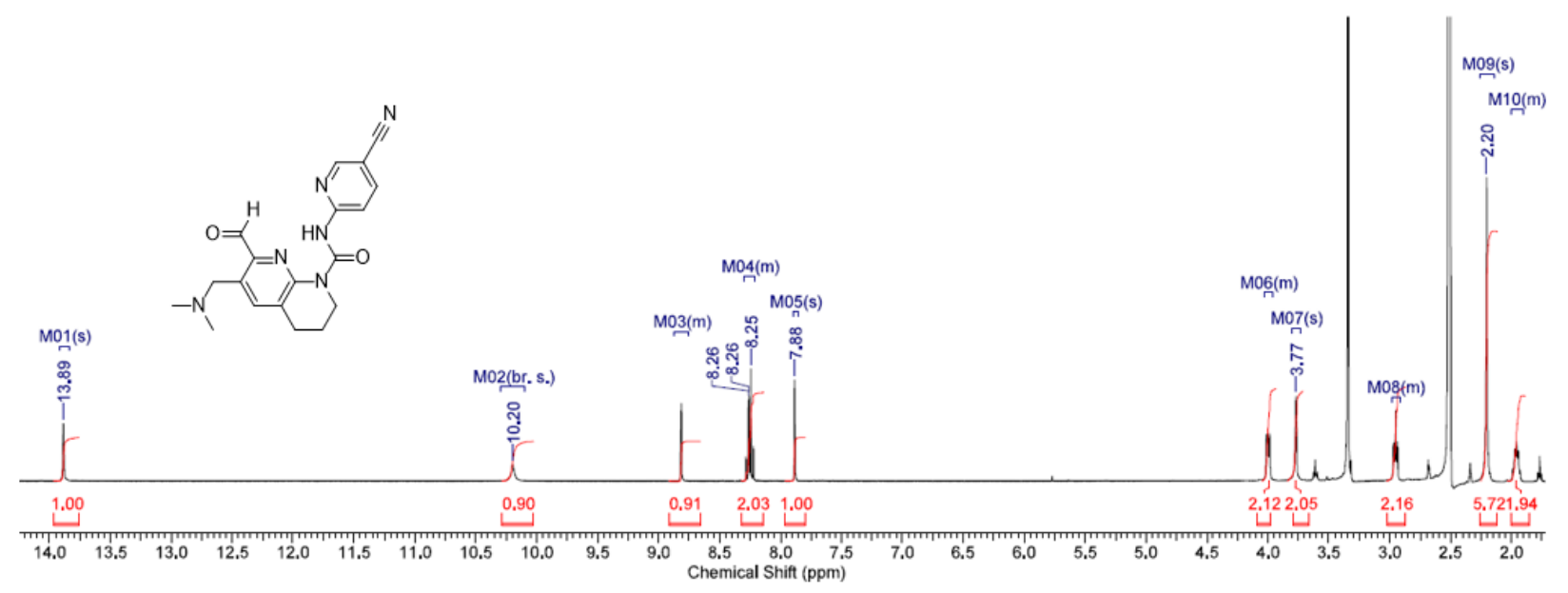


$400 \mathrm{MHz}{ }^{1} \mathrm{H}$ NMR in DMSO- $d_{6}$ of 2-(8-((5-cyanopyridin-2-yl)carbamoyl)-2-formyl-5,6,7,8-tetrahydro-1,8naphthyridin-3-yl)acetic acid 40

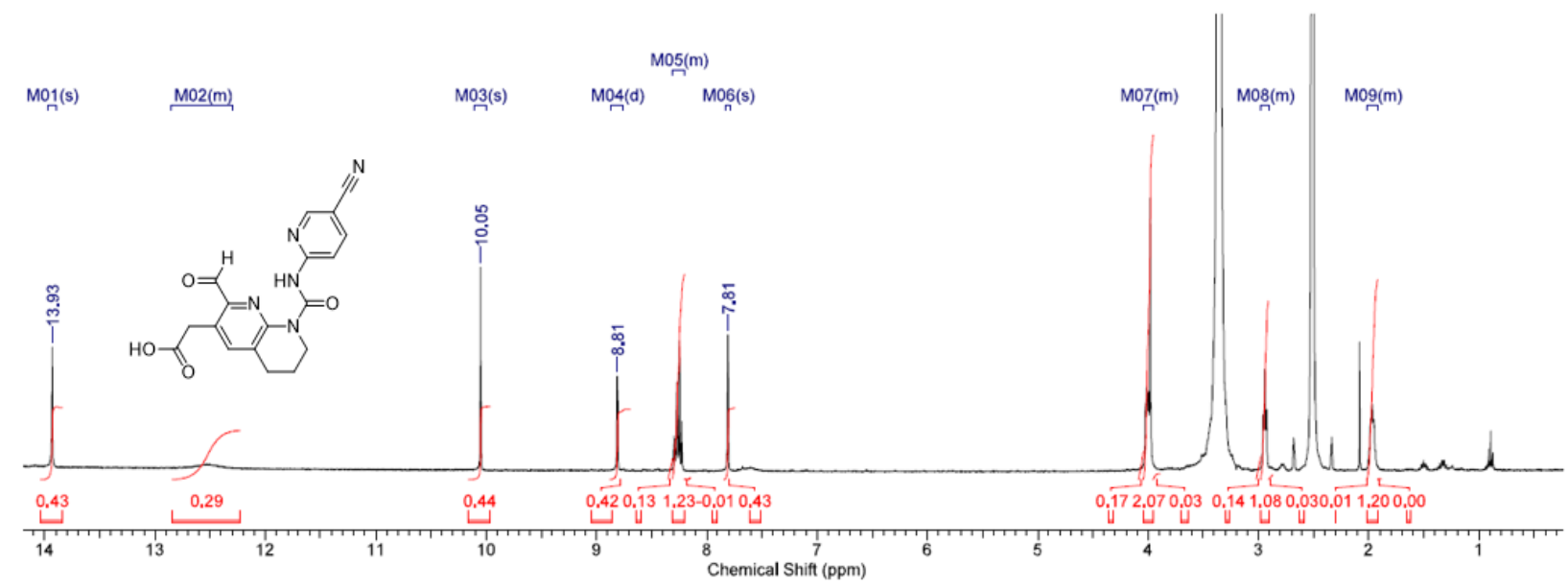

$400 \mathrm{MHz}^{1} \mathrm{H}$ NMR in DMSO- $d_{6}$ of 6-bromo- $N$-(5-cyano-4-(2-methoxyethoxy)pyridin-2-yl)-7-formyl-3,4-dihydro1,8-naphthyridine-1 $(2 H)$-carboxamide 41 (obtained as $2: 3$ mixture of the hydrate and aldehyde)

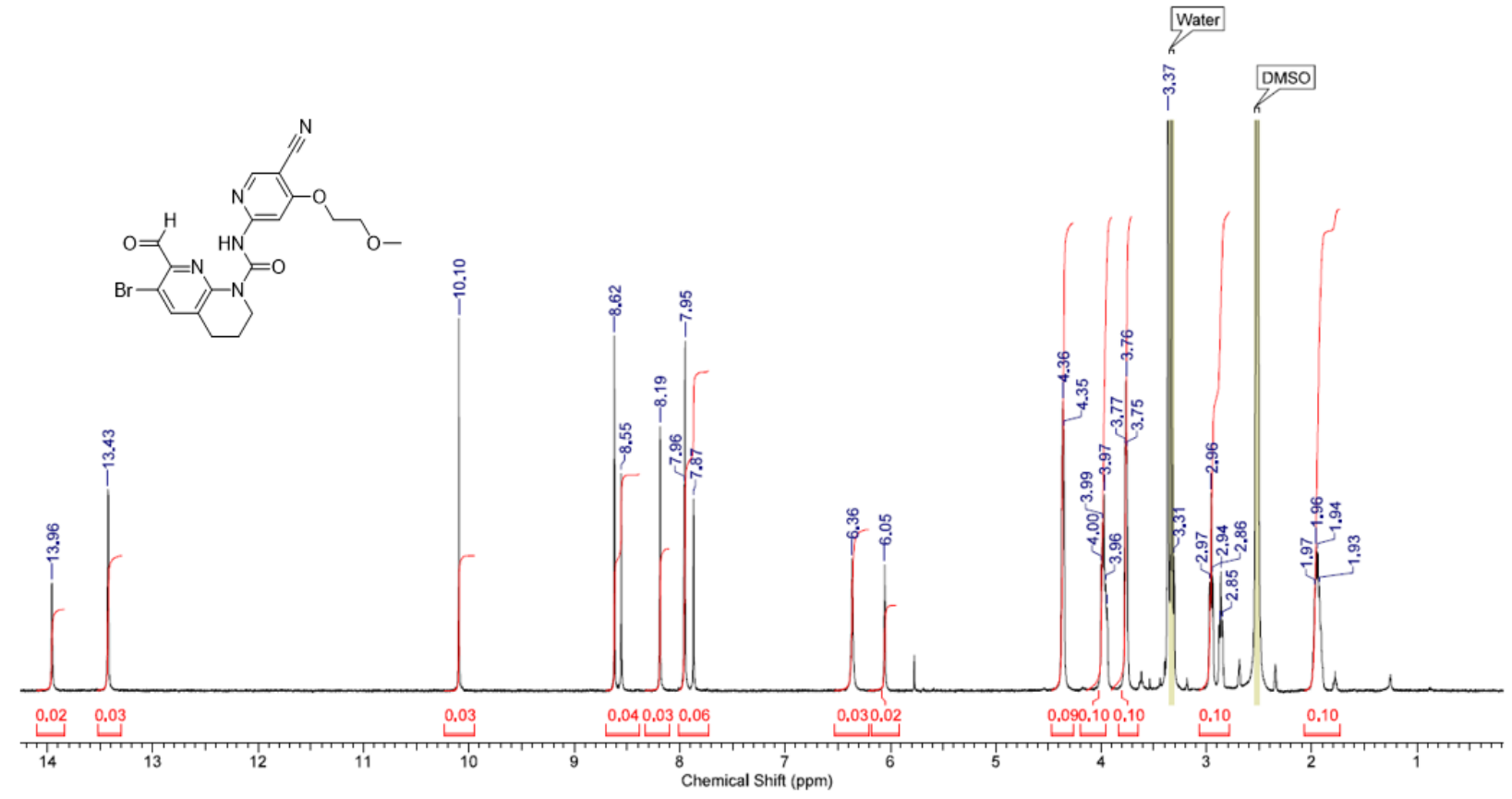


$400 \mathrm{MHz}{ }^{1} \mathrm{H}$ NMR in DMSO- $d_{6}$ of $N$-(5-cyano-4-(2-methoxyethoxy)pyridin-2-yl)-7-formyl-6-(hydroxymethyl)-3,4dihydro-1,8-naphthyridine-1 $(2 H)$-carboxamide 42 (3:1 mixture of the internal hemiacetal and aldehyde tautomers)

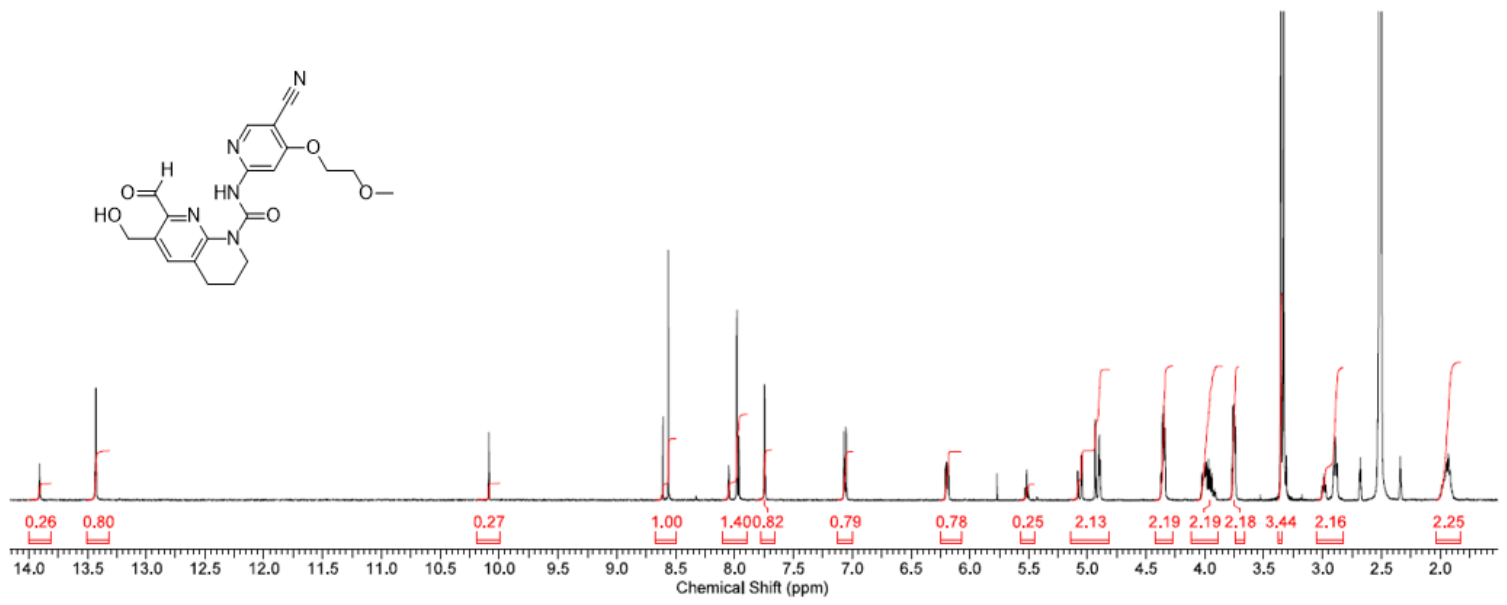

$400 \mathrm{MHz}{ }^{1} \mathrm{H},{ }^{13} \mathrm{C}$ HSQC NMR in DMSO- $d_{6}$ of $N$-(5-cyano-4-((2-methoxyethyl)amino)pyridin-2-yl)-7-formyl-6(hydroxymethyl)-3,4-dihydro-1,8-naphthyridine-1(2H)-carboxamide $\mathbf{4 3}$ (3:1 mixture of the internal hemiacetal and aldehyde tautomers)
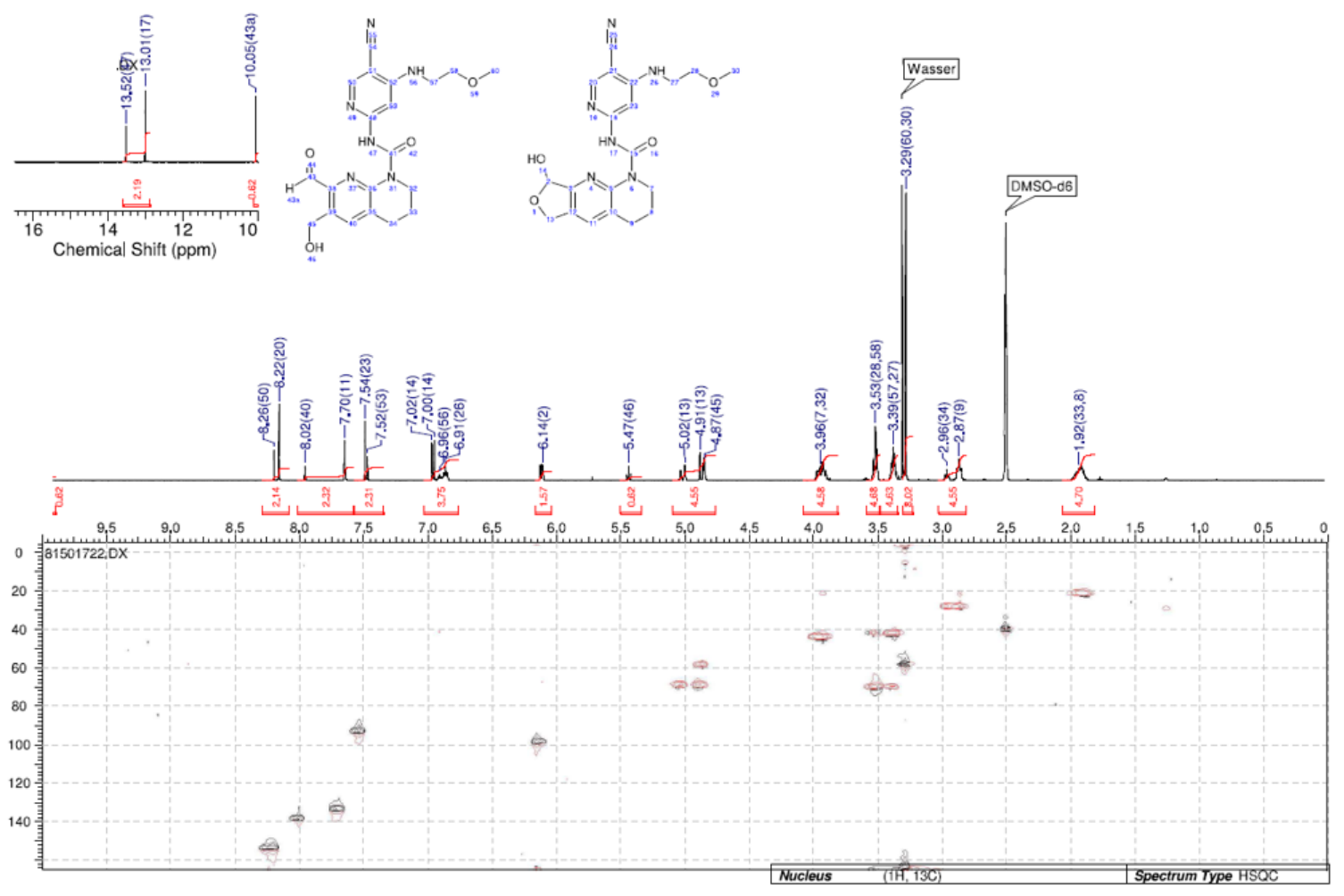
$101 \mathrm{MHz}{ }^{13} \mathrm{C}$ NMR in DMSO- $d_{6}$ of $N$-(5-cyano-4-((2-methoxyethyl)amino)pyridin-2-yl)-7-formyl-6-

(hydroxymethyl)-3,4-dihydro-1,8-naphthyridine-1 $(2 H)$-carboxamide $\mathbf{4 3}$ (doubling of some peaks due to a mixture of aldehyde and hemiacetal tautomers)

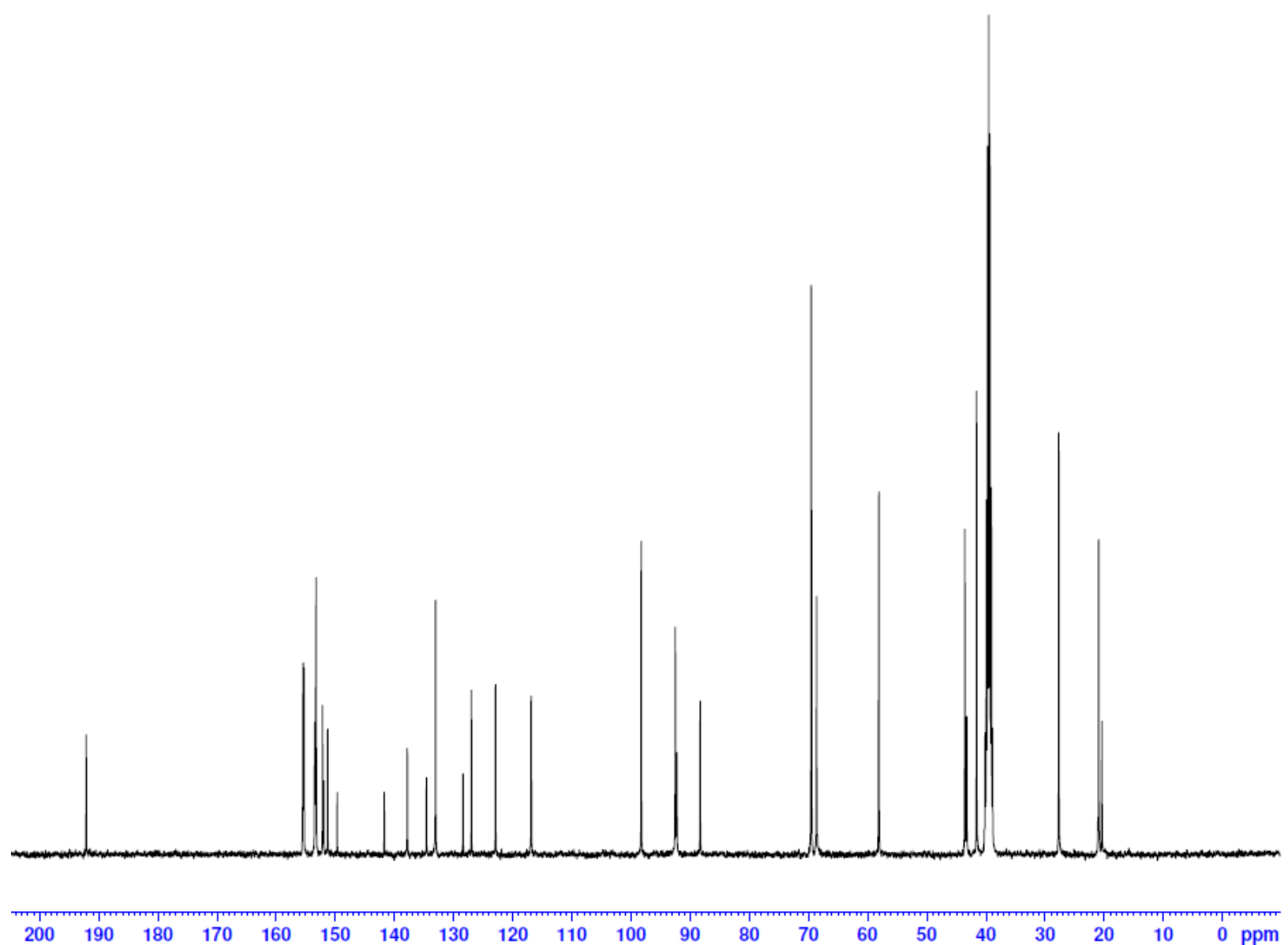

${ }^{13} \mathrm{C}$ NMR $\left(101 \mathrm{MHz}, \mathrm{DMSO}-d_{6}\right) \delta 192.10,155.48,155.43,155.30,153.45,153.35,153.25,152.15,151.95,151.31$, 149.66, 141.71, 137.82, 134.58, 133.06, 128.37, 126.99, 122.92, 116.89, 98.26, 92.51, 92.23, 88.30, 69.51, 68.58, $58.15,58.08,43.53,43.26,41.55,27.67,20.94,20.35$. 


\section{LC/MS (Method C) 43}

UV Detector: TAC: Wavelength Range: $(210-450)$

8. $709 e+1$

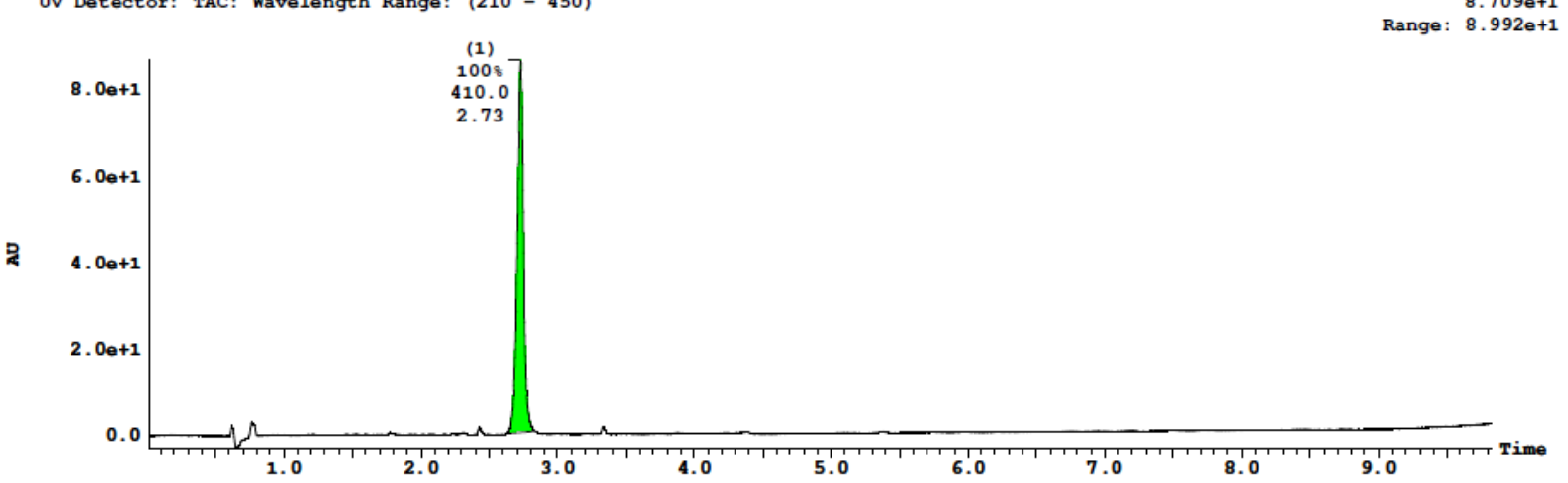

(Time: 2.73) Center (Cen, 4, 80.00, Ar); Combine $(605: 610)$

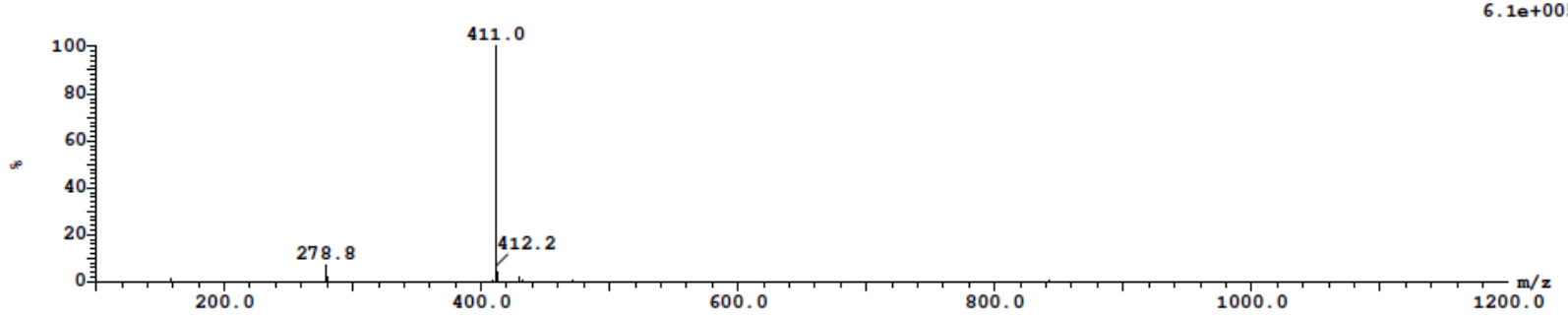


$400 \mathrm{MHz}^{1} \mathrm{H}$ NMR in DMSO- $d_{6}$ of $N$-(5-cyano-4-(2-methoxyethoxy)pyridin-2-yl)-7-formyl-6-methoxy-3,4dihydro-1,8-naphthyridine-1 $(2 H)$-carboxamide 44

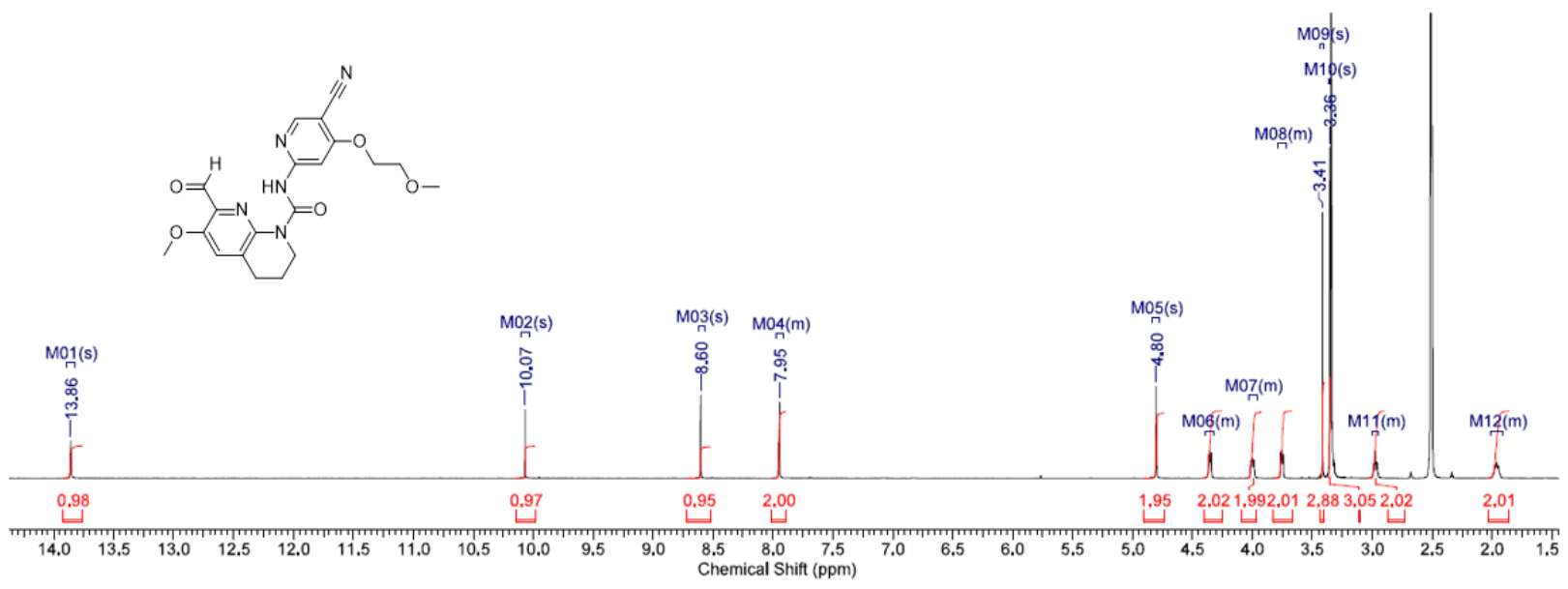

$400 \mathrm{MHz}{ }^{1} \mathrm{H}$ NMR in DMSO- $d_{6}$ of $N$-(5-cyano-4-(2-methoxyethoxy)pyridin-2-yl)-6-(difluoromethyl)-7-formyl-3,4dihydro-1,8-naphthyridine-1 $(2 H)$-carboxamide 45

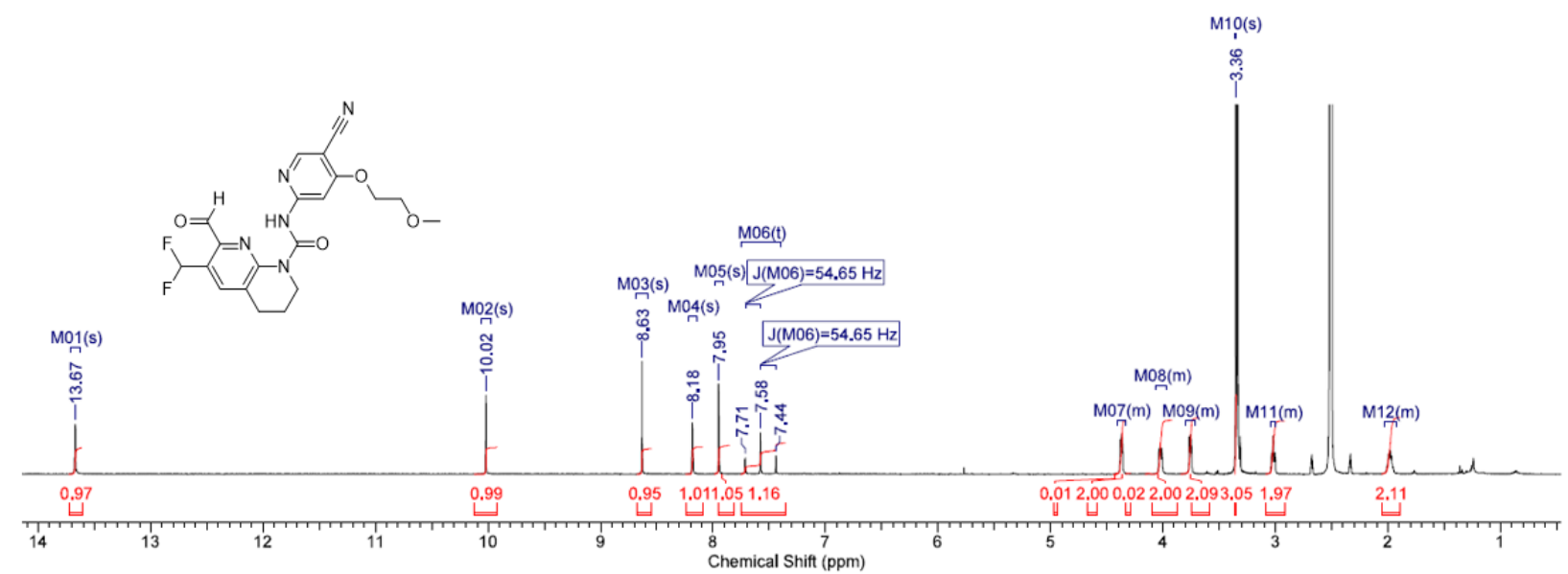


$600 \mathrm{MHz}{ }^{1} \mathrm{H},{ }^{13} \mathrm{C}$ HSQC NMR in DMSO- $d_{6}$ of $N$-(5-cyano-4-((2-methoxyethyl)amino)pyridin-2-yl)-6(difluoromethyl)-7-formyl-3,4-dihydro-1,8-naphthyridine-1(2H)-carboxamide 46

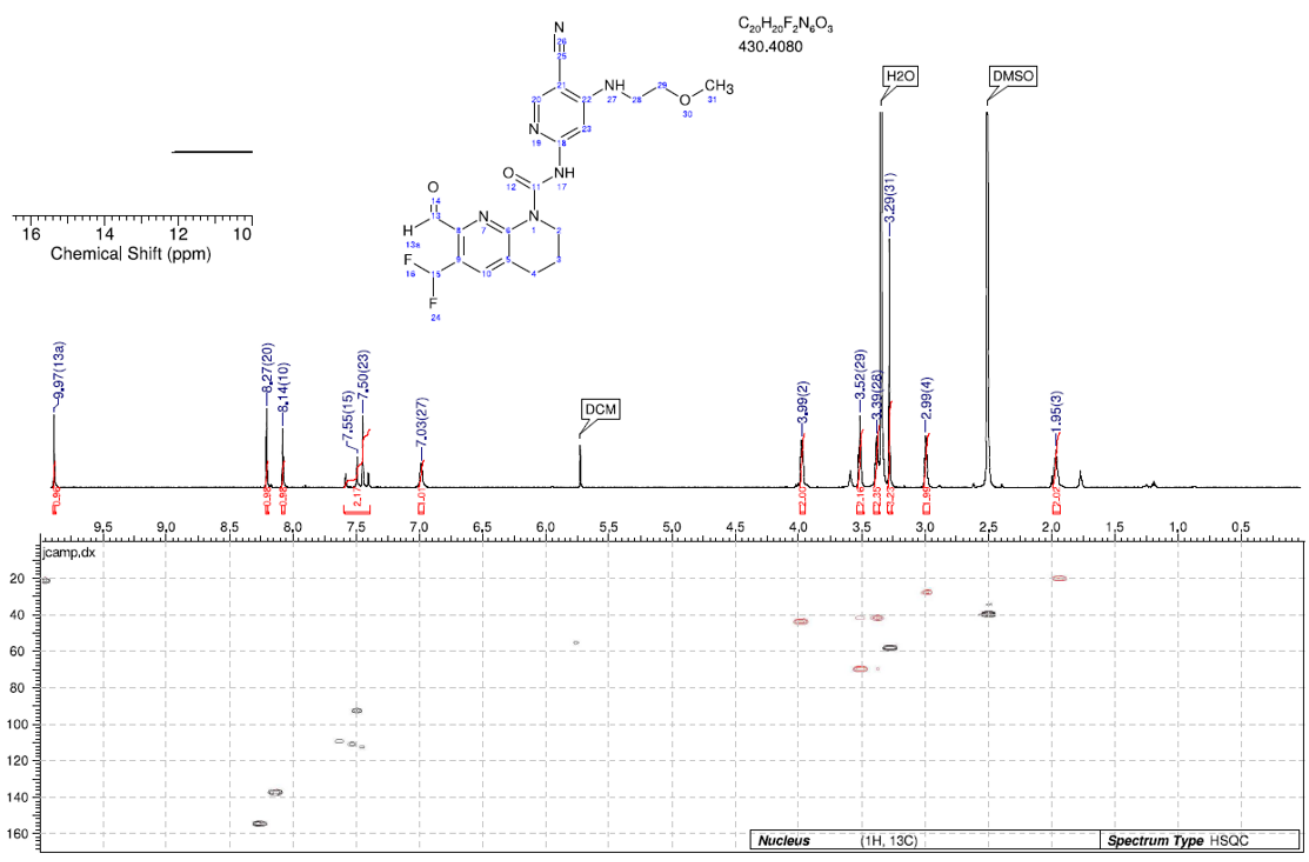

$400 \mathrm{MHz}{ }^{1} \mathrm{H}$ NMR in DMSO- $d_{6}$ of $N$-(5-cyano-4-(2-methoxyethoxy)pyridin-2-yl)-7-formyl-6-(trifluoromethyl)-3,4dihydro-1,8-naphthyridine-1(2H)-carboxamide 47 (obtained as a 3:1 mixture of the hydrate and aldehyde)
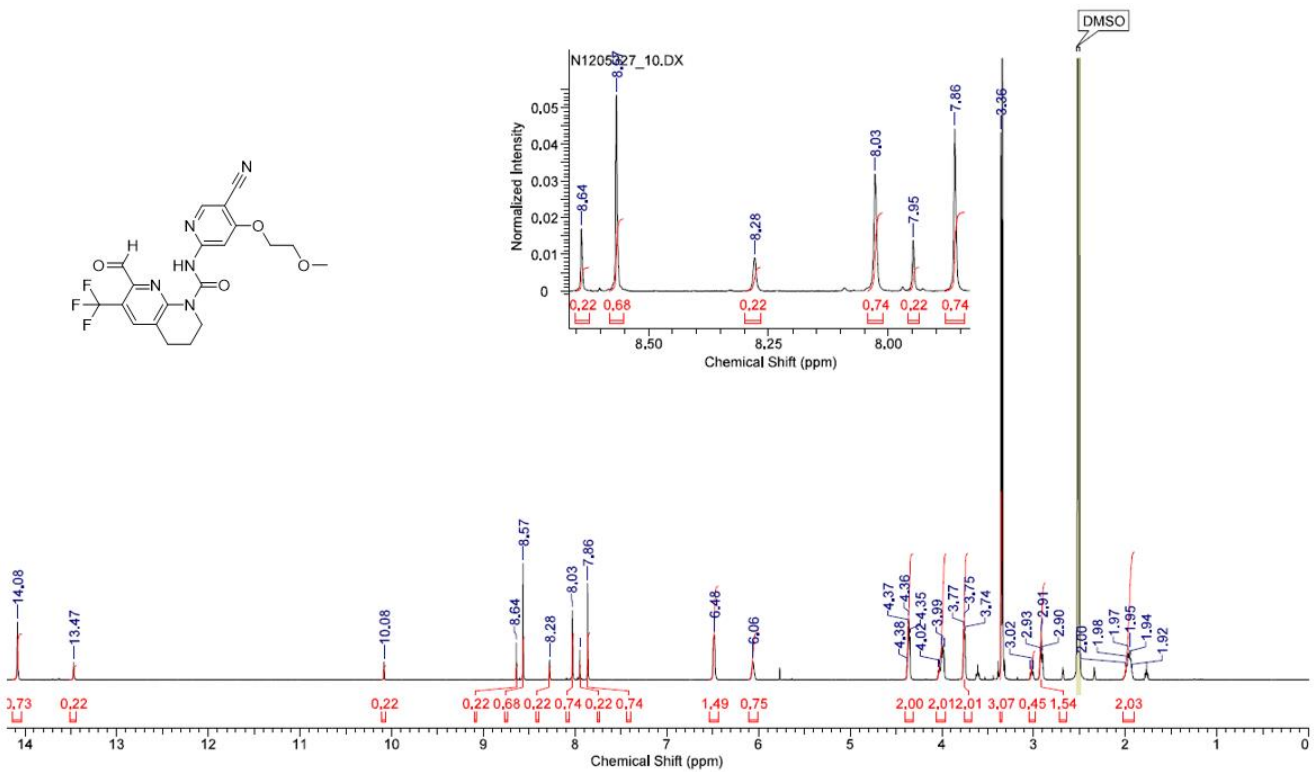
$400 \mathrm{MHz}{ }^{1} \mathrm{H},{ }^{13} \mathrm{C}$ HSQC NMR in DMSO- $d_{6}$ of $N$-(5-cyano-4-((2-methoxyethyl)amino)pyridin-2-yl)-7-formyl-6-(2methylthiazol-5-yl)-3,4-dihydro-1,8-naphthyridine-1 $(2 H)$-carboxamide $\mathbf{4 8}$ (obtained as a 2:1 mixture of the hydrate and aldehyde)
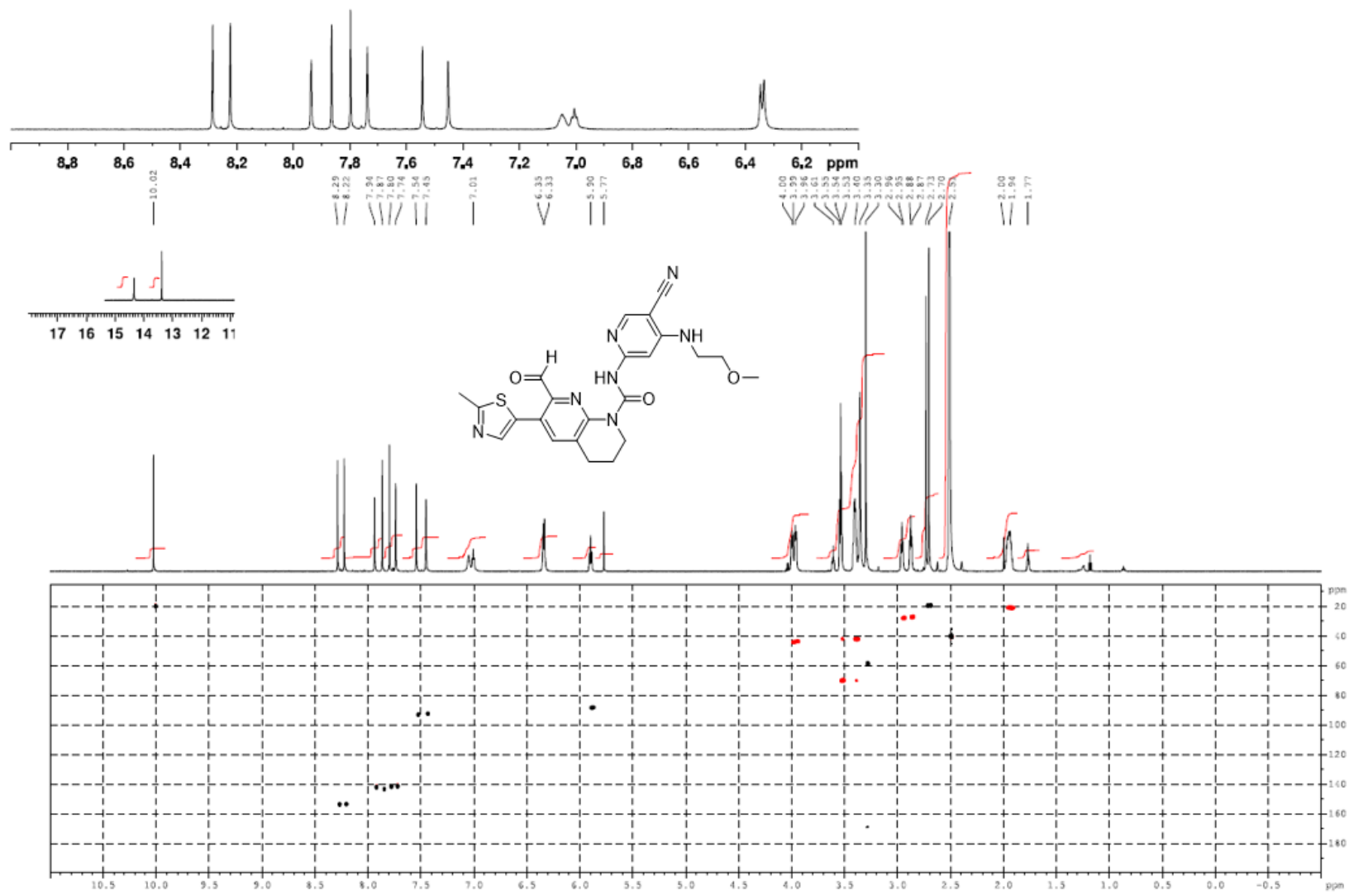
$600 \mathrm{MHz}{ }^{1} \mathrm{H}$ NMR in chloroform- $d_{1}$ of $N$-(5-cyano-4-((2-methoxyethyl)amino)pyridin-2-yl)-7-formyl-6-(1-methyl1H-pyrazol-5-yl)-3,4-dihydro-1,8-naphthyridine-1 $(2 H)$-carboxamide 49

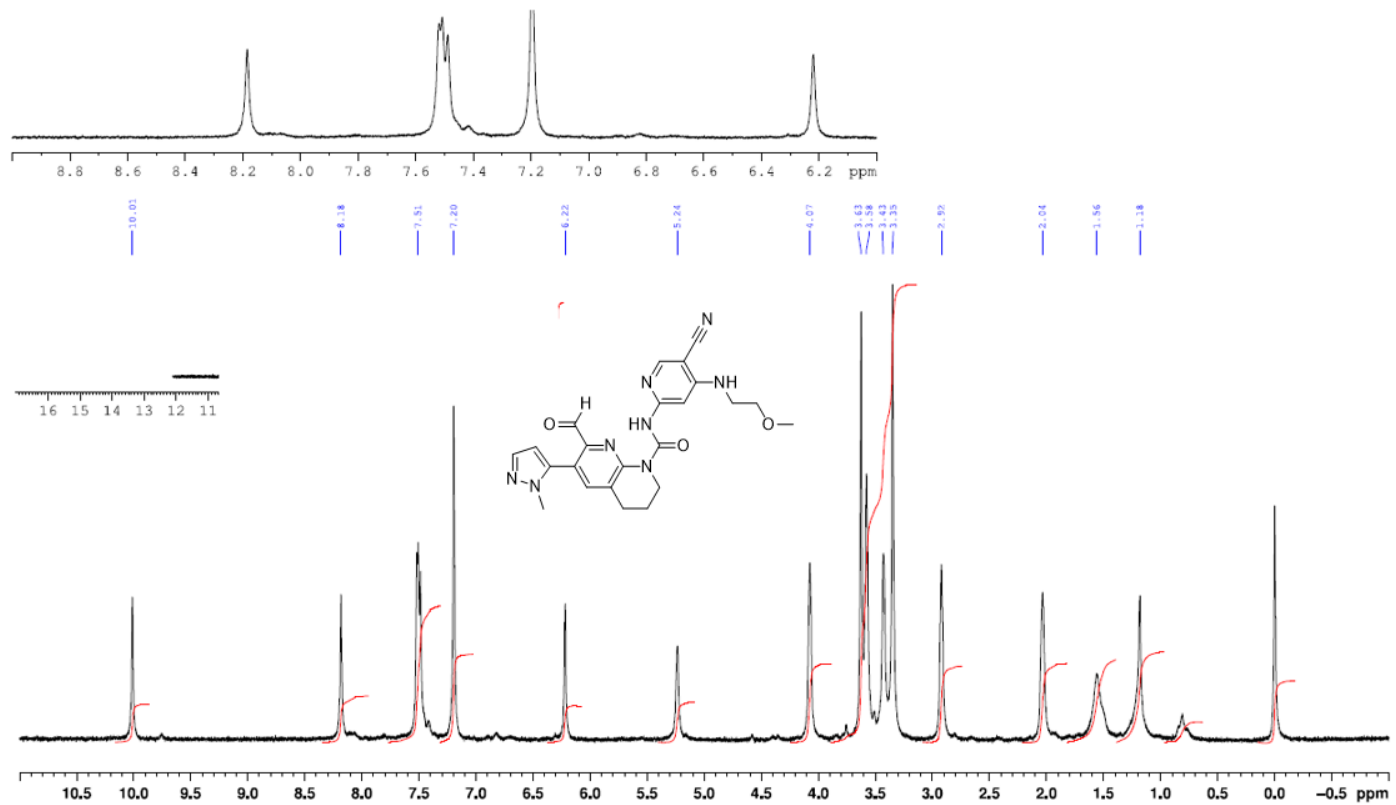

$600 \mathrm{MHz}{ }^{1} \mathrm{H}$ NMR in chloroform- $d_{1}$ of $N$-(5-cyano-4-((2-methoxyethyl)amino)pyridin-2-yl)-7-formyl-6-(pyridin-3yl)-3,4-dihydro-1,8-naphthyridine-1 $(2 H)$-carboxamide $\mathbf{5 0}$
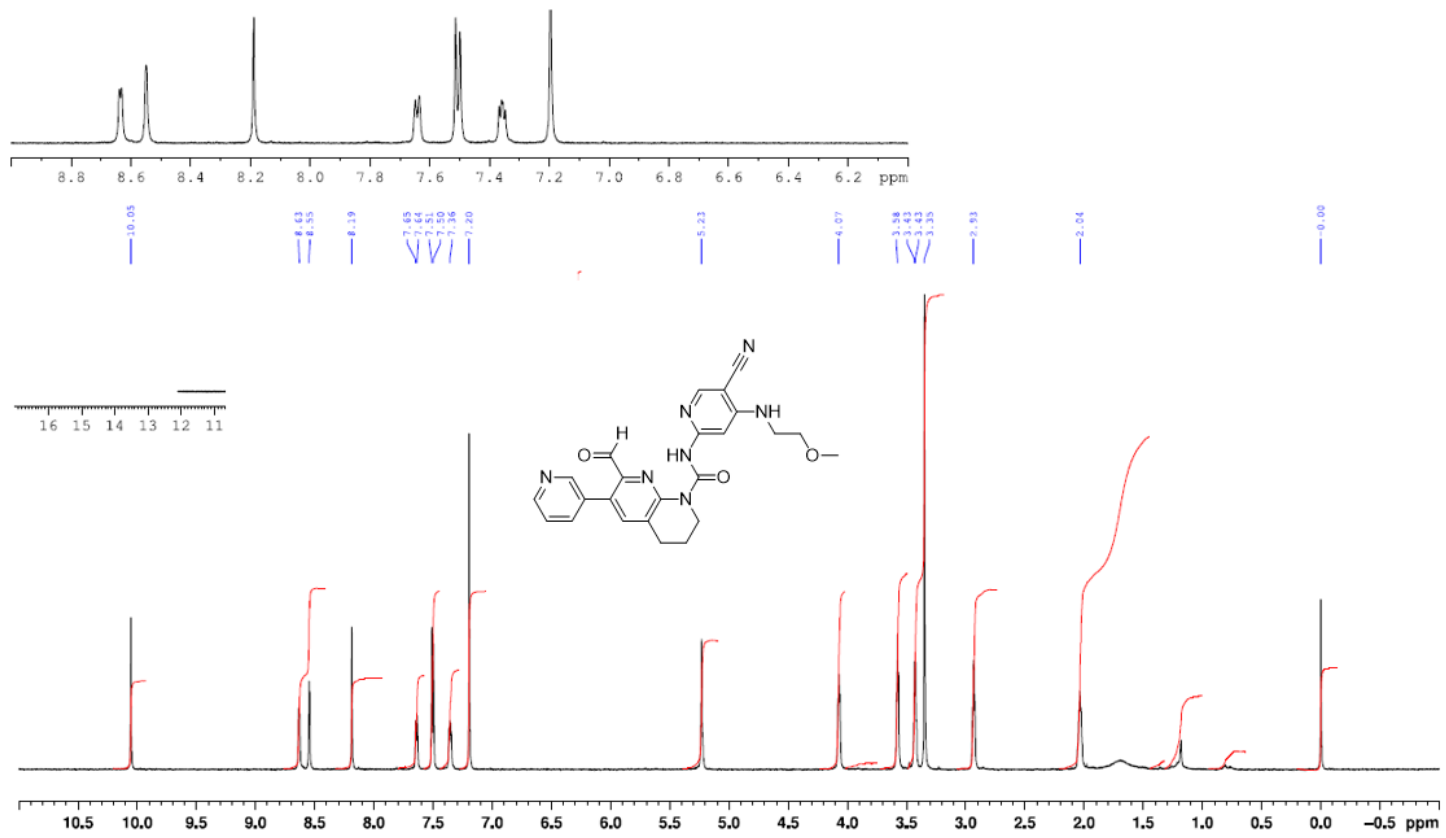
$400 \mathrm{MHz}{ }^{1} \mathrm{H}$ NMR in chloroform- $d_{1}$ of $N$-(5-cyano-4-((2-methoxyethyl)amino)pyridin-2-yl)-7-formyl-6-(4-methyl1H-imidazol-1-yl)-3,4-dihydro-1,8-naphthyridine-1 $(2 H)$-carboxamide $\mathbf{5 1}$

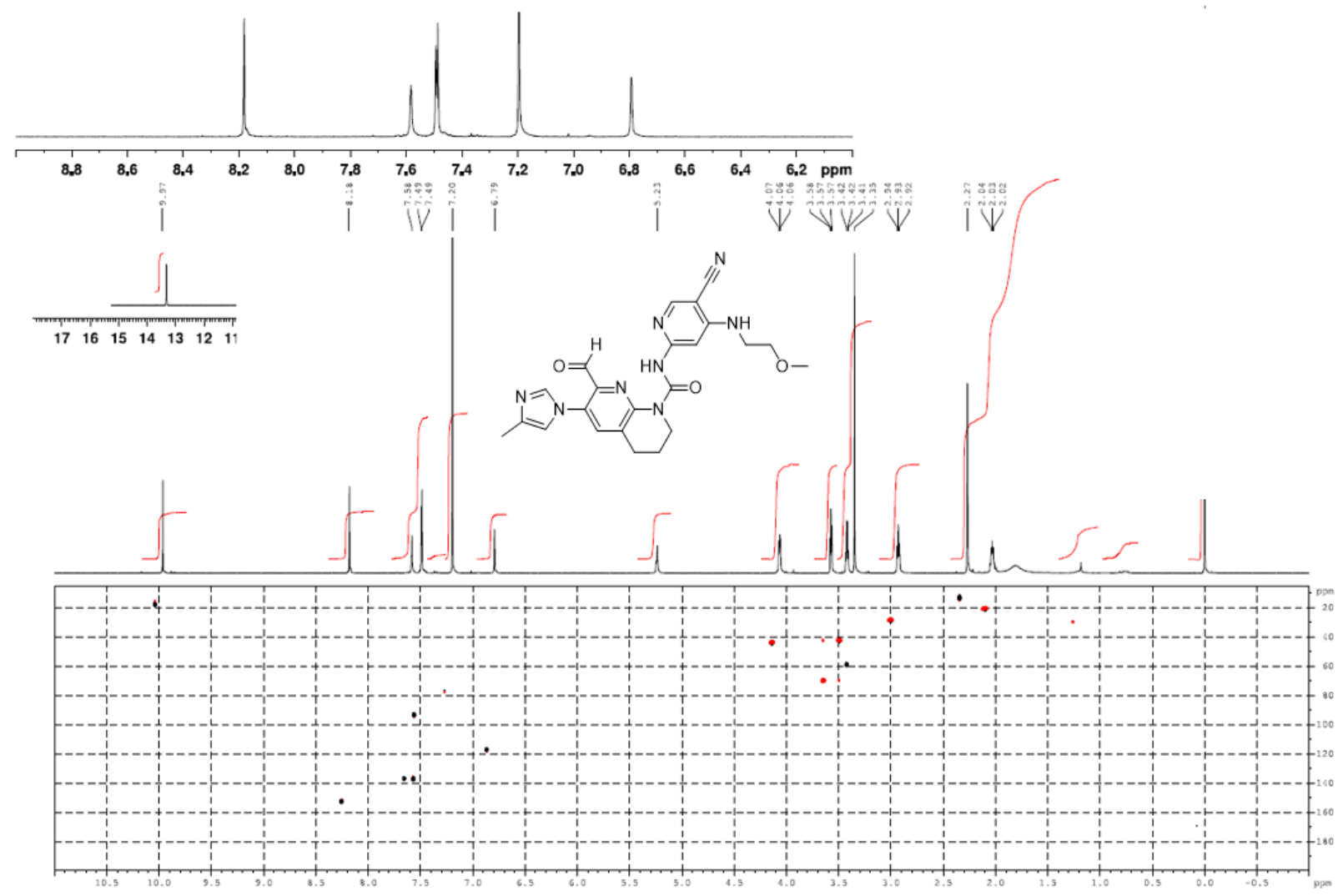


$400 \mathrm{MHz}{ }^{1} \mathrm{H}$ NMR in DMSO- $d_{6}$ of $N$-(5-cyano-4-((2-methoxyethyl)amino)pyridin-2-yl)-7-formyl-6-(tetrahydro- $2 \mathrm{H}-$ pyran-4-yl)-3,4-dihydro-1,8-naphthyridine-1 $(2 H)$-carboxamide $\mathbf{5 2}$

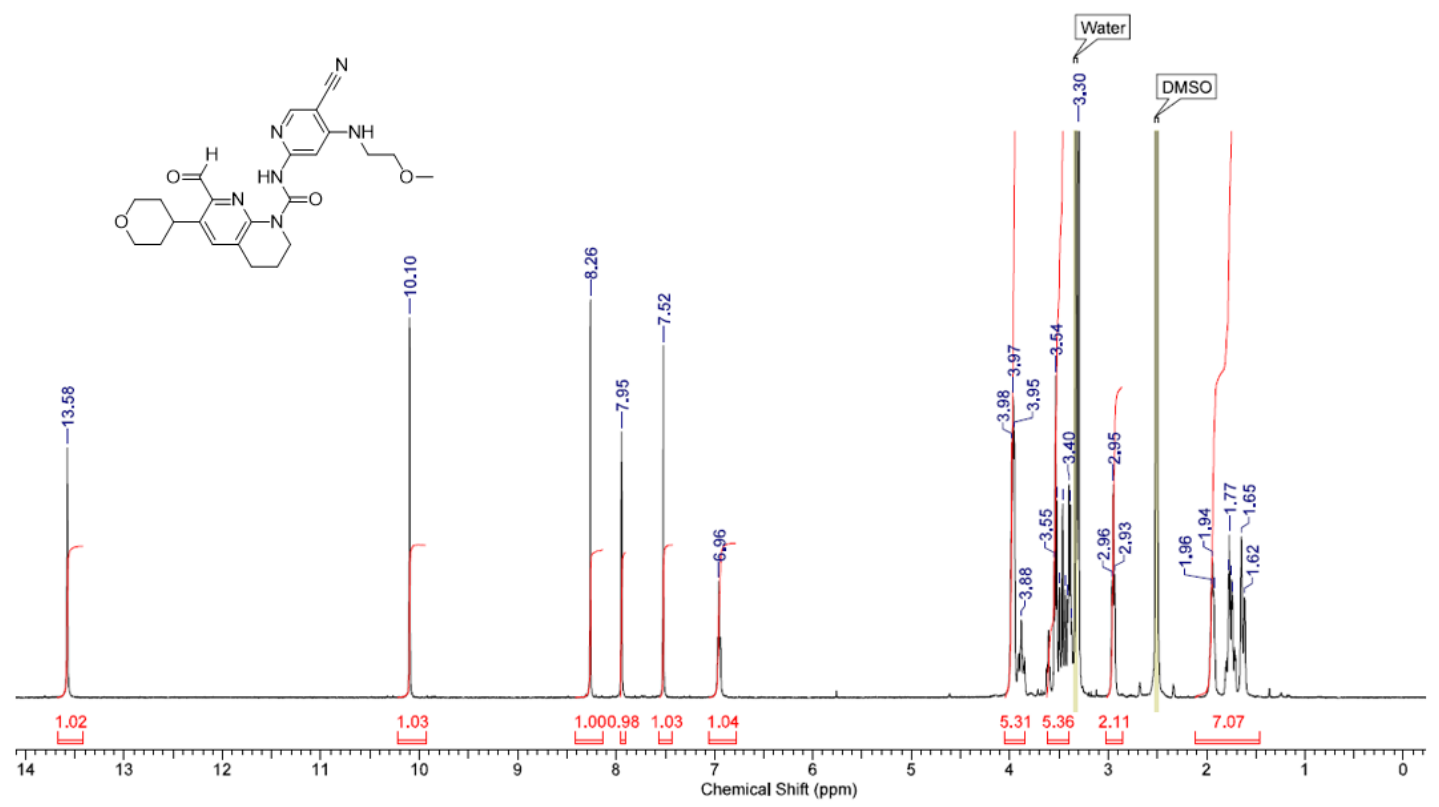

$400 \mathrm{MHz}{ }^{1} \mathrm{H}$ NMR in DMSO- 66 of $N$-(5-cyano-4-((2-methoxyethyl)amino)pyridin-2-yl)-7-formyl-6-(1-(oxetan-3yl)piperidin-4-yl)-3,4-dihydro-1,8-naphthyridine-1(2H)-carboxamide $\mathbf{5 3}$

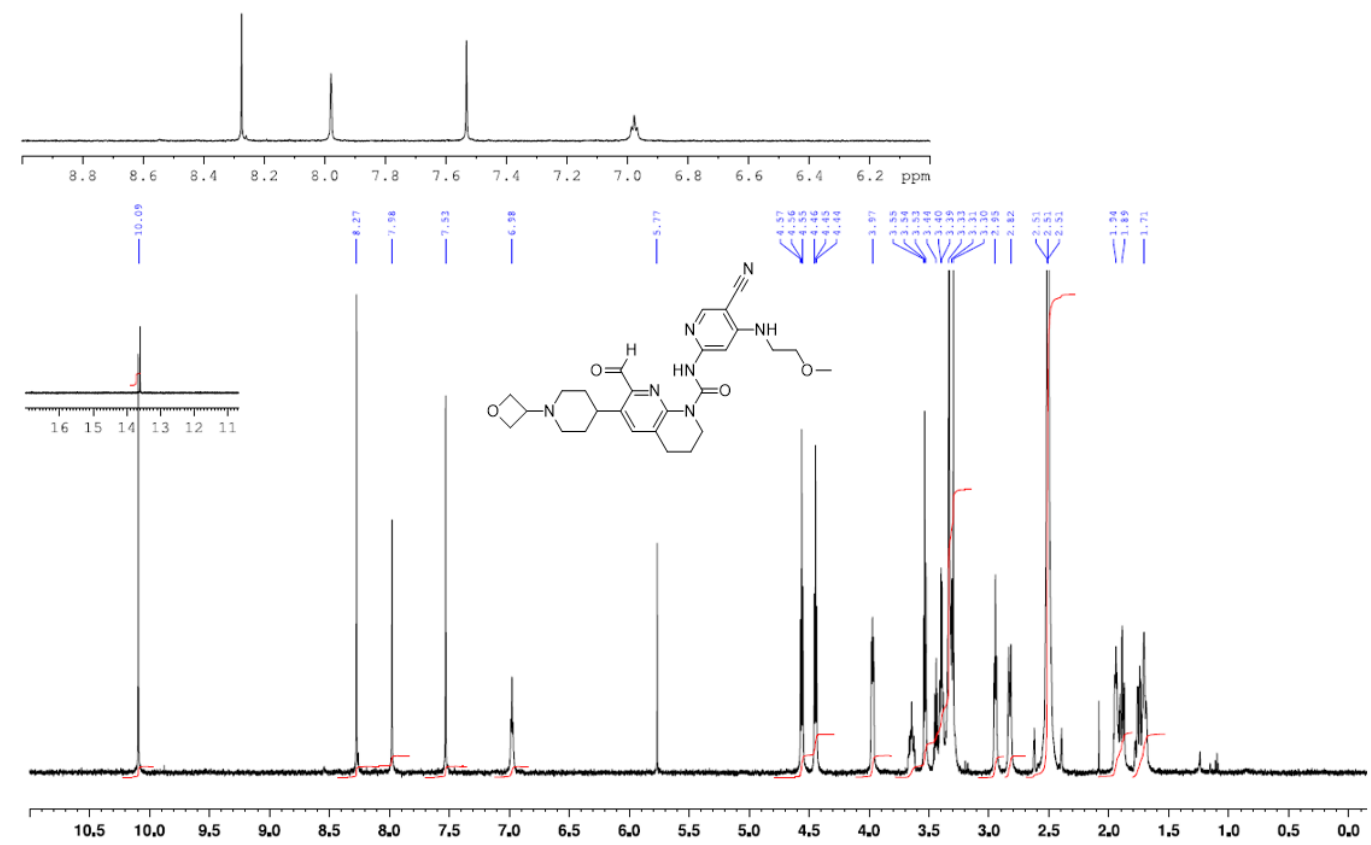


$400 \mathrm{MHz}{ }^{1} \mathrm{H},{ }^{13} \mathrm{C}$ HSQC NMR in DMSO- $d_{6}$ of $N$-(5-cyano-4-((2-methoxyethyl)amino)pyridin-2-yl)-7-formyl-6-(2oxopiperidin-1-yl)-3,4-dihydro-1,8-naphthyridine-1(2H)-carboxamide $\mathbf{5 4}$

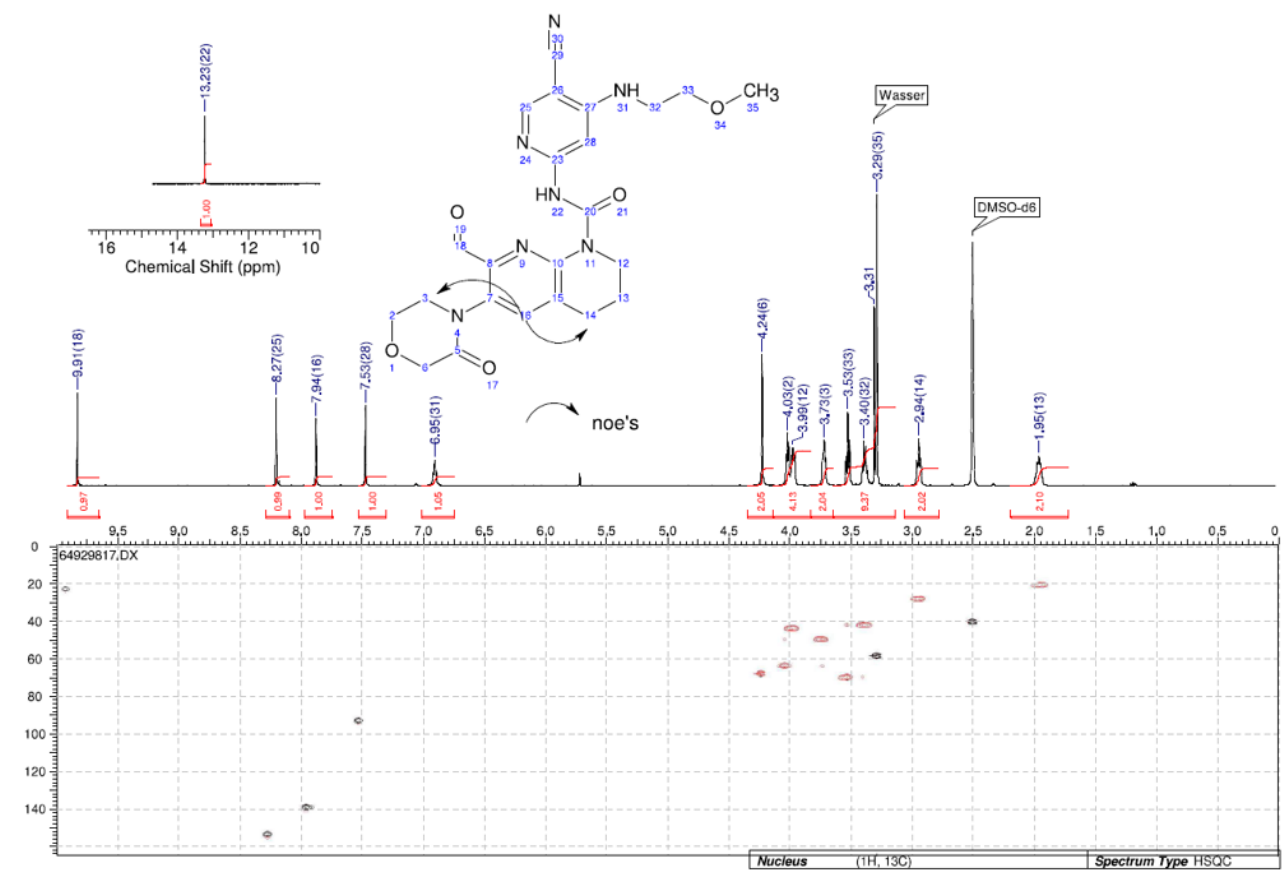

$400 \mathrm{MHz}{ }^{1} \mathrm{H}$ NMR in DMSO- $d_{6}$ of $(R)$ - and $(S)-N$-(5-cyano-4-((tetrahydrofuran-3-yl)oxy)pyridin-2-yl)-7-formyl-6(hydroxymethyl)-3,4-dihydro-1,8-naphthyridine-1 $(2 H)$-carboxamide 57 and $\mathbf{5 8}$

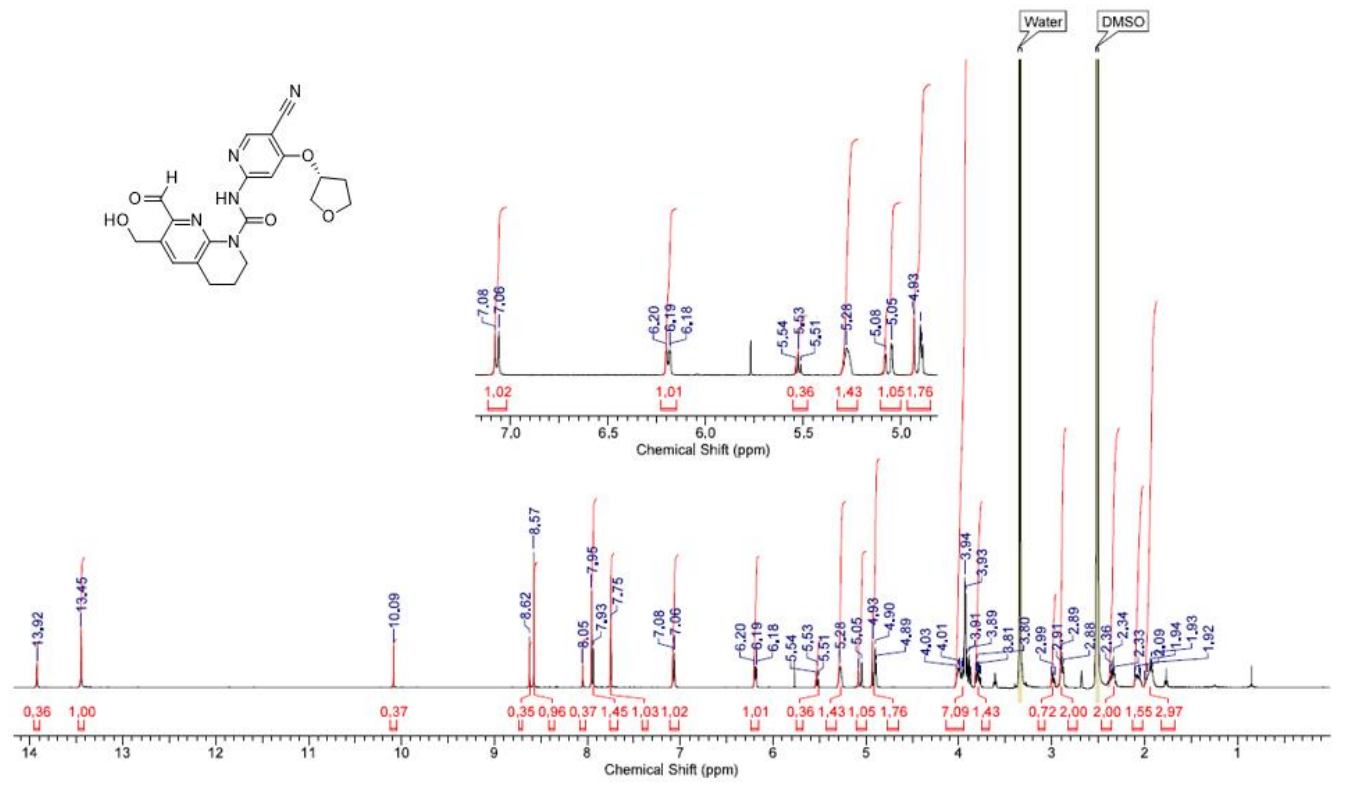


Figure 17 and Table 7

\begin{tabular}{|c|c|c|}
\hline Compound & Analytical data & Synthesis method ${ }^{\mathrm{S} 11}$ \\
\hline 59 & $\begin{array}{l}\text { White solid. LC/MS (Method A): tR } 0.91 \mathrm{~min}, \mathrm{~m} / z 393.2(100 \% \text {, } \\
\qquad \mathrm{M}+\mathrm{H}), 391.3(100 \%, \mathrm{M}-\mathrm{H}) .\end{array}$ & Aza anion urea formation \\
\hline 60 & $\begin{array}{l}\text { Pale-pink solid. LC/MS (Method A): tR } 1.00 \mathrm{~min}, m / z 450.3(100 \% \text {, } \\
\qquad \mathrm{M}+\mathrm{H}), 448.3(20 \%, \mathrm{M}-\mathrm{H}) .\end{array}$ & $\begin{array}{l}\text { Aza anion urea formation } \\
\text { with } 2.0 \text { equiv. LiHMDS }\end{array}$ \\
\hline 61 & $\begin{array}{c}\text { White crystalline solid, mp } 201{ }^{\circ} \mathrm{C}(\mathrm{DSC}) . \mathrm{LC} / \mathrm{MS}(\text { Method } \mathrm{A}): \mathrm{t}_{\mathrm{R}} \\
0.88, \mathrm{~m} / z 466.3(100 \%, \mathrm{M}+\mathrm{H}), 217.0(100 \%, \text { pyridineNCO-H), } \\
464.2(60 \%, \mathrm{M}-\mathrm{H}) .\end{array}$ & $\begin{array}{l}\text { Aza anion urea formation } \\
\text { with } 2.0 \text { equiv. LiHMDS }\end{array}$ \\
\hline 62 & $\begin{array}{l}\text { White crystalline solid. LC/MS (Method A): } \mathrm{t}_{\mathrm{R}} 0.93 \mathrm{~min}, \mathrm{~m} / \mathrm{z}, 467.2 \\
\qquad(100 \%, \mathrm{M}+\mathrm{H}), 465.1(100 \%, \mathrm{M}-\mathrm{H})\end{array}$ & Aza anion urea formation \\
\hline 63 & $\begin{array}{l}\text { White solid. LC/MS (Method A): tR } 1.04 \mathrm{~min}, \mathrm{~m} / z 494.3(100 \%, \\
\mathrm{M}+\mathrm{H}), 217.1(100 \% \text {, pyridineNCO-H), } 492.3(25 \%, \mathrm{M}-\mathrm{H}) .\end{array}$ & $\begin{array}{l}\text { Aza anion urea formation } \\
\text { with } 2.2 \text { equiv. LiHMDS }\end{array}$ \\
\hline 64 & $\begin{array}{l}\text { White crystalline solid. LC/MS (Method A): to } 0.89 \mathrm{~min}, \mathrm{~m} / z 496.3 \\
(100 \%, \mathrm{M}+\mathrm{H}), 217.1(100 \% \text {, pyridineNCO-H), } 494.3(10 \%, \mathrm{M}-\mathrm{H}) \text {. }\end{array}$ & $\begin{array}{l}\text { Aza anion urea formation } \\
\text { with } 2.2 \text { equiv. LiHMDS }\end{array}$ \\
\hline 65 & $\begin{array}{l}\text { White crystalline solid. LC/MS (Method A): } \mathrm{t}_{\mathrm{R}} 0.95 \mathrm{~min}, \mathrm{~m} / \mathrm{z} 480.4 \\
(100 \%, \mathrm{M}+\mathrm{H}), 217.2(100 \% \text {, pyridineNCO-H), } 478.6(10 \%, \mathrm{M}-\mathrm{H}) \text {. }\end{array}$ & $\begin{array}{l}\text { Aza anion urea formation } \\
\text { with } 2.2 \text { equiv. LiHMDS }\end{array}$ \\
\hline 66 & $\begin{array}{l}\text { Pale-pink solid. LC/MS (Method A): } \mathrm{t}_{\mathrm{R}} 1.18 \mathrm{~min}, \mathrm{~m} / z 479.3(100 \% \text {, } \\
\qquad \mathrm{M}+\mathrm{H}), 477.3(100 \%, \mathrm{M}-\mathrm{H}) .\end{array}$ & $\begin{array}{l}\text { Aza anion urea formation } \\
\text { with } 2.2 \text { equiv. LiHMDS }\end{array}$ \\
\hline 67 & $\begin{array}{l}\text { Pale-yellow solid. LC/MS (Method A): } \mathrm{t}_{\mathrm{R}} 1.13 \mathrm{~min}, \mathrm{~m} / z 487.2 \\
\qquad(100 \%, \mathrm{M}+\mathrm{H}), 485.1(100 \%, \mathrm{M}-\mathrm{H}) .\end{array}$ & $\begin{array}{l}\text { Aza anion urea formation } \\
\text { with } 2.2 \text { equiv. LiHMDS }\end{array}$ \\
\hline 69 & $\begin{array}{l}\text { Beige solid. LC/MS (Method A): tr } 0.88 \mathrm{~min}, \mathrm{~m} / \mathrm{z} 494.2(100 \% \text {, } \\
\qquad \mathrm{M}+\mathrm{H}), 409.2(100 \%), 492.3(50 \%, \mathrm{M}-\mathrm{H}) .\end{array}$ & CDT urea formation \\
\hline 70 & $\begin{array}{c}\text { Pale-yellow solid. LC/MS (Method A): tR } 0.89 \text { min single peak with } \\
\text { front tail, } m / z 480.2(100 \%, \mathrm{M}+\mathrm{H}), 217.0(100 \% \text {, pyridineNCO-H), } \\
478.1(40 \%, \mathrm{M}-\mathrm{H}) .\end{array}$ & CDT urea formation \\
\hline
\end{tabular}

Table S2 Analytical data and the urea bond forming approach used to prepare the compounds included in Figure 17 of the main text. 
$400 \mathrm{MHz}{ }^{1} \mathrm{H}$ NMR in DMSO- $d_{6}$ of $N$-(5-cyanopyridin-2-yl)-7-formyl-6-(( $N$-methylacetamido)methyl)-3,4-dihydro1,8-naphthyridine-1 $(2 H)$-carboxamide $\mathbf{5 9}$

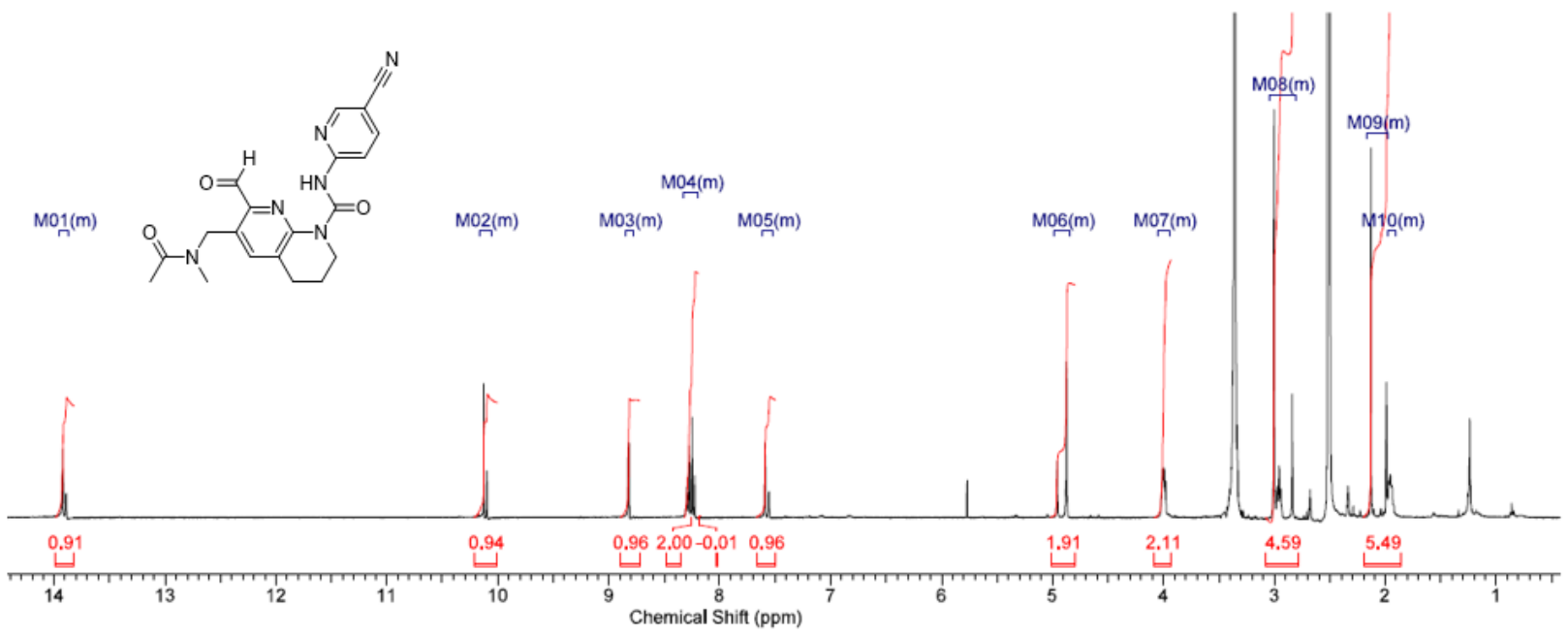

$400 \mathrm{MHz}{ }^{1} \mathrm{H},{ }^{13} \mathrm{C}$ HSQC NMR in DMSO- $d_{6}$ of $N$-(5-cyano-4-(isopropylamino)pyridin-2-yl)-7-formyl-6-(( $N$ methylacetamido)methyl)-3,4-dihydro-1,8-naphthyridine-1(2H)-carboxamide $\mathbf{6 0}$

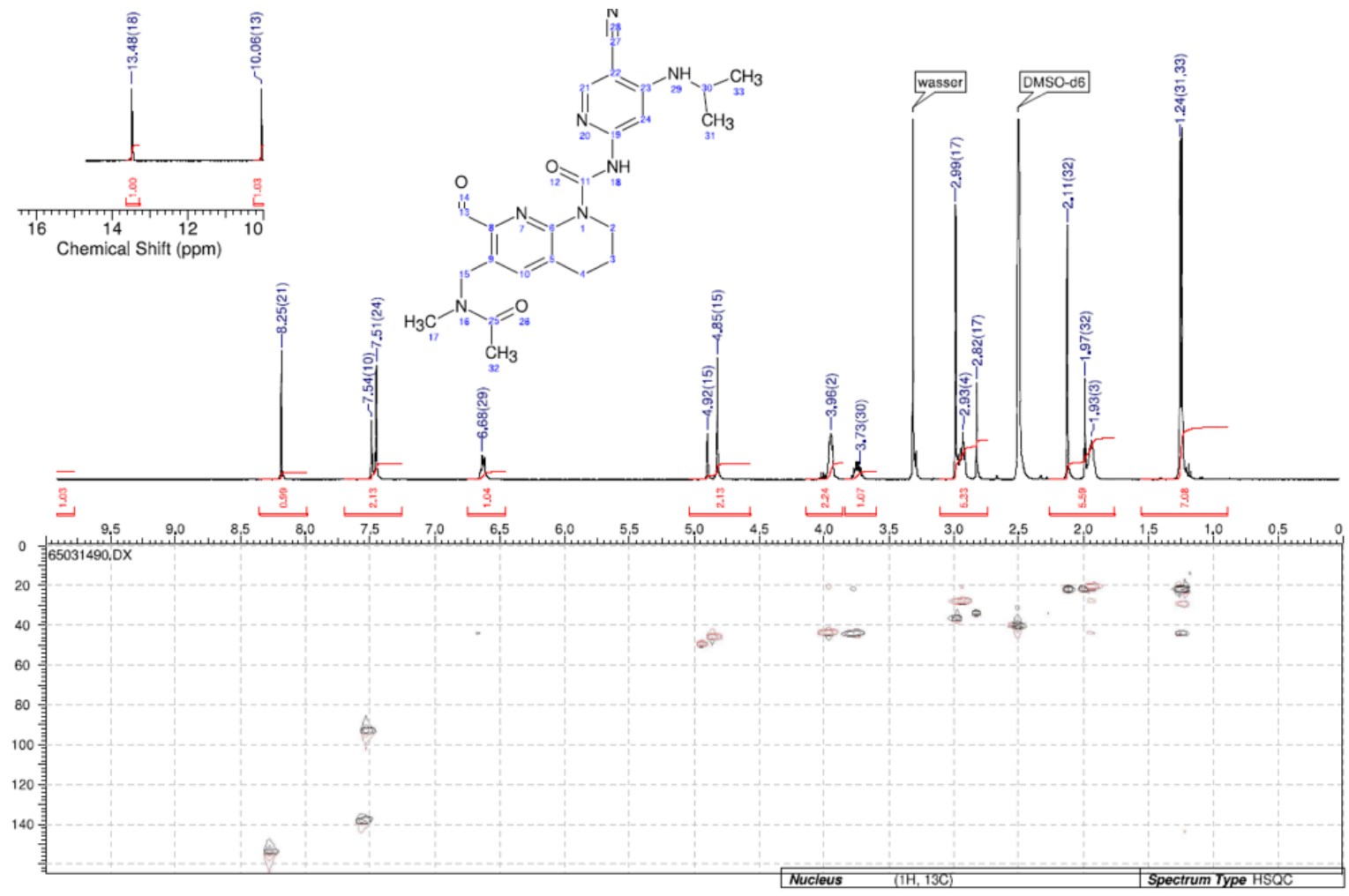


$400 \mathrm{MHz}{ }^{1} \mathrm{H},{ }^{13} \mathrm{C}$ HSQC NMR in DMSO- $d_{6}$ of $N$-(5-cyano-4-((2-methoxyethyl)amino)pyridin-2-yl)-7-formyl-6-(( $N$ methylacetamido)methyl)-3,4-dihydro-1,8-naphthyridine-1(2H)-carboxamide 61

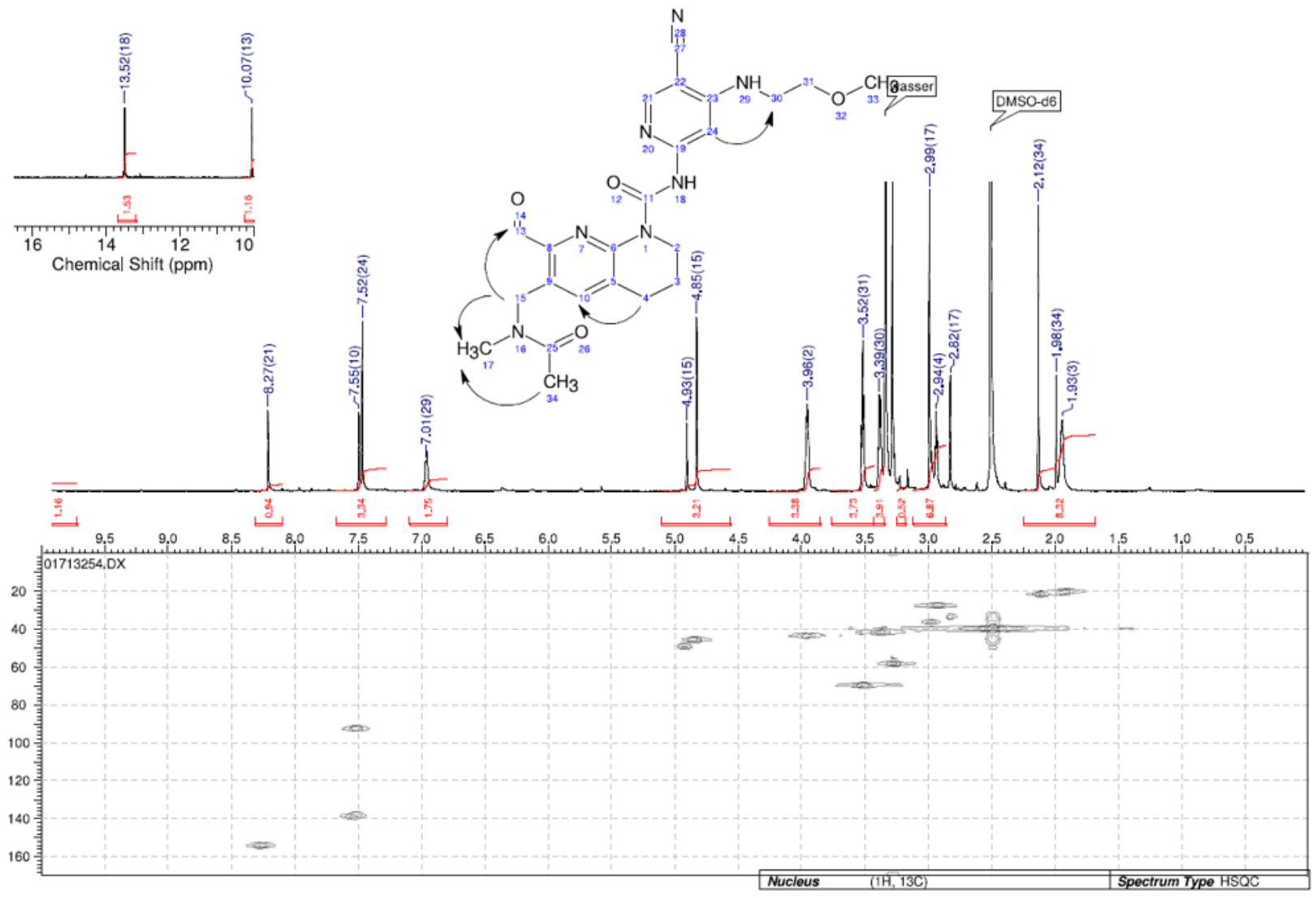


$400 \mathrm{MHz}{ }^{1} \mathrm{H}$ NMR in DMSO- $d_{6}$ of $N$-(5-cyano-4-(2-methoxyethoxy)pyridin-2-yl)-7-formyl-6-(( $N$ methylacetamido)methyl)-3,4-dihydro-1,8-naphthyridine-1(2H)-carboxamide $\mathbf{6 2}$

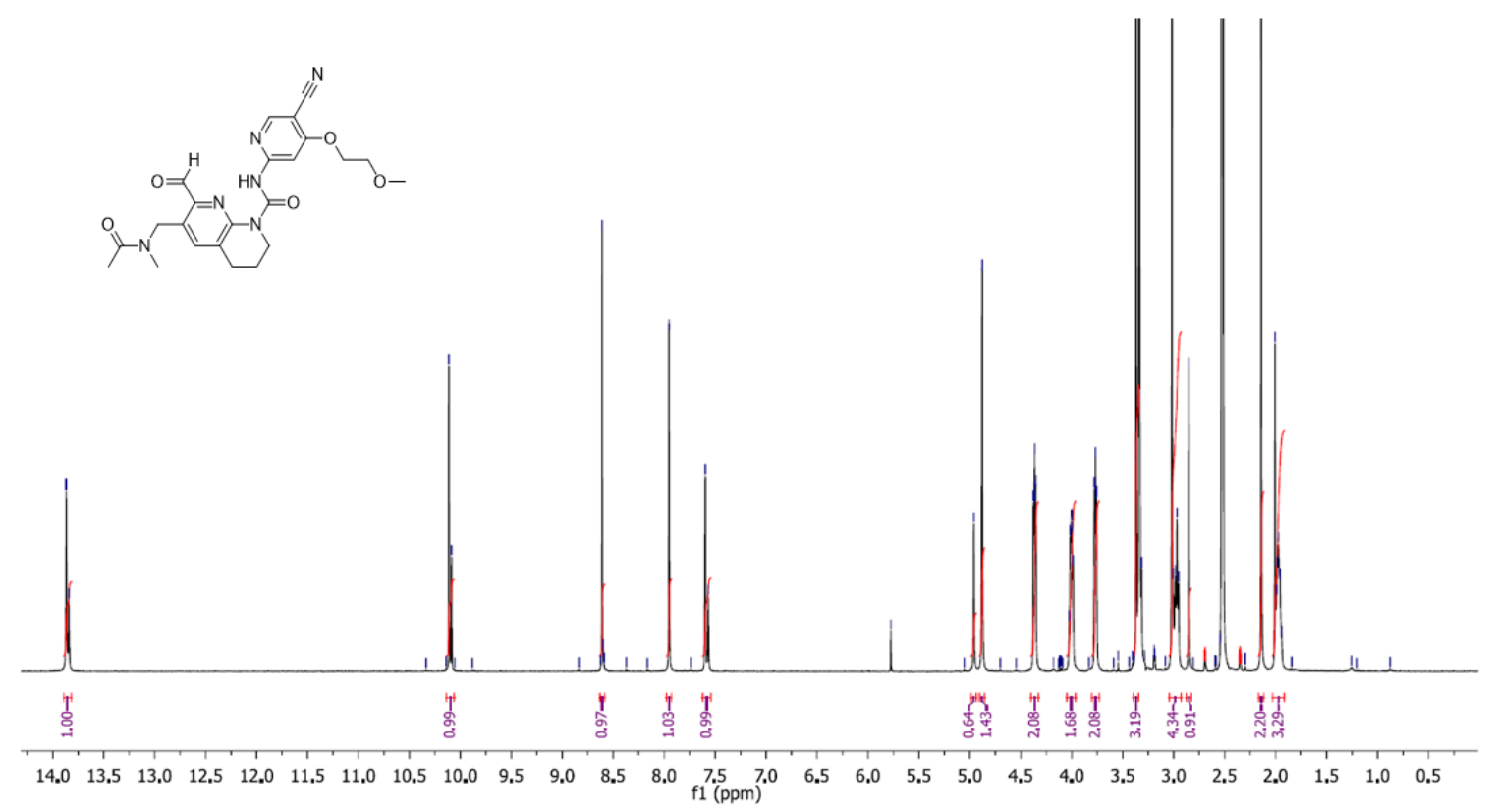

$400 \mathrm{MHz}{ }^{1} \mathrm{H}$ NMR in DMSO- $d_{6}$ of $\mathrm{N}$-(5-cyano-4-((2-methoxyethyl)amino)pyridin-2-yl)-7-formyl-6-((Nmethylisobutyramido)methyl)-3,4-dihydro-1,8-naphthyridine-1(2H)-carboxamide 63

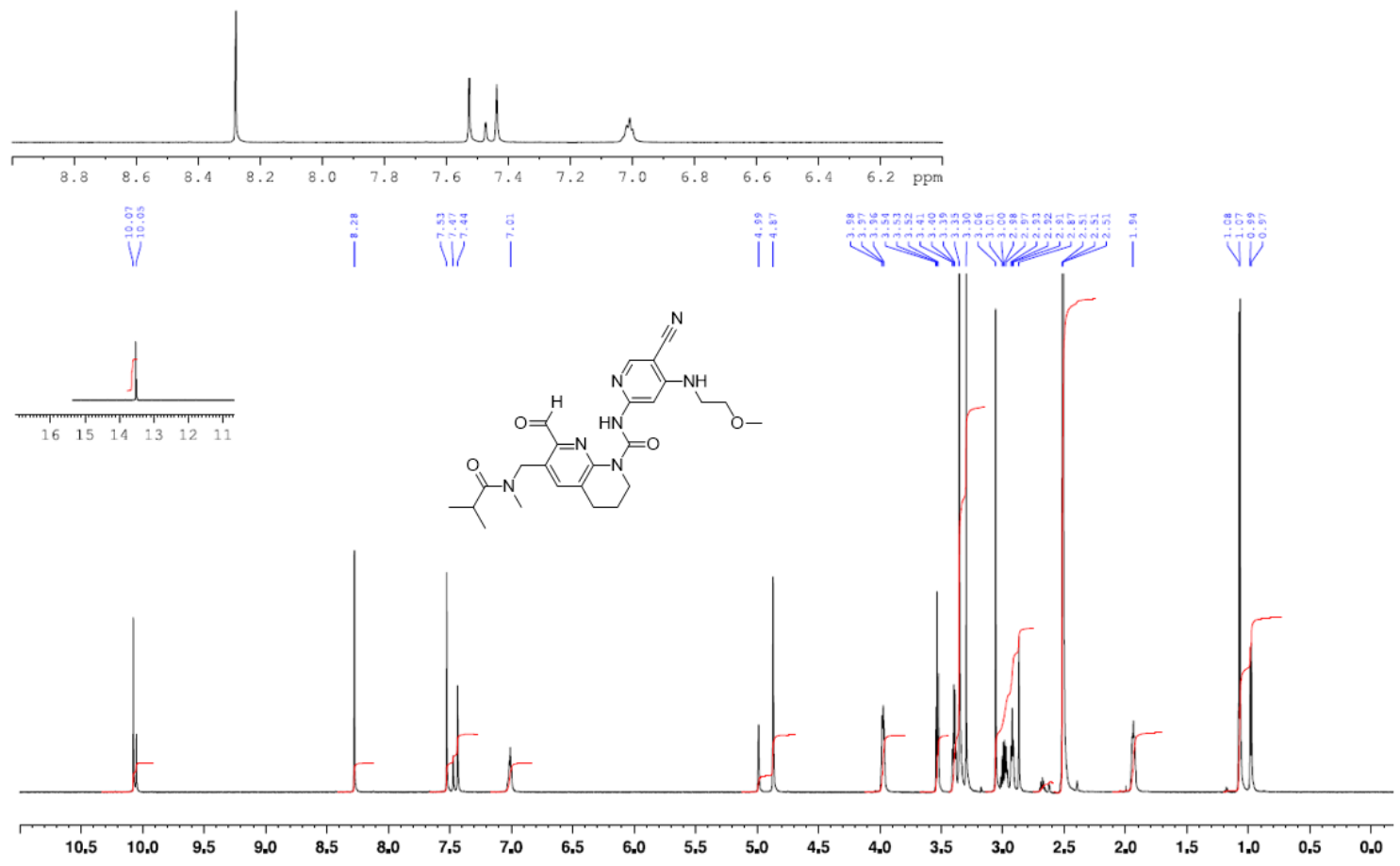


$600 \mathrm{MHz}{ }^{1} \mathrm{H},{ }^{13} \mathrm{C}$ HSQC NMR in DMSO- $d 6$ of $N$-(5-cyano-4-((2-methoxyethyl)amino)pyridin-2-yl)-7-formyl-6-((2methoxy- $N$-methylacetamido)methyl)-3,4-dihydro-1,8-naphthyridine-1(2H)-carboxamide 64
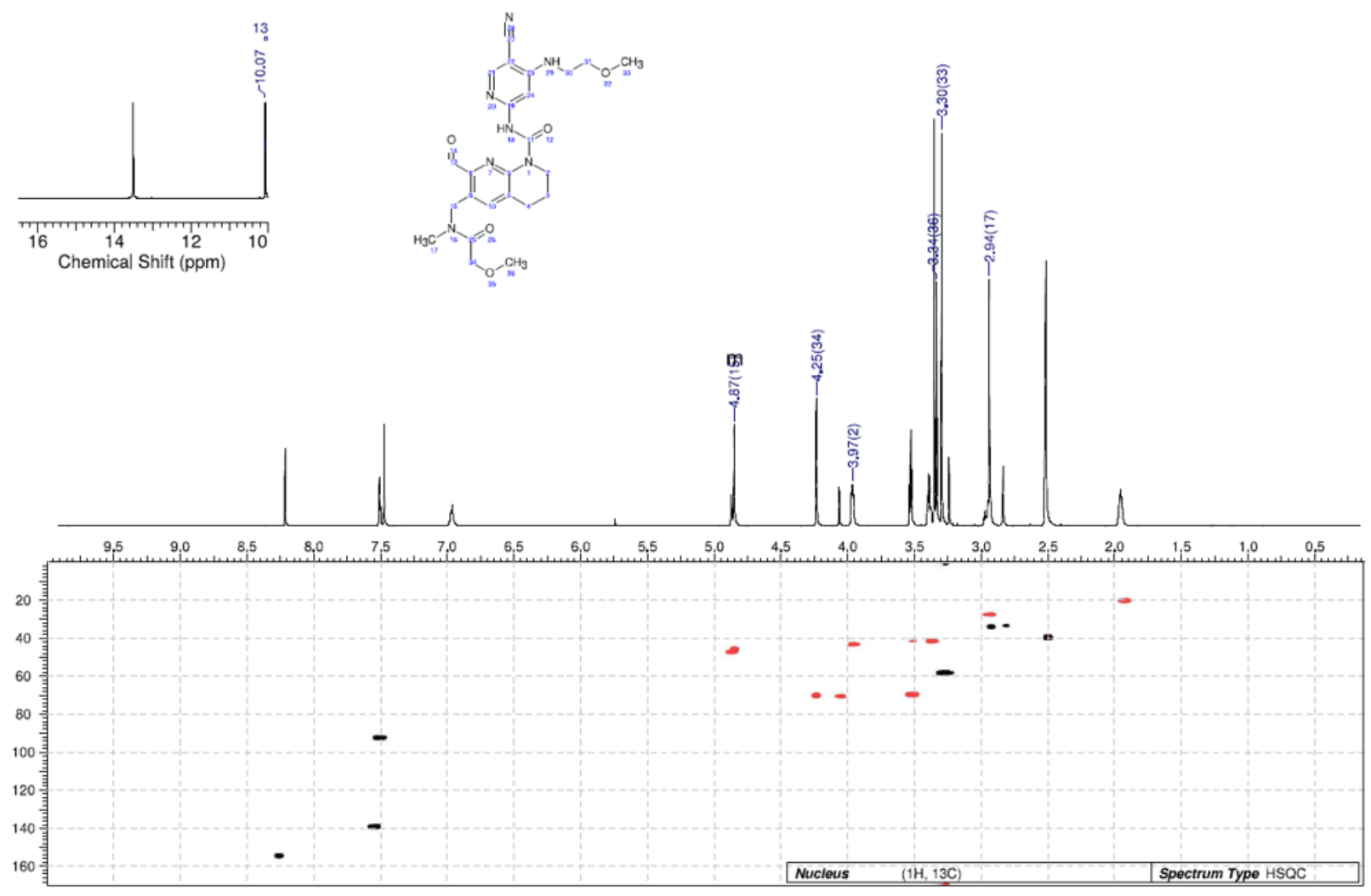
$600 \mathrm{MHz}{ }^{1} \mathrm{H},{ }^{13} \mathrm{C}$ HSQC NMR in DMSO- $d_{6}$ of $N$-(5-cyano-4-((2-methoxyethyl)amino)pyridin-2-yl)-6-(( $N$ ethylacetamido)methyl)-7-formyl-3,4-dihydro-1,8-naphthyridine-1(2H)-carboxamide $\mathbf{6 5}$
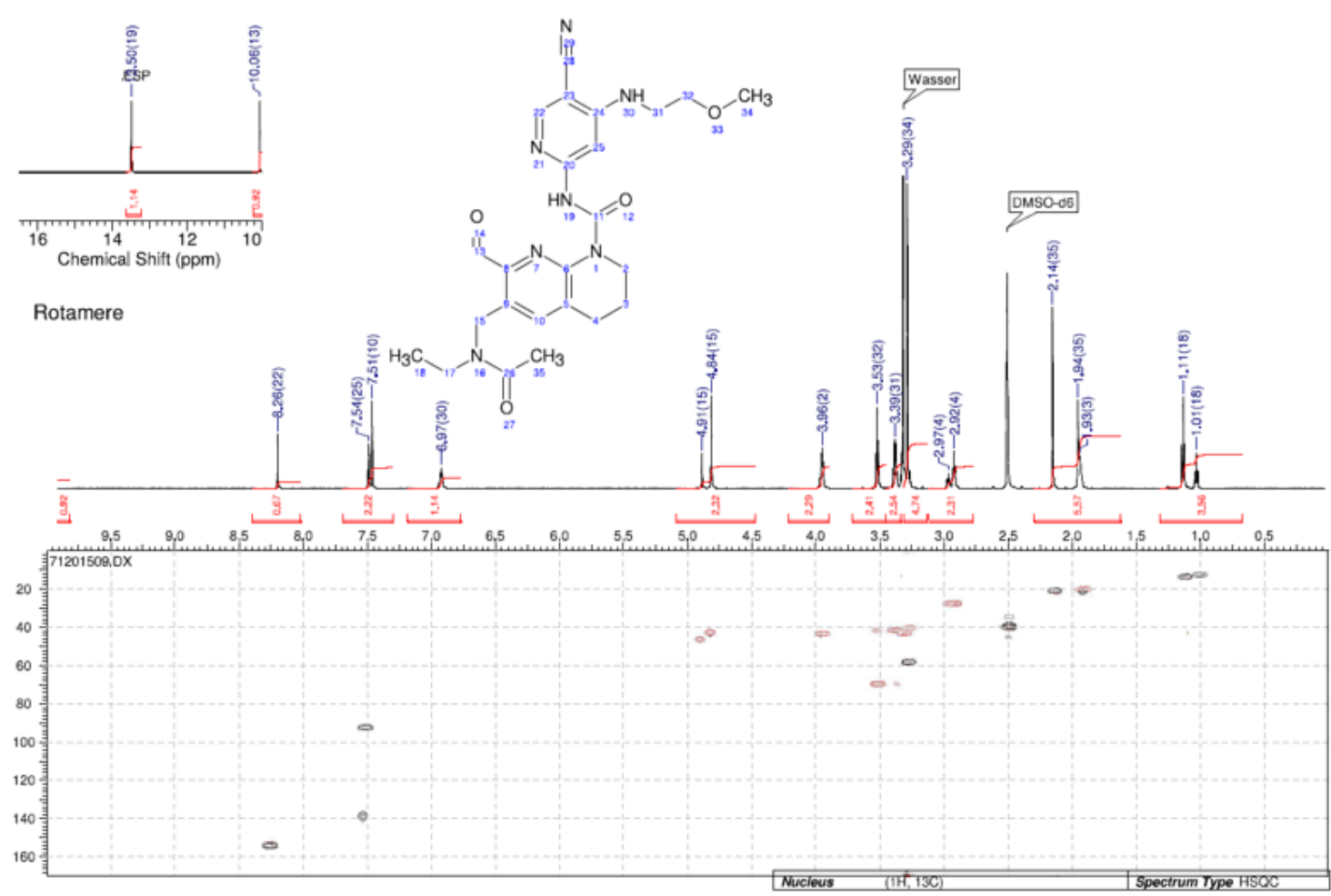

$600 \mathrm{MHz}{ }^{1} \mathrm{H}$ NMR in chloroform- $d_{1}$ of $N$-(5-cyano-4-isopropoxypyridin-2-yl)-7-formyl-6-(( $N$ isopropylacetamido)methyl)-3,4-dihydro-1,8-naphthyridine-1(2H)-carboxamide $\mathbf{6 6}$
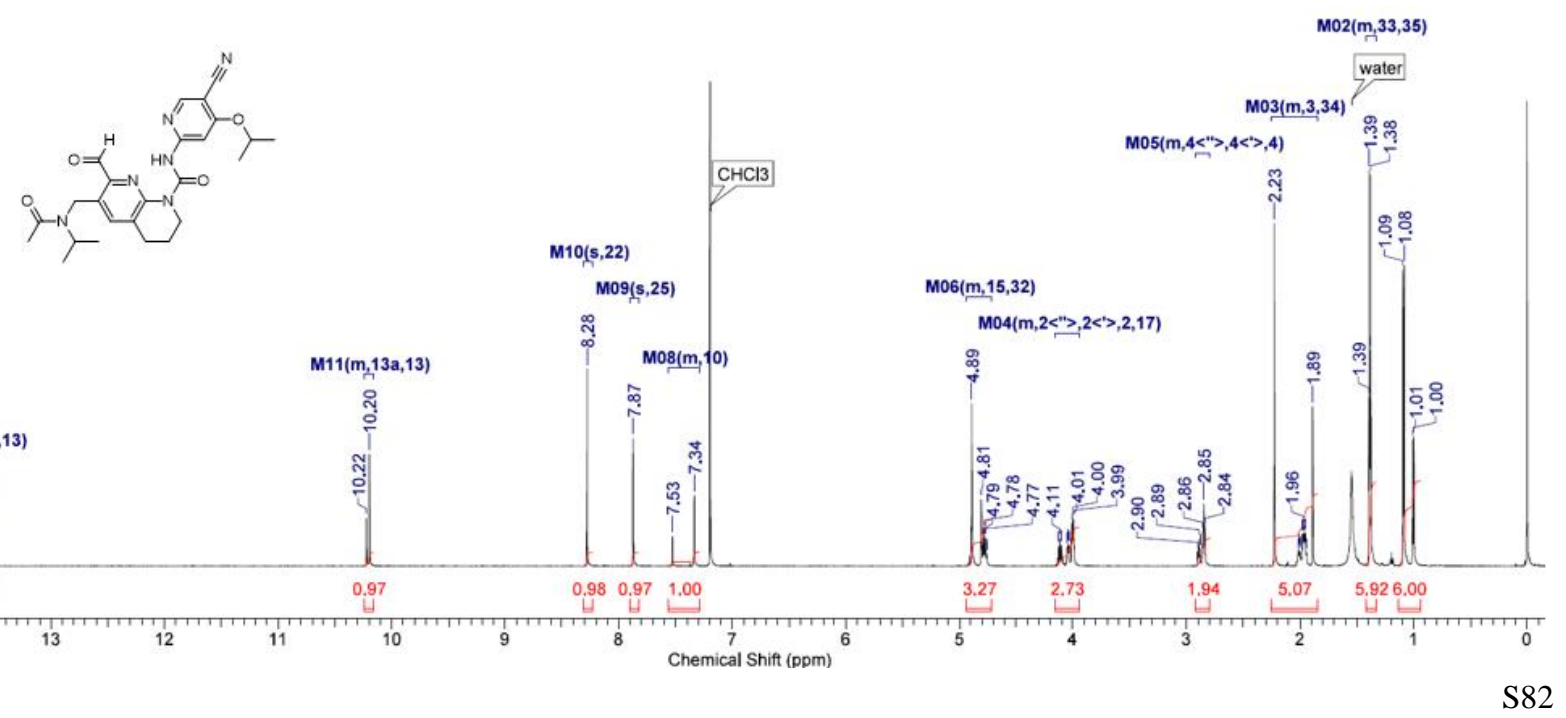
$400 \mathrm{MHz}{ }^{1} \mathrm{H},{ }^{13} \mathrm{C}$ HSQC NMR in DMSO- $d 6$ of $N$-(5-cyano-4-isopropoxypyridin-2-yl)-7-formyl-6-(( $N$ methylmethylsulfonamido)methyl)-3,4-dihydro-1,8-naphthyridine-1 $(2 H)$-carboxamide 67

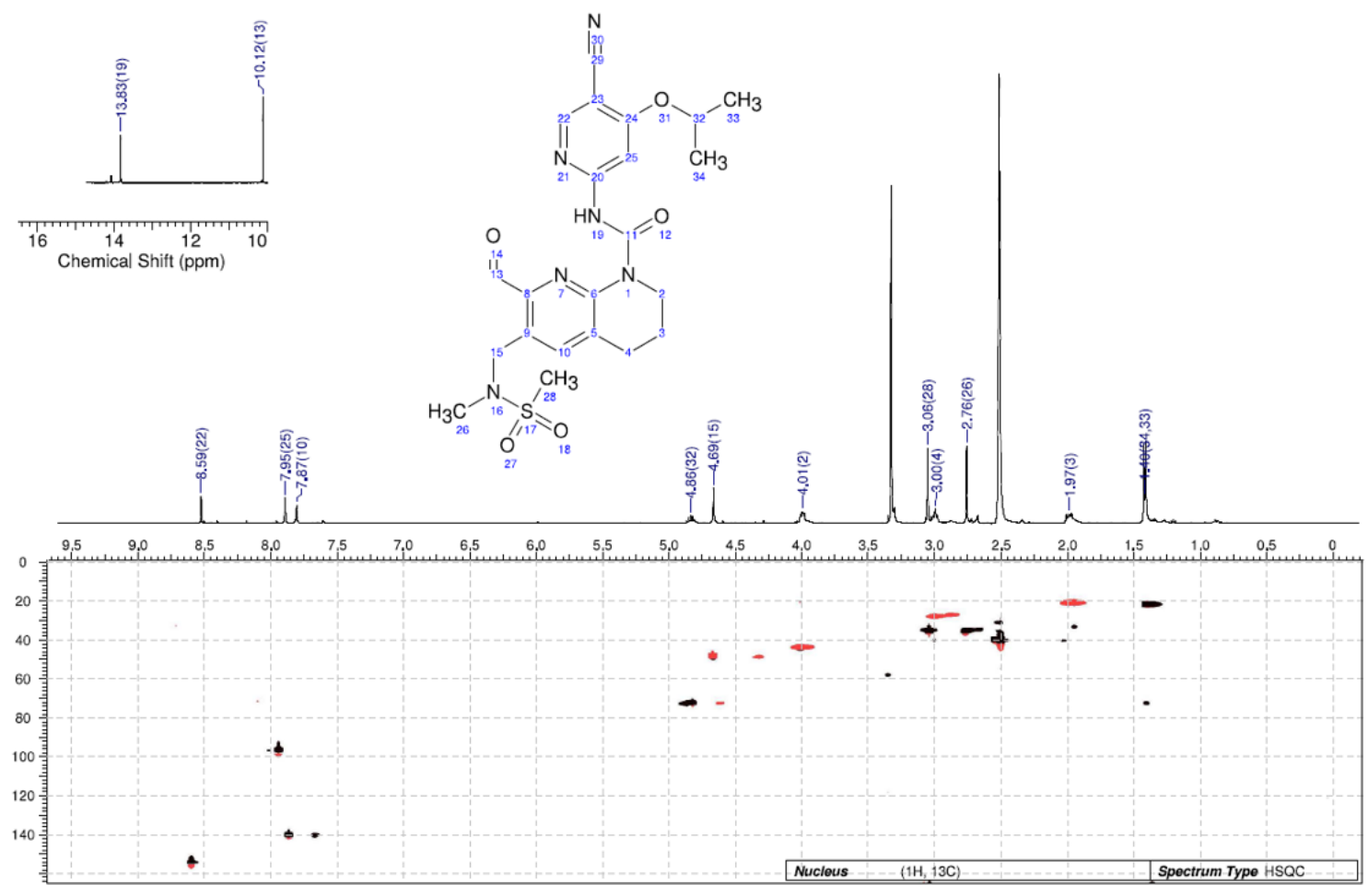

$400 \mathrm{MHz}{ }^{1} \mathrm{H}$ NMR in DMSO- $d_{6}$ of $N$-(5-cyano-4-((2-methoxyethyl)amino)pyridin-2-yl)-7-formyl-6-((3oxomorpholino)methyl)-3,4-dihydro-1,8-naphthyridine-1 $(2 H)$-carboxamide 69
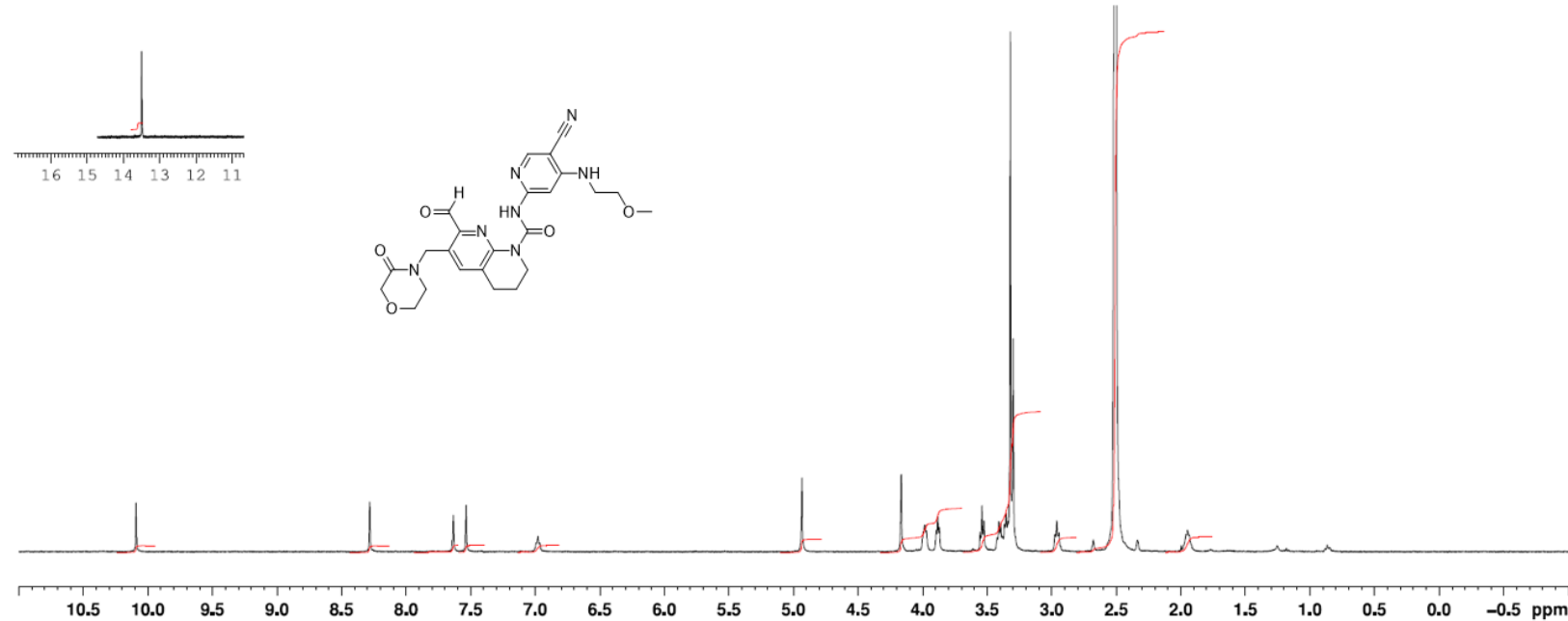
$600 \mathrm{MHz}{ }^{1} \mathrm{H},{ }^{13} \mathrm{C}$ HSQC NMR in DMSO- $d_{6}$ of ( rac)- $N$-(5-cyano-4-((2-methoxyethyl)amino)pyridin-2-yl)-7-formyl6-(1-( $N$-methylacetamido)ethyl)-3,4-dihydro-1,8-naphthyridine-1 $(2 \mathrm{H})$-carboxamide $\mathbf{7 0}$

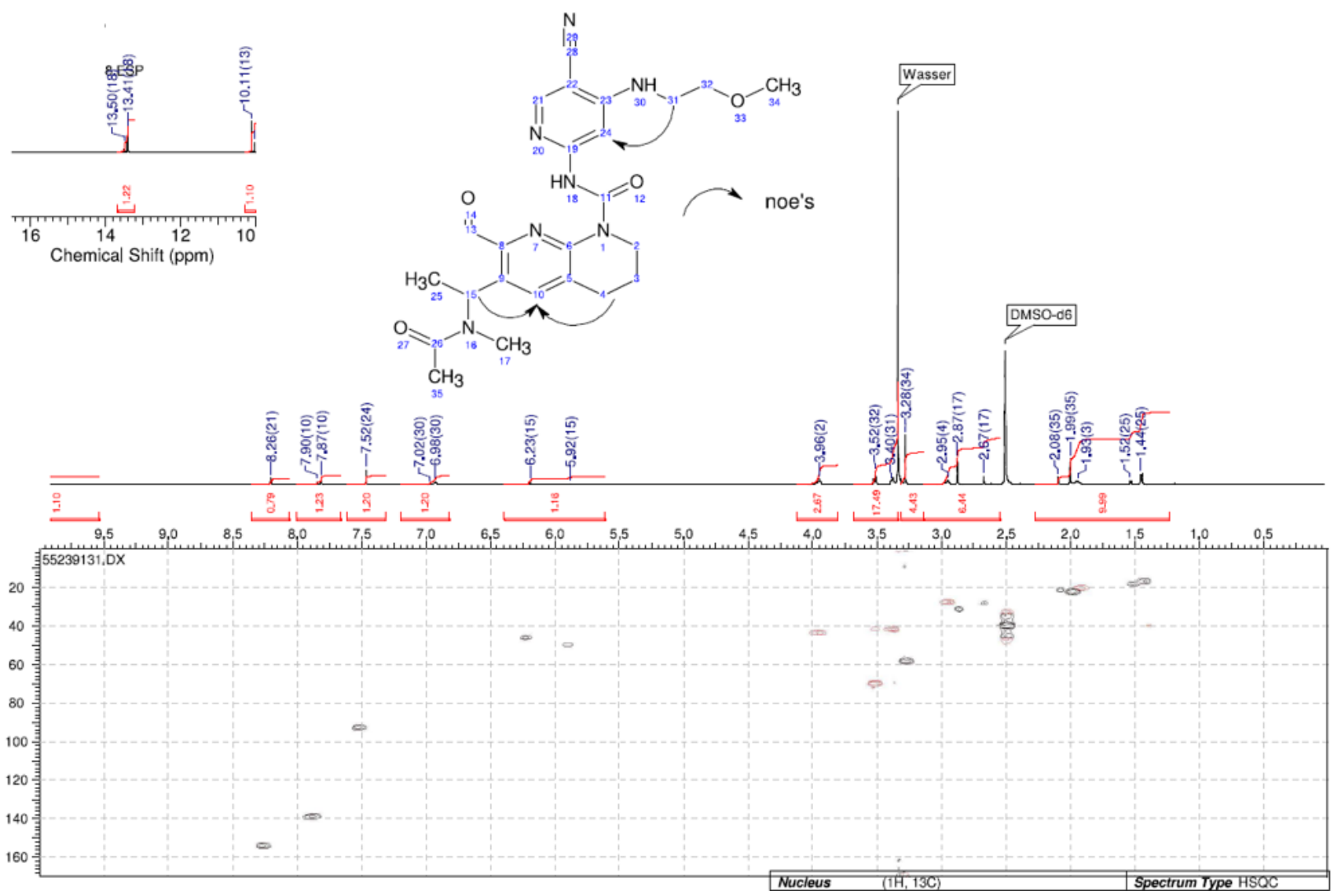


Figure 20 and Table 9

\begin{tabular}{|c|c|c|}
\hline Compound & Analytical data & Synthesis method $\mathrm{S} 11$ \\
\hline 71 & $\begin{array}{l}\text { White solid. LC/MS (Method A): } \mathrm{t}_{\mathrm{R}} 0.61 \mathrm{~min}, \mathrm{~m} / \mathrm{z} 494.4(100 \%, \\
\qquad \mathrm{M}+\mathrm{H}), 492.3(100 \%, \mathrm{M}-\mathrm{H}) .\end{array}$ & $\begin{array}{l}\text { Aza anion urea formation } \\
\text { with } 2.2 \text { equiv. LiHMDS }\end{array}$ \\
\hline 72 & $\begin{array}{l}\text { White solid. LC/MS (Method A): tR } 0.57 \mathrm{~min}, \mathrm{~m} / z 468.3(100 \% \text {, } \\
\mathrm{M}+\mathrm{H}), 274.1(100 \% \text {, pyridineNCO-H), } 466.2(40 \%, \mathrm{M}-\mathrm{H}) \text {. }\end{array}$ & $\begin{array}{l}\text { Aza anion urea formation } \\
\text { with } 2.2 \text { equiv. LiHMDS }\end{array}$ \\
\hline 73 & $\begin{array}{l}\text { Yellow solid. LC/MS (Method A): } \mathrm{t}_{\mathrm{R}} 0.69 \text { and } 0.84 \mathrm{~min} \text { broad } \\
\text { double-peak, hydrate } 0.69 \mathrm{~min} \mathrm{~m} / \mathrm{z} 485.3\left(15 \%, \mathrm{M}-\mathrm{H}_{2} \mathrm{O}+\mathrm{H}\right), 503.4 \\
(100 \%, \mathrm{M}+\mathrm{H}), 483.2\left(30 \%, \mathrm{M}-\mathrm{H}_{2} \mathrm{O}-\mathrm{H}\right), 501.4(35 \%, \mathrm{M}-\mathrm{H}), \\
\text { aldehyde } 0.84 \mathrm{~min} \mathrm{~m} / \mathrm{z} 485.4(100 \% \mathrm{M}+\mathrm{H}), 483.3(100 \%, \mathrm{M}-\mathrm{H}) .\end{array}$ & Aza anion urea formation \\
\hline 74 & $\begin{array}{l}\text { White solid. LC/MS (Method A): } \mathrm{t}_{\mathrm{R}} 0.73 \text { and } 0.88 \mathrm{~min} \text { broad double- } \\
\text { peak, hydrate } 0.73 \mathrm{~min} m / z 487.4\left(15 \%, \mathrm{M}-\mathrm{H}_{2} \mathrm{O}+\mathrm{H}\right), 505.3(100 \% \text {, } \\
\mathrm{M}+\mathrm{H}), 485.3\left(30 \%, \mathrm{M}-\mathrm{H}_{2} \mathrm{O}-\mathrm{H}\right), 503.3(60 \%, \mathrm{M}-\mathrm{H}), \text { aldehyde } 0.88 \\
\min \mathrm{m} / \mathrm{z} 487.3(100 \% \mathrm{M}+\mathrm{H}), 485.2(100 \%, \mathrm{M}-\mathrm{H}) .\end{array}$ & Aza anion urea formation \\
\hline 75 & $\begin{array}{l}\text { White solid. LC/MS (Method A): tR } 0.72 \text { min single peak with front } \\
\text { tail, } m / z \text {. } 520.3(100 \%, \mathrm{M}+\mathrm{H}), 217.2(100 \% \text {, pyridineNCO-H), } 518.3 \\
(90 \%, \mathrm{M}-\mathrm{H}) .\end{array}$ & CDT urea formation \\
\hline 76 & $\begin{array}{l}\text { White solid. LC/MS (Method A): tR } 0.95 \mathrm{~min}, \mathrm{~m} / \mathrm{z} 528.3(100 \% \text {, } \\
\mathrm{M}+\mathrm{H}), 217.2(95 \% \text {, pyridineNCO-H), } 526.4(70 \%, \mathrm{M}-\mathrm{H}), 572.5 \\
\left(60 \%, \mathrm{M}+\mathrm{HCO}_{2}^{-}\right) .\end{array}$ & CDT urea formation \\
\hline 77 & $\begin{array}{l}\text { White solid. LC/MS (Method A): tR } 0.70 \mathrm{~min}, \mathrm{~m} / z 509.4(100 \% \text {, } \\
\mathrm{M}+\mathrm{H}), 217.1(100 \% \text {, pyridineNCO-H), } 507.5(80 \%, \mathrm{M}-\mathrm{H}) \text {. }\end{array}$ & Aza anion urea formation \\
\hline 78 & $\begin{array}{c}\text { White crystalline solid. LC/MS (Method A): } t_{R} 0.68 \mathrm{~min}, \mathrm{~m} / z, 523.3 \\
(100 \%, \mathrm{M}+\mathrm{H}), 217.1(100 \% \text {, pyridineNCO-H), } 521.3(50 \%, \mathrm{M}-\mathrm{H}), \\
567.3\left(25 \%, \mathrm{M}+\mathrm{HCO}_{2}^{-}\right) .\end{array}$ & Aza anion urea formation \\
\hline 79 & $\begin{array}{c}\text { White crystalline solid. LC/MS (Method A): } \mathrm{t}_{\mathrm{R}} 0.73 \mathrm{~min}, \mathrm{~m} / \mathrm{z}, 559.3 \\
(100 \%, \mathrm{M}+\mathrm{H}), 217.0(100 \% \text {, pyridineNCO-H), } 557.3(25 \%, \mathrm{M}-\mathrm{H}), \\
603.3\left(10 \%, \mathrm{M}+\mathrm{HCO}_{2}^{-}\right) .\end{array}$ & CDT urea formation \\
\hline $80 / 81$ & $\begin{array}{l}\text { White crystalline solids. LC/MS (Method A): tR } 0.71 \mathrm{~min}, \mathrm{~m} / z \text {. } 521.5 \\
(100 \%, \mathrm{M}+\mathrm{H}), 217.1(100 \% \text {, pyridineNCO-H), } 519.3(20 \%, \mathrm{M}-\mathrm{H}) .\end{array}$ & CDT urea formation \\
\hline $82 / 83$ & $\begin{array}{l}\text { White solids. LC/MS (Method A): } t_{\mathrm{R}} 0.67 \mathrm{~min}, \mathrm{~m} / z 521.3(100 \% \text {, } \\
\mathrm{M}+\mathrm{H}), 217.1(100 \% \text {, pyridineNCO-H), } 519.2(45 \%, \mathrm{M}-\mathrm{H}) .\end{array}$ & CDT urea formation \\
\hline
\end{tabular}




\begin{tabular}{|c|c|c|}
\hline 85 & $\begin{array}{c}\text { White crystalline solid, } \mathrm{mp} 220{ }^{\circ} \mathrm{C}(\mathrm{DSC}) . \mathrm{LC} / \mathrm{MS}(\text { Method } \mathrm{A}): \mathrm{t}_{\mathrm{R}} \\
0.82 \mathrm{~min}, \mathrm{~m} / \mathrm{z} 507.1(100 \%, \mathrm{M}+\mathrm{H}), 217.0(100 \% \text {, pyridineNCO-H), } \\
505.1(70 \%, \mathrm{M}-\mathrm{H}) .\end{array}$ & Aza anion urea formation \\
\hline 86 & $\begin{array}{c}\text { Pale-yellow solid. LC/MS (Method A): tR } 0.71 \mathrm{~min}, \mathrm{~m} / z \text { } 507.3 \\
(100 \%, \mathrm{M}+\mathrm{H}), 217.1(100 \% \text {, pyridineNCO-H), } 505.3(40 \%, \mathrm{M}-\mathrm{H}) .\end{array}$ & Aza anion urea formation \\
\hline 87 & $\begin{array}{c}\text { White solid. LC/MS (Method A): } \mathrm{t}_{\mathrm{R}} 0.74 \mathrm{~min}, \mathrm{~m} / \mathrm{z}, 535.4(100 \% \text {, } \\
\mathrm{M}+\mathrm{H}), 217.1(100 \%, \text { pyridineNCO-H), } 533.4(25 \%, \mathrm{M}-\mathrm{H}), 579.5 \\
\left(20 \%, \mathrm{M}+\mathrm{HCO}_{2}^{-}\right) .\end{array}$ & CDT urea formation \\
\hline 88 & $\begin{array}{c}\text { White solid. LC/MS (Method A): tr } 0.91 \mathrm{~min}, \mathrm{~m} / \mathrm{z} 535.4(100 \%, \\
\mathrm{M}+\mathrm{H}), 217.1(100 \% \text {, pyridineNCO-H), } 533.4(45 \%, \mathrm{M}-\mathrm{H}), 579.3 \\
\left(15 \%, \mathrm{M}+\mathrm{HCO}_{2}^{-}\right) .\end{array}$ & CDT urea formation \\
\hline $89 / 90$ & $\begin{array}{l}\text { White crystalline solids, } \mathrm{mp} 134 \text { and } 136{ }^{\circ} \mathrm{C}(\mathrm{DSC}) . \mathrm{LC} / \mathrm{MS} \\
\text { (Method A): tR } 0.78 \mathrm{~min}, \mathrm{~m} / \mathrm{z} 521.2(100 \%, \mathrm{M}+\mathrm{H}), 231.1(100 \% \text {, } \\
\text { pyridineNCO-H), } 519.1(70 \%, \mathrm{M}-\mathrm{H}), 565.3\left(20 \%, \mathrm{M}+\mathrm{HCO}_{2}^{-}\right)\end{array}$ & CDT urea formation \\
\hline 91 & $\begin{array}{c}\text { Brown crystalline solid, mp } 192{ }^{\circ} \mathrm{C}(\mathrm{DSC}) . \mathrm{LC} / \mathrm{MS}\left(\text { Method A): } \mathrm{t}_{\mathrm{R}}\right. \\
0.63 \mathrm{~min}, \mathrm{~m} / z 481.3(100 \%, \mathrm{M}+\mathrm{H}), 217.1(20 \% \text {, pyridineNCO-H), } \\
479.2(100 \%, \mathrm{M}-\mathrm{H}) .\end{array}$ & CDT urea formation \\
\hline
\end{tabular}

Table S3 Analytical data and the urea bond forming approach used to prepare the compounds included in Figure 20 of the main text. 
$400 \mathrm{MHz}{ }^{1} \mathrm{H}$ NMR in DMSO- $d 6$ of $N$-(5-cyano-4-(4-((dimethylamino)methyl)-4-hydroxypiperidin-1-yl)pyridin-2yl)-7-formyl-6-(hydroxymethyl)-3,4-dihydro-1,8-naphthyridine-1(2H)-carboxamide 71 (1:1 mixture of the internal hemiacetal and aldehyde tautomers)

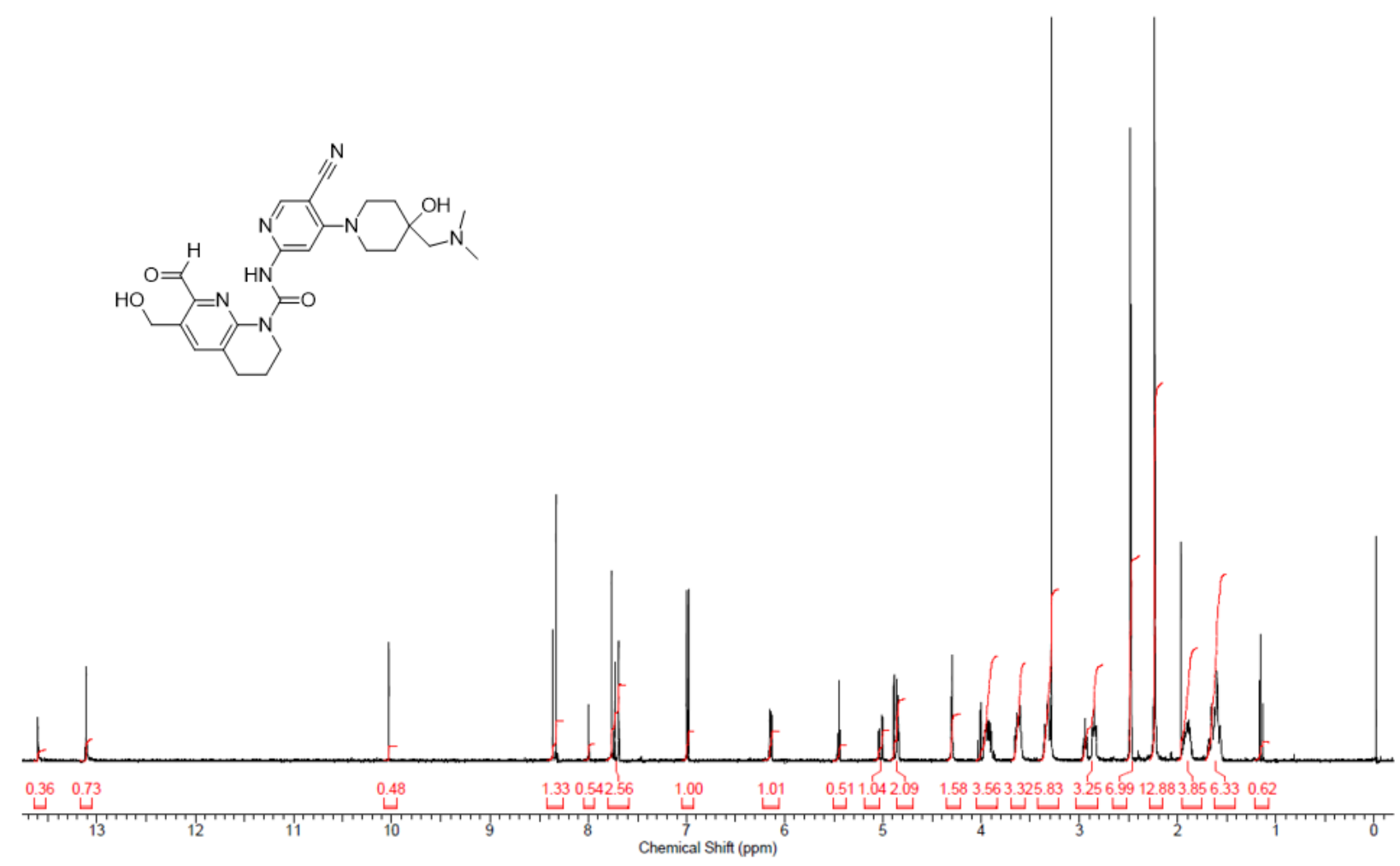


$400 \mathrm{MHz}{ }^{1} \mathrm{H}$ NMR in DMSO- $d_{6}$ of $(\mathrm{rac})-\mathrm{N}$-(5-cyano-4-((3-(dimethylamino)-2-hydroxy-2-

methylpropyl)amino)pyridin-2-yl)-7-formyl-6-(hydroxymethyl)-3,4-dihydro-1,8-naphthyridine-1 $(2 H)$-carboxamide $\underline{72}$

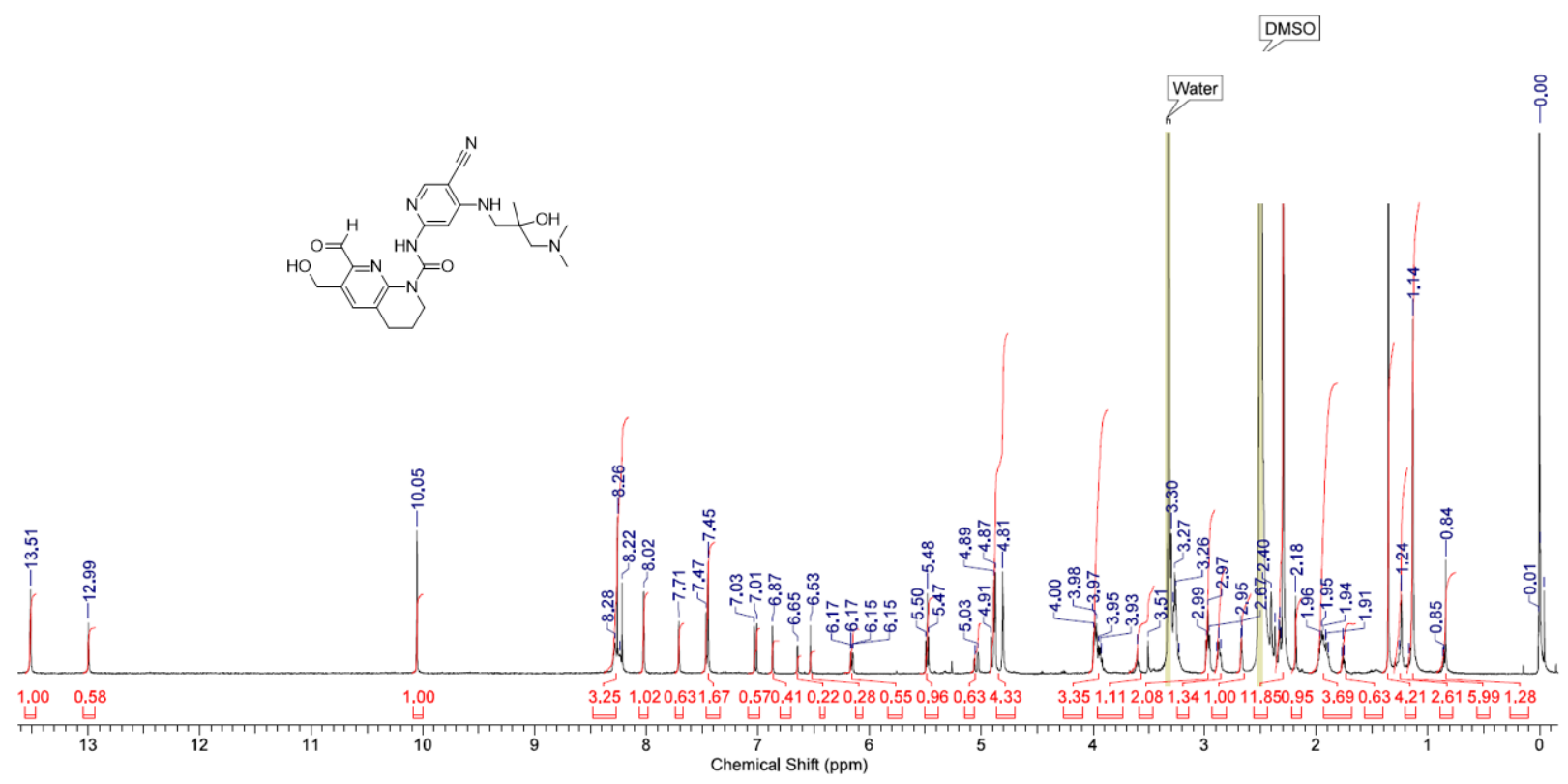


$600 \mathrm{MHz}{ }^{1} \mathrm{H},{ }^{13} \mathrm{C}$ HSQC NMR in DMSO- $d_{6}$ of $N$-(5-cyano-4-((1-methylpiperidin-4-yl)methoxy)pyridin-2-yl)-6(difluoromethyl)-7-formyl-3,4-dihydro-1,8-naphthyridine-1 $(2 H)$-carboxamide $\mathbf{7 3}$

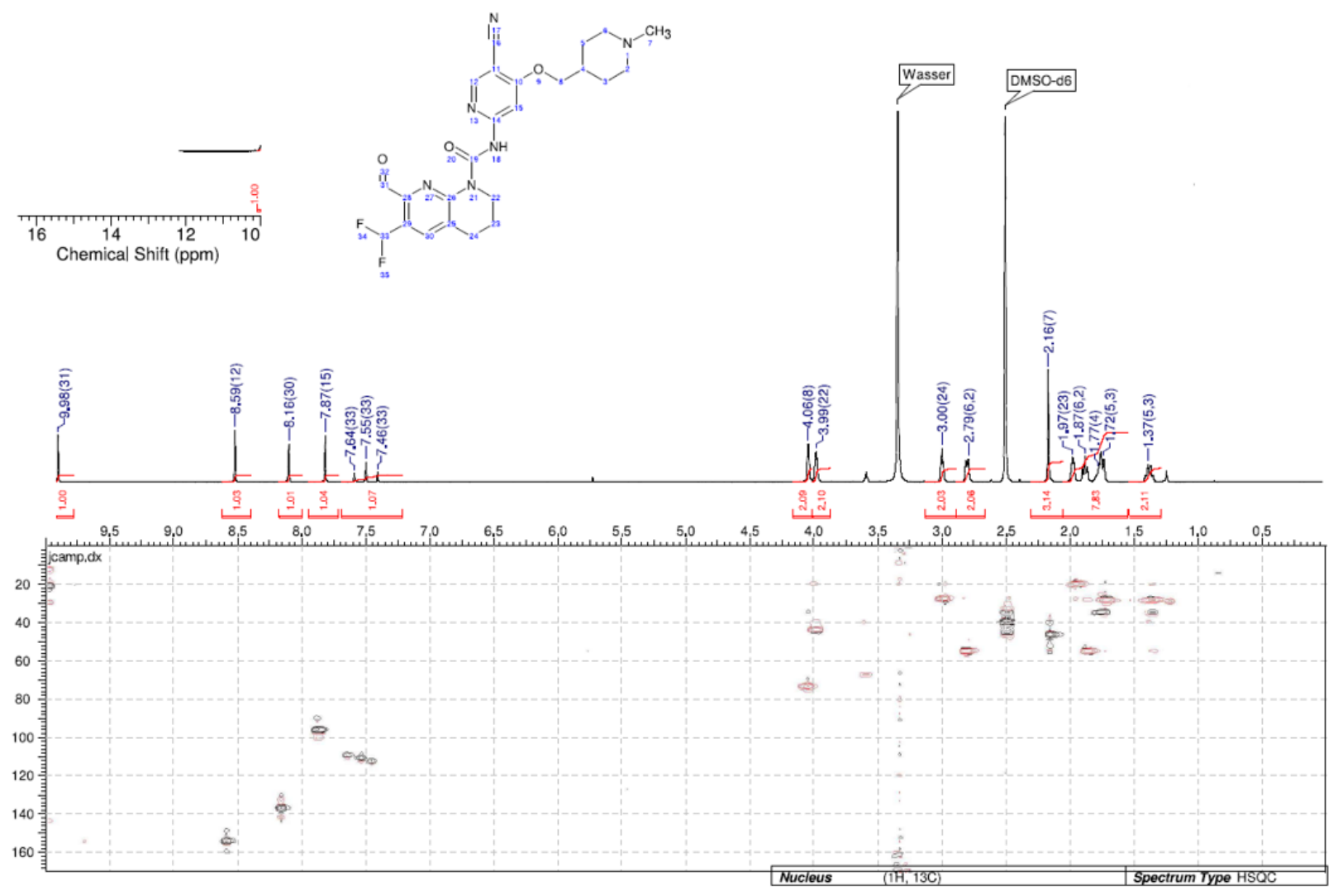


$600 \mathrm{MHz}{ }^{1} \mathrm{H},{ }^{13} \mathrm{C}$ HSQC NMR in DMSO- $d_{6}$ of $N$-(5-cyano-4-(3-(dimethylamino)-2,2-dimethylpropoxy)pyridin-2yl)-6-(difluoromethyl)-7-formyl-3,4-dihydro-1,8-naphthyridine-1 $(2 H)$-carboxamide $\mathbf{7 4}$
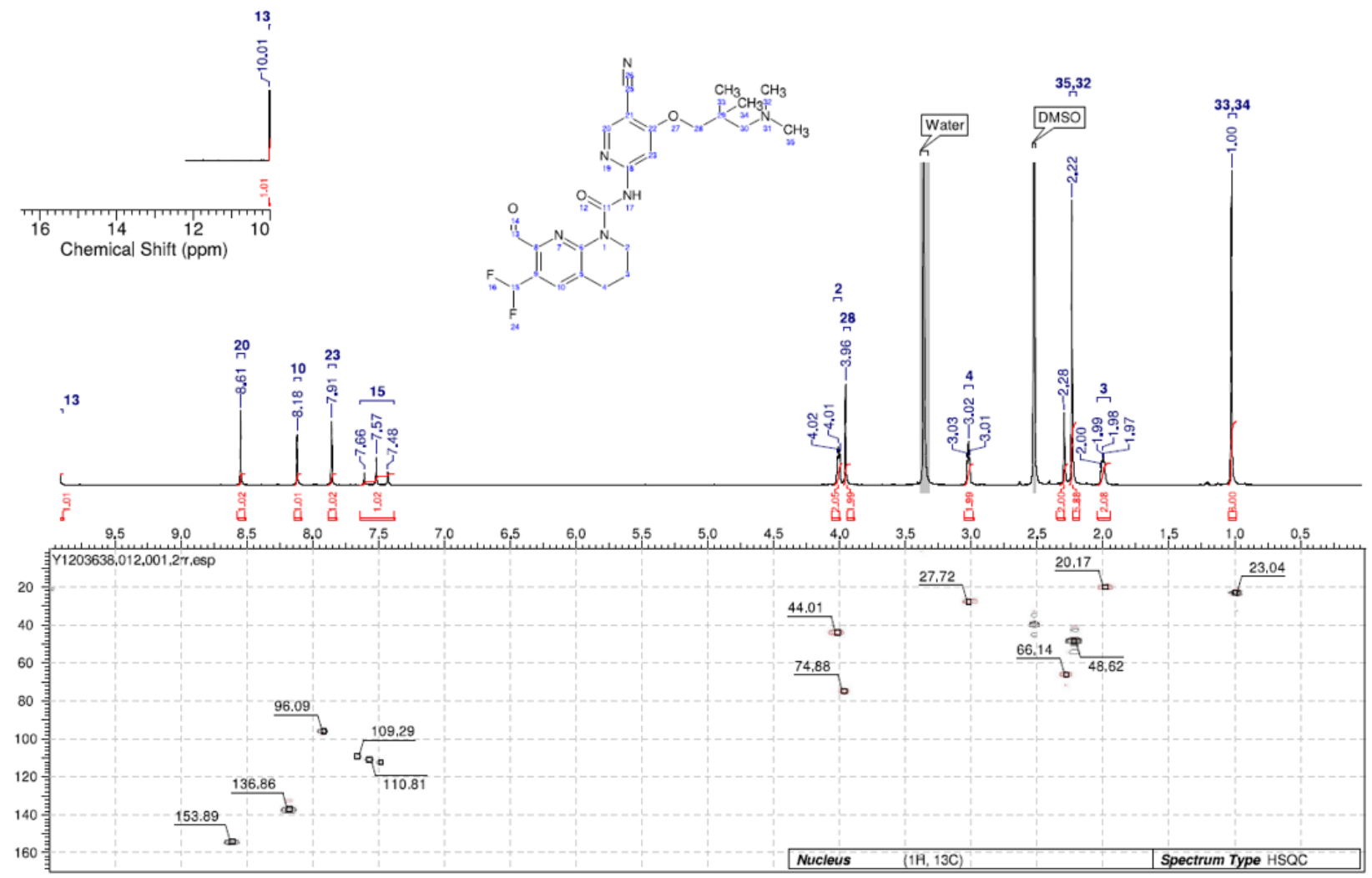
$600 \mathrm{MHz}{ }^{1} \mathrm{H}$ NMR in DMSO- $d_{6}$ of $N$-(5-cyano-4-((2-methoxyethyl)amino)pyridin-2-yl)-7-formyl-6-(1-(oxetan-3yl)piperidin-4-yl)-3,4-dihydro-1,8-naphthyridine-1 $(2 H)$-carboxamide $\mathbf{7 5}$

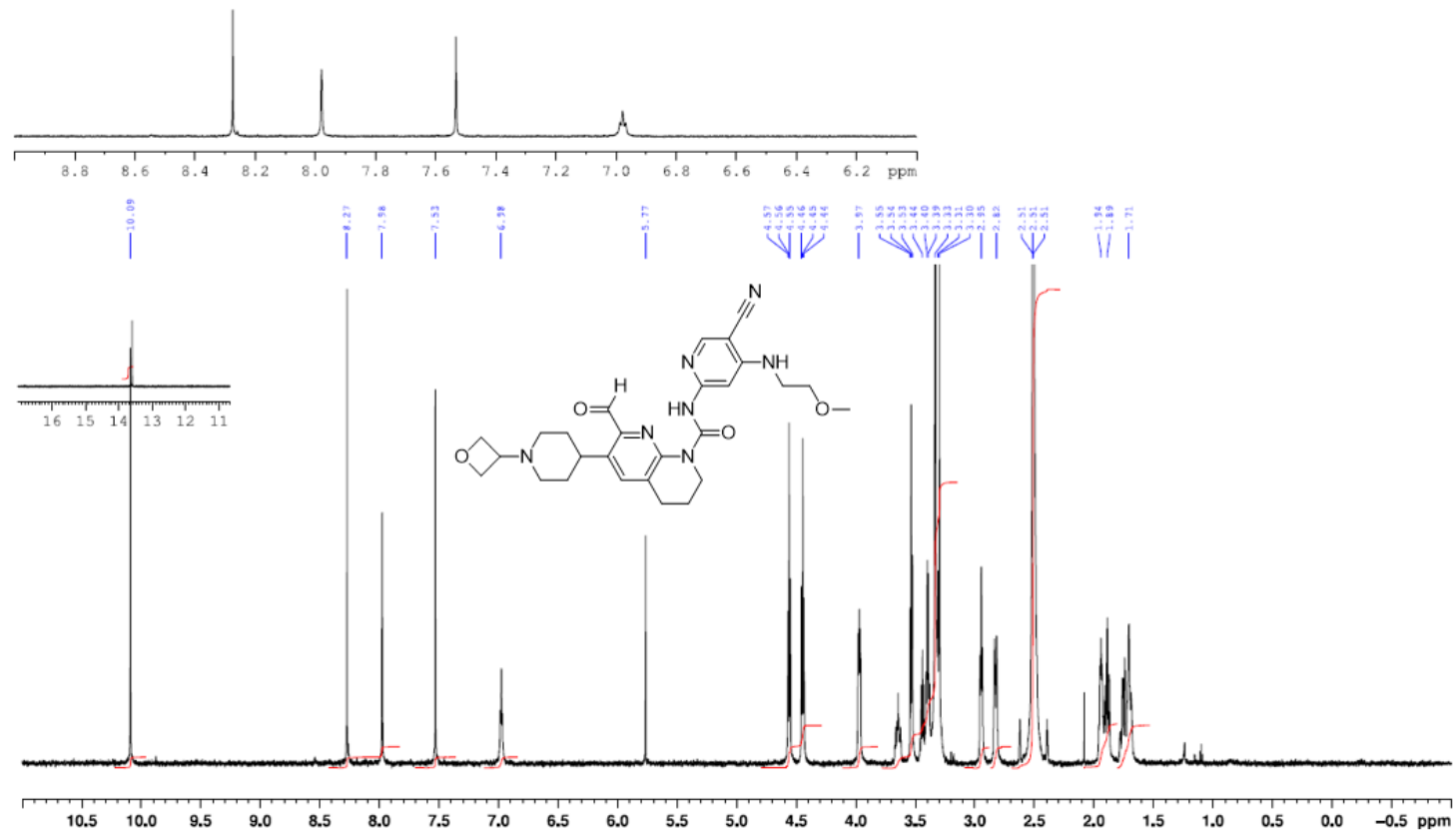

$600 \mathrm{MHz}^{1} \mathrm{H}$ NMR in DMSO- $d 6$ of $N$-(5-cyano-4-((2-methoxyethyl)amino)pyridin-2-yl)-7-formyl-6-(1-(2,2,2trifluoroethyl)piperidin-4-yl)-3,4-dihydro-1,8-naphthyridine-1(2H)-carboxamide $\mathbf{7 6}$

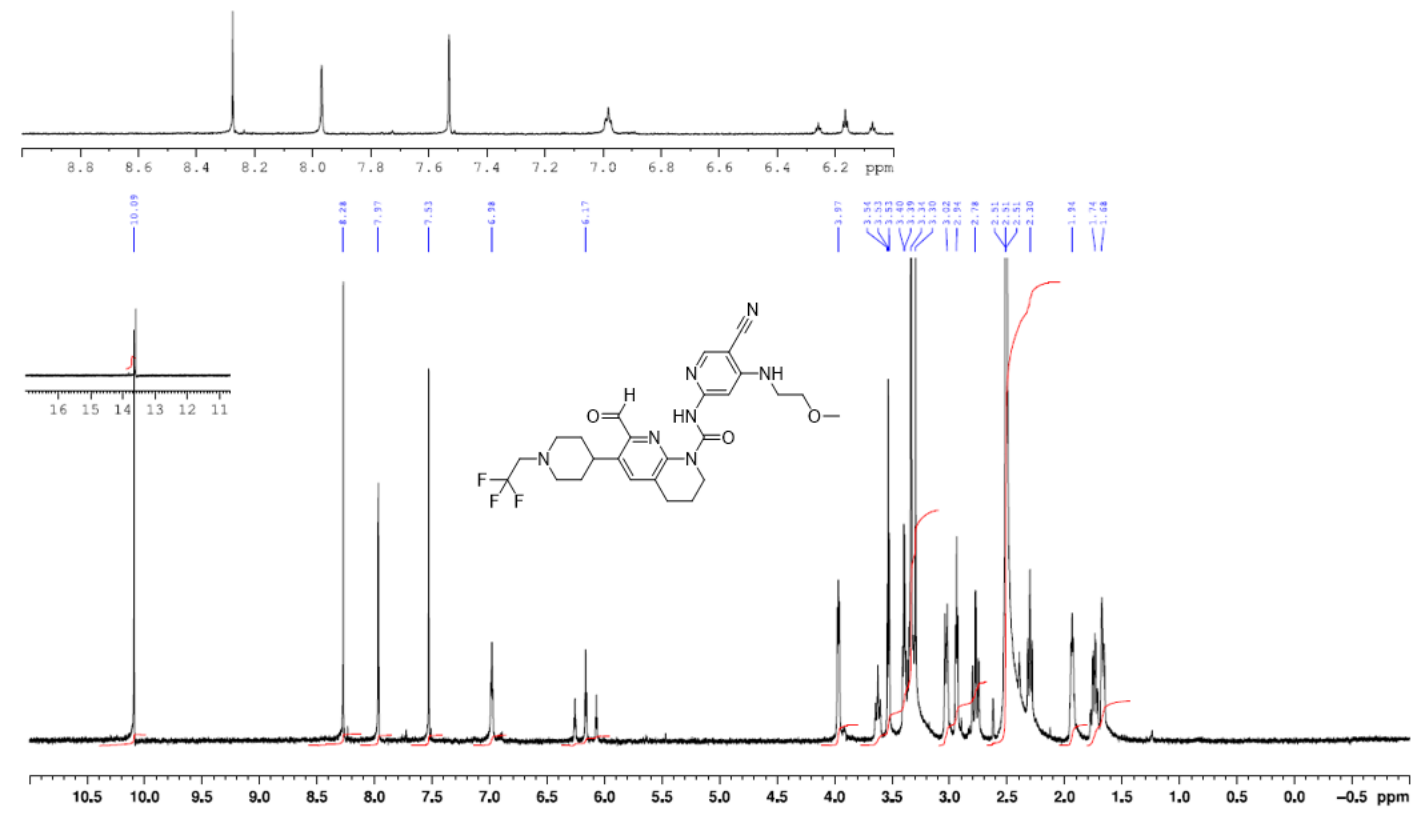


$600 \mathrm{MHz}{ }^{1} \mathrm{H},{ }^{13} \mathrm{C}$ HSQC NMR in DMSO-d ${ }_{6}$ of $N$-(5-cyano-4-((2-methoxyethyl)amino)pyridin-2-yl)-6-((2-

(dimethylamino)- $N$-methylacetamido)methyl)-7-formyl-3,4-dihydro-1,8-naphthyridine-1(2H)-carboxamide 77

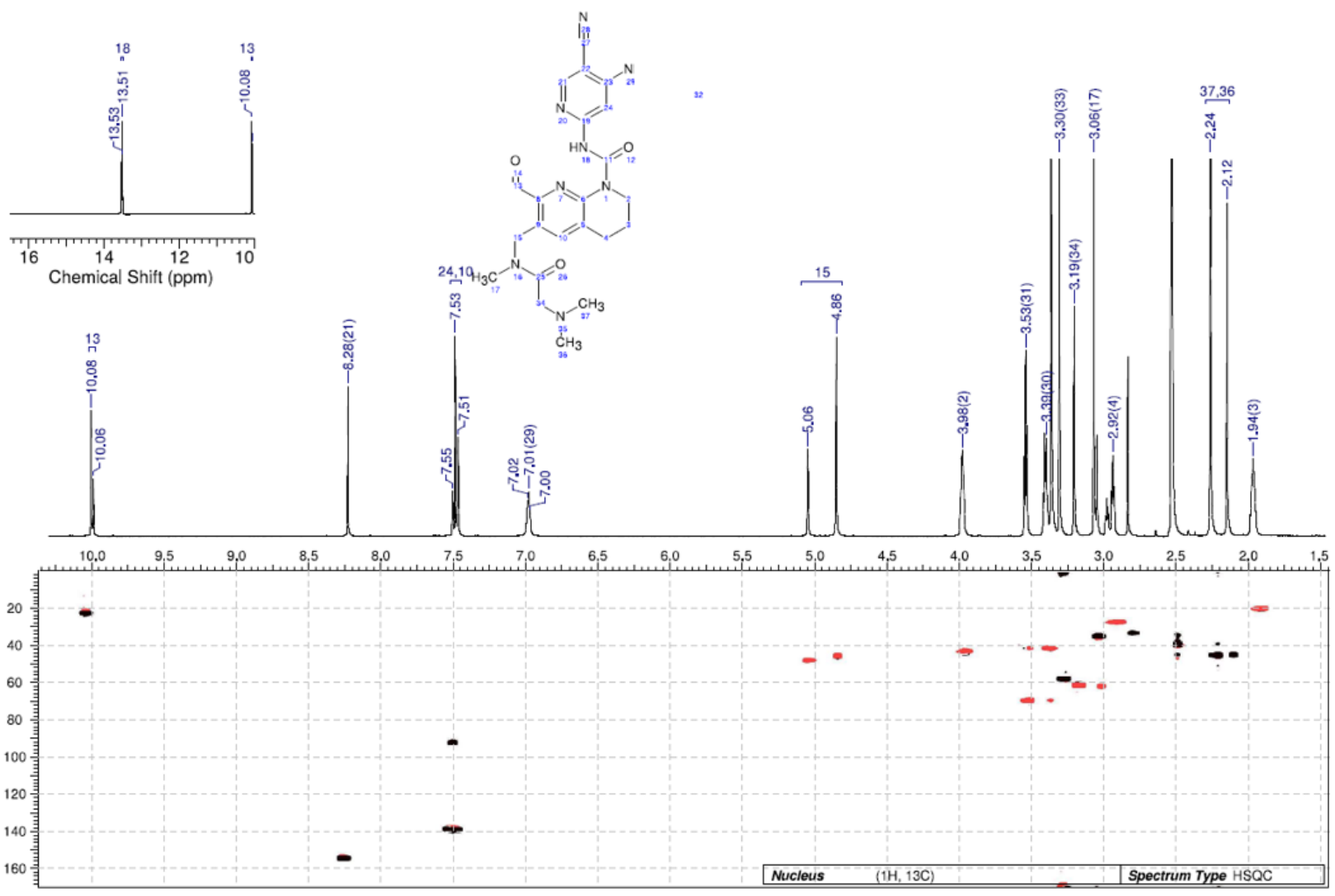


$600 \mathrm{MHz}{ }^{1} \mathrm{H}$ NMR in DMSO- $d_{6}$ of $N$-(5-cyano-4-((2-methoxyethyl)amino)pyridin-2-yl)-6-((N-(2-

(dimethylamino)ethyl)acetamido)methyl)-7-formyl-3,4-dihydro-1,8-naphthyridine-1(2H)-carboxamide 78
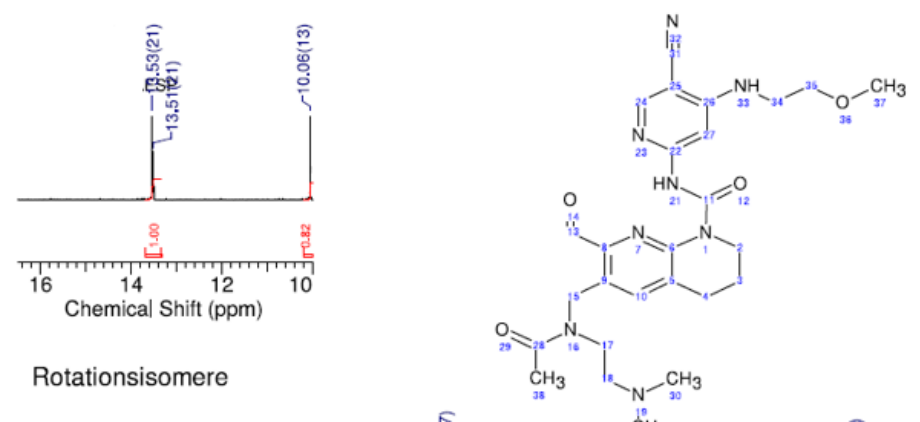

Rotationsisomere
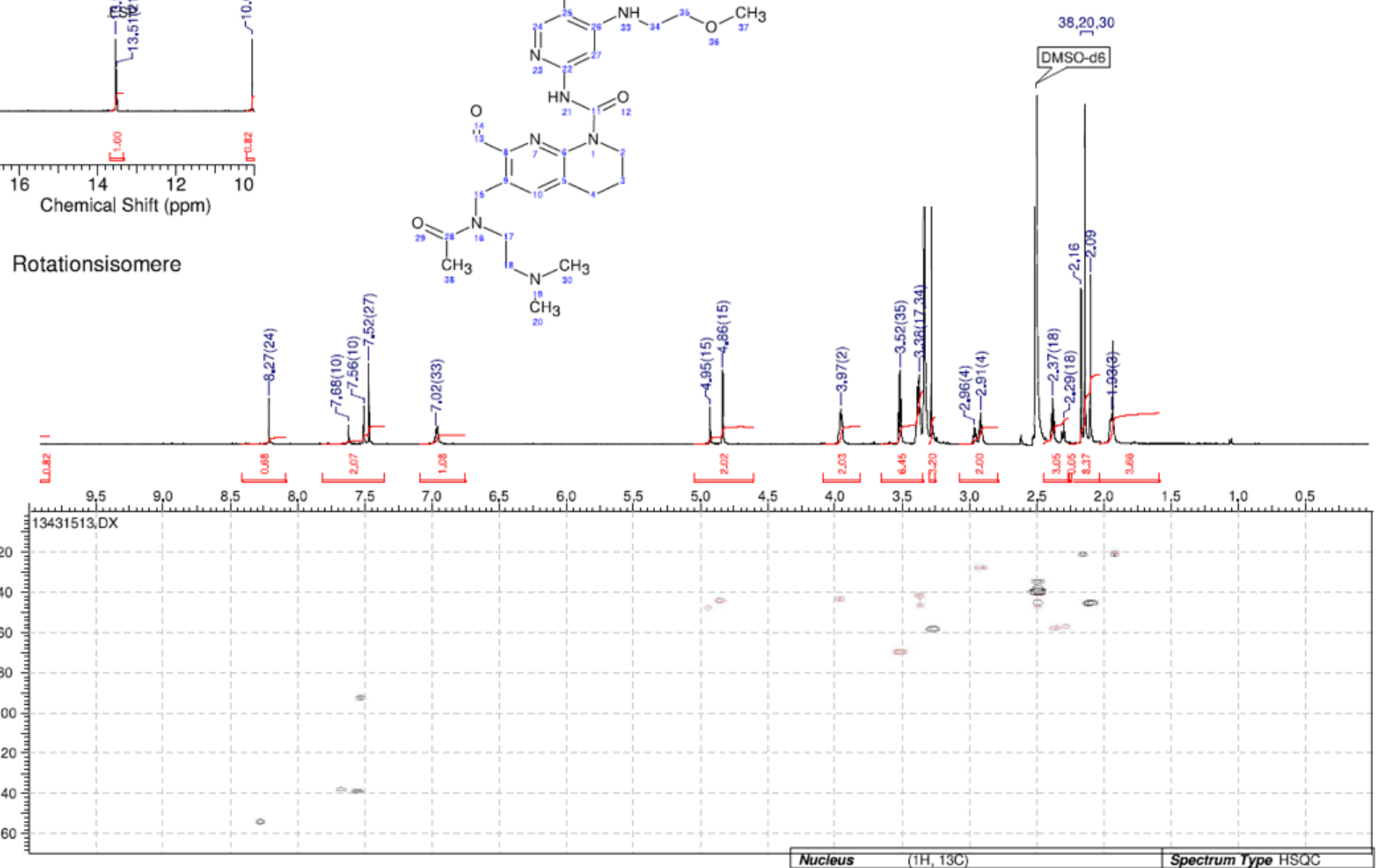
$600 \mathrm{MHz}{ }^{1} \mathrm{H}$ NMR in DMSO- $d_{6}$ of $N$-(5-cyano-4-((2-methoxyethyl)amino)pyridin-2-yl)-6-((N-(2-

(dimethylamino)ethyl)methylsulfonamido)methyl)-7-formyl-3,4-dihydro-1,8-naphthyridine-1 $(2 H)$-carboxamide 79

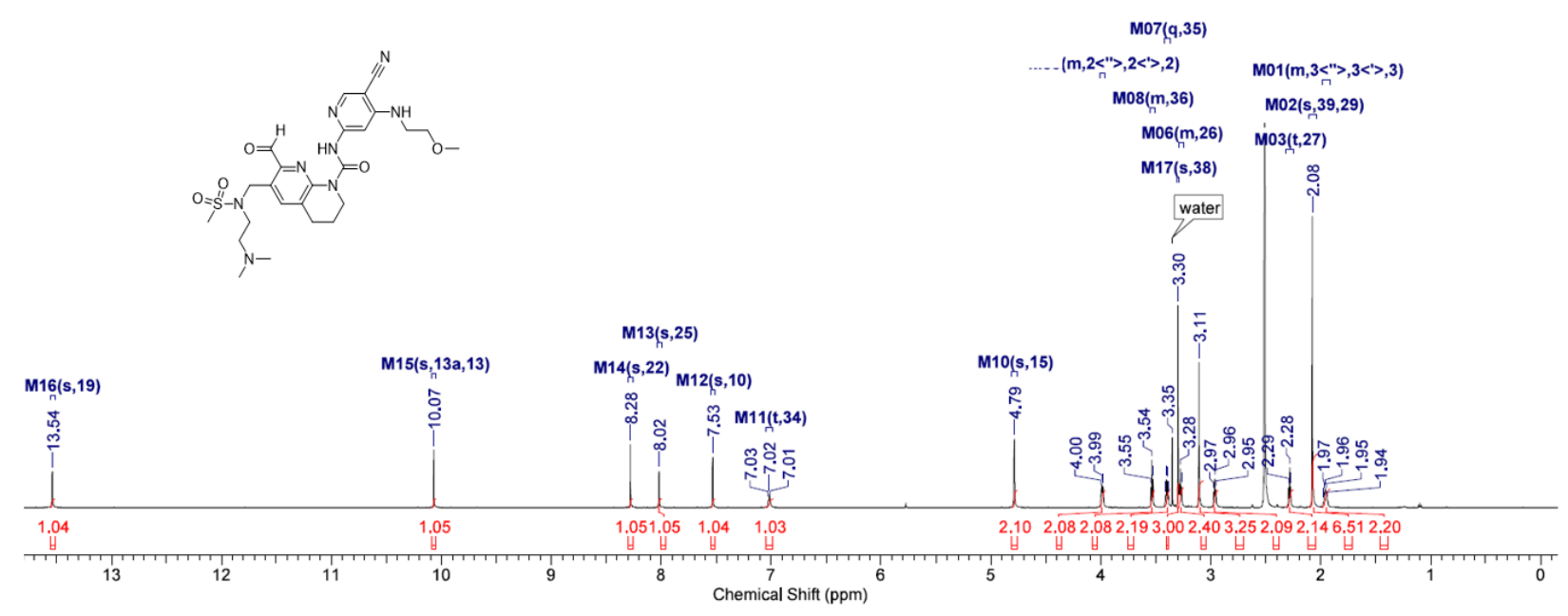

$400 \mathrm{MHz}{ }^{1} \mathrm{H}$ NMR in DMSO- $d_{6}$ of $(S)$ - and $(R)-N$-(5-cyano-4-((2-methoxyethyl)amino)pyridin-2-yl)-6-((3-

(dimethylamino)-2-oxopyrrolidin-1-yl)methyl)-7-formyl-3,4-dihydro-1,8-naphthyridine-1(2H)-carboxamide 80 and $\underline{81}$

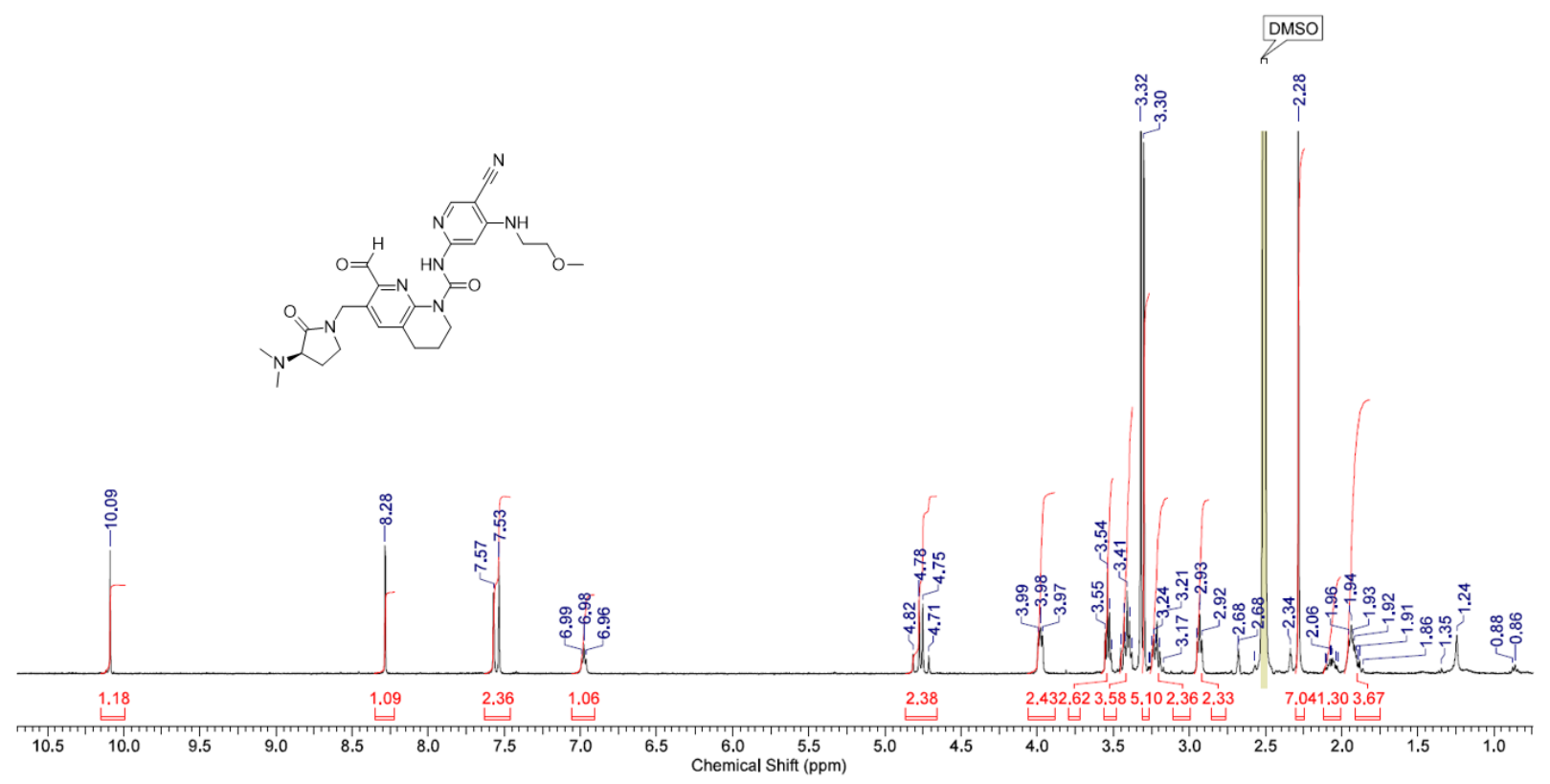


$400 \mathrm{MHz}{ }^{1} \mathrm{H}$ NMR in DMSO- $d_{6}$ of $(R)$ - and $(S)-N$-(5-cyano-4-((2-methoxyethyl)amino)pyridin-2-yl)-6-((4-

(dimethylamino)-2-oxopyrrolidin-1-yl)methyl)-7-formyl-3,4-dihydro-1,8-naphthyridine-1(2H)-carboxamide 82 and $\underline{83}$
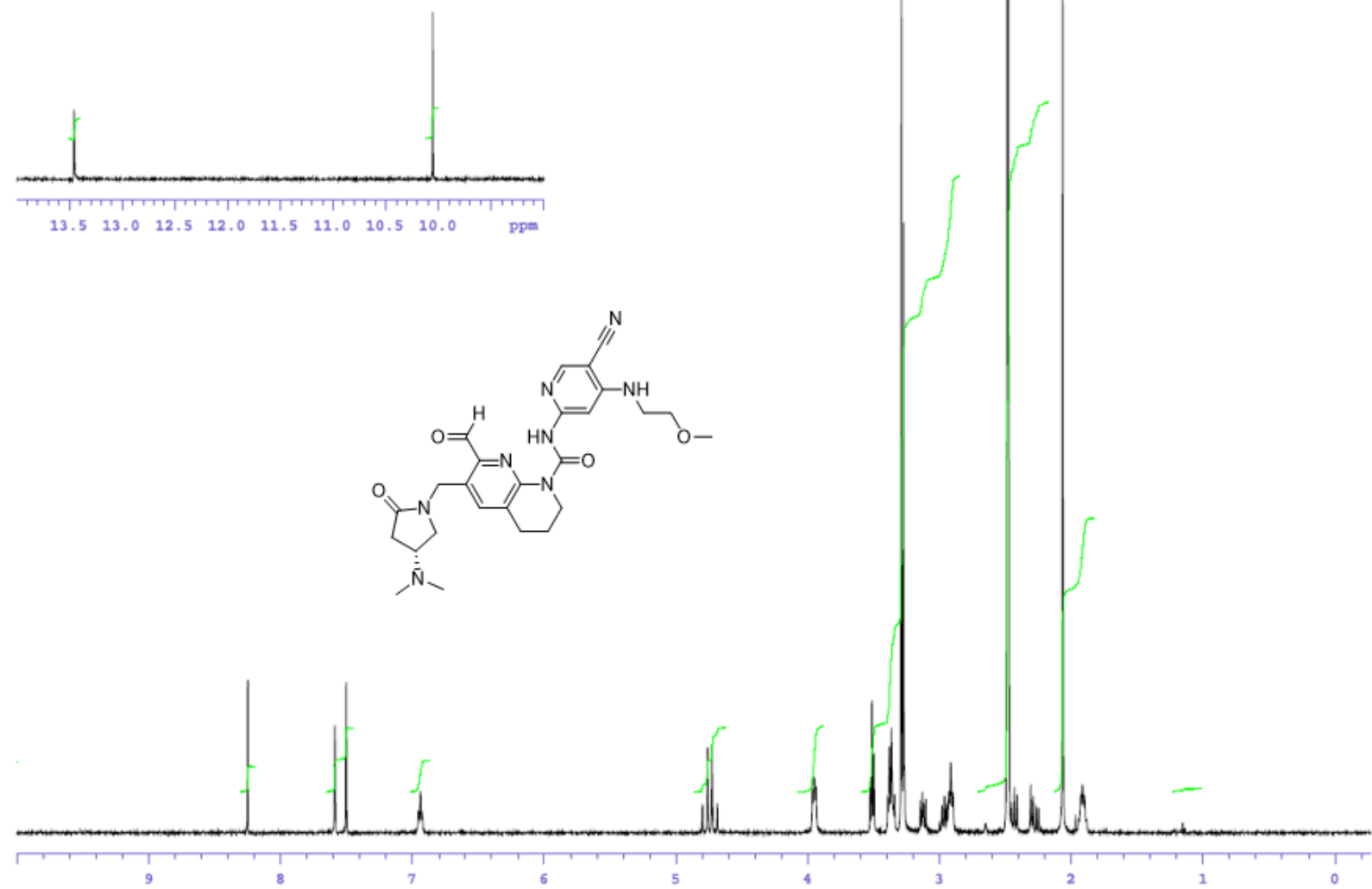
$600 \mathrm{MHz}{ }^{1} \mathrm{H}$ NMR in chloroform- $d_{1}$ of $N$-(5-cyano-4-((2-methoxyethyl)amino)pyridin-2-yl)-7-formyl-6-((4-methyl3-oxopiperazin-1-yl)methyl)-3,4-dihydro-1,8-naphthyridine-1(2H)-carboxamide $\mathbf{8 5}$

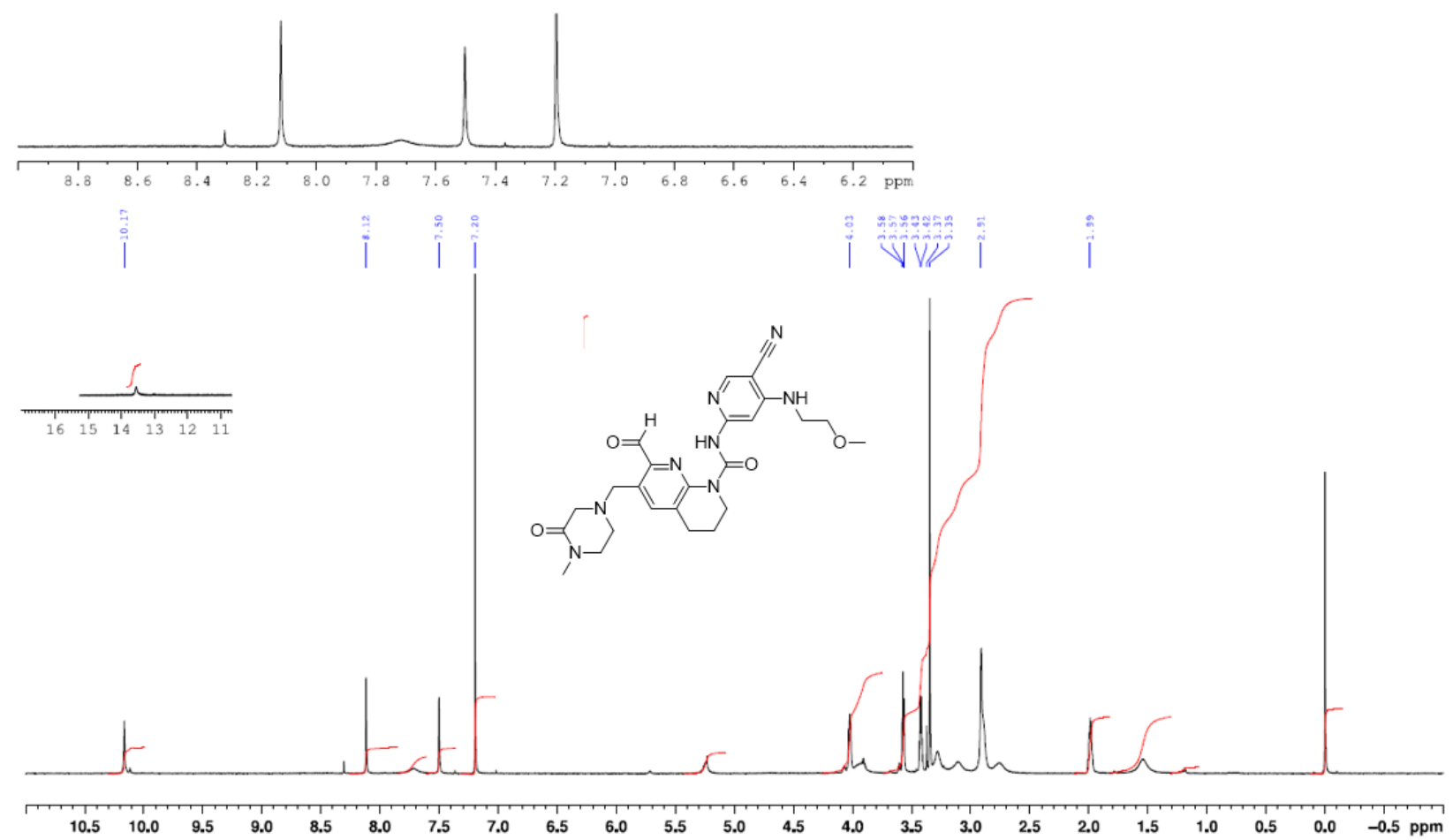


$400 \mathrm{MHz}{ }^{1} \mathrm{H},{ }^{13} \mathrm{C}$ HSQC NMR in DMSO- $d_{6}$ of $N$-(5-cyano-4-((2-methoxyethyl)amino)pyridin-2-yl)-6-(((3R,5S)-3,5dimethylpiperazin-1-yl)methyl)-7-formyl-3,4-dihydro-1,8-naphthyridine-1 $(2 H)$-carboxamide 86
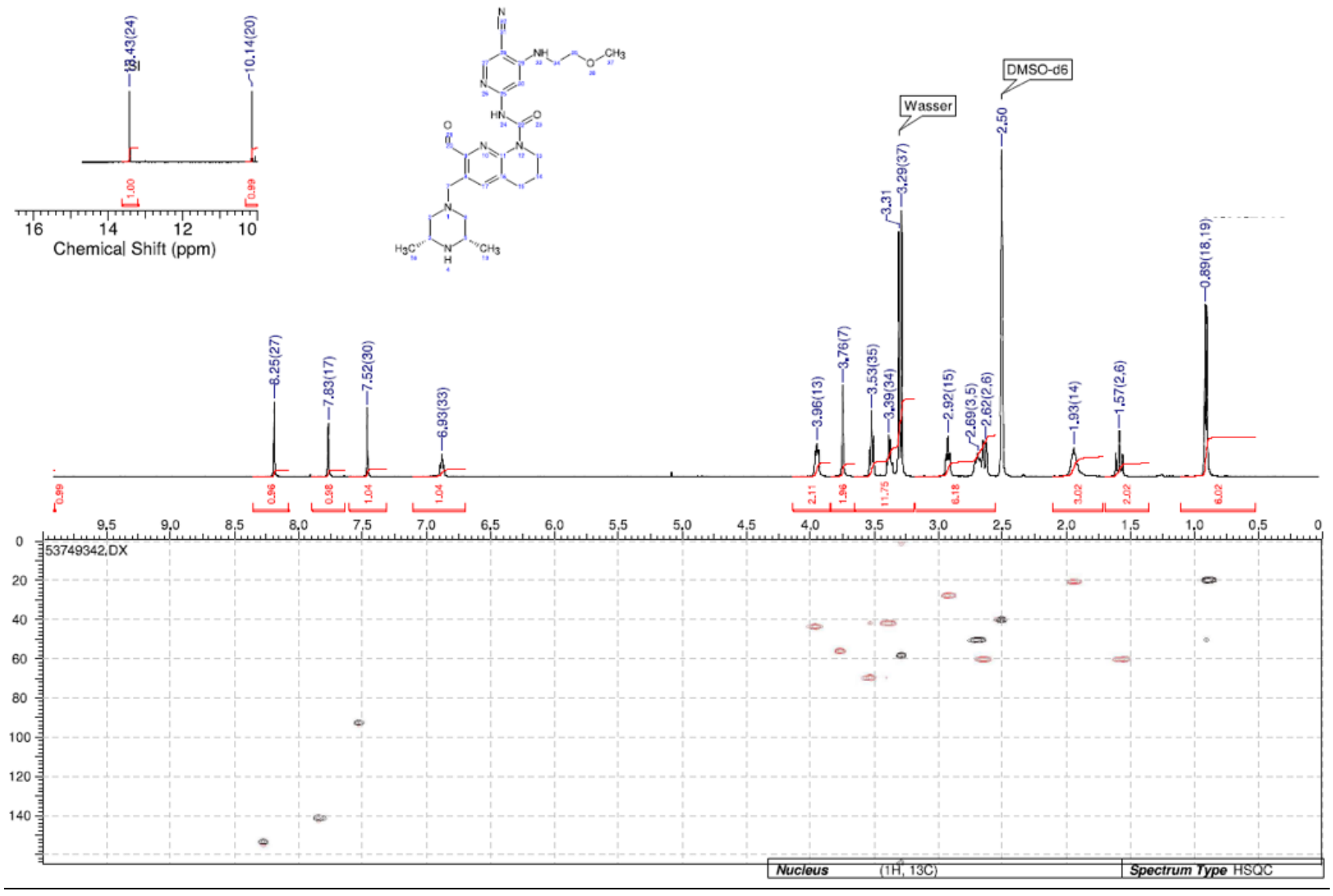
$400 \mathrm{MHz}{ }^{1} \mathrm{H}$ NMR in DMSO- $d_{6}$ of $N$-(5-cyano-4-((2-methoxyethyl)amino)pyridin-2-yl)-7-formyl-6-((3,3,4trimethyl-2-oxopiperazin-1-yl)methyl)-3,4-dihydro-1,8-naphthyridine-1(2H)-carboxamide 87
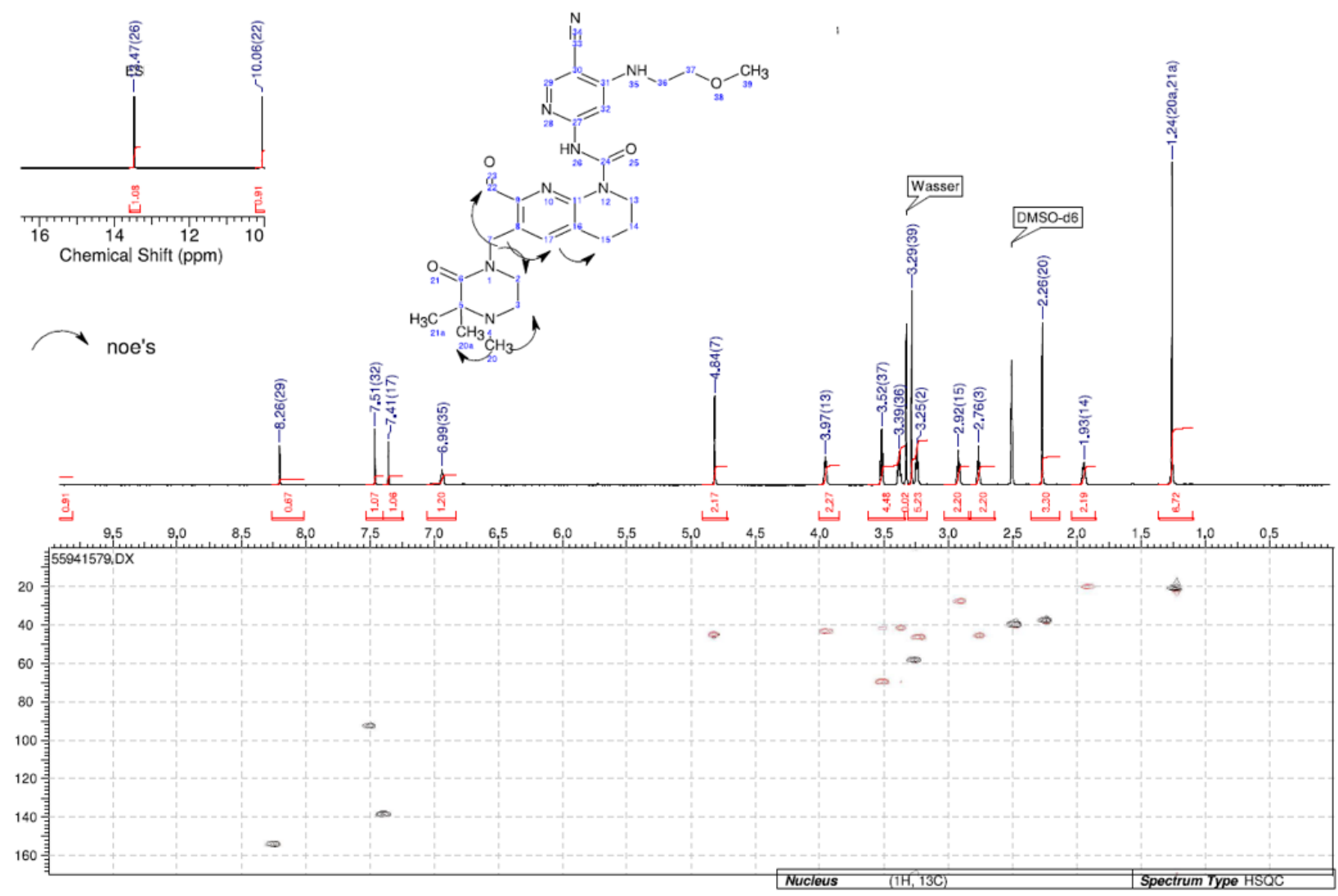
$600 \mathrm{MHz}{ }^{1} \mathrm{H},{ }^{13} \mathrm{C}$ HSQC NMR in DMSO- $d_{6}$ of $N$-(5-cyano-4-((2-methoxyethyl)amino)pyridin-2-yl)-7-formyl-6((2,2,4-trimethyl-6-oxopiperazin-1-yl)methyl)-3,4-dihydro-1,8-naphthyridine-1(2H)-carboxamide 88
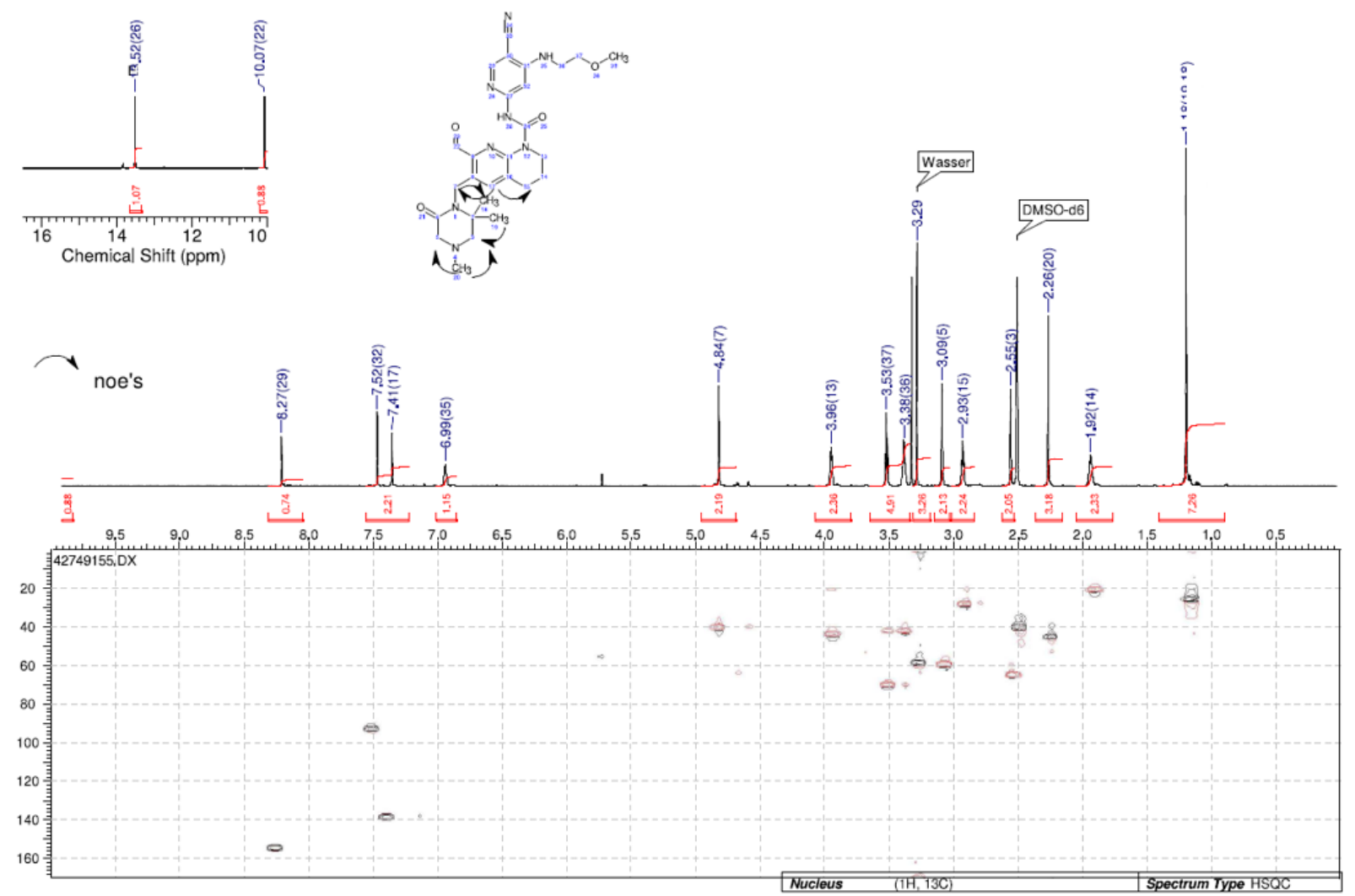
$600 \mathrm{MHz}{ }^{1} \mathrm{H}$ NMR in DMSO- $d_{6}$ of $(S)$ - and (R)- $N$-(5-cyano-4-((1-methoxypropan-2-yl)amino)pyridin-2-yl)-7formyl-6-((4-methyl-2-oxopiperazin-1-yl)methyl)-3,4-dihydro-1,8-naphthyridine-1(2H)-carboxamide 89 and 90

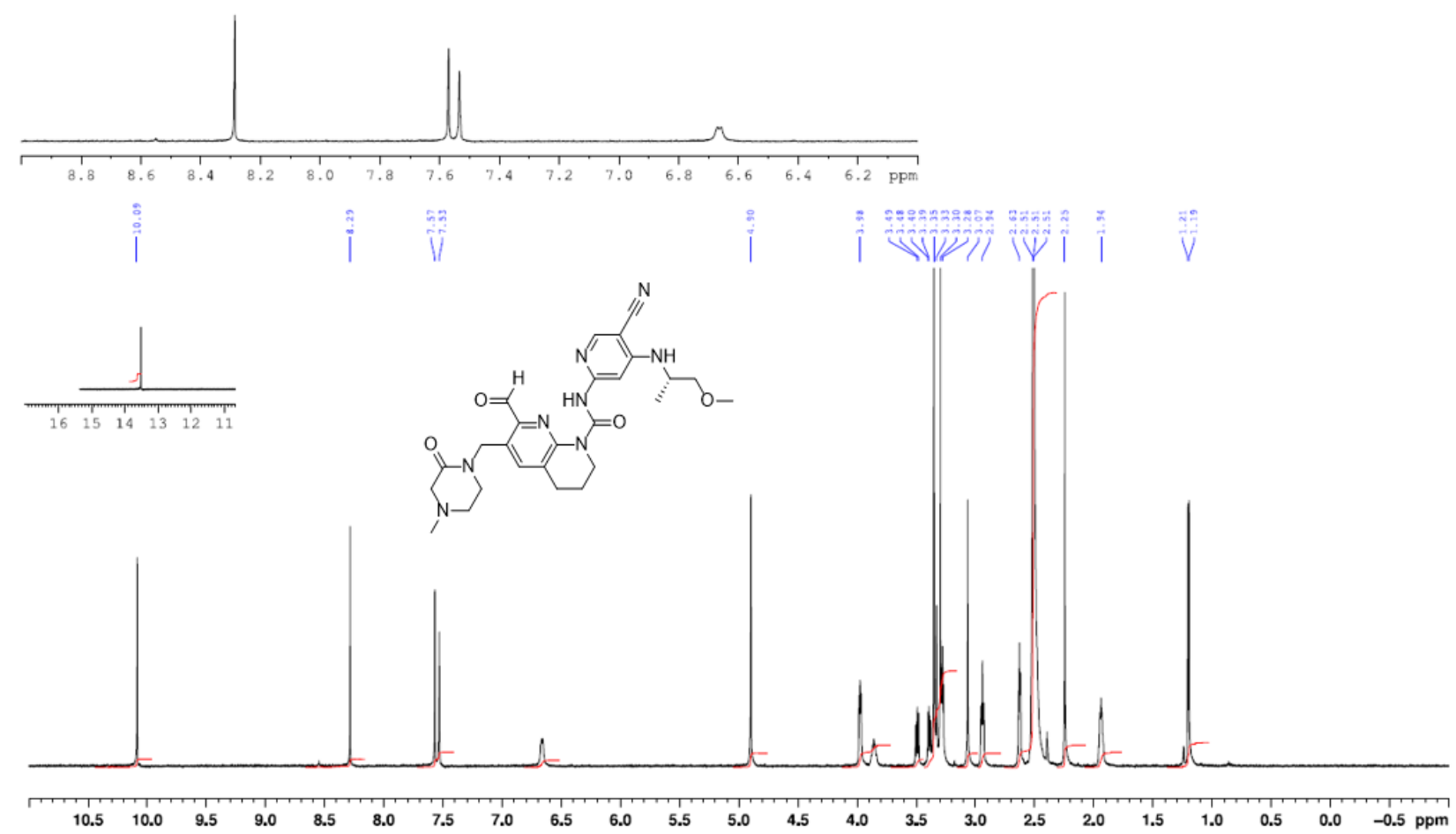


$400 \mathrm{MHz}{ }^{1} \mathrm{H}$ NMR in DMSO-d 6 of 3-(5-cyano-4-((2-methoxyethyl)amino)pyridin-2-yl)-1-(6-formyl-5-((4-methyl2-oxopiperazin-1-yl)methyl)pyridin-2-yl)-1-methylurea 91

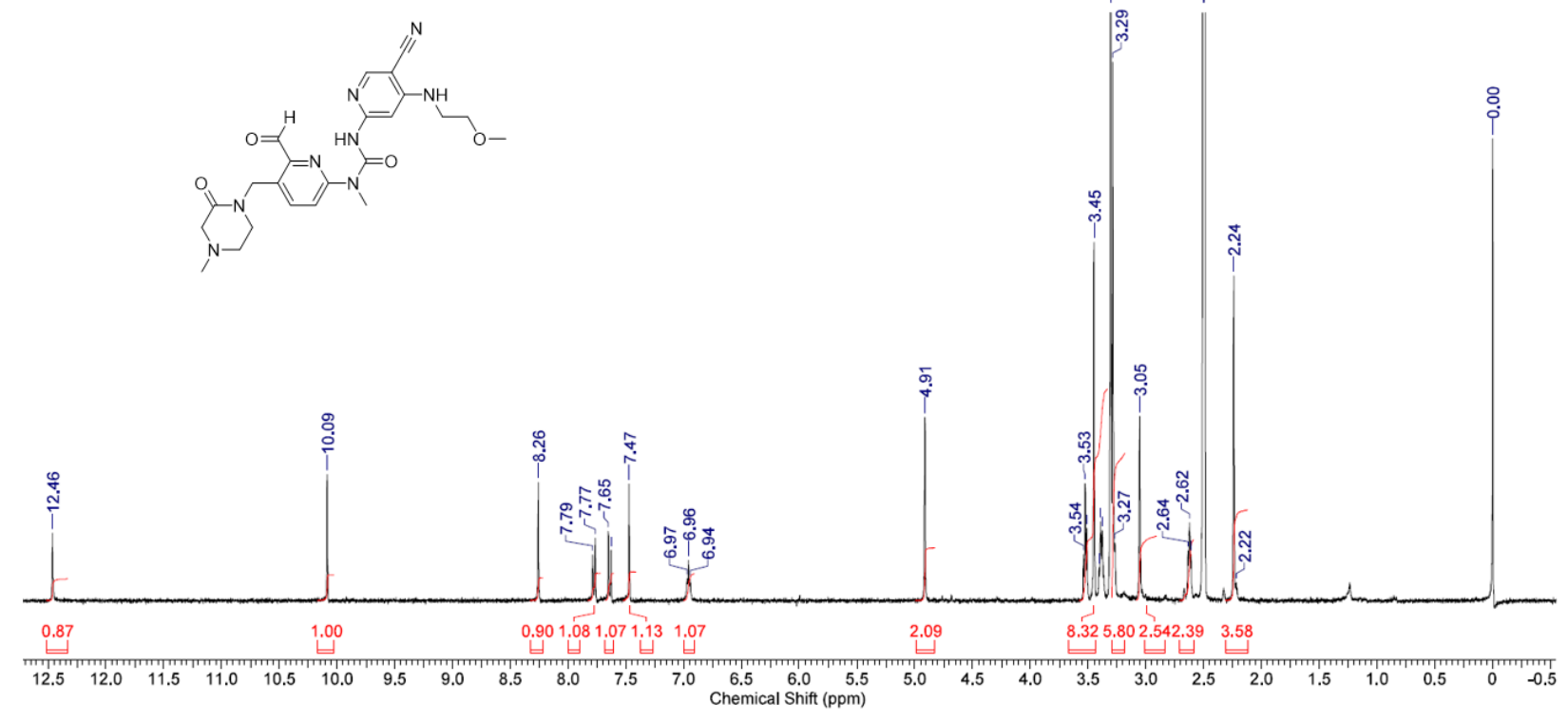




\section{Cocrystal structure of compound 84 in complex with the FGFR4 kinase domain}

\section{Protein Production, Crystallization and Structure Determination.}

Expression and purification of human FGFR4K was performed as described ${ }^{\mathrm{S} 13}$. The crystal used for solving the structure was grown by mixing $0.5 \mu \mathrm{l}$ of protein solution $(13 \mathrm{mg} / \mathrm{ml}$ in $50 \mathrm{mM} \mathrm{HEPES} \mathrm{pH} 8.0,100 \mathrm{mM} \mathrm{NaCl}, 3 \%$ glycerol, $1 \mathrm{mM}$ TCEP and $2 \mathrm{mM}$ roblitinib incubated for $1 \mathrm{~h}$ on ice) with $0.5 \mu \mathrm{l}$ of reservoir solution (13.5\% w/v PEG 3350, 0.1 $\left.\mathrm{M}\left(\mathrm{NH}_{4}\right)_{2} \mathrm{SO}_{4}, 0.1 \mathrm{M} \mathrm{NaAc} \mathrm{pH} 4.25\right)$ using the hanging drop vapour diffusion method at $277 \mathrm{~K}$. Before flash freezing in liquid nitrogen the crystal was cryo protected by the addition of 2-methyl-2,4-pentanediol directly to the crystallization drop to a final concentration of $25 \%(\mathrm{v} / \mathrm{v})$.

The X-ray diffraction data were collected at the SWISS LIGHT SOURCE (SLS, Villigen, Switzerland) using cryogenic conditions. The diffraction data were processed and scaled with XDS and XSCALE ${ }^{\text {S14 }}$, respectively. The structure was solved by molecular replacement using the coordinates of hFGFR4K deposited at the Protein Data Bank (PDB code 4TYG). Subsequent model building and refinement was performed according to standard protocols with the software packages $C C P 4^{\mathrm{S} 15}$ and $C O O T^{\mathrm{S} 16}$. The final refinement cycle was done with BUSTER ${ }^{\mathrm{S} 17}$.

Table S4 Data collection and Refinement Statistics

\begin{tabular}{|c|c|}
\hline & FGFR4 - roblitinib \\
\hline & Crystal Parameter \\
\hline Space group & $\mathrm{P} 2{ }_{1} 2{ }_{1}{ }_{1}$ \\
\hline cell dimensions & $a=183.7 \AA, b 67.2 \AA, c=53.1 \AA$ \\
\hline \multirow[t]{2}{*}{ molecules per $\mathrm{AU}^{a}$} & 2 \\
\hline & Data Collection \\
\hline beamline & SLS, X06SA \\
\hline wavelength $(\AA)$ & 1.0000 \\
\hline resolution range $(\AA)^{b}$ & $50.0-2.13(2.23-2.13)$ \\
\hline observed/unique ${ }^{c}$ reflections & $155994 / 37439$ \\
\hline completeness $(\%)^{b}$ & $99.3(97.3)$ \\
\hline$R_{\text {merge }}(\%)^{b, c}$ & $4.8(44.5)$ \\
\hline$I / \sigma(I)^{b}$ & $19.0(3.9)$ \\
\hline \multirow[t]{2}{*}{ redundancy ${ }^{b}$} & $4.2(4.0)$ \\
\hline & refinement \\
\hline resolution ( & $46.0-2.13$ \\
\hline$R_{\mathrm{work} /} R_{\mathrm{free}}{ }^{d}$ & $19.6 / 23.1$ \\
\hline \multicolumn{2}{|l|}{ no. atoms } \\
\hline Protein & 4318 \\
\hline heterogen & 99 \\
\hline Water & 238 \\
\hline
\end{tabular}




\begin{tabular}{ll}
\hline $\begin{array}{l}\text { B-factors } \\
\text { r.m.s deviations }{ }^{e}\end{array}$ & 41.0 \\
bond lengths $(\AA)$ & 0.010 \\
$\quad$ bond angles $\left({ }^{\circ}\right)$ & 1.03 \\
Ramachandran $(\%)^{f}$ & $96.6 / 3.0 / 0.4$ \\
PDB accession code & 6 YI 8 \\
\hline
\end{tabular}

${ }^{a}$ Asymmetric unit. ${ }^{b}$ Values in parentheses of resolution range, completeness, $R_{\text {sym, }}$, and $I / \sigma(I)$ correspond to the last resolution shell. ${ }^{c} \mathrm{R}_{\operatorname{merge}}(\mathrm{I})=\Sigma_{\mathrm{hk}} \Sigma_{\mathrm{j}} \mid\left[\mathrm{I}(\mathrm{hkl})_{\mathrm{j}}-\mathrm{I}(\mathrm{hkl})\right] / \Sigma_{\mathrm{hkl}} \mathrm{Ihkl}$, where $\mathrm{I}(\mathrm{hkl})_{\mathrm{j}}$ is the measurement of the intensity of reflection $\mathrm{hkl}$ and $\langle\mathrm{I}(\mathrm{hkl})\rangle$ is the average intensity. ${ }^{d} \mathrm{R}=\Sigma_{\mathrm{hk}} \| \mathrm{F}_{\mathrm{obs}}|-| \mathrm{F}_{\mathrm{cal}}|| / \Sigma_{\mathrm{hk}}\left|\mathrm{F}_{\mathrm{obs}}\right|$, where $\mathrm{R}_{\text {free }}$ is calculated without a $\sigma$ cutoff for a randomly chosen $5 \%$ of reflections, which were not used for structure refinement, and $\mathrm{R}_{\text {work }}$ is calculated for the remaining reflections. ${ }^{e}$ Root mean square deviations from ideal bond lengths/angles. ${ }^{f}$ Number of residues in favored region/allowed region/outlier region. 


\section{Single crystal X-ray structure of compound 84}

Crystalisation: Crystals suitable for diffraction experiments were obtained from amorphous $\mathbf{8 4}$ by slow evaporation of a solution in acetonitrile and water. Under these conditions compound $\mathbf{8 4}$ crystallised as a mono-hydrate.

Data collection: Intensity data were collected at $100 \mathrm{~K}$ on a Bruker AXS three-circle diffractometer with monochromated $\mathrm{Cu}\left(\mathrm{K}_{\alpha}\right)$-radiation (Helios $\mathrm{MX}$ confocal mirror monochromator), microfocus rotating anode generator, and a Smart $6000 \mathrm{CCD}$ detector using the SMART software. ${ }^{\mathrm{S} 18} 15 \omega$-scans at different $\Phi$-positions were performed to ensure appropriate data redundancy (9.8). Collected intensity data showed radiation damage occurred during data collection. Therefore for structure solution and refinement only data of the first 11 scans were used (data redundancy 7.4). Data processing and global cell refinement were performed with Saint. ${ }^{S 19} \mathrm{~A}$ semi-empirical absorption correction was applied, based on the intensities of symmetry-related reflections measured at different angular settings including correction for crystal decomposition. ${ }^{520}$ Crystal data, data collection parameters, and convergence results are listed in Table S5.

Structure solution and refinement: The structure was solved by dual space-recycling methods and subsequent DF syntheses and refined based on full-matrix least-squares on F2 using the SHELXTL program suite. ${ }^{\text {S21 }}$ Anisotropic displacement parameters were used for all non-hydrogen atoms. Hydrogen atoms were located in DF maps and refined in idealized positions using a riding model.

Results: Crystal data and refinement results are compiled in Table S5, and the final atomic coordinates are listed in Table S6 and Table S7. Figure S1 shows a perspective view of compound $\mathbf{8 4}$ in the crystal along with the numbering scheme adopted. Within the limits of accuracy all bond lengths in the structure (Table S8) agree with expected values. ${ }^{\text {S22 }}$ Further geometry details are given in Table S9, Table S10, and Table S11. Compound $\mathbf{8 4}$ crystallises from a mixture of acetonitrile and water with 1 equivalent of water as a monohydrate. A listing of the intramolecular and intermolecular hydrogen bonding network in the crystal structure of compound $\mathbf{8 4}$ is given in Table S12.

Deposition: Crystallographic data (excluding structure factors) have been deposited with the Cambridge Crystallographic Data Centre as supplementary publication number CCDC 2009566. Copies of the data can be obtained free of charge on application to CCDC, 12 Union Road, Cambridge CB2 1EZ, UK [fax (+44) 1223336033 , email:deposit@ccdc.cam.ac.uk].

This material is available free of charge via the internet at http://pubs.acs.org. 
Figure S1 Structure of compound 84 in the crystal with the atomic numbering

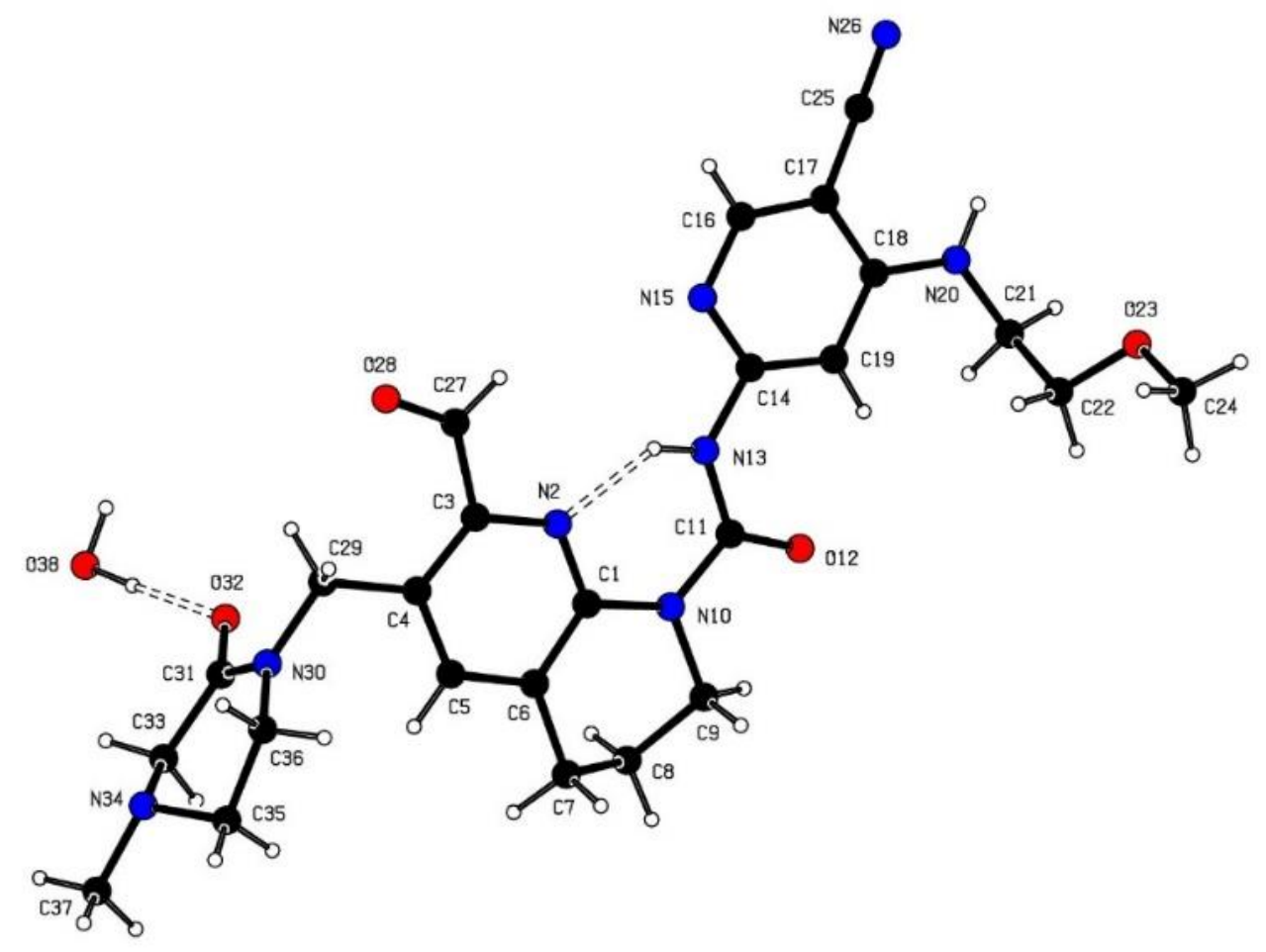

Representation created with PLATON. ${ }^{\text {S23 }}$ All atomic radii are arbitrary. Hydrogen bonds are shown as dotted lines. 
Table S5 Crystal data and refinement results for compound $\mathbf{8 4}$

Empirical formula

Formula weight

Temperature

Wavelength

Crystal system

Space group

Unit cell dimensions

Volume

Z

Density (calculated)

Absorption coefficient

$\mathrm{F}(000)$

Crystal size

Theta range for data collection

Index ranges

Reflections collected

Independent reflections

Completeness to theta $=66.59^{\circ}$

Absorption correction

Max. and min. transmission

Refinement method

Data / restraints / parameters

Goodness-of-fit on $\mathrm{F}^{2}$

Final $\mathrm{R}$ indices $[\mathrm{I}>2 \operatorname{sigma}(\mathrm{I})]$

$\mathrm{R}$ indices (all data)

Extinction coefficient

Largest diff. peak and hole
$\mathrm{C}_{25} \mathrm{H}_{32} \mathrm{~N}_{8} \mathrm{O}_{5}$

524.59

100(2) K

$1.54178 \AA$

Monoclinic

$\mathrm{C} 2 / \mathrm{c}$

$\mathrm{a}=39.79(2) \AA$

$\alpha=90^{\circ}$

$\mathrm{b}=7.071(4) \AA$

$\beta=100.74(4)^{\circ}$

$\mathrm{c}=18.322(11) \AA$

$\gamma=90^{\circ}$

5064(5) $\AA^{3}$

8

$1.376 \mathrm{~g} / \mathrm{cm}^{3}$

$0.817 \mathrm{~mm}^{-1}$

2224

$0.12 \times 0.04 \times 0.02 \mathrm{~mm}^{3}$

2.26 to $66.59^{\circ}$

$-47<=\mathrm{h}<=47,-8<=\mathrm{k}<=8,-20<=\mathrm{l}<=21$

34504

$4417[\mathrm{R}(\mathrm{int})=0.0901]$

$98.6 \%$

Semi-empirical from equivalents

0.9838 and 0.9083

Full-matrix least-squares on $\mathrm{F}^{2}$

4417 / 0 / 346

1.024

$\mathrm{R}_{1}=0.0509, \mathrm{wR}_{2}=0.1207$

$\mathrm{R}_{1}=0.0735, \mathrm{wR}_{2}=0.1332$

$0.00050(5)$

0.41 and -0.29 e. $\AA^{-3}$ 
Table S6 Atomic coordinates and equivalent isotropic displacement parameters for compound 84

\begin{tabular}{|c|c|c|c|c|}
\hline atom & $\mathrm{x}$ & $\mathrm{y}$ & $\mathrm{Z}$ & $\mathrm{U}(\mathrm{eq})$ \\
\hline $\mathrm{C} 1$ & $0.80517(6)$ & $0.9719(3)$ & $0.85826(12)$ & $0.0174(5)$ \\
\hline $\mathrm{N} 2$ & $0.80721(5)$ & $1.0258(3)$ & $0.92837(10)$ & $0.0190(4)$ \\
\hline $\mathrm{C} 3$ & $0.83738(6)$ & $1.0838(3)$ & $0.96876(12)$ & $0.0194(5)$ \\
\hline $\mathrm{C} 4$ & $0.86770(6)$ & $1.0892(3)$ & $0.94121(12)$ & $0.0204(5)$ \\
\hline $\mathrm{C} 5$ & $0.86461(6)$ & $1.0367(3)$ & $0.86708(13)$ & $0.0212(5)$ \\
\hline C6 & $0.83420(6)$ & $0.9798(3)$ & $0.82378(12)$ & $0.0194(5)$ \\
\hline $\mathrm{C} 7$ & $0.83237(6)$ & $0.9188(4)$ & $0.74496(12)$ & $0.0244(5)$ \\
\hline $\mathrm{C} 8$ & $0.80488(6)$ & $0.7690(3)$ & $0.72528(13)$ & $0.0227(5)$ \\
\hline C9 & $0.77137(6)$ & $0.8462(3)$ & $0.74013(12)$ & $0.0226(5)$ \\
\hline N10 & $0.77358(5)$ & $0.9012(3)$ & $0.81930(10)$ & $0.0185(4)$ \\
\hline $\mathrm{C} 11$ & $0.74253(6)$ & $0.8822(3)$ & $0.84548(12)$ & $0.0198(5)$ \\
\hline $\mathrm{O} 12$ & $0.71752(4)$ & $0.8168(2)$ & $0.80434(9)$ & $0.0249(4)$ \\
\hline N13 & $0.74279(5)$ & $0.9408(3)$ & $0.91647(10)$ & $0.0214(4)$ \\
\hline $\mathrm{C} 14$ & $0.71591(6)$ & $0.9326(3)$ & $0.95574(12)$ & $0.0205(5)$ \\
\hline N15 & $0.72597(5)$ & $0.9929(3)$ & $1.02661(10)$ & $0.0219(4)$ \\
\hline $\mathrm{C} 16$ & $0.70186(6)$ & $0.9909(3)$ & $1.06802(13)$ & $0.0220(5)$ \\
\hline $\mathrm{C} 17$ & $0.66819(6)$ & $0.9333(3)$ & $1.04386(12)$ & $0.0208(5)$ \\
\hline $\mathrm{C} 18$ & $0.65795(6)$ & $0.8714(3)$ & $0.96936(12)$ & $0.0195(5)$ \\
\hline C19 & $0.68319(6)$ & $0.8723(3)$ & $0.92526(13)$ & $0.0211(5)$ \\
\hline N20 & $0.62536(5)$ & $0.8154(3)$ & $0.94290(10)$ & $0.0232(4)$ \\
\hline $\mathrm{C} 21$ & $0.61368(6)$ & $0.7527(4)$ & $0.86682(13)$ & $0.0248(5)$ \\
\hline $\mathrm{C} 22$ & $0.60744(7)$ & $0.9104(4)$ & $0.81017(14)$ & $0.0293(6)$ \\
\hline $\mathrm{O} 23$ & $0.57575(5)$ & $0.9962(3)$ & $0.81359(11)$ & $0.0452(5)$ \\
\hline $\mathrm{C} 24$ & $0.56987(10)$ & $1.1569(6)$ & $0.7663(2)$ & $0.0619(10)$ \\
\hline $\mathrm{C} 25$ & $0.64461(6)$ & $0.9417(3)$ & $1.09396(13)$ & $0.0220(5)$ \\
\hline N26 & $0.62583(6)$ & $0.9485(3)$ & $1.13476(12)$ & $0.0303(5)$ \\
\hline $\mathrm{C} 27$ & $0.83430(6)$ & $1.1367(3)$ & $1.04534(12)$ & $0.0223(5)$ \\
\hline $\mathrm{O} 28$ & $0.85758(4)$ & $1.1940(2)$ & $1.09267(9)$ & $0.0268(4)$ \\
\hline $\mathrm{C} 29$ & $0.90189(6)$ & $1.1436(4)$ & $0.98833(13)$ & $0.0238(5)$ \\
\hline N30 & $0.93084(5)$ & $1.0991(3)$ & $0.95223(11)$ & $0.0267(5)$ \\
\hline C31 & $0.94410(6)$ & $0.9233(4)$ & $0.95898(13)$ & $0.0274(6)$ \\
\hline $\mathrm{O} 32$ & $0.93203(4)$ & $0.7964(3)$ & $0.99287(10)$ & $0.0312(4)$ \\
\hline C33 & $0.97390(7)$ & $0.8777(4)$ & $0.92218(15)$ & $0.0337(6)$ \\
\hline N34 & $0.99161(6)$ & $1.0434(4)$ & $0.90191(12)$ & $0.0362(6)$ \\
\hline C35 & $0.96697(7)$ & $1.1727(5)$ & $0.86086(16)$ & $0.0416(7)$ \\
\hline C36 & $0.94475(7)$ & $1.2506(4)$ & $0.91221(16)$ & $0.0361(6)$ \\
\hline C37 & $1.01747(7)$ & $0.9862(5)$ & $0.85951(16)$ & $0.0457(8)$ \\
\hline O38 & $0.96777(7)$ & $0.4979(3)$ & $1.07984(15)$ & $0.0652(7)$ \\
\hline
\end{tabular}

$\mathrm{U}(\mathrm{eq})$ is defined as one third of the trace of the orthogonalized Uij tensor. Isotropic displacement parameters in $\AA^{2}$. 
Table S7 Hydrogen atom coordinates and equivalent isotropic displacement parameters for compound 84

\begin{tabular}{|c|c|c|c|c|}
\hline atom & $\mathrm{x}$ & $\mathrm{y}$ & $\mathrm{Z}$ & $\mathrm{U}(\mathrm{eq})$ \\
\hline H5 & 0.8845 & 1.0404 & 0.8452 & 0.025 \\
\hline H7A & 0.8548 & 0.8671 & 0.7385 & 0.029 \\
\hline H7B & 0.8270 & 1.0289 & 0.7114 & 0.029 \\
\hline H8A & 0.8025 & 0.7342 & 0.6722 & 0.027 \\
\hline H8B & 0.8113 & 0.6541 & 0.7556 & 0.027 \\
\hline H9A & 0.7647 & 0.9580 & 0.7082 & 0.027 \\
\hline H9B & 0.7533 & 0.7492 & 0.7269 & 0.027 \\
\hline H13 & 0.7621 & 0.9895 & 0.9403 & 0.026 \\
\hline H16 & 0.7081 & 1.0321 & 1.1181 & 0.026 \\
\hline H19 & 0.6779 & 0.8319 & 0.8750 & 0.025 \\
\hline $\mathrm{H} 20$ & 0.6106 & 0.8172 & 0.9732 & 0.028 \\
\hline $\mathrm{H} 21 \mathrm{~A}$ & 0.5922 & 0.6805 & 0.8644 & 0.030 \\
\hline $\mathrm{H} 21 \mathrm{~B}$ & 0.6310 & 0.6654 & 0.8532 & 0.030 \\
\hline $\mathrm{H} 22 \mathrm{~A}$ & 0.6260 & 1.0051 & 0.8209 & 0.035 \\
\hline $\mathrm{H} 22 \mathrm{~B}$ & 0.6071 & 0.8589 & 0.7598 & 0.035 \\
\hline $\mathrm{H} 24 \mathrm{~A}$ & 0.5730 & 1.1219 & 0.7163 & 0.093 \\
\hline H24B & 0.5861 & 1.2571 & 0.7858 & 0.093 \\
\hline $\mathrm{H} 24 \mathrm{C}$ & 0.5464 & 1.2024 & 0.7642 & 0.093 \\
\hline $\mathrm{H} 27$ & 0.8124 & 1.1249 & 1.0585 & 0.027 \\
\hline H29A & 0.9019 & 1.2809 & 0.9988 & 0.029 \\
\hline H29B & 0.9048 & 1.0758 & 1.0364 & 0.029 \\
\hline H33A & 0.9904 & 0.7985 & 0.9563 & 0.040 \\
\hline H33B & 0.9656 & 0.8023 & 0.8769 & 0.040 \\
\hline $\mathrm{H} 35 \mathrm{~A}$ & 0.9526 & 1.1059 & 0.8188 & 0.050 \\
\hline H35B & 0.9790 & 1.2775 & 0.8406 & 0.050 \\
\hline H36A & 0.9584 & 1.3376 & 0.9484 & 0.043 \\
\hline H36B & 0.9257 & 1.3238 & 0.8829 & 0.043 \\
\hline H37A & 1.0292 & 1.0985 & 0.8455 & 0.069 \\
\hline H37B & 1.0065 & 0.9189 & 0.8146 & 0.069 \\
\hline $\mathrm{H} 37 \mathrm{C}$ & 1.0341 & 0.9026 & 0.8899 & 0.069 \\
\hline H38B & 0.9531 & 0.4978 & 1.1118 & 0.098 \\
\hline H38A & 0.9556 & 0.5815 & 1.0485 & 0.098 \\
\hline
\end{tabular}

$\mathrm{U}(\mathrm{eq})$ is defined as one third of the trace of the orthogonalized Uij tensor. Isotropic displacement parameters in $\AA^{2}$. Estimated standard deviations of refined parameters given in parentheses. 
Table S8 Bond angles for compound 84

\begin{tabular}{|c|c|c|c|}
\hline atoms & angle & atoms & angle \\
\hline N2-C1-N10 & $118.50(19)$ & N20-C21-H21A & 108.6 \\
\hline N2-C1-C6 & $120.8(2)$ & $\mathrm{C} 22-\mathrm{C} 21-\mathrm{H} 21 \mathrm{~A}$ & 108.6 \\
\hline N10-C1-C6 & $120.67(19)$ & N20-C21-H21B & 108.6 \\
\hline $\mathrm{C} 1-\mathrm{N} 2-\mathrm{C} 3$ & $120.3(2)$ & $\mathrm{C} 22-\mathrm{C} 21-\mathrm{H} 21 \mathrm{~B}$ & 108.6 \\
\hline $\mathrm{N} 2-\mathrm{C} 3-\mathrm{C} 4$ & $123.4(2)$ & $\mathrm{H} 21 \mathrm{~A}-\mathrm{C} 21-\mathrm{H} 21 \mathrm{~B}$ & 107.6 \\
\hline N2-C3-C27 & $112.0(2)$ & $\mathrm{O} 23-\mathrm{C} 22-\mathrm{C} 21$ & $108.7(2)$ \\
\hline $\mathrm{C} 4-\mathrm{C} 3-\mathrm{C} 27$ & $124.6(2)$ & $\mathrm{O} 23-\mathrm{C} 22-\mathrm{H} 22 \mathrm{~A}$ & 110.0 \\
\hline C5-C4-C3 & $114.9(2)$ & C21-C22-H22A & 110.0 \\
\hline C5-C4-C29 & $122.0(2)$ & $\mathrm{O} 23-\mathrm{C} 22-\mathrm{H} 22 \mathrm{~B}$ & 110.0 \\
\hline C3-C4-C29 & $123.1(2)$ & $\mathrm{C} 21-\mathrm{C} 22-\mathrm{H} 22 \mathrm{~B}$ & 110.0 \\
\hline C6-C5-C4 & $123.3(2)$ & $\mathrm{H} 22 \mathrm{~A}-\mathrm{C} 22-\mathrm{H} 22 \mathrm{~B}$ & 108.3 \\
\hline C6-C5-H5 & 118.4 & $\mathrm{C} 22-\mathrm{O} 23-\mathrm{C} 24$ & $111.3(2)$ \\
\hline C4-C5-H5 & 118.4 & $\mathrm{O} 23-\mathrm{C} 24-\mathrm{H} 24 \mathrm{~A}$ & 109.5 \\
\hline $\mathrm{C} 5-\mathrm{C} 6-\mathrm{C} 1$ & $117.1(2)$ & $\mathrm{O} 23-\mathrm{C} 24-\mathrm{H} 24 \mathrm{~B}$ & 109.5 \\
\hline $\mathrm{C} 5-\mathrm{C} 6-\mathrm{C} 7$ & $121.3(2)$ & $\mathrm{H} 24 \mathrm{~A}-\mathrm{C} 24-\mathrm{H} 24 \mathrm{~B}$ & 109.5 \\
\hline $\mathrm{C} 1-\mathrm{C} 6-\mathrm{C} 7$ & $121.5(2)$ & $\mathrm{O} 23-\mathrm{C} 24-\mathrm{H} 24 \mathrm{C}$ & 109.5 \\
\hline C6-C7-C8 & 109.51(19) & $\mathrm{H} 24 \mathrm{~A}-\mathrm{C} 24-\mathrm{H} 24 \mathrm{C}$ & 109.5 \\
\hline C6-C7-H7A & 109.8 & $\mathrm{H} 24 \mathrm{~B}-\mathrm{C} 24-\mathrm{H} 24 \mathrm{C}$ & 109.5 \\
\hline C8-C7-H7A & 109.8 & N26-C25-C17 & $179.5(3)$ \\
\hline C6-C7-H7B & 109.8 & $\mathrm{O} 28-\mathrm{C} 27-\mathrm{C} 3$ & $125.1(2)$ \\
\hline C8-C7-H7B & 109.8 & $\mathrm{O} 28-\mathrm{C} 27-\mathrm{H} 27$ & 117.5 \\
\hline H7A-C7-H7B & 108.2 & C3-C27-H27 & 117.5 \\
\hline C9-C8-C7 & $109.0(2)$ & N30-C29-C4 & $112.66(19)$ \\
\hline C9-C8-H8A & 109.9 & N30-C29-H29A & 109.1 \\
\hline C7-C8-H8A & 109.9 & C4-C29-H29A & 109.1 \\
\hline C9-C8-H8B & 109.9 & N30-C29-H29B & 109.1 \\
\hline C7-C8-H8B & 109.9 & C4-C29-H29B & 109.1 \\
\hline H8A-C8-H8B & 108.3 & H29A-C29-H29B & 107.8 \\
\hline N10-C9-C8 & $112.08(19)$ & C31-N30-C36 & $122.9(2)$ \\
\hline N10-C9-H9A & 109.2 & C31-N30-C29 & $118.9(2)$ \\
\hline C8-C9-H9A & 109.2 & $\mathrm{C} 36-\mathrm{N} 30-\mathrm{C} 29$ & $118.1(2)$ \\
\hline N10-C9-H9B & 109.2 & O32-C31-N30 & $122.2(2)$ \\
\hline С8-С9-Н9B & 109.2 & O32-C31-C33 & $118.8(2)$ \\
\hline H9A-C9-H9B & 107.9 & N30-C31-C33 & $119.0(2)$ \\
\hline C11-N10-C1 & $127.81(18)$ & N34-C33-C31 & $113.7(2)$ \\
\hline C11-N10-C9 & $114.16(18)$ & N34-C33-H33A & 108.8 \\
\hline C1-N10-C9 & $117.98(18)$ & C31-C33-H33A & 108.8 \\
\hline O12-C11-N13 & $124.3(2)$ & N34-C33-H33B & 108.8 \\
\hline $\mathrm{O} 12-\mathrm{C} 11-\mathrm{N} 10$ & $119.3(2)$ & C31-C33-H33B & 108.8 \\
\hline N13-C11-N10 & $116.3(2)$ & H33A-C33-H33B & 107.7 \\
\hline
\end{tabular}




\begin{tabular}{|c|c|c|c|}
\hline atoms & angle & atoms & angle \\
\hline N2-C1-N10 & $118.50(19)$ & N20-C21-H21A & 108.6 \\
\hline C11-N13-C14 & $127.5(2)$ & C35-N34-C33 & $109.3(2)$ \\
\hline C11-N13-H13 & 116.3 & C35-N34-C37 & $112.1(2)$ \\
\hline C14-N13-H13 & 116.3 & C33-N34-C37 & $109.7(2)$ \\
\hline N15-C14-C19 & $124.8(2)$ & N34-C35-C36 & $109.0(2)$ \\
\hline N15-C14-N13 & $111.3(2)$ & N34-C35-H35A & 109.9 \\
\hline C19-C14-N13 & $123.9(2)$ & C36-C35-H35A & 109.9 \\
\hline C16-N15-C14 & $115.3(2)$ & N34-C35-H35B & 109.9 \\
\hline N15-C16-C17 & $125.2(2)$ & C36-C35-H35B & 109.9 \\
\hline N15-C16-H16 & 117.4 & H35 A-C35-H35B & 108.3 \\
\hline C17-C16-H16 & 117.4 & N30-C36-C35 & $111.4(2)$ \\
\hline C16-C17-C18 & $118.9(2)$ & N30-C36-H36A & 109.3 \\
\hline C16-C17-C25 & $119.4(2)$ & C35-C36-H36A & 109.3 \\
\hline C18-C17-C25 & $121.6(2)$ & N30-C36-H36B & 109.3 \\
\hline N20-C18-C19 & $122.4(2)$ & С $35-\mathrm{C} 36-\mathrm{H} 36 \mathrm{~B}$ & 109.3 \\
\hline N20-C18-C17 & $121.2(2)$ & H36A-C36-H36B & 108.0 \\
\hline C19-C18-C17 & $116.4(2)$ & N34-C37-H37A & 109.5 \\
\hline C14-C19-C18 & $119.3(2)$ & N34-C37-H37B & 109.5 \\
\hline C14-C19-H19 & 120.3 & H37A-C37-H37B & 109.5 \\
\hline C18-C19-H19 & 120.3 & N34-C37-H37C & 109.5 \\
\hline C18-N20-C21 & 123.03(19) & H37A-C37-H37C & 109.5 \\
\hline C18-N20-H20 & 118.5 & H37B-C37-H37C & 109.5 \\
\hline $\mathrm{C} 21-\mathrm{N} 20-\mathrm{H} 20$ & 118.5 & H38B-O38-H38A & 94.5 \\
\hline N20-C21-C22 & $114.5(2)$ & & \\
\hline
\end{tabular}

Bond angles in ${ }^{\circ}$. Estimated standard deviations of refined parameters given in parentheses. Symmetry transformations used to generate equivalent atoms: n.a. 
Table S9 Bond lengths for compound 84

\begin{tabular}{|c|c|c|c|}
\hline atoms & distance & atoms & distance \\
\hline $\mathrm{C} 1-\mathrm{N} 2$ & $1.328(3)$ & N20-H20 & 0.8800 \\
\hline C1-N10 & $1.416(3)$ & $\mathrm{C} 21-\mathrm{C} 22$ & $1.512(3)$ \\
\hline C1-C6 & $1.417(3)$ & C21-H21A & 0.9900 \\
\hline $\mathrm{N} 2-\mathrm{C} 3$ & $1.351(3)$ & $\mathrm{C} 21-\mathrm{H} 21 \mathrm{~B}$ & 0.9900 \\
\hline $\mathrm{C} 3-\mathrm{C} 4$ & $1.393(3)$ & $\mathrm{C} 22-\mathrm{O} 23$ & $1.411(3)$ \\
\hline C3-C27 & $1.479(3)$ & $\mathrm{C} 22-\mathrm{H} 22 \mathrm{~A}$ & 0.9900 \\
\hline $\mathrm{C} 4-\mathrm{C} 5$ & $1.391(3)$ & $\mathrm{C} 22-\mathrm{H} 22 \mathrm{~B}$ & 0.9900 \\
\hline C4-C29 & $1.518(3)$ & $\mathrm{O} 23-\mathrm{C} 24$ & $1.422(4)$ \\
\hline C5-C6 & $1.377(3)$ & $\mathrm{C} 24-\mathrm{H} 24 \mathrm{~A}$ & 0.9800 \\
\hline $\mathrm{C} 5-\mathrm{H} 5$ & 0.9500 & C24-H24B & 0.9800 \\
\hline C6-C7 & $1.496(3)$ & C24-H24C & 0.9800 \\
\hline $\mathrm{C} 7-\mathrm{C} 8$ & $1.517(3)$ & $\mathrm{C} 25-\mathrm{N} 26$ & $1.152(3)$ \\
\hline C7-H7A & 0.9900 & $\mathrm{C} 27-\mathrm{O} 28$ & $1.214(3)$ \\
\hline C7-H7B & 0.9900 & $\mathrm{C} 27-\mathrm{H} 27$ & 0.9500 \\
\hline C8-C9 & $1.512(3)$ & $\mathrm{C} 29-\mathrm{N} 30$ & $1.466(3)$ \\
\hline C8-H8A & 0.9900 & C29-H29A & 0.9900 \\
\hline C8-H8B & 0.9900 & C29-H29B & 0.9900 \\
\hline C9-N10 & $1.488(3)$ & N30-C31 & $1.347(3)$ \\
\hline C9-H9A & 0.9900 & N30-C36 & $1.464(3)$ \\
\hline C9-H9B & 0.9900 & C31-O32 & $1.238(3)$ \\
\hline N10-C11 & $1.412(3)$ & C31-C33 & $1.504(4)$ \\
\hline C11-O12 & $1.222(3)$ & C33-N34 & $1.451(4)$ \\
\hline C11-N13 & $1.363(3)$ & C33-H33 A & 0.9900 \\
\hline N13-C14 & $1.397(3)$ & C33-H33B & 0.9900 \\
\hline N13-H13 & 0.8800 & N34-C35 & $1.445(4)$ \\
\hline C14-N15 & $1.354(3)$ & N34-C37 & $1.457(4)$ \\
\hline C14-C19 & $1.385(3)$ & C35-C36 & $1.510(4)$ \\
\hline $\mathrm{N} 15-\mathrm{C} 16$ & $1.329(3)$ & C $35-\mathrm{H} 35 \mathrm{~A}$ & 0.9900 \\
\hline C16-C17 & $1.391(3)$ & C $35-\mathrm{H} 35 \mathrm{~B}$ & 0.9900 \\
\hline C16-H16 & 0.9500 & С36-H36A & 0.9900 \\
\hline C17-C18 & $1.419(3)$ & С $36-\mathrm{H} 36 \mathrm{~B}$ & 0.9900 \\
\hline $\mathrm{C} 17-\mathrm{C} 25$ & $1.431(3)$ & C37-H37A & 0.9800 \\
\hline C18-N20 & $1.356(3)$ & C37-H37B & 0.9800 \\
\hline $\mathrm{C} 18-\mathrm{C} 19$ & $1.402(3)$ & C37-H37C & 0.9800 \\
\hline C19-H19 & 0.9500 & O38-H38B & 0.9002 \\
\hline N20-C21 & $1.454(3)$ & O38-H38A & 0.9001 \\
\hline
\end{tabular}

Bond lengths in $\AA$. Estimated standard deviations of refined parameters given in parentheses. Symmetry transformations used to generate equivalent atoms: n.a. 
Table S10 Anisotropic displacement parameters for compound 84

\begin{tabular}{|c|c|c|c|c|c|c|}
\hline atom & U11 & $\mathrm{U} 22$ & U33 & $\mathrm{U} 23$ & U13 & U12 \\
\hline $\mathrm{C} 1$ & $0.0162(11)$ & $0.0170(11)$ & $0.0190(11)$ & $0.0014(8)$ & $0.0034(9)$ & $0.0023(9)$ \\
\hline $\mathrm{N} 2$ & $0.0202(10)$ & $0.0178(9)$ & $0.0195(9)$ & $0.0008(7)$ & $0.0054(8)$ & $0.0008(8)$ \\
\hline $\mathrm{C} 3$ & $0.0190(12)$ & $0.0182(11)$ & $0.0209(11)$ & $0.0007(9)$ & $0.0033(9)$ & $0.0009(9)$ \\
\hline $\mathrm{C} 4$ & $0.0189(12)$ & $0.0198(11)$ & $0.0224(11)$ & $0.0022(9)$ & $0.0038(9)$ & $0.0004(9)$ \\
\hline C5 & $0.0193(12)$ & $0.0238(12)$ & $0.0218(12)$ & $0.0030(9)$ & $0.0072(9)$ & $0.0008(9)$ \\
\hline C6 & $0.0210(12)$ & $0.0180(11)$ & $0.0203(11)$ & $0.0020(9)$ & $0.0070(9)$ & $0.0012(9)$ \\
\hline $\mathrm{C} 7$ & $0.0224(13)$ & $0.0332(13)$ & $0.0188(11)$ & $-0.0006(10)$ & $0.0067(10)$ & $-0.0013(10)$ \\
\hline $\mathrm{C} 8$ & $0.0247(13)$ & $0.0253(12)$ & $0.0193(11)$ & $-0.0009(9)$ & $0.0075(10)$ & $-0.0007(10)$ \\
\hline C9 & $0.0244(13)$ & $0.0261(12)$ & $0.0176(11)$ & $-0.0015(9)$ & $0.0046(9)$ & $-0.0026(10)$ \\
\hline N10 & $0.0170(10)$ & $0.0224(10)$ & $0.0169(9)$ & $-0.0001(7)$ & $0.0050(7)$ & $-0.0010(8)$ \\
\hline C11 & $0.0187(12)$ & $0.0180(11)$ & $0.0229(12)$ & $0.0029(9)$ & $0.0046(10)$ & $0.0014(9)$ \\
\hline $\mathrm{O} 12$ & $0.0201(9)$ & $0.0290(9)$ & $0.0261(8)$ & $-0.0034(7)$ & $0.0052(7)$ & $-0.0033(7)$ \\
\hline N13 & $0.0158(10)$ & $0.0259(10)$ & $0.0227(10)$ & $-0.0002(8)$ & $0.0047(8)$ & $-0.0032(8)$ \\
\hline $\mathrm{C} 14$ & $0.0188(12)$ & $0.0202(11)$ & $0.0238(12)$ & $0.0045(9)$ & $0.0073(9)$ & $0.0030(9)$ \\
\hline N15 & $0.0200(10)$ & $0.0251(10)$ & $0.0212(10)$ & $0.0015(8)$ & $0.0051(8)$ & $0.0007(8)$ \\
\hline $\mathrm{C} 16$ & $0.0235(12)$ & $0.0239(12)$ & $0.0189(11)$ & $0.0013(9)$ & $0.0046(9)$ & $0.0015(10)$ \\
\hline $\mathrm{C} 17$ & $0.0204(12)$ & $0.0215(11)$ & $0.0215(11)$ & $0.0049(9)$ & $0.0067(9)$ & $0.0032(10)$ \\
\hline C18 & $0.0155(11)$ & $0.0195(11)$ & $0.0235(11)$ & $0.0039(9)$ & $0.0039(9)$ & $0.0019(9)$ \\
\hline C19 & $0.0195(12)$ & $0.0234(12)$ & $0.0212(11)$ & $0.0007(9)$ & $0.0055(9)$ & $0.0003(9)$ \\
\hline $\mathrm{N} 20$ & $0.0177(10)$ & $0.0312(11)$ & $0.0220(10)$ & $0.0009(8)$ & $0.0067(8)$ & $-0.0014(9)$ \\
\hline $\mathrm{C} 21$ & $0.0199(12)$ & $0.0306(13)$ & $0.0245(12)$ & $-0.0006(10)$ & $0.0055(10)$ & $-0.0018(10)$ \\
\hline $\mathrm{C} 22$ & $0.0258(13)$ & $0.0391(15)$ & $0.0235(12)$ & $0.0007(10)$ & $0.0063(10)$ & $0.0013(11)$ \\
\hline $\mathrm{O} 23$ & $0.0312(11)$ & $0.0597(13)$ & $0.0462(12)$ & $0.0182(10)$ & $0.0112(9)$ & $0.0174(10)$ \\
\hline $\mathrm{C} 24$ & $0.062(2)$ & $0.078(3)$ & $0.0497(19)$ & $0.0254(18)$ & $0.0201(17)$ & $0.037(2)$ \\
\hline $\mathrm{C} 25$ & $0.0220(12)$ & $0.0223(12)$ & $0.0223(12)$ & $0.0019(9)$ & $0.0059(10)$ & $0.0013(10)$ \\
\hline N26 & $0.0307(12)$ & $0.0333(12)$ & $0.0287(11)$ & $0.0015(9)$ & $0.0103(10)$ & $0.0028(9)$ \\
\hline $\mathrm{C} 27$ & $0.0235(13)$ & $0.0235(12)$ & $0.0212(12)$ & $-0.0023(9)$ & $0.0073(10)$ & $0.0002(10)$ \\
\hline $\mathrm{O} 28$ & $0.0300(9)$ & $0.0299(9)$ & $0.0204(8)$ & $-0.0031(7)$ & $0.0046(7)$ & $-0.0009(8)$ \\
\hline $\mathrm{C} 29$ & $0.0178(12)$ & $0.0310(13)$ & $0.0228(12)$ & $-0.0013(10)$ & $0.0042(9)$ & $-0.0005(10)$ \\
\hline N30 & $0.0167(10)$ & $0.0392(12)$ & $0.0252(10)$ & $0.0016(9)$ & $0.0063(8)$ & $-0.0042(9)$ \\
\hline $\mathrm{C} 31$ & $0.0188(12)$ & $0.0373(15)$ & $0.0250(12)$ & $-0.0072(10)$ & $0.0011(10)$ & $-0.0020(11)$ \\
\hline $\mathrm{O} 32$ & $0.0245(9)$ & $0.0338(10)$ & $0.0371(10)$ & $-0.0003(8)$ & $0.0107(8)$ & $-0.0025(8)$ \\
\hline C33 & $0.0240(14)$ & $0.0479(16)$ & $0.0302(14)$ & $-0.0054(12)$ & $0.0077(11)$ & $-0.0025(12)$ \\
\hline N34 & $0.0241(11)$ & $0.0564(15)$ & $0.0296(12)$ & $0.0020(10)$ & $0.0084(9)$ & $-0.0017(11)$ \\
\hline $\mathrm{C} 35$ & $0.0334(16)$ & $0.0566(19)$ & $0.0378(16)$ & $0.0093(13)$ & $0.0145(13)$ & $-0.0045(14)$ \\
\hline $\mathrm{C} 36$ & $0.0294(15)$ & $0.0408(16)$ & $0.0391(15)$ & $0.0103(12)$ & $0.0095(12)$ & $-0.0050(12)$ \\
\hline C37 & $0.0274(15)$ & $0.080(2)$ & $0.0319(15)$ & $-0.0034(15)$ & $0.0115(12)$ & $-0.0023(15)$ \\
\hline $\mathrm{O} 38$ & $0.0733(17)$ & $0.0559(14)$ & $0.0768(17)$ & $0.0176(12)$ & $0.0409(14)$ & $0.0213(13)$ \\
\hline
\end{tabular}

Atomic displacement parameters in $\AA^{2}$. 
Table S11 Torsion angles for compound 84

\begin{tabular}{|c|c|c|c|}
\hline atoms & angle & atoms & angle \\
\hline $\mathrm{N} 10-\mathrm{C} 1-\mathrm{N} 2-\mathrm{C} 3$ & $176.20(19)$ & N15-C16-C17-C18 & $-0.2(4)$ \\
\hline C6-C1-N2-C3 & $-2.0(3)$ & N15-C16-C17-C25 & $-178.8(2)$ \\
\hline $\mathrm{C} 1-\mathrm{N} 2-\mathrm{C} 3-\mathrm{C} 4$ & $-0.8(3)$ & C16-C17-C18-N20 & $-179.4(2)$ \\
\hline $\mathrm{C} 1-\mathrm{N} 2-\mathrm{C} 3-\mathrm{C} 27$ & $-179.69(19)$ & $\mathrm{C} 25-\mathrm{C} 17-\mathrm{C} 18-\mathrm{N} 20$ & $-0.8(3)$ \\
\hline $\mathrm{N} 2-\mathrm{C} 3-\mathrm{C} 4-\mathrm{C} 5$ & $2.4(3)$ & C16-C17-C18-C19 & $0.4(3)$ \\
\hline $\mathrm{C} 27-\mathrm{C} 3-\mathrm{C} 4-\mathrm{C} 5$ & $-178.8(2)$ & C25-C17-C18-C19 & $179.0(2)$ \\
\hline N2-C3-C4-C29 & $-176.3(2)$ & N15-C14-C19-C18 & $-0.1(3)$ \\
\hline $\mathrm{C} 27-\mathrm{C} 3-\mathrm{C} 4-\mathrm{C} 29$ & $2.5(4)$ & N13-C14-C19-C18 & $-179.3(2)$ \\
\hline C3-C4-C5-C6 & $-1.2(3)$ & N20-C18-C19-C14 & $179.5(2)$ \\
\hline C29-C4-C5-C6 & $177.4(2)$ & C17-C18-C19-C14 & $-0.3(3)$ \\
\hline $\mathrm{C} 4-\mathrm{C} 5-\mathrm{C} 6-\mathrm{C} 1$ & $-1.3(3)$ & C19-C18-N20-C21 & $-0.4(3)$ \\
\hline $\mathrm{C} 4-\mathrm{C} 5-\mathrm{C} 6-\mathrm{C} 7$ & $-178.1(2)$ & C17-C18-N20-C21 & $179.4(2)$ \\
\hline $\mathrm{N} 2-\mathrm{C} 1-\mathrm{C} 6-\mathrm{C} 5$ & $3.0(3)$ & C18-N20-C21-C22 & $-76.9(3)$ \\
\hline N10-C1-C6-C5 & $-175.2(2)$ & $\mathrm{N} 20-\mathrm{C} 21-\mathrm{C} 22-\mathrm{O} 23$ & $-78.0(3)$ \\
\hline N2-C1-C6-C7 & $179.8(2)$ & $\mathrm{C} 21-\mathrm{C} 22-\mathrm{O} 23-\mathrm{C} 24$ & $174.7(3)$ \\
\hline N10-C1-C6-C7 & $1.6(3)$ & C16-C17-C25-N26 & $-15(41)$ \\
\hline C5-C6-C7-C8 & $148.2(2)$ & C18-C17-C25-N26 & $166(100)$ \\
\hline C1-C6-C7-C8 & $-28.4(3)$ & N2-C3-C27-O28 & $-179.7(2)$ \\
\hline C6-C7-C8-C9 & $55.8(2)$ & $\mathrm{C} 4-\mathrm{C} 3-\mathrm{C} 27-\mathrm{O} 28$ & $1.4(4)$ \\
\hline C7-C8-C9-N10 & $-59.4(2)$ & $\mathrm{C} 5-\mathrm{C} 4-\mathrm{C} 29-\mathrm{N} 30$ & $-11.2(3)$ \\
\hline N2-C1-N10-C11 & $1.1(3)$ & C3-C4-C29-N30 & $167.4(2)$ \\
\hline C6-C1-N10-C11 & $179.4(2)$ & C4-C29-N30-C31 & $-84.8(3)$ \\
\hline N2-C1-N10-C9 & $178.34(19)$ & C4-C29-N30-C36 & $97.1(3)$ \\
\hline C6-C1-N10-C9 & $-3.4(3)$ & C36-N30-C31-O32 & $-179.8(2)$ \\
\hline C8-C9-N10-C11 & $-149.6(2)$ & C29-N30-C31-O32 & $2.1(3)$ \\
\hline C8-C9-N10-C1 & $32.8(3)$ & C36-N30-C31-C33 & $-1.8(3)$ \\
\hline C1-N10-C11-O12 & $-179.5(2)$ & C29-N30-C31-C33 & $-179.8(2)$ \\
\hline C9-N10-C11-O12 & $3.2(3)$ & O32-C31-C33-N34 & $-164.3(2)$ \\
\hline C1-N10-C11-N13 & $0.9(3)$ & N30-C31-C33-N34 & $17.6(3)$ \\
\hline C9-N10-C11-N13 & $-176.45(19)$ & C31-C33-N34-C35 & $-50.5(3)$ \\
\hline O12-C11-N13-C14 & $2.2(4)$ & C31-C33-N34-C37 & $-173.7(2)$ \\
\hline N10-C11-N13-C14 & $-178.2(2)$ & C33-N34-C35-C36 & $67.6(3)$ \\
\hline C11-N13-C14-N15 & $176.2(2)$ & C37-N34-C35-C36 & $-170.7(2)$ \\
\hline C11-N13-C14-C19 & $-4.5(4)$ & C31-N30-C36-C35 & $18.2(3)$ \\
\hline C19-C14-N15-C16 & $0.3(3)$ & C29-N30-C36-C35 & $-163.7(2)$ \\
\hline N13-C14-N15-C16 & 179.60(19) & N34-C35-C36-N30 & $-50.5(3)$ \\
\hline C14-N15-C16-C17 & $-0.2(3)$ & & \\
\hline
\end{tabular}

Torsion angles in ${ }^{\circ}$. Symmetry transformations used to generate equivalent atoms: n.a. 
Table S12 Hydrogen bonds present within the compound 84 structure

$\begin{array}{lllll}\mathrm{D}-\mathrm{H} \cdots \mathrm{A} & \mathrm{d}(\mathrm{D}-\mathrm{H}) & \mathrm{d}(\mathrm{H} \cdots \mathrm{A}) & \mathrm{d}(\mathrm{D} \cdots \mathrm{A}) & <(\mathrm{DHA}) \\ \mathrm{N} 13-\mathrm{H} 13-\mathrm{N} 2 & 0.88 & 1.87 & 2.601(3) & 140.0 \\ \mathrm{~N} 20-\mathrm{H} 20-\mathrm{O} 32 \# 1 & 0.88 & 2.07 & 2.868(3) & 149.7 \\ \text { O38-H38B-O23\#1 } & 0.90 & 1.94 & 2.841(3) & 175.9 \\ \text { O38-H38A-O32 } & 0.90 & 1.97 & 2.859(3) & 170.3\end{array}$

Distances in $\AA$, angles in ${ }^{\circ}$. Symmetry transformations used to generate equivalent atoms:

$\# 1-x+3 / 2,-y+3 / 2,-z+2$ 


\section{Suporting information references}

1 Bairoch, A.; Boeckmann, B. The SWISS-PROT protein sequence data bank: current status. Nucleic Acids Res. 1994, 22, 3578-3580.

2 Notredame, C.; Higgins, D., G.; Heringa, J. T-Coffee: A novel method for fast and accurate multiple sequence alignment. J. Mol. Biol. 2000, 302, 205-217.

3 Vriend, G. WHAT IF: A molecular modeling and drug design program. J. Mol. Graph. 1990, 8, 52-56.

4 Mohamadi, F.; Richards, N. G. J.; Guida, W. C.; Liskamp, R.; Lipton, M.; Caufield, C.; Chang, G.; Hendrickson, T.; Still, W. C. MacroModel - An integrated software system for modeling organic and bioorganic molecules using molecular mechanics. J. Comput. Chem. 1990, 11, 440-467.

5 Stiefl, N.; Gedeck, P.; Chin, D.; Hunt, P.; Lindvall, M.; Spiegel, K.; Springer, C.; Biller, S.; Buenemann, C.; Kanazawa, T.; Kato, M.; Lewis, R.; Martin, E.; Polyakov, V.; Tommasi, R.; van Drie, J.; Vash, B.; Whitehead, L.; Xu, Y.; Abagyan, R.; Raush, E.; Totrov, M. FOCUS - Development of a Global Communication and Modeling Platform for Applied and Computational Medicinal Chemists. J. Chem. Inf. Model. 2015, 55, 896-908.

6 Wilcken, R. and Ertl, P. Manuscript in preparation.

7 Derome, A.; Williamson, M. Rapid Pulsing Artifacts in Double-Quantum-Filtered COSY. J. Magn. Reson. 1990, $88,177-185$.

8 Hwang, T. L.; Shaka, A. J. Cross Relaxation without TOCSY: Transverse Rotating-Frame Overhauser Effect Spectroscopy. J. Am. Chem. Soc. 1992, 114, 3157-3159.

9 Bax, A.; Summers, M. F. ${ }^{1} \mathrm{H}$ and ${ }^{13} \mathrm{C}$ Assignments from Sensitivity-Enhanced Detection of Heteronuclear Multiple-Bond Connectivity by 2D Multiple Quantum NMR. J. Am. Chem. Soc. 1986, 108, 2093-2094.

10 Blanchard, K. C.; Dearborn, E. H.; Lasagna, L. C.; Buhle, E. L. The Antidiuretic Activity of Some Organic Acids. Bull. Johns Hopkins Hosp. 1952, 91, 330-340.

11 Further details of the synthetic sequences used to prepare these analogues can be found in: Buschmann, N.; Fairhurst, R. A.; Furet, P.; Knöpfel, T.; Leblanc, C.; Mah, R.; Nimsgern, P.; Ripoche, S.; Liao, L.; Xiong, J.; Zhao, X.; Han, B.; Wang, C. Ring-fused bicyclic pyridyl derivatives as FGFR4 inhibitors. PCT patent WO 2015/059668.; Buschmann, N.; Fairhurst, R. A.; Furet, P.; Knöpfel, T.; Leblanc, C.; Mah, R. Formylated Nheterocyclic derivatives as FGFR4 inhibitors. PCT patent WO 2016/151499.

12 Niyaz, N. M.; Hunter, R.; Johnson, T. C.; Trullinger, T. K.; Brown, A. V.; Bryan, K. Insecticidal Substituted Azinyl Derivatives. U.S. Patent 0,093,486, 2009. 2-Aminopyridines were reacted with oxaly chloride to generate intermediates of the form shown below that were reacted with THNU's in DCM in the presence of Hünig's base at room temperature to generate the corresponding ureas in modest yields $(<30 \%)$. 


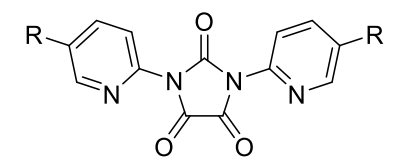

13 Lesca, E.; Lammens, A.; Huber R.; Augustin M. Structural Analysis of the Human Fibroblast Growth Factor Receptor 4 Kinase. J. Mol. Biol., 2014, 426, 3744-3756.

$14 \mathrm{Kabsch}, \mathrm{W}$. Automatic processing of rotation diffraction data from crystals of initially unknown symmetry and cell constants. J. Appl. Crystallogr. 1993, 26, 795-800.

15 Winn, M. D.; Ballard, C. C.; Cowtan, K. D.; Dobson, E. J.; Emsley, P.; Evans, P. R.; Ke egan, R. M.; Krissinel, E. B.; Leslie, A. G. W.; McCoy, A.; McNicholas, S. J.; Murshudov, G. N.; Pannu, N. S.; Potterton, E. A.; Powell, H. R.; Read, R. J.; Vagin, A.; Wilson, K. S. Overview of the CCP4 suite and current developments. Acta. Cryst. D67 2011, 235-242.

16 Emsley, P.; Cowtan, K. Coot: model-building tools for molecular graphics. Acta Crystallogr., Sect. D. Biol. Crystallogr. 2004, 60, 2126-2132.

17 Vonrhein, C.; Flensburg, C.; Keller, P.; Sharff, A.; Smart, O.; Paciorek, W.; Womack, T.; Bricogne, G. Data processing and analysis with the autoPROC toolbox. Acta Cryst. D67, 2011, 293-302.

18 SMART V5.632. Bruker AXS Inc.. Madison, WI, USA.

19 SAINT V7.36A. Bruker AXS Inc.. Madison, WI, USA.

20 SADABS V2008/1; Bruker AXS Inc.; Madison, WI, USA.

21 SHELXTL V6.12. Bruker AXS Inc.. Madison, WI, USA.

22 Allen, F. H.; Kennard, O.; Watson, D. G.; Brammer, L.; Orpen, A. G.; Taylor, R. Tables of Bond Lengths determined by X-Ray and Neutron Diffraction. Part 1, Bond Lengths in Organic Compounds. J. Chem. Soc. Perkin Trans 2, 1987, S1-S19.

23 Spek, A. L. Single-crystal structure validation with the program PLATON. J. Appl. Cryst. 2003, 36, 7-13. 